\title{
Closing the nutrient loops in (peri-)urban farming systems through composting
}

Abebe Nigussie 


\section{Thesis committee}

\section{Promotors}

Prof. Dr. Thomas W. Kuyper

Personal chair at the Department of Soil Quality

Wageningen University, The Netherlands

Prof. Dr. A. de Neergaard

Professor of Soil Fertility

Department of Plant and Environmental Sciences, University of Copenhagen, Denmark

\section{Co-promotor}

Dr. S. Bruun

Associate professor at the Department of Plant and Environmental Sciences

University of Copenhagen, Denmark

\section{Other members of the committee}

Prof. Dr. Ir. G. Zeeman, Wageningen University, The Netherlands

Dr. J. Magid, Copenhagen University, Denmark

Dr. M.L. Cayuela, Spanish National Research Council, Murcia, Spain

Dr. Ir. C.L. van Beek, Alterra, Wageningen Environmental Research, The Netherlands

This research was conducted under the auspices of the PhD School of Science of the University of Copenhagen and the C.T. de Wit Graduate School for Production Ecology and Resource Conservation of Wageningen University under the Erasmus Mundus Joint Doctorate Program Agricultural Transformation by Innovation (AgTraIn). 


\title{
Closing the nutrient loops in (peri-)urban farming systems through composting
}

\author{
Abebe Nigussie
}

Thesis

submitted in fulfilment of the requirements for the joint degree of Doctor at Wageningen University and University of Copenhagen by the authority of the Rector Magnificus Prof. Dr. A.P.J. Mol, and Head of Ph.D School of Science, Prof. Dr. M. Pejrup in the presence of the

Thesis Committee appointed by the Academic Board, Wageningen University, and the Ph.D School of Science, University of Copenhagen

to be defended in public

on Tuesday 24 January 2017

at 13:30 in the Aula of Wageningen University 
Abebe Nigussie

Closing the nutrient loops in (peri-)urban farming systems through composting, 144 pages

PhD Thesis, Wageningen University, The Netherlands

Copenhagen University, Denmark (2017)

With references, summaries in English and Danish

DOI: $10.18174 / 395151$

ISBN: 978-94-6343-005-0 
To my parents and wife 


\section{CONTENTS}

Chapter 1 General introduction 1

Chapter 2 Agricultural waste utilisation strategies and demand for urban- 13 waste compost: Evidences from smallholder farmers in Ethiopia

Chapter 3 Vermicomposting as a technology for reducing nitrogen losses and 39 greenhouse gas emissions from small-scale composting

Chapter 4 Delayed addition of nitrogen-rich substrates during composting of municipal waste: Effects on nitrogen loss, greenhouse gas emissions and compost stability

Chapter 5 Earthworms change the quantity and composition of dissolved organic carbon and reduce greenhouse gas emissions during composting

Chapter 6 General discussion

References

Summary

Sammenfatning 


\section{CHAPTER 1}

\section{General introduction}

\section{Background}

Mineral fertilisers and organic amendments (e.g. crop residues, animal manure and compost) are used to improve soil fertility and maintain agricultural fields in a productive state. The addition of organic amendments has been shown to maintain soil organic matter content and thereby contribute to enhanced fertiliser use efficiency (Negassa et al., 2005). Despite these benefits, the use of mineral fertiliser is limited in many developing countries due to its high price (Kassie et al., 2009; Dercon and Christiaensen, 2011), whereas only a small number of farmers in these countries apply organic amendments on their croplands (Baudron et al., 2014; Valbuena et al., 2015). Only small fractions of animal manure and crop residues are retained on croplands due to the strong competition for agricultural waste for fuel and animal feed (Fig 1.1; Baudron et al., 2014), the low production of manure (Tittonell et al., 2005) and limited labour availability (Tittonell et al., 2005; Kassie et al., 2009; Baudron et al., 2014). Other biodegradable materials such as urban waste should therefore be considered as alternative sources for soil amendment.

A United Nations report indicates that slightly more than half (54\%) of the world's population live in cities, with that number expected to rise to $66 \%$ by 2050 (United Nations, 2014). The rapid growth of urban populations generates large amounts of waste. As a result, waste management has become a matter of widespread concern (Marshall and Farahbakhsh, 2013), especially in developing countries where the current practices of waste treatment and/or re-use of waste are insufficient (Fig 1.1). Over 80\% of urban waste is disposed of in landfills or local dumpsites due to the high costs associated with alternative waste management practices (Scarlat et al., 2010). In these countries, more than half of urban solid waste is biodegradable (Kasozi and von Blottnitz, 2010; Getahun et al., 2012a), indicating that bioconversion of urban waste into soil amendments (i.e., composting) is feasible. 


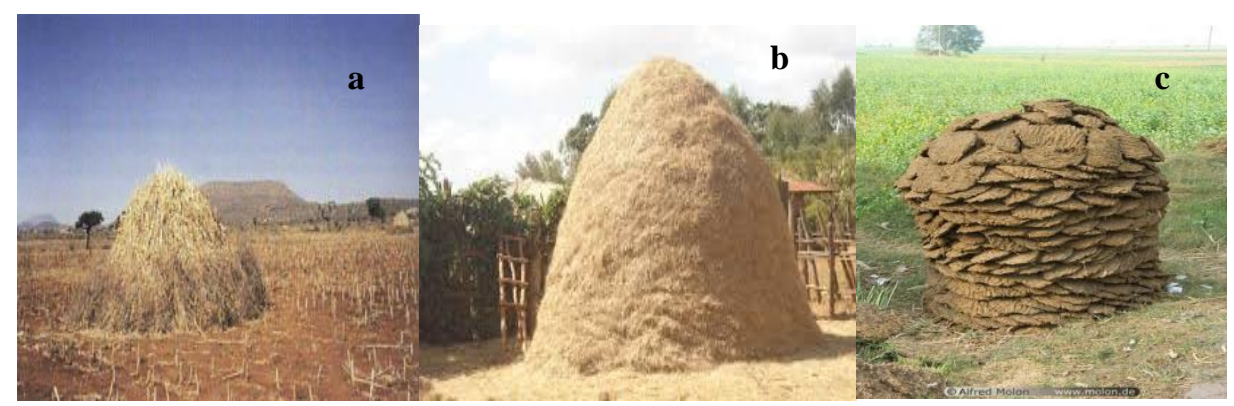

d

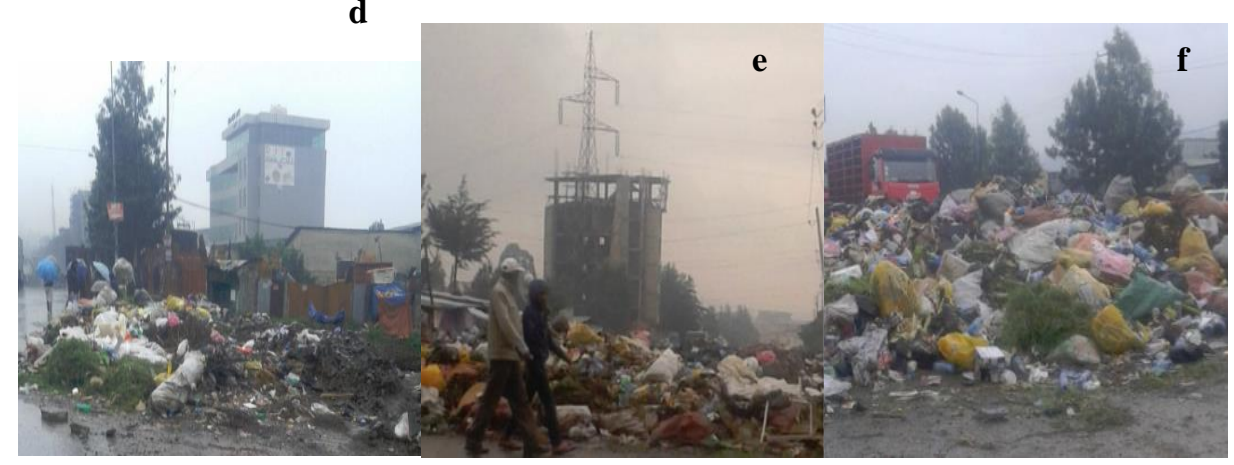

Figure 1.1. Stack of crop residues for fuel uses (a), animal feed (b); stack of animal manure (dung cake) for fuel uses (c); the current solid waste management problem in Addis Ababa, Ethiopia ( $-\mathrm{f}$ ).

Composting is a controlled and microbially mediated decomposition process that converts biodegradable waste into a stable product that is ultimately used as soil amendment. Urban waste composting can be used to recycle nutrients and close the rural-urban nutrient loop (Getahun et al., 2012b; Nigussie et al., 2015 (Chapter 2)).

Incorporation of urban-waste compost in soil improves soil chemical (Hargreaves et al., 2008), physical (Peltre et al., 2015) and biological properties (Garcia-Gil et al., 2004). However, urban-waste compost contains relatively low amounts of plant nutrients (especially nitrogen) compared to mineral fertiliser (Zhang et al., 2006) and hence is unable to meet crop nutrient requirements. Urban-waste compost, particularly in (sub)tropical countries has a low $\mathrm{N}$ content; hence, optimisation of urban-waste composting should place an emphasis on increasing the nitrogen concentration in the compost. A significant loss of gaseous nitrogen $(\mathrm{N})$ through ammonia volatilisation, nitrogen oxides $\left(\mathrm{NO}_{x}\right)$, nitrous oxide $\left(\mathrm{N}_{2} \mathrm{O}\right)$ or dinitrogen $\left(\mathrm{N}_{2}\right)$ occurs during composting of nitrogen-rich urban waste (Anderson et al., 2010). These high $\mathrm{N}$ losses reduce the fertilising value of compost and contribute to environmental problems (Hao et al., 2004). Therefore, it is also important to reduce the $\mathrm{N}$ losses during composting of $\mathrm{N}$-rich materials.

Greenhouse gas (GHG) emissions (mainly methane and nitrous oxide) from composting have repeatedly occurred in reports over the past two decades (Hao et al., 2004; Anderson, 2010). Methane $\left(\mathrm{CH}_{4}\right)$ is estimated to have a global warming potential 
(GWP) of 35 times that of $\mathrm{CO}_{2}$ over 100 years; whereas nitrous oxide $\left(\mathrm{N}_{2} \mathrm{O}\right)$ has a GWP of 298 times that of $\mathrm{CO}_{2}$ over 100 years (IPCC, 2013). Compost optimisation should therefore put emphasis on increasing or maintaining the nitrogen content of compost, reducing $\mathrm{N}$ losses and mitigating GHG emissions.

Several technologies, such as the addition of crop residues (Santos et al., 2016; Vu et al., 2015), the control of aeration rate (Chowdhury et al., 2014) and the control of pH (Awasthi et al., 2016) (section 1.2.), are suggested as ways of reducing $\mathrm{N}$ losses and GHG emissions from composting. However, most of these interventions are inadequate to fit easily within the broader small-scale farming systems in developing countries because these practices are expensive. There is therefore a need for more research to develop lowcost methods to mitigate $\mathrm{N}$ losses and GHG emissions from composting, while retaining the beneficial properties (fertilising value) of compost. This thesis aims to address this research demand.

Composting by earthworms (known as vermicomposting) is proposed in this thesis as a low-cost strategy for reducing N loss and GHG emissions (Chapter 3 and 4). I hypothesised that earthworms reduce GHG emissions from composting because they increase aeration in compost piles and influence $\mathrm{N}$ transformations through their interaction with associated microbes (Lazcano et al., 2008; Velasco-Velasco et al., 2011).

Another low-cost strategy for minimising $\mathrm{N}$ losses and GHG emissions from composting is to delay the addition of N-rich substrates. High temperatures $\left(>45^{\circ} \mathrm{C}\right)$ shift the $\mathrm{NH}_{4}{ }^{+}=\mathrm{NH}_{3}$ equilibrium towards ammonia (Pagans et al., 2006). The addition of N-rich substrate at the beginning of composting increases $\mathrm{N}$ losses due to the combination of labile $\mathrm{N}$ and high temperatures during the thermophilic phase, which is a conducive environment for ammonia volatilisation. The addition of N-rich substrate after the thermophilic phase is therefore proposed in this thesis (Chapter 5) as a way of reducing $\mathrm{N}$ losses from composting. The aim of this thesis is therefore to provide mechanistic insight into the effects of vermicomposting and the timing of substrate addition on $\mathrm{N}$ losses and GHG emissions from urban-waste composting.

There is extensive literature about the importance of urban-waste composting for soil fertility (Garcia-Gil et al., 2004) and crop production (Hargreaves et al., 2008). However, socio-cultural and economic perspectives of urban-waste compost receive less attention in developing countries, even though these issues should be studied prior to scaling up urban-waste composting into large-scale enterprises. This thesis (Chapter 2) also aims to address farmers' attitudes towards urban waste compost and to associate these with their livelihood strategies. 


\section{Nitrogen losses and GHG emissions from composting}

During composting, microorganisms consume oxygen and decompose organic materials, thereby generating heat, water vapour and carbon dioxide $\left(\mathrm{CO}_{2}\right)$. As organic matter decomposes, mineral nutrients such as nitrogen, phosphorus and sulphur are released. A significant amount of ammonia $\left(\mathrm{NH}_{3}\right), \mathrm{NO}_{x}$ and potent greenhouse gases (i.e., methane and nitrous oxide) are produced during composting as well.

There are three stages in the traditional (also known as thermophilic) composting process based on the temperatures in the compost pile (Fig. 1.2). The first stage is called the mesophilic phase (temperature $<45^{\circ} \mathrm{C}$ ). It is the initial phase of composting where the rapid breakdown of easily degradable compounds (i.e., sugar and starch) occurs. The heat produced during this stage raises temperatures to above $45{ }^{\circ} \mathrm{C}$ and leads to the second phase, called thermophilic composting. During the thermophilic stage, temperatures rise above $45{ }^{\circ} \mathrm{C}$ and the breakdown of proteins, fats, hemicellulose and cellulose occurs. The third stage is called the curing or maturation phase during which temperatures decrease to ambient temperature and more stable organic compounds are degraded at a low rate (Lazcano et al., 2008). The composting period and the length of each phase depends on the quality of the organic material (carbon, nitrogen, C:N ratio and other nutrients), moisture content, oxygen concentration (aeration) and size of the pile.

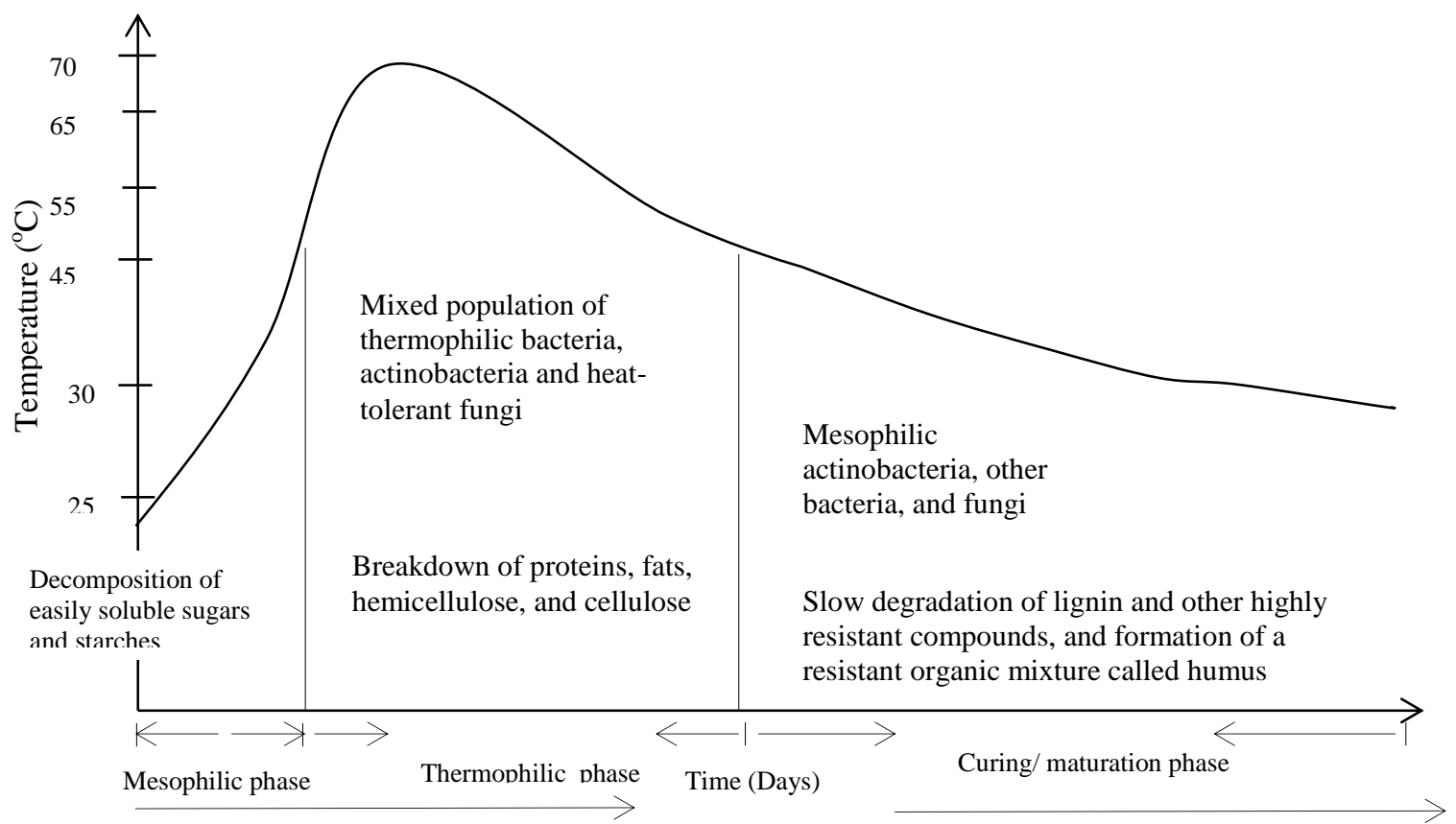

Figure 1.2. Temperature profile during the composting process and the different stages of composting 
Reducing nitrogen losses and GHG emissions are among the main challenges of the composting process because these losses reduce the fertilising value of compost and contribute to climate change. Ammonia volatilisation is the major $\mathrm{N}$ loss from compost and accounts for over 60\% of total N losses (Dias et al., 2009; Chowdhury et al., 2014). Ammonia volatilisation occurs mainly during the thermophilic phase of composting (Chowdhury et al., 2014). Similarly, Eklind et al. (2007) showed that higher temperatures (i.e., $67^{\circ} \mathrm{C}$ ) increase ammonia loss by more than $100 \%$ compared to lower temperatures (i.e., $40^{\circ} \mathrm{C}$ ). Many studies have shown that more than half of total $\mathrm{N}$ losses occur during the thermophilic stage of composting (Pagans et al., 2006; Dias et al., 2009).

Methane is produced in anoxic hotspots by methanogenic microbes while $\mathrm{N}_{2} \mathrm{O}$ is produced during nitrification in aerobic microsites and denitrification in anaerobic microsites (Hao et al., 2004). The total global warming potential ( $\mathrm{CO}_{2}$-equivalent) of composting processes reaches $80-110 \mathrm{~kg} \mathrm{CO}$-eq. $\mathrm{Mg}^{-1}$ fresh weight during garden waste composting (Anderson et al., 2010). Most $\mathrm{CH}_{4}$ emissions occur during the thermophilic stage of composting due to the coexistence of labile carbon compounds and anoxic microsites (Anderson et al., 2010; Chowdhury et al., 2014), and the activity of methanogens increases at high temperatures (Ermolaev et al., 2014). Chowdhury et al. (2014) and $\mathrm{Vu}$ et al. (2015) showed that more than $70 \%$ of $\mathrm{CH}_{4}$ production occurs during the thermophilic phase. On the other hand, $\mathrm{N}_{2} \mathrm{O}$ is emitted after the thermophilic stage because nitrifying and denitrifying bacteria are mesophilic (Hao et al., 2004; Vu et al., 2015).

Several strategies have been developed to reduce N losses and GHG emissions from composting. The increase in the $\mathrm{C}: \mathrm{N}$ ratio of the composting mixture is frequently used to reduce $\mathrm{N}$ losses and GHG emissions (Chowdhury et al., 2014; Wang et al., 2014). For example, the use of straw decreased total $\mathrm{N}$ loss by $33 \%$ from vegetable waste composting (Chapter 2) and by 27-30\% from manure composting (Vu et al., 2015; Sun et al., 2015). Similarly, high C:N materials such as sawdust, straw and biochar reduced $\mathrm{CH}_{4}$ emissions by $70-90 \%$ and $\mathrm{N}_{2} \mathrm{O}$ emissions by 37 - 43\% from composting, as noted by Jiang et al. (2011), Vu et al. (2015) and Chowdhury et al. (2014). Different mechanisms explain the effect of high C:N materials on reducing $\mathrm{N}$ losses and GHG emissions from composting. First, high C:N materials immobilise a significant amount of inorganic nitrogen and hence prevent ammonia volatilisation. Second, the bulkier nature of materials such as straw allows air movement through the compost pile, and influence temperature and moisture in compost pile and consequently affect $\mathrm{N}$ losses and GHG emissions (Bustamante et al., 2013; Chowdhury et al., 2014).

Aeration is another option for mitigating $\mathrm{N}$ losses and GHG emissions from composting because it reduces the presence of anaerobic hotspots in a composting pile. 
Excessive aeration, however, increases $\mathrm{N}$ loss via ammonia volatilisation (Chowdhury et al., 2014; Cook et al., 2015). Studies have shown that the total $\mathrm{N}$ loss can increase by over $88 \%$ during excessive aeration compared to optimal aeration (Chowdhury et al., 2014; Jiang et al., 2011). Similarly, Cook et al. (2015) observed that frequent turning of the compost pile (i.e., three times per week) more than doubled the total $\mathrm{N}$ losses compared with less frequent turning (i.e., once a week). Aeration reduces $\mathrm{CH}_{4}$ emissions from composting (Chowdhury et al., 2014; Jiang et al., 2011), but its effect on $\mathrm{N}_{2} \mathrm{O}$ emissions remains controversial. Studies have shown a stimulation effect (Jiang et al., 2011), inhibition effect (Shen et al., 2011) and no effect (Chowdhury et al., 2014) of aeration on $\mathrm{N}_{2} \mathrm{O}$ production. High $\mathrm{NO}_{3}{ }^{-}$production via nitrification - which leads to $\mathrm{N}_{2} \mathrm{O}$ production through nitrifier denitrification - explains the high $\mathrm{N}_{2} \mathrm{O}$ production with increasing aeration.

Controlling the $\mathrm{pH}$ using additives is another option for minimising ammonia volatilisation from composting because $\mathrm{pH}>9$ increases the production of ammonia (Pagans et al., 2006). The use of $\mathrm{NH}_{4}{ }^{+}$absorbents such as active carbon, biochar and zeolite has also been recommended to mitigate $\mathrm{N}$ losses from composting (Steiner et al., 2010; Chowdhury et al., 2014). However, these technologies are not included in this thesis because they are expensive.

Existing technologies to mitigate $\mathrm{N}$ losses and GHG emissions are difficult to scale out to farmer's conditions, particularly for smallholder farmers in developing countries. For instance, materials such as crop residues have competitive uses in smallholder farming systems. Over $85 \%$ of crop residues are used for feed and/or fuel in developing countries like Ethiopia (Baudron et al., 2014), making it difficult for smallholder farmers to produce high C:N ratio composting materials. Technologies such as controlling $\mathrm{pH}$ and aeration are expensive and require skill. Simple and low-cost strategies should therefore be investigated for smallholder farmers in developing countries.

\section{Vermicomposting as a low-cost strategy for reducing $\mathbf{N}$ losses and GHG emissions}

Vermicomposting is a composting process that involves both earthworms and associated microorganisms to decompose and stabilise organic materials (Munroe, 2007). During vermicomposting, earthworms fragment organic materials into smaller particles, and facilitate the further microbial decomposition process. There are an estimated 1800 earthworm species worldwide, but only a few of these species are used for vermicomposting. Epigeic earthworm species - earthworms that only feed on fresh, relatively un-decomposed litter - are used for vermicomposting, with Eisenia fetida and Dendrobaena veneta the most common earthworm species used for this purpose (Munroe, 2007). 
It is plausible that vermicomposting reduces $\mathrm{N}$ losses and GHG emissions from composting. First, earthworms improve air circulation through the continuous turning of organic materials, thereby maintaining aerobic conditions. Second, earthworms affect $\mathrm{N}$ cycling - mineralisation, immobilisation, nitrification and denitrification - through their interaction with associated microbes (Lazcano et al., 2008; Velasco-Velasco et al., 2011). Third, vermicomposting is a mesophilic process $\left(<30{ }^{\circ} \mathrm{C}\right)$, implying that ammonia volatilisation is less likely to occur because ammonia emissions rise with increasing temperature. The effects of earthworms on soil properties and GHG emissions (mainly $\mathrm{N}_{2} \mathrm{O}$ emissions) from soils are well documented (Lubbers et al., 2013), but earthworm effects on $\mathrm{N}$ losses and GHG emissions from composting are generally ignored and therefore need further investigation. In their report, Lubbers et al. (2013) showed that earthworms increased $\mathrm{N}_{2} \mathrm{O}$ emissions from soil. The substrate quality, earthworm species and earthworm density used for vermicomposting, however, differ from those in soil. Therefore it is impossible to extrapolate the results of soil experiments to vermicomposting systems.

Currently little is known about $\mathrm{N}$ losses and GHG emissions during vermicomposting (Lleó et al., 2013; Lim et al., 2016), and the literature is contradictory. These contradictions are probably explained by the different conditions of the experiments such as mineral $\mathrm{N}$ concentration, $\mathrm{C}$ quality, moisture content and earthworm density, all of which could influence $\mathrm{N}$ loss and GHG emissions from vermicomposting. For instance, mineral nitrogen and available $\mathrm{C}$ contents influence the denitrification processes in the earthworm gut of anecic earthworms (Lubbers et al., 2013). Earthworm density might influence aeration and subsequently influence GHG emissions. My thesis used a wide range of substrate qualities (i.e., C:N ratio, labile $\mathrm{C}$ sources such as glucose) and other factors (i.e., earthworm density, amount of input, and moisture) to clarify our understanding of the effects of earthworms on N losses and GHG emissions from composting.

\section{Timing of substrate addition as a low-cost strategy for reducing $\mathbf{N}$ losses}

Recently, N-rich substrates such as poultry manure have been applied during composting to increase the fertilising value of compost (Dias et al., 2009). The addition of more labile $\mathrm{N}$ materials at the beginning of composting results in ammonia volatilisation (Bryndum, 2014) due to the co-existence of a high concentration of $\mathrm{NH}_{4}^{+}$, easily mineralisable compounds and a high temperature. Delaying (splitting) the addition of an $\mathrm{N}$-rich substrate has therefore been studied in this thesis to reduce $\mathrm{N}$ losses from composting. During the split addition of an N-rich substrate, the first part is added at the beginning of composting to support the turnover of labile carbon. The remaining part is 
then added after the thermophilic phase to increase the $\mathrm{N}$ concentration in the compost (Dresbøll and Thorup-Kristensen, 2005). It is hypothesised that postponing the addition of an N-rich substrate reduces ammonia volatilisation because the majority of added $\mathrm{N}$ experience conditions that are less conducive to $\mathrm{NH}_{3}$ volatilisation. However, the effect of timing of an N-rich substrate addition on $\mathrm{N}$ losses under different substrate quality (i.e., bulking agent) is not yet known. Manure can contain weed seeds, and applying composted manure could raise a concern of spreading weeds unless the seeds are eradicated during composting. Hence, delayed addition of an N-rich substrate might be less efficient at eradicating weed seeds and producing stable compost because the newly added substrate has had less time to decompose. This thesis therefore evaluates the effect of delayed addition of an N-rich substrate on compost stability and sanitisation.

The timing of the addition of an N-rich substrate might also influence GHG emissions from composting. For instance, the addition of an N-rich substrate after the thermophilic phase might increase $\mathrm{N}_{2} \mathrm{O}$ emissions by increasing the bioavailability of mineral $\mathrm{N}$ for nitrifying and denitrifying bacteria. On the other hand, late addition of an $\mathrm{N}$-rich substrate could reduce $\mathrm{CH}_{4}$ production due to the low temperatures for methanogenic microbes. Furthermore, high $\mathrm{NH}_{4}{ }^{+}$concentrations during early addition might reduce methane oxidation in the thermophilic phase due to the enzymatic similarity between methane and ammonium oxidation (Hao et al., 2005; Wei et al., 2016). However, no studies have been conducted so far on the relationship between the timing of an N-rich substrate addition and GHG emissions from composting.

\section{Objectives}

Based on the above-mentioned research needs, the overall objective of this thesis is to provide a better understanding of existing waste management practices in developing countries and ensure sustainable crop production via the biotransformation of urban waste into a high-quality soil amendment. The specific objectives of the thesis are:

(i) to assess the current agricultural waste utilisation strategies and the demand for urban-waste compost among different farmer groups in Ethiopia (Chapter 2)

(ii) to evaluate the effectiveness of vermicomposting to mitigate $\mathrm{N}$ losses and GHG emissions during composting and produce a high-quality soil amendment, linking this effect with substrate quality (as assessed by $\mathrm{C}: \mathrm{N}$ ratio and the presence of a labile C pool) and variables (i.e. moisture content and earthworm density) (Chapter 3)

(iii) to evaluate the potential of delayed addition of $\mathrm{N}$-rich substrates to reduce $\mathrm{N}$ losses and GHG emissions during composting and compost stability (Chapter 4). 
(iv) to evaluate the effect of earthworms on dissolved organic carbon quantity and composition of the compost, linking this effect to the initial substrate quality and feeding ratio (Chapter 5)

\section{Thesis outline}

This thesis consists of six chapters: a general introduction (Chapter 1), four research chapters (Chapter 2, 3, 4 and 5) and a general discussion (Chapter 6).

In developing countries, only small fractions of agricultural waste are retained on croplands as soil amendment. Therefore, the research outlined in Chapter 2 was undertaken (i) to investigate current agricultural waste utilisation strategies among different farmer groups and (ii) to identify the socio-economic factors influencing farmers' decision to use agricultural waste as soil amendments. The demand for urban waste compost among different farmer groups was also assessed. Approximately 220 urban and peri-urban farmers in Addis Ababa, Ethiopia, were involved in this study. Group discussions and a standardised semi-structured questionnaire were used. On the basis of multivariate analysis the farmers were then classified into different livelihood groups. Field measurements were carried out to quantify partial nutrient flows and the percentages of agricultural waste allocated for different purposes (i.e., feed, fuel, trade etc.). The contingency valuation method (CVM) was used to determine compost demand.

In Chapter 2, urban wastes are suggested as alternative sources of soil amendments in developing countries because agricultural waste is used mainly for fuel and animal feed. Chapters 3, 4 and 5 therefore describe different strategies to optimise the agronomic and environmental benefits of urban-waste composting. More specifically, these chapters address the two common composting methods (i.e., thermophilic composting and vermicomposting) and their effect on $\mathrm{N}$ losses, GHG emissions and compost quality.

There is considerable literature available about $\mathrm{N}$ losses and GHG emissions from the thermophilic composting method, but little is known about the effectiveness of vermicomposting to reduce $\mathrm{N}$ losses and GHG emissions compared with thermophilic composting. In Chapter 3, the effectiveness of vermicomposting at reducing $\mathrm{N}$ loss and GHG emissions is addressed using different variables such as $\mathrm{C}: \mathrm{N}$ ratio, labile $\mathrm{C}$ sources (i.e., glucose), moisture content and earthworm density. This chapter describes three independent experiments that were performed. The first experiment was conducted to test the effectiveness of vermicomposting to reduce $\mathrm{N}$ loss and GHG emissions from materials with different $\mathrm{C}: \mathrm{N}$ ratios. The second experiment tested the effect of earthworm density on GHG emissions from vermicomposting. The third experiment was 
performed to test the effect of moisture and addition of glucose on GHG emissions from vermicomposting. To test these objectives, kitchen waste was used as composting material. All the experiments were conducted in small-scale composting reactors, and the experiments lasted for 45 days.

Chapter 4 describes the effect of the timing of addition of an N-rich substrate on $\mathrm{N}$ loss and GHG emissions from composting. To test this effect, a medium-scale experiment was conducted for 90 days in $1 \mathrm{~m} \times 1 \mathrm{~m} \times 1 \mathrm{~m}$ boxes made of wood. Poultry manure (N-rich substrate) was applied in three different ways: (i) all poultry manure was applied at the beginning of composting, (ii) $80 \%$ of poultry manure was applied at the start of composting and the remaining $20 \%$ added after the thermophilic phase, or (iii) $20 \%$ of poultry manure was applied at the start of composting and the remaining $80 \%$ was added after the thermophilic phase. Total $\mathrm{N}$ loss was estimated using a massbalance, and the $\mathrm{CO}_{2}, \mathrm{~N}_{2} \mathrm{O}$ and $\mathrm{CH}_{4}$ emissions were measured to quantify the GHG budgets. To test the effect of split addition of N-rich substrate on sanitation, seeds from four weed species were put in small nylon mesh bags and added to the compost pile. At the end of the composting experiment, the nylon bags were retrieved and the seeds tested for germination. The incubation experiment was conducted for 90 days and different indices were used to test for the effect of the timing of N-rich substrate addition on compost stability.

In my previous studies (Chapter 3), I noted that earthworms increased $\mathrm{CO}_{2}$ emissions, and the higher $\mathrm{CO}_{2}$ emissions indicated a higher degree of stabilisation. Therefore, I initiated Chapter 5 to link the effect of earthworms on $\mathrm{CO}_{2}$ emissions with dissolved organic carbon (DOC) quantity and its composition (humic acid, fulvic acid, hydrophobic neutral, and hydrophilic compounds) - which is a recently proposed indicator of compost stability. Chapter 5 also deals with the effect of feeding ratio on compost stability and GHG emissions from vermicomposting. To address these objectives a laboratory-scale vermicomposting was conducted for 60 days using garden waste.

In Chapter 6, I argue that reliance solely on agricultural waste to increase soil fertility and sustain crop production is problematic, especially in developing countries. I therefore suggest that biodegradable urban waste should be considered as alternative resource for sustainable agricultural production in developing countries. The chapter contains a synthesis of the merits and demerits of the composting technologies that are suggested in this thesis to mitigate $\mathrm{N}$ losses and GHG emissions and ends with the conclusions and policy implications of the findings from this thesis. Finally, this chapter suggests future research directions. 


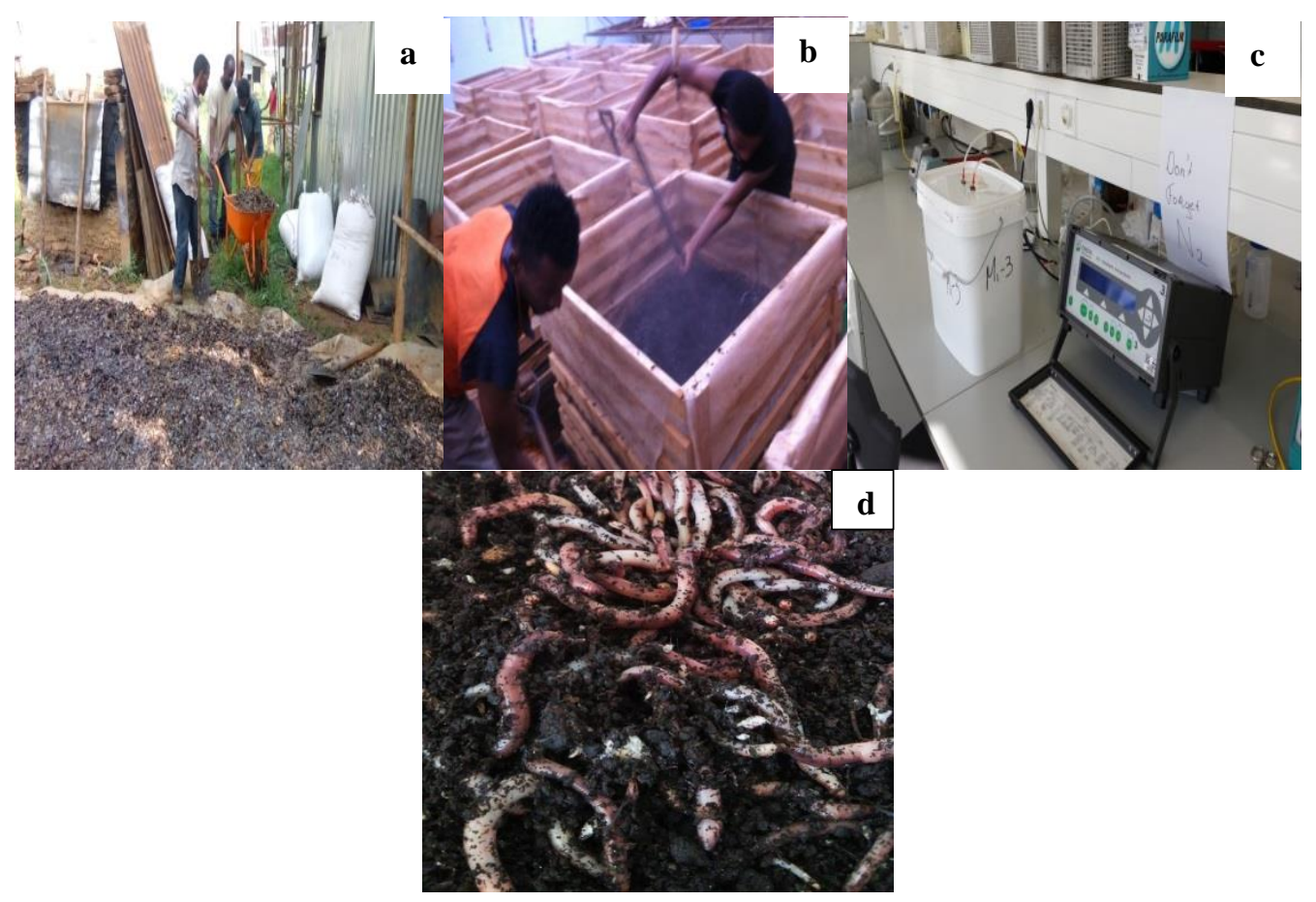

Figure 1.3. Mixing of the composting materials in Ethiopia, Jimma (a), turning of the composting piles (b), taking gas samples from small-scale vermicomposting reactors (c), the earthworms (d). 



\section{CHAPTER 2}

\section{Agricultural waste utilisation strategies and demand for urban-waste compost: Evidences from smallholder farmers in Ethiopia}

This chapter is published as:

Nigussie, A., Kuyper, T.W., de Neergaard, A. (2015). Agricultural waste utilisation strategies and demand for urban-waste compost: Evidence from smallholder farmers in Ethiopia. Waste Management 44, 82 - 93. 


\title{
Agricultural waste utilisation strategies and demand for urban-waste compost: Evidences from smallholder farmers in Ethiopia
}

\begin{abstract}
The use of agricultural waste for soil amendment is limited in developing countries. Competition between fuel and feed is the major cause for the insufficient application of agricultural waste on cropland. The aims of this study were therefore (i) to investigate variation in agricultural-waste allocation between groups of farmers with different livelihood strategies and link this allocation with the nutrient balances of their production systems, (ii) to identify farm characteristics that influence utilisation of agricultural waste for soil amendment, and (iii) to assess demand for urban-waste compost. A total of 220 farmers were selected randomly and interviewed using standardised semi-structured questionnaires. Four groups of farmers, namely (i) field crop farmers, (ii) vegetable producers, (iii) ornamental-plant growers, and (iv) farmers practising mixed farming, were identified using categorical principal component and two-step cluster analyses. Field crop farmers produced the largest quantity of agricultural waste, but they allocated $80 \%$ of manure to fuel and $85 \%$ of crop residues to feed. Only $<10 \%$ of manure and crop residues were applied on soils. Farmers also sold manure and crop residues, and this generated 5-10\% of their annual income. Vegetable and ornamental-plant growers allocated over $40 \%$ of manure and crop residues to soil amendment. Hence, nutrient balances were less negative in vegetable production systems. Education, farm size, land tenure and access to extension services were the variables that impeded allocation of agricultural waste to soil amendment. Replacement of fuel and feed through sustainable means is a viable option for soil fertility management. Urban-waste compost should also be used as alternative option for soil amendment. Our results showed variation in compost demand between farmers. Education, landownership, experience with compost and access to extension services explained variation in compost demand. We also demonstrated that labour availability should be used to estimate compost demand beside cash.
\end{abstract}

Keywords: animal manure, crop residue, compost, livelihood strategy, municipal waste 


\section{Introduction}

Urban and peri-urban agroecosystems are common in many countries, and they are often characterised by a surplus nutrient balance due to the intensive use of fertilisers and heavy irrigation with waste water (Khai et al., 2007; Wang et al., 2008; Diogo et al., 2010; Abdulkadir et al., 2013). In contrast, some studies showed negative nutrient balances and hence declining soil fertility in urban and peri-urban farming systems (Tewodros et al., 2007). Mineral fertilisers have been used to improve and maintain soil fertility and crop production; however, this is a challenge for many smallholder farmers because mineral fertilisers are expensive (Kassie et al., 2009; Dercon and Christiaensen, 2011). Hence, the integration of mineral fertilisers with organic amendments (e.g. animal manure and compost) has been recommended to increase crop production (Negassa et al., 2005). Organic amendments could also increase or maintain soil organic matter contents and thereby contribute to enhanced fertiliser use efficiency.

The use of organic amendments in cropping systems is the most viable option for farmers to maintain their field in a productive state. The benefit of organic amendments is not new for many farmers. However, only small fractions of animal manure and crop residues are retained on farmlands in many developing countries due to the low production of manure, the limited availability of labour and the inefficient collection of manure (Tittonell et al., 2005; Kassie et al., 2009; Baudron et al., 2014). In addition to this, high competition of agricultural waste with other uses (e.g. feed and fuel) results in insufficient application of organic amendments in soils, and this competition has become a major concern. For example, utilisation of agricultural waste for feed and fuel has been identified as a major cause for the slow adoption of conservation agriculture in subSaharan Africa and South Asia (Mekonen and Kohlin, 2009; Baudron et al., 2014; Valbuena et al., 2015). Nevertheless, more than $10 \mathrm{t} \mathrm{ha}^{-1}$ of organic amendment are still recommended for resource poor farmers in many developing counties (Negassa et al., 2005; Hou et al., 2011) but such recommendations do not consider competition in the utilisation of agricultural waste.

It is important to identify the current uses of agricultural waste across different farmers groups and livelihood strategies because it explains the causes for minimum application of organic amendments for cropping systems. It is also essential to determine the farm characteristics that impede farmers using agricultural waste for soil amendment. Baudron et al. (2014); Rimhanen and Kahiluoto (2014); Valbuena et al. (2015) found that most of the crop residues are fed to livestock in sub-Saharan Africa and South Asia countries. In contrast, the majority of farmers in Western Kenya, India and Bangladesh retain over $80 \%$ of crop residues on farmland (Baudron et al., 2014; Valbuena et al., 2015). This variation could be due to the difference in degree of agricultural intensification and high competition of agricultural waste with other uses such as feed or 
fuel (Baudron et al., 2014). Another reason could be differences in terms of farm characteristics and livelihood strategies. Therefore, we hypothesised that farmers with different production goals, degree of intensification and socioeconomic status have different agricultural-waste utilisation strategies. For example, subsistence field crop farmers may prefer to utilise agricultural waste for feed or fuel. In contrast, vegetable producers might apply more manure and retain more crop residues on fields than cereal producers because vegetable production demands a high nutrient input and generates a rapid economic return (Abdulkadir et al., 2013). Similarly, land entitlement might encourage farmers to allocate large quantities of agricultural waste to soil amendment. Availability of labour, farm size and distance could also determine farmers' decisions to allocate agricultural waste for soil amendment since investment is required to transport agricultural waste (Tittonell et al., 2010). However, no studies have been conducted to explain variation in utilisation of agricultural waste across different livelihood strategies and production goals.

It is clear that only very small fractions of agricultural waste are allocated to soil amendment in many developing countries (Baudron et al., 2014; Jaleta et al., 2014; Rimhanen and Kahiluoto, 2014). Therefore, other organic resources (e.g. urban waste) should be considered as an alternative option for soil amendment in urban and periurban farming systems in developing countries. Previous studies have suggested the use of urban waste compost to enhance urban agricultural production (Danso et al., 2006; Mary et al., 2010). However, there are very few studies on urban-waste compost demand between different farmers groups and production goals using contingent valuation method (Danso et al., 2006). Contingent valuation method (CVM) is a widely used method to estimate the economic values of environmental services (Danso et al., 2006). Thus, the specific objectives of this study were: (i) to investigate the utilisation of agricultural waste between different urban farmers and link this use with partial nutrient balances, (ii) to identify farm characteristics that influence farmers' decisions to use agricultural waste as a soil amendment, and (iii) to assess the demand for nonagricultural waste (i.e. urban waste) compost.

\section{Materials and Methods}

\section{Study area}

The study was conducted in Addis Ababa, the capital city of Ethiopia. Addis Ababa is located between 2400 and $3100 \mathrm{~m}$ above sea level and has a total land area of $530 \mathrm{~km}^{2}$. The average low and high temperatures are 10 and $25{ }^{\circ} \mathrm{C}$ respectively. Annual precipitation is $1180 \mathrm{~mm}$. It has a unimodal rainfall regime starting in June and lasting until September. The dominant soil type is Vertisol, and the parent material is olivine basalt (Tekalign et al., 1993). Urban farmers who grow crops in the study area are 
approximately 7,000 (Mengistu, 2013). Teff (Eragrostis tef), wheat (Triticum sp. ) and chickpea (Cicer arietinum) are the main crops grown in the area. Cabbage (Brassica oleracea), Ethiopian mustard (Brassica carinata), potato (Solanum tuberosum) and carrot (Daucus carota) are the main vegetables grown. Cattle, donkeys and sheeps are the main livestock types kept by farmers. The poor solid-waste management system is one of the main problems in the city. The current waste generation is about 1,000 tons day ${ }^{-1}$. The average daily waste generation is $32 \mathrm{~kg}$ person $^{-1} \mathrm{yr}^{-1}$ (Guerrero et al., 2013). About $76 \%$ of the urban waste is household waste and over $50 \%$ of the urban waste consists of organic materials that can be recycled into compost (Regassa et al., 2011). From the total waste generated, only $65 \%$ is collected, and the remaining $35 \%$ is dumped on open sites, drainage channels, rivers and streets (Guerrero et al., 2013). Currently, less than $5 \%$ of the urban waste is composted (Mengistu, 2013).

\section{Socioeconomic survey}

Areas that represent the current agricultural systems and heterogeneities of livelihood strategies were selected using secondary sources and governmental and nongovernmental organisations. Discussions were held with key informants who worked in agricultural offices in order to obtain information about the farmers, their locations and other relevant information. A total of 220 households were randomly selected, and individual farmers were interviewed using a standardised semi-structured questionnaire and informal conversation. The sample size was determined according to Israel (1992) who recommended a minimum of 200 samples for population size between 5,000 and 10,000 at $95 \%$ confidence level and $7 \%$ precision level. The questionnaire was pre-tested with 12 respondents and modifications were made on the basis of this pre-test. Field observations and discussions with key informants, and governmental and nongovernmental organisations (NGOs) were used to supplement the household interviews. The qualitative and quantitative variables used in the study are given in Table 2.1. 
Table 2.1. Description of variables used in the study

\begin{tabular}{|c|c|c|}
\hline No & Variables and proxies & Description and unit \\
\hline \multicolumn{3}{|c|}{ Socioeconomic variables } \\
\hline & Education & $\begin{array}{l}\text { Formal education level of the } \mathrm{HH} \text { ( } 0 \text { for illiterate; } 1 \text { for primary school; } \\
2 \text { for secondary school) }\end{array}$ \\
\hline & Sex & $=1$ if the $\mathrm{HH}$ is male; 0 otherwise \\
\hline & Age & Age of the $\mathrm{HH}$ (in years) \\
\hline & Labour & Total active work force \\
\hline & Farming experience & Years of the HH's involvement in urban and peri-urban agriculture \\
\hline & Land size & Total size of the farm (ha) \\
\hline & Farm distance & Distance between home and farm (minutes) \\
\hline & Land tenure & $\begin{array}{l}=1 \text { if the } \mathrm{HH} \text { considered that he/she would be able to use the parcel } \\
\text { for a long time, } 0 \text { otherwise }\end{array}$ \\
\hline & Tropical livestock unit (TLU) & The total number of animals reared by the $\mathrm{HH}$ expressed in $\mathrm{TLU}^{* *}$ \\
\hline & Access to extension services & $=1$ if the $\mathrm{HH}$ has access to extension services, 0 otherwise \\
\hline & Awareness of soil fertility problems & $\begin{array}{l}=1 \text { if the } \mathrm{HH} \text { identifies soil fertility problems on his/her land, } 0 \\
\text { otherwise }\end{array}$ \\
\hline & Non-farm activities & $=1$ if the $\mathrm{HH}$ is involved in non-farm activities, 0 otherwise \\
\hline & Income & Total gross income of the $\mathrm{HH}$ from agriculture in $\$ \mathrm{US}$ \\
\hline \multicolumn{3}{|c|}{ Compost and farmers } \\
\hline & $\begin{array}{l}\text { Farmers' experience of } \\
\text { compost/manure }\end{array}$ & $=1$ if the $\mathrm{HH}$ applied compost/manure, 0 otherwise \\
\hline & $\begin{array}{l}\text { Willingness to participate in urban } \\
\text { waste compost }\end{array}$ & $\begin{array}{l}=1 \text { if the } \mathrm{HH} \text { is willing to contribute money or labour or both, } 0 \\
\text { otherwise }\end{array}$ \\
\hline & Money to contribute & $\begin{array}{l}=\text { amount of money (\$ US) the HH is willing to contribute for } 100 \mathrm{~kg} \text { of } \\
\text { urban waste compost }\end{array}$ \\
\hline & Labour to contribute & $\begin{array}{l}=\text { amount of labour (days) the } \mathrm{HH} \text { is willing to contribute for } 100 \mathrm{~kg} \text { of } \\
\text { urban waste compost per year }\end{array}$ \\
\hline \multicolumn{3}{|c|}{ Production systems } \\
\hline & Field crop production & $=1$ if the $\mathrm{HH}$ is involved in field crop production, 0 otherwise \\
\hline & Garden vegetable production & $=1$ if the $\mathrm{HH}$ is involved in vegetable production, 0 otherwise \\
\hline & Livestock production & $=1$ if the $\mathrm{HH}$ is involved in livestock production, 0 otherwise \\
\hline & Ornamental plants & $=1$ if the $\mathrm{HH}$ is involved in ornamental plant production, 0 otherwise \\
\hline & INC_ cereal & $\begin{array}{l}\text { = Contribution of field crop to } \mathrm{HH} \text { income (highest, moderate, low, } \\
\text { none) }\end{array}$ \\
\hline & INC_ vegetable & $\begin{array}{l}\text { = Contribution of vegetable to } \mathrm{HH} \text { income (highest, moderate, low, } \\
\text { none) }\end{array}$ \\
\hline & INC_ animal & $\begin{array}{l}\text { = Contribution of animals to } \mathrm{HH} \text { income (highest, moderate, low, } \\
\text { none) }\end{array}$ \\
\hline & INC_ ornamental & $\begin{array}{l}\text { = Contribution of ornamental plants to HH income (highest, } \\
\text { moderate, low, } \\
\text { none) }\end{array}$ \\
\hline
\end{tabular}

*The total active workforce was calculated as follows: 1.0 for males aged between 16 and 55 years; 0.75 for females between 15 and 55 years; 0.75 for males above 55 years and 0.5 for females above 55 years. Those below 15 years of age were not considered in workforce calculations (Dossa et al., 2011); ${ }^{* *}$ TLU = tropical livestock unit, hypothetical animal of $250 \mathrm{~kg}$ live weight; TLU conversion factors used: camel $=1$, cattle $=0.80$, sheep and goats $=0.10$, donkey $=0.5 ;$ pigs $=0.20$, poultry and rabbit=0.01. $\mathrm{HH}=$ household head; $\$ \mathrm{US}=$ United States dollar

\section{Sampling and laboratory analyses}

Samples were collected from soil, plant, irrigation water, manure and compost to quantify partial balances of nitrogen $(\mathrm{N})$, phosphorus $(\mathrm{P})$, and potassium $(\mathrm{K})$ across different farms. Due to budget constraints, only three farms were selected from each farmers group after we identified different farmer categories. The farms which represent 
each category were selected through detailed observation, discussion with farmers and development agents. Three sub-plots $\left(1 \mathrm{~m}^{2}\right)$ were prepared in each farm (Abdulkadir et al., 2012). Soil and plant samples were collected from these sub-plots. Composite soil samples were taken from the $0-25 \mathrm{~cm}$ layer and air-dried for laboratory analysis. The hydrometer method was used to determine soil texture, and $\mathrm{pH}-\mathrm{H}_{2} \mathrm{O}$ was measured in a 1:2.5 soil-to-water suspension. Soil carbon was analysed using the Walkley-Black method, total $\mathrm{N}$ using Kjeldahl digestion, available $\mathrm{P}$ using Olsen extraction and soil $\mathrm{K}$ using aqua regia digestion (Van Reewijk, 1992). Plant, manure and compost samples were also collected and weighed immediately after sampling to determine fresh weight. Plant samples were oven-dried at $60^{\circ} \mathrm{C}$ for three days, then ground and sieved for $\mathrm{N}, \mathrm{P}$ and K analyses (Van Reewijk, 1992). Nitrogen in plant tissue was analysed using Kjeldahl digestion, while $\mathrm{P}$ and $\mathrm{K}$ were measured using vanadomolybdophosphoric acid extraction and atomic absorption respectively. Nitrogen, phosphorus and potassium in water, compost and manure were analysed as described earlier. Nitrogen, $\mathrm{P}$ and $\mathrm{K}$ concentrations in plant, manure and compost samples were multiplied by their dry mass to estimate element fluxes (Eq. (1)).

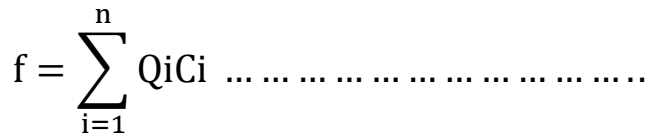

where $f$ is the input or output flow of $\mathrm{N}, \mathrm{P}$ or $\mathrm{K}$ for one year; $\mathrm{n}$ is number of events in a year (growing season; fertilisation (manure or compost); irrigation); $\mathrm{Q}$ is quantity of dry material; $\mathrm{C}$ is concentration of $\mathrm{N}, \mathrm{P}$ or $\mathrm{K}$.

The element balance equation was then calculated as:

$$
B_{e}=I_{e}-O_{e}
$$

where $\mathrm{B}$ is the nutrient balance; e is the element $(\mathrm{N}, \mathrm{P}$ or $\mathrm{K})$; $\mathrm{Ie}$ is input of an element (fertiliser, compost, manure, irrigation) and $\mathrm{O}_{\mathrm{e}}$ is output of an element (harvested crop yield and crop residue).

\section{Data analyses}

Categorical principal component analysis (CATPCA) and two-step clustering were used to classify 220 farmers into different groups (Dossa et al., 2011). Since nominal and metric variables were included in the study, CATPCA was used instead of principal component analysis. CATPCA was performed using IBM SPSS Statistics 22.0 to identify relationships between variables and to reduce a large number of variables into a small number of orthogonal components. According to Abdulkadir et al., (2012), a component (a CATPCA axis) is reliable if it contains at least four variables with a loading score $>0.6$. Based on this criterion, two components were found. The loading score of each variable is presented in Table 2.2. The extracted component scores and variables with a score value $>0.6$ in one of the two components were then used for two-step clustering (Dossa 
et al., 2011). Before running the cluster analysis, a visual binning procedure was performed to convert continuous variables into nominal variables and reduce the higher weight of categorical variables at the expense of continuous variables (Dossa et al., 2011). A silhouette measure of cluster cohesion and separation - which was used for measuring the quality of the clustering solution - showed a good clustering quality because the value was between 0.6 and 0.7. Analysis of variance (ANOVA) for continuous variables and chi-square for categorical variables were used to test for significant differences between the clusters.

Table 2.2. Component loadings of socioeconomic variables used for categorical component analysis (CATPCA)

\begin{tabular}{lcc}
\hline Variable & \multicolumn{2}{c}{ Dimension } \\
\cline { 2 - 3 } & 1 & 2 \\
\hline Farming experience & 0.635 & 0.081 \\
Age of HH & 0.259 & 0.192 \\
Sex of HH & 0.202 & -0.339 \\
Education status of HH & -0.437 & -0.197 \\
Active labour force & -0.445 & 0.123 \\
Area of the farmland & 0.722 & -0.116 \\
Farm distance & 0.782 & -0.103 \\
TLU & 0.685 & 0.136 \\
Awareness of soil fertility & -0.153 & -0.146 \\
HH involved in field crop production & 0.900 & -0.100 \\
HH involved in vegetable production & -0.532 & 0.785 \\
HH involved in animal rearing & 0.823 & 0.210 \\
HH involved in ornamental plant production & -0.424 & -0.821 \\
Contribution of field crop to HH income & 0.916 & -0.148 \\
Contribution of vegetable to HH income & -0.583 & 0.781 \\
Contribution of animals to HH income & 0.738 & 0.190 \\
Contribution of ornamental plants to HH income & -0.424 & -0.821 \\
Contribution of non-farm activities to HH income & -0.205 & -0.362 \\
\hline Cronbach's alpha & 0.89 & 0.71 \\
Total eigenvalue & 5.67 & 2.88 \\
\% variance & 43.58 & 22.16 \\
\hline
\end{tabular}

$\mathrm{HH}=$ household head; TLU $=$ tropical livestock unit

The contingency valuation method (CVM) using dichotomous choice was implemented to estimate the demand for urban waste compost via a willingness to contribute money or labour (Danso et al., 2006). In our study, labour was also used to estimate compost demand because resource-poor farmers might prefer to contribute labour rather than 
money since cheap labour is more easily available than cash in many developing countries. Therefore, farmers were also asked to state the amount of labour they were willing to contribute in addition to cash. The labour was then converted into wages to estimate the demand. The questionnaires were designed to avoid strategic and starting point biases of the CVM method. A binary logit model was then used to determine socioeconomic variables that influence farmers' demand for urban-waste compost. The dependent variable was considered to be one when respondents were willing to contribute money, labour or both, and zero otherwise. The logit model used for this study is that described by Gujarati (1995).

\section{Results}

\section{Categorical principal component and two-step cluster analyses}

The results of CATPCA are presented in Table 2.2 and Figure 2.1. Eighteen variables were used, and two reliable component solutions were obtained from the analysis. The first component accounted for $44 \%$ of the variance, while the second component accounted for $22 \%$. The third component was not considered reliable because it accounted for only $12 \%$ of the variance, and it had one variable (Age) with a score value $>0.6$. Farm experience, land size, farm distance, number of tropical livestock units (TLU), income from cereals and income from animals were the variables that showed the strongest relationship with the first component. Income from garden and income from ornamental plants showed the strongest correlation with the second component. Cronbach's alpha values, which measure how closely related the variables are as a group, were 0.89 and 0.71 for components one and two respectively. These Cronbach's alpha values suggest that the variables have a high internal consistency since these values are larger than 0.70. Vectors pointing in the same direction in Figure 2.1 were more correlated, and the length of the vectors indicated the most influential variables. Therefore, variables that were related to farming strategies, income source and resource endowment were the dominant variables for CATPCA analysis. The extracted component scores and variables with a score value $>0.6$ in one of the two components were used for two-step cluster analysis. Accordingly, the two-step cluster analysis identified four groups of farmers that were different in terms of livelihood strategies, technology choice, utilisation of agricultural waste and soil fertility management. The socioeconomic characteristics of each group are presented in Table 2.3 and presented below. 


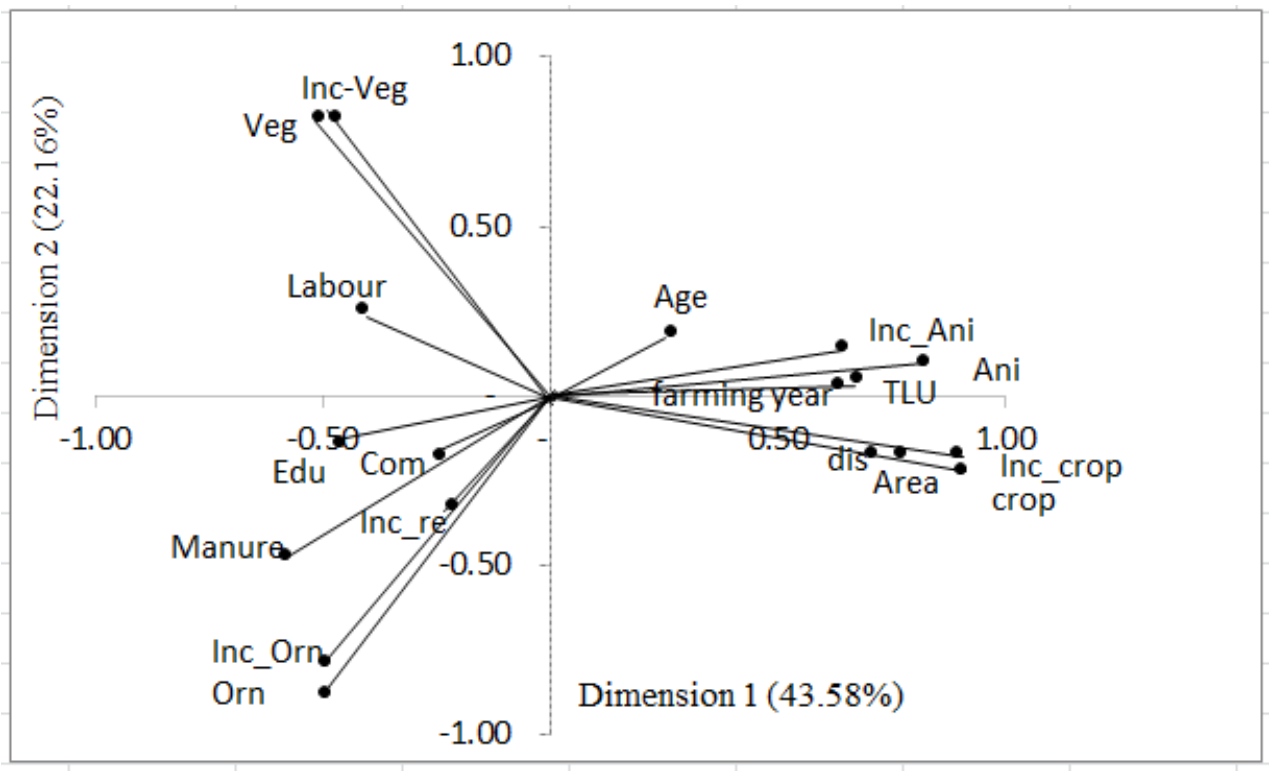

Figure 2.1. Loadings obtained from categorical principal component analysis describing the relationship between socioeconomic variables. Veg = vegetable growers; Inc_ Veg = income from

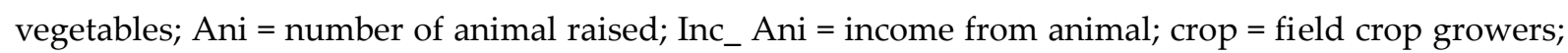
Inc _ crop = income from field crops; orn= ornamental plant growers; Inc_ ornamental= income from ornamental plants; Inc_ re= income from non-farm activities; TLU= tropical livestock unit; Edu = educational status; comp = compost users; dis = farm distance; area $=$ land size .

\section{Classification of urban and peri-urban farmer groups}

Cluster I (Subsistence field crop farmers): Farmers included in this group were located in peri-urban areas. These farmers used to be rural farmers, but their land has been encroached upon by expansion of the city. The agricultural activities were characterised by subsistence field crop production. Wheat (Triticum sp.) and teff (Eragrostis tef) were the dominant field crops. Legumes including chickpea (Cicer arietinum), grass pea (Lathyrus sativus) and lentil (Lens culinaris) were also grown in crop rotation as food crops. In addition to crop production, these farmers raised animals. The average herd size of these farmers in TLU was 7.64, which was significantly $(P<0.01)$ higher than for the other groups of farmers (Table 2.3). The average gross annual income of these farmers was the lowest because field crop production contributed most of the household income. Many field crop farmers had large farms (2.64 ha) but $84 \%$ of these farmers had insecure landownership due to urban encroachment. Many of them had lost their farmlands due to urbanisation. As a result, these farmers were forced to grow crops by renting land from peri-urban and rural farmers. Farmers in this group used family labour for agricultural activities. Field crop farmers had less access to institutional support including credit and extension services. A large number of these farmers (47\%) were illiterate, and they had been engaged in agricultural activities for more than 25 years. 
Cluster II (Mixed farmers): These farmers were the intermediate category between clusters I and II. These farmers were on the way from being field crop farmers to becoming vegetable farmers due to urban encroachment and land shortage. Farmers in this group practised a mixed field crop -vegetable-livestock production system. The average heard size in TLU was 4.29 (Table 2.3). Most of the household income was generated from field crop production, with a moderate to low contribution from vegetable and livestock activities. Many farmers in this group had less access to institutional support compared to vegetable and ornamental-plant producers. Farmers in this group had large farms (1.52 ha), but ownership was insecure because field crops were grown in peri-urban areas where urban encroachment is a problem.

Cluster III (Vegetable producers): These farmers were characterised as small-scale commercial vegetable producers. In addition to vegetable production, $38 \%$ of farmers in this group raised animals. Even though vegetables contributed most to the household income, $32 \%$ of these farmers also engaged in non-farm activities such as private businesses and temporary urban occupations. Female participation in vegetable production was higher than in the other groups. About $20 \%$ of the vegetable producers were female. The majority of vegetable producers (60\%) had access to extension services, and they were organised into cooperatives and small enterprises. The land size of these farmers was very small (0.34 ha), but they had relatively secure land ownership compared to field crop farmers because vegetable production was mainly carried out near the homestead or main rivers. Flooding was the principal problem for many vegetable farmers. Vegetable production is labour intensive, therefore farmers in this group hired labour, especially during weeding and harvesting. The labourers were mostly urban dwellers, however a few field crop farmers were also working for vegetable producers. As a result, the average labour force (7.56) involved in this farming system was significantly $(\mathrm{P}<0.01)$ higher than for the other groups.

Cluster IV (Ornamental-plant growers): Farmers with commercialised ornamental-plant production constituted this group. Most of these farmers were urban dwellers who created new jobs. These farmers were literate (93\%) and engaged in nonfarm activities (53\%). Non-farm activities carried out by ornamental-plant growers included private businesses and permanent or temporary jobs in governmental and nongovernmental organisations. The contribution of non-farm activities to household income was moderate to high. This farming system is new in many developing countries. Similarly, the average farm experience of these farmers was 12 years (Table 2.3). Ornamental plants were grown near the homestead or main roads. As with vegetable producers, ornamental-plant growers had good access to institutional support including credit services. Many ornamental-plant growers also hired labour from urban areas. 
Table 2.3. Socioeconomic characteristics of urban and peri-urban farmers in the study area

\begin{tabular}{|c|c|c|c|c|c|}
\hline Socioeconomic characteristics & $\begin{array}{l}\text { Field crop } \\
\text { producers }\end{array}$ & Mixed farmers & $\begin{array}{l}\text { Vegetable } \\
\text { producers }\end{array}$ & $\begin{array}{l}\text { Ornamental } \\
\text { plant growers }\end{array}$ & P-value \\
\hline No (\%) of households & $76(34.6 \%)$ & $22(10.0 \%)$ & $81(36.8 \%)$ & $41(18.6 \%)$ & \\
\hline \multicolumn{6}{|l|}{ Human capital } \\
\hline Farming experience (year) & $26.2 \mathrm{a}$ & $18.9 \mathrm{~b}$ & $13.9 b$ & $11.7 \mathrm{~b}$ & ** \\
\hline Age of the HH (year) & 43.9 & 46.5 & 42.8 & 43.3 & NS \\
\hline Educational status & 0.5 & 0.7 & 0.8 & 0.9 & $* * *$ \\
\hline Active labour force & $4.0 \mathrm{~b}$ & $5.2 \mathrm{~b}$ & $7.6 \mathrm{a}$ & $5.5 b$ & $* *$ \\
\hline \multicolumn{6}{|l|}{ Natural capital } \\
\hline Total land size (ha) & $2.6 a$ & $1.5 \mathrm{a}$ & $0.3 \mathrm{~b}$ & $0.2 \mathrm{~b}$ & $* *$ \\
\hline Tropical livestock unit & $7.6 a$ & $4.3 \mathrm{~b}$ & $3.8 \mathrm{~b}$ & $1.1 \mathrm{c}$ & $* *$ \\
\hline Number of cattle (per $\mathrm{HH}$ ) & $7.5 \mathrm{a}$ & $4.9 \mathrm{ab}$ & $3.4 b$ & $1.0 \mathrm{c}$ & $* *$ \\
\hline $\begin{array}{l}\text { Number of small animals (per } \\
\mathrm{HH} \text { ) }\end{array}$ & $4.2 \mathrm{a}$ & $1.3 \mathrm{~b}$ & $2.0 \mathrm{~b}$ & $0.1 \mathrm{c}$ & $* *$ \\
\hline Number of equines (per $\mathrm{HH}$ ) & $1.8 \mathrm{a}$ & $0.6 b c$ & $0.7 \mathrm{~b}$ & $0.0 \mathrm{c}$ & ** \\
\hline Land tenure status (\%) & 0.2 & 0.4 & 0.8 & 0.7 & $* * *$ \\
\hline \multicolumn{6}{|l|}{ Social capital } \\
\hline Access to extension services (\%) & 0.2 & 0.4 & 0.6 & 0.7 & $* * *$ \\
\hline \multicolumn{6}{|l|}{ Financial capitals } \\
\hline Non-farm activities (\%) & 0.3 & 0.3 & 0.3 & 0.5 & $* * *$ \\
\hline $\begin{array}{l}\text { Annual gross income from } \\
\text { agriculture (in \$ US) }\end{array}$ & $475.0 \mathrm{c}$ & $903.0 \mathrm{~b}$ & $850.0 \mathrm{~b}$ & 1070.0a & $* *$ \\
\hline
\end{tabular}

\section{Partial nutrient balances and soil fertility management practices}

Partial balances of N, P and K under different urban and peri-urban farming systems are presented in Figure 2.2. Partial nutrient balances varied significantly $(\mathrm{P}<0.01)$ between different groups of farmers. The $\mathrm{N}$ balance was negative in mixed farming and field crop production, but positive $\left(20 \mathrm{~kg} \mathrm{ha}^{-1} \mathrm{yr}^{-1}\right)$ in vegetable farms. The partial balance for $\mathrm{P}$ was positive in all farms ranging from $18 \mathrm{~kg} \mathrm{ha}^{-1} \mathrm{yr}^{-1}$ on croplands to $22 \mathrm{~kg} \mathrm{ha}^{-1} \mathrm{yr}^{-1}$ on vegetable farms. In contrast, the $\mathrm{K}$ balance was negative on all farms. The most negative $\mathrm{K}$ balance (minus $43 \mathrm{~kg} \mathrm{ha}^{-1} \mathrm{yr}^{-1}$ ) was observed in vegetable farms. The observed variation in nutrient balances resulted from differences in soil fertility management between the groups (Table 2.4). 

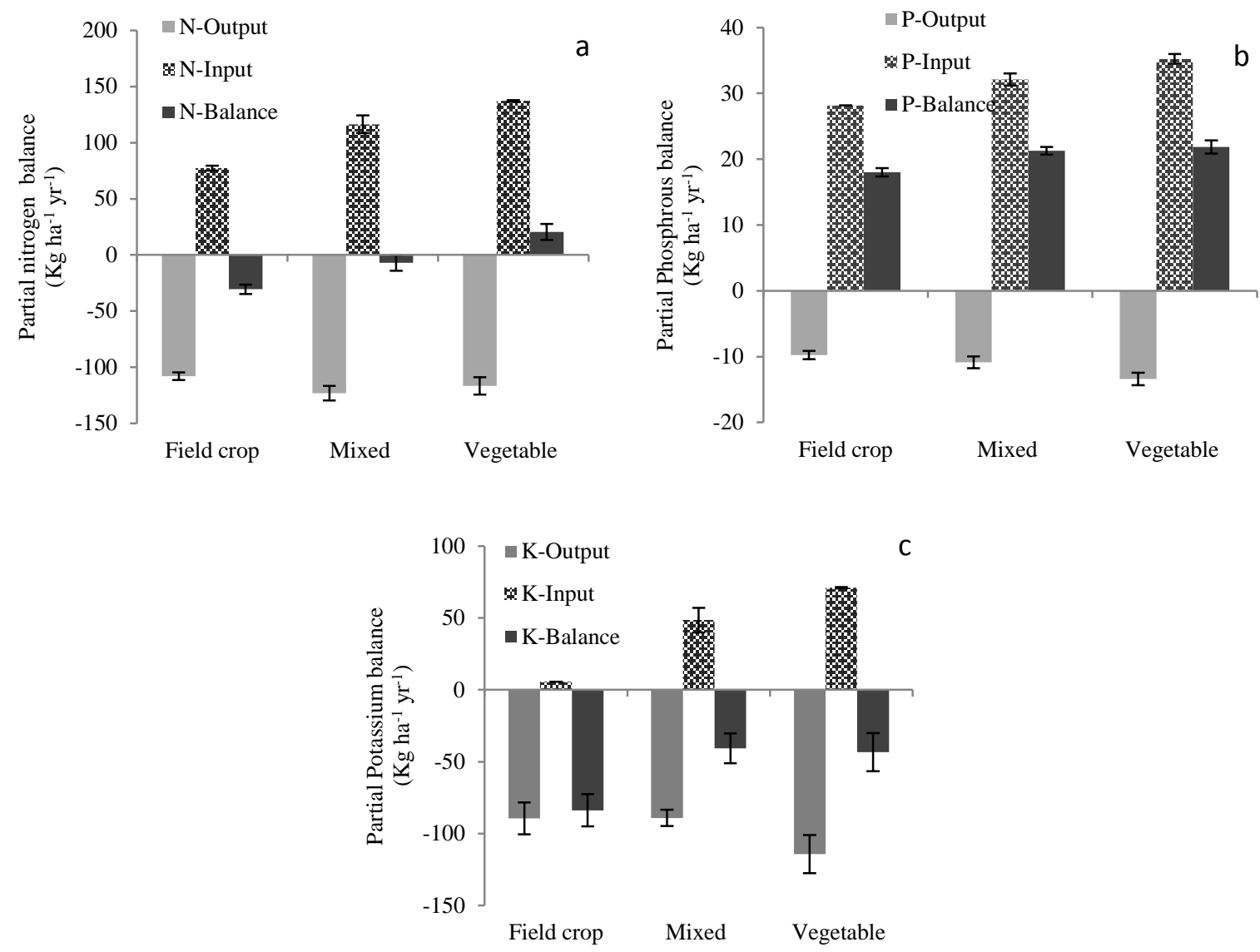

Figure 2.2. Partial nutrient balance of different urban and peri-urban production systems (a) nitrogen balance, (b) phosphorus balance, (c) potassium balance; Ornamental-plant growers are not included because there were so many plants on each farm, and each farm has different plants, which makes the calculation very difficult and expensive.

Table 2.4. Soil fertility management strategies of different urban and peri-urban farmers

\begin{tabular}{lccccc}
\hline \multirow{2}{*}{$\begin{array}{c}\text { Soil fertility management strategy } \\
\text { based on: }\end{array}$} & \multicolumn{4}{c}{ Percentage of farmers that apply the strategy } \\
\cline { 2 - 6 } & $\begin{array}{c}\text { Field crop } \\
\text { producers }\end{array}$ & Mixed farmers & $\begin{array}{c}\text { Vegetable } \\
\text { producers }\end{array}$ & $\begin{array}{c}\text { Ornamental } \\
\text { plant growers }\end{array}$ & $X^{2}$ \\
\hline Compost & 9 & 18 & 22 & 39 & $* *$ \\
Manure & 9 & 27 & 31 & 96 & $* *$ \\
Inorganic fertilisers & 97 & 100 & 73 & 39 & $* *$ \\
Legumes rotation & 67 & 27 & - & - & $* *$ \\
\hline
\end{tabular}

** Significant at $\mathrm{P}<0.01$

The physical and chemical properties of soils presented in Table 2.5 were also in agreement with the nutrient balance. In general, inorganic fertilisers (urea and diammonium phosphate) were the primary source of nutrient inputs, but many farmers applied inorganic fertilisers below the recommended rate due to their high price. About $78 \%$ of the respondents were aware of the benefits of organic amendments, and $63 \%$ of respondents had access to animal manure. However, the use of manure for soil amendment was very limited (Table 2.4). Retention of crop residues on soil was also 
limited in the study area. The majority of farmers retained less than $10 \%$ of crop residues on their fields. Ornamental-plant and vegetable growers applied higher amounts of organic amendments compared to the other two clusters. Most ornamental-plant growers applied organic amendments at the rate of $6 \mathrm{t} \mathrm{ha}^{-1} \mathrm{yr}^{-1}$ while vegetable producers applied organic amendments less than $3 \mathrm{t} \mathrm{ha}^{-1} \mathrm{yr}^{-1}$. About $96 \%$ of ornamental plant growers applied manure and 39\% applied compost from plant residues. In contrast, 31\% of vegetable growers, $27 \%$ of mixed farmers and $9 \%$ of field crop producers applied manure on their farmlands. Similarly, $22 \%$ of vegetable growers, $18 \%$ of mixed farmers and $9 \%$ of field crop producers used compost as soil amendment (Table 2.4).

Table 2.5. Physical and chemical properties of soils $(0-25 \mathrm{~cm})$

\begin{tabular}{|c|c|c|c|c|}
\hline Soil properties & $\begin{array}{l}\text { Field crop farmers } \\
(n=3)\end{array}$ & $\begin{array}{l}\text { Mixed farmers } \\
(n=3)\end{array}$ & $\begin{array}{l}\text { Vegetable } \\
\text { farmers } \\
(n=3)\end{array}$ & P-Value \\
\hline Clay (\%) & 66.2 & 61.0 & 43.9 & NS \\
\hline Silt (\%) & 22.6 & 26.0 & 34.7 & NS \\
\hline Sand (\%) & $11.2 b$ & $13.0 \mathrm{ab}$ & $21.4 \mathrm{a}$ & * \\
\hline $\mathrm{pH}-\mathrm{H}_{2} \mathrm{O}$ & 7.3 & 7.4 & 7.6 & NS \\
\hline Organic carbon $(\%)$ & $1.2 b$ & $1.4 \mathrm{~b}$ & $2.2 \mathrm{a}$ & $* *$ \\
\hline Total nitrogen (\%) & $0.1 b$ & $0.1 b$ & $0.2 \mathrm{a}$ & $* *$ \\
\hline Olsen-P (mg kg-1) & $17.9 \mathrm{c}$ & $43.4 b$ & $89.1 \mathrm{a}$ & ** \\
\hline CEC $(\mathrm{cmol}(+) / \mathrm{kg}$ soil $)$ & 58.3 & 61.3 & 45.2 & NS \\
\hline Exch Ca $(\mathrm{cmol}(+) / \mathrm{kg}$ soil $)$ & 44.2 & 45.9 & 31.3 & NS \\
\hline Exch $\mathrm{Mg}(\mathrm{cmol}(+) / \mathrm{kg}$ soil $)$ & 10.3 & 8.1 & 9.5 & NS \\
\hline Exch K (cmol (+)/kg soil) & $1.8 \mathrm{~b}$ & $1.4 \mathrm{~b}$ & $2.1 \mathrm{a}$ & * \\
\hline Total P $\left(\mathrm{g} \mathrm{kg}^{-1}\right)$ & $0.6 \mathrm{~b}$ & $0.8 \mathrm{ab}$ & $1.0 \mathrm{a}$ & $* *$ \\
\hline Total $\mathrm{K}\left(\mathrm{g} \mathrm{kg}^{-1}\right)$ & $3.0 \mathrm{~b}$ & $4.12 \mathrm{a}$ & $4.6 \mathrm{a}$ & ** \\
\hline
\end{tabular}

* Ornamental plant growers are not included because these farmers used pot soils whose properties varied from farm to farm; $\mathrm{CEC}=$ cation exchange capacity; $\mathrm{Exch}=$ exchangeable ${ }^{*},{ }^{* *}$ denote significant difference at $\mathrm{P}<0.05$ and $\mathrm{P}<0.01$ respectively

\section{Current uses of agricultural waste}

The current uses of agricultural waste across different farmers groups are presented in Figure 2.3. Three major uses for animal manure and crop residues were identified. Agricultural-waste utilisation varied significantly $(\mathrm{P}<0.001)$ between the different farmer groups. All respondents used animal manure, mainly for household fuel consumption. Field crop farmers allocated over $80 \%$ of manure to fuel consumption and only $5-10 \%$ to soil amendment. In contrast, ornamental-plant producers allocated $34 \%$ of manure to fuel and 56\% to soil. Crop residues were used primarily for feed. Field crop producers and mixed farmers allocated over $83 \%$ and $76 \%$ of crop residues to animal feed respectively. In contrast, vegetable producers retained $62 \%$ of crop residues on their field. Ornamental-plant growers produced negligible quantities of crop residues; therefore, their residue allocation has not been studied. Manure and crop residues also served as income sources for many urban farmers. Many respondents sold manure and 
crop residues (teff (Eragrostis tef)) and earned more than $\$ 50 \mathrm{yr}^{-1}$. This is equivalent to 5$10 \%$ of their annual income. A very small fraction of crop residues was allocated to fuel. The econometric analysis (Table 2.6) indicated the socioeconomic variables that correlated with allocation of agricultural waste to soil amendment. The results show that farmers who have access to extension services allocated manure and crop residues mainly to soil amendment. Access to physical assets (i.e. landownership and land size) also influenced farmers' decisions to use agricultural waste for soil amendment. Farmers with insecure landownership allocated agricultural waste mainly to household fuel consumption. The relationship between the educational status of the household head and utilisation of agricultural waste is illustrated in Figure 2.4. Farmers with a better educational status allocated a larger fraction of their agricultural waste to soil amendment. Farmers with a higher tropical livestock unit (TLU) also used crop residues, especially for animal feed; however, the relationship between the number of cattle and allocation of animal manure for soil amendment was not significant.

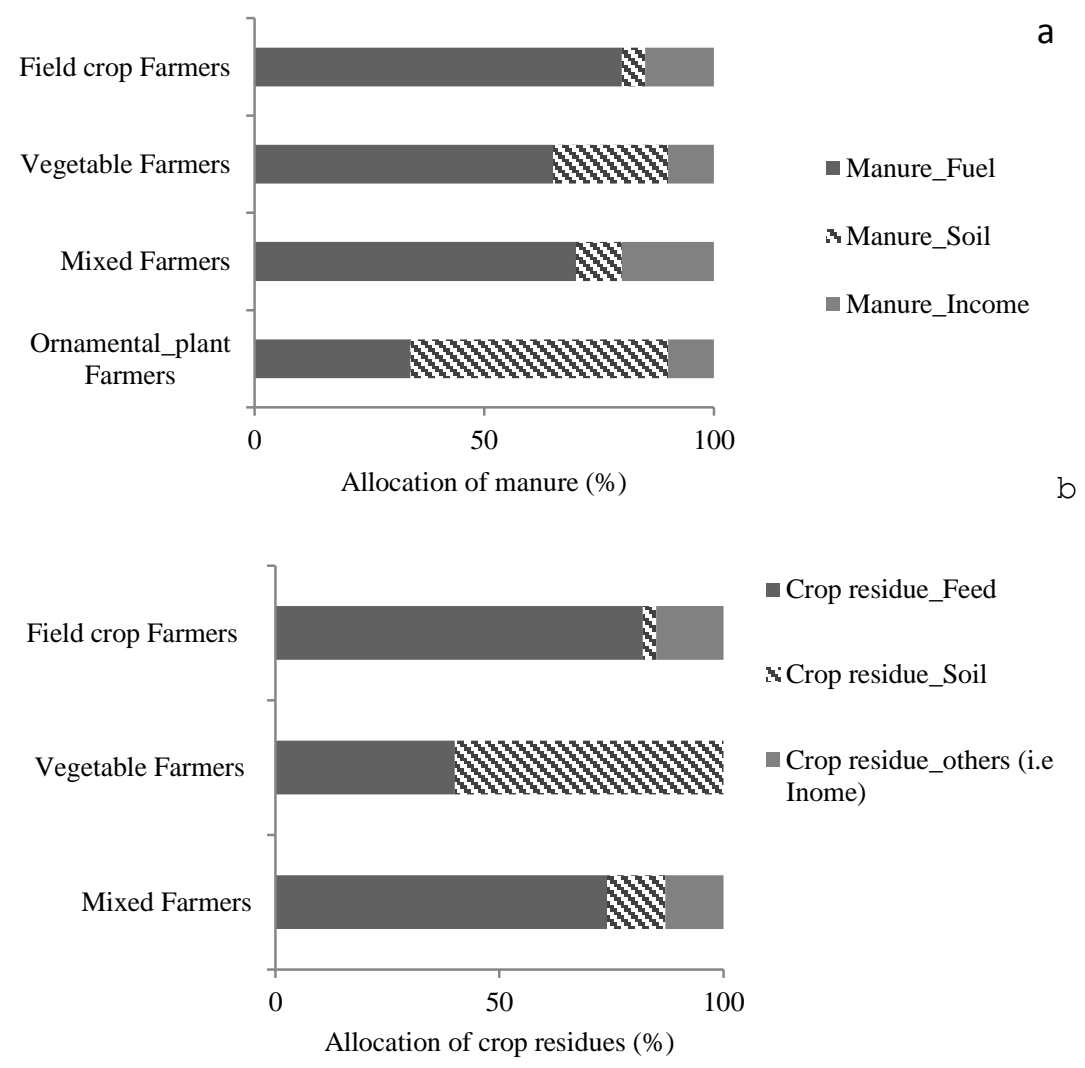

Figure 2.3. Current use of (a) manure and (b) crop residues across different urban and peri-urban farmer groups 


\section{Chapter 2}
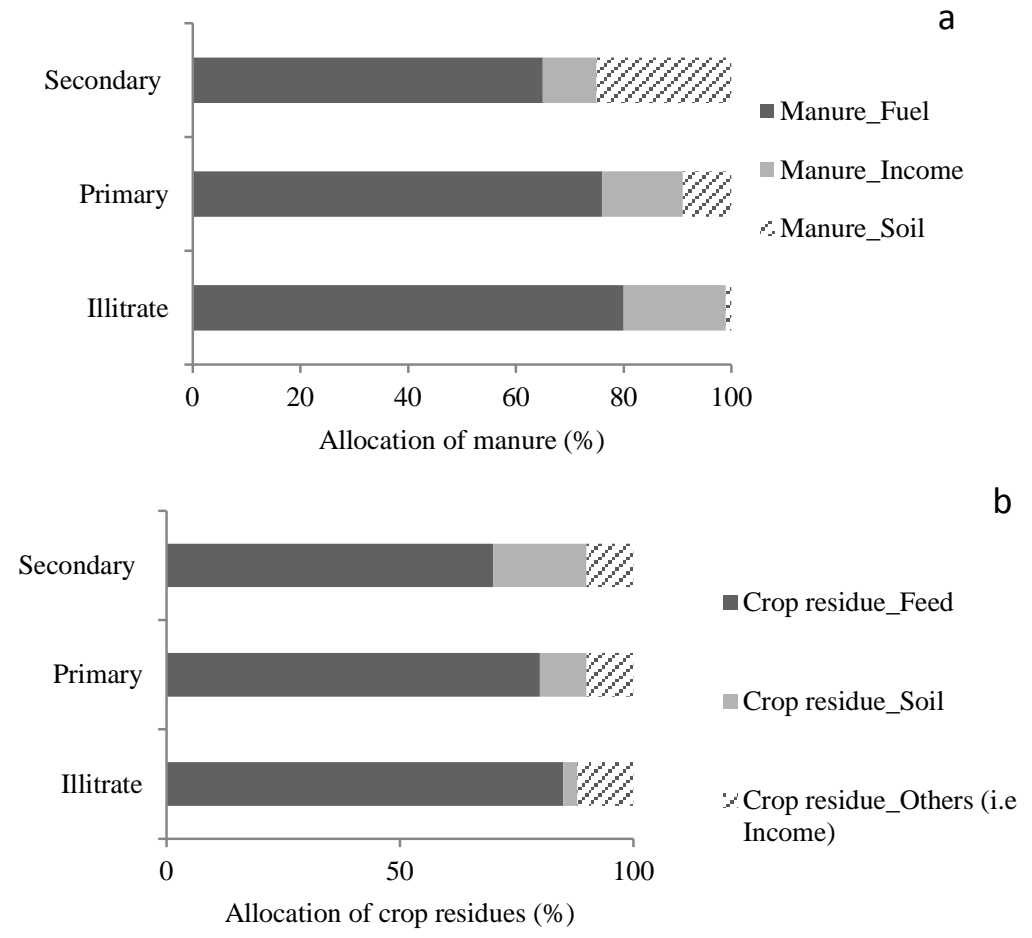

Figure 2.4. Current use of (a) manure and (b) crop residue across different educational status

Table 2.6. Parameter estimates of socioeconomic variables that influence farmers' decisions to use agricultural waste for soil amendment

\begin{tabular}{lcccc}
\hline Variables & \multicolumn{2}{c}{ Manure for soil amendment } & \multicolumn{2}{c}{ Crop residue for soil amendment } \\
\cline { 2 - 5 } & Coefficient & Wald statistic & Coefficient & Wald statistic \\
\hline Age (year) & -0.031 & 1.758 & -0.014 & 0.533 \\
Gender & 0.734 & 1.062 & -0.434 & 0.751 \\
Educational status of HH & $0.343^{*}$ & 2.468 & 0.153 & 0.616 \\
Labour & 0.103 & 0.859 & 0.016 & 0.088 \\
Total land size (ha) & $-0.598^{* * *}$ & 6.924 & $-0.474^{* *}$ & 4.161 \\
Farm distance (minutes) & $-0.12^{*}$ & 1.193 & 0.024 & 2.228 \\
Tropical livestock unit & 0.040 & 0.899 & -0.015 & 0.206 \\
Awareness of soil fertility problem & $1.292^{* *}$ & 3.400 & 0.222 & 0.195 \\
(\%) & $0.886^{*}$ & 2.011 & $0.815^{* *}$ & 2.718 \\
Land tenure (\%) & $1.009^{*}$ & 2.380 & 0.459 & 0.587 \\
Access to extension service (\%) & -4.553 & $9.262^{* * *}$ & -0.154 & 0.018 \\
\hline Constant & 110.48 & & 160.85 & $50.54^{* * *}$ \\
-2 log-likelihood & $55.49^{* * *}$ & & 76.20 & \\
Chi-square values & 80.80 & & \\
Per cent correctly predicted & & & \\
\hline$* * * * *$ & & & \\
\hline
\end{tabular}

$*$ ****** denote significance at $\mathrm{P}<0.01, \mathrm{P}<0.05$ and $\mathrm{P}<0.01$ respectively; $\mathrm{HH}=$ household head 


\section{Demand for urban-waste compost}

Since there is high competition of agricultural waste with other uses such as feed and fuel, other organic resources (e.g. urban-waste compost) should be considered as an alternative option for soil amendment in urban and peri-urban farming systems. More than $58 \%$ of the respondents expressed willingness to contribute money and/or labour for urban waste compost; however, the bid varied significantly $(P<0.01)$ between different groups (Table 2.7). Ornamental-plant growers bid the highest price for $100 \mathrm{~kg}$ compost (US\$ 1.76) whereas field crop farmers bid the lowest price (US\$ 0.60). The highest contribution for labour (28 days $\mathrm{yr}^{-1}$ ) was also offered by ornamental-plant growers. Many field crop producers preferred to contribute labour rather than money. About $20 \%$ of field crop farmers were interested in contributing labour, but just $13 \%$ were willing to pay money for urban-waste compost. Farmers who used manure or compost for their cropping systems showed a higher demand for urban-waste compost than non-users. About $89 \%$ of manure/compost users were willing to contribute money and/or labour, but only $45 \%$ of non-users were interested in urban waste compost. The econometrics analysis also identified socioeconomic variables that explained the variation in urban compost demand (Table 2.8). Education, landownership, experience with compost and access to extension services were the variables that determined the demand for urban-waste compost.

Table 2.7. Willingness of urban and peri-urban farmers to participate in urban-waste composting

\begin{tabular}{|c|c|c|c|c|c|c|}
\hline $\begin{array}{l}\text { Urban and peri-urban } \\
\text { farmers group }\end{array}$ & WTP-Labour & WTP-Cash & $\begin{array}{l}\text { WTP-Cash } \\
\text { and labour }\end{array}$ & $\begin{array}{l}\text { WTP1_ }^{1-} \\
\text { Total }\end{array}$ & $\mathrm{WTP}^{2}(\mathrm{USD} \$)$ & $\begin{array}{c}\text { WTP3 } \\
\left(\text { days } \mathrm{yr}^{-1}\right)\end{array}$ \\
\hline Field crop producers & 20 & 13 & 9 & 24 & $0.55(1.96) \mathrm{c}$ & $8.58(1.42) \mathrm{c}$ \\
\hline Vegetable producers & 59 & 81 & 59 & 81 & $1.45(2.34) \mathrm{a}$ & $16.36(3.52) b$ \\
\hline Mixed farmers & 72 & 63 & 59 & 77 & $0.92(3.76) b$ & $14.44(1.84) \mathrm{b}$ \\
\hline \multicolumn{7}{|l|}{ Ornamental plant growers } \\
\hline & 81 & 100 & 81 & 93 & $1.84(2.76) a$ & $28.00(3.8) a$ \\
\hline P-value & $* *$ & $* * *$ & $* * *$ & $* * *$ & $* *$ & $* *$ \\
\hline
\end{tabular}

Chi-square and ANOVA were used to compare categorical and continuous variables respectively; 1: percentage of farmers who were willing to contribute either cash or labour or both for urban waste compost; 2: average bid offered in terms of cash for $100 \mathrm{~kg}$ urban waste compost; 3: average bid offered in terms of labour (days year-1); values in parentheses indicate standard error of the mean; WTP = willingness of farmers to participate in urban waste composting; ${ }^{* *}$ and ${ }^{* * *}$ denote significance at $\mathrm{P}<0.01$ and $\mathrm{P}<0.001$ respectively 
Table 2.8. Parameter estimates for variables that determine farmers' willingness to participate in urban-waste composting

\begin{tabular}{|c|c|c|}
\hline Variables & Coefficient & Wald statistics \\
\hline Age (year) & 0.026 & 1.140 \\
\hline Gender & 0.746 & 1.011 \\
\hline Educational status of $\mathrm{HH}$ & $0.936^{*}$ & 2.981 \\
\hline Labour & 0.042 & 0.261 \\
\hline Total land size (ha) & -0.026 & 0.026 \\
\hline Farm distance (minutes) & -0.003 & 0.068 \\
\hline Total tropical livestock unit & -0.058 & 2.538 \\
\hline Farmer's awareness of soil fertility problem (\%) & 0.027 & 0.002 \\
\hline Farmer's experience of compost (\%) & $2.430^{* *}$ & 13.198 \\
\hline Land tenure (\%) & $1.845^{* *}$ & 12.967 \\
\hline Access to extension services (\%) & $1.656^{* *}$ & 8.541 \\
\hline Income (\$ US) & 0.000 & 0.414 \\
\hline$-^{2} \log$-likelihood & 141.05 & \\
\hline Chi-square values & $132.27^{* *}$ & \\
\hline Per cent correctly predicted a & 82.50 & \\
\hline
\end{tabular}

\section{Discussion}

\section{Socioeconomic characteristics of urban and peri-urban farmers}

Four groups of urban and peri-urban farmers were identified using multivariate analysis (Table 2.3). Multivariate techniques show relationships between different variables and thereby outperform single-criteria classifications. The farmer typology described in our study is similar to Veenhuizen and Danso (2007) and Abdulkadir et al. (2012). Field crop and vegetable farmers are common urban and peri-urban agricultural systems in many developing countries (Drechsel et al., 2006; Pasquini et al., 2010; Abdulkadir et al., 2012). However, ornamental-plant growers were not included in previous studies because it is a relatively new urban-farming system and/or the previous classifications were based on only one or a few criteria (e.g. income or crop type) (Drechsel et al., 2009; Pasquini et al., 2010). The four groups of farmers were different in terms of farm characteristics, livelihood strategies and soil fertility management. Ornamental-plant and vegetable growers had better access to financial, physical, social and human assets (Table 2.3), but they had very small land sizes due to urban encroachment. Ornamental-plant and vegetable producers had better access to financial and social assets compared to other farmers groups because these farmers are organised into cooperatives and small 
enterprises. Ornamental-plant and vegetable producers had also better educational status that helps them to utilize the available resources (e.g. credit, extension services). Due to shortage of land, ornamental-plant and vegetable production systems are more intensive and market-oriented compared to field crop and mixed production. Many field crop farmers had large land sizes and the farmlands were located far from their homestead. Hence, it was difficult to use intensive farm management practices due to the efforts required to transport agricultural inputs (e.g. irrigation water, compost and manure). Market-oriented and intensified vegetable production on small areas of public land has been reported in several countries (Drechsel et al., 2009; Pasquini et al., 2010; Abdulkadir et al., 2012). For example, West African urban farmers produce vegetables on land ranging from 0.07 to 0.41 ha (Abdulkadir et al., 2012); however, the vegetable production is more intensive than those identified in our study. Many field crop farmers used family labour for agricultural activities, while more than $76 \%$ of ornamental-plant and vegetable growers hired additional labour (i.e field crop farmers and unemployed urban dwellers). The family labour reported in this study was very low compared to urban and peri-urban farming systems in West African and Asian countries (De Bon, 2001; Abdulkadir et al., 2012). Hence, a shortage of labour could be another reason for less intensified production in our study. Many urban and peri-urban farmers in the area even lost their land because the land had been taken over for residential or other urban uses. Land acquisition is one of the main constraints for many urban farmers and it impedes the adoption of intensive agricultural practices (Condon et al., 2010, De Bon, 2001). In Ethiopia, land is a public good owned by the state. Therefore, farmers are not allowed to sell their land or use it as collateral to obtain credit (Gittleman, 2009). This land tenure system discourages many urban farmers from investing in their farmland and generating more revenue. We observed that many urban farmers escaped the land tenure trap through intensified production systems close to their homestead. This implies that field crop producers could shift to more intensified production systems in the future because urban encroachment accelerates in the area.

Ornamental-plant and vegetable growers had more formal education than the other clusters and were more engaged in non-farm activities. Some field crop producers were also engaged in unskilled non-farm activities, for instance as night watchmen or labourers. The contribution of non-farm activities to household income was moderate to high in the area. Low income from agriculture is the main reason for many farmers of the other groups to be involved in non-farm activities. Furthermore, the high rate of urbanisation in the study area ( $>4 \%$ per year) creates job opportunities for many farmers outside agriculture. In agreement with our findings, De Bon (2001) and Tittonell et al. (2010) reported a significant contribution of non-farm activities to household income in East African countries. However, the contribution of non-farm activities to household income was very low in West African countries (Abdulkadir et al., 2012). The observed 
differences between Western African farmers and our respondents suggest the need for site-specific classification of farmers to understand their livelihood strategies and design agricultural policies.

\section{Soil fertility management practices}

Soil fertility management practices varied significantly between groups of farmers. The application of manure and compost was very limited in the area. Inorganic fertilisers were the main sources of plant nutrients. Ornamental-plant and vegetable production demands a high nutrient input and consequently rapid economic returns, hence the highest application of organic amendments and irrigation practices were observed in these production systems. The high soil organic carbon content on vegetable farms compared to other farms (Table 2.5) also supported relatively high use of organic amendments in vegetable production. We also observed that only vegetable producers and few farmers who practised mixed farming used irrigation because many vegetable farms were located near the farmers' homesteads or close to rivers or main roads, and for that reason were suitable for irrigation. Irrigation with wastewater is the main source of plant nutrients in many urban and peri-urban agricultural systems (Khai et al., 2007; Abdulkadir et al., 2013). According to Khai et al. (2007), wastewater represents 21 to $61 \%$ and 31 to $66 \%$ of total $\mathrm{N}$ and $\mathrm{K}$ inputs respectively in small-scale peri-urban vegetable production systems in Southeast Asia. In total $21 \mathrm{~kg} \mathrm{~N}^{-1} \mathrm{yr}^{-1}, 2.4 \mathrm{~kg} \mathrm{P}^{-1} \mathrm{yr}^{-1}$ and 55 $\mathrm{kg} \mathrm{K} \mathrm{ha-1} \mathrm{yr}^{-1}$ respectively were added on vegetable farms from irrigation water in the area. This is equivalent to $11-15 \%, 5-8 \%$ and $70-85 \%$ of total $\mathrm{N}, \mathrm{P}$ and $\mathrm{K}$ inputs respectively. As a result, partial $\mathrm{N}$ and $\mathrm{P}$ balances were more positive on vegetable farms due to high use of organic amendments and irrigation with wastewater. The negative $\mathrm{N}$ balance on field crop and mixed farms could result from the application of inorganic fertilisers below the recommended rate due to their high price (Kassie et al., 2009) and insufficient application of organic amendments. Only $9 \%$ of field crop farmers applied manure and/or retained crop residues on farmlands (Table 2.4), and the application rate of manure and/or crop residues was very low $\left(<1 \mathrm{t} \mathrm{ha}^{-1} \mathrm{yr}^{-1}\right)$. In agreement with this, Baudron et al. (2014) reported a limited application of manure on cropland in subSaharan Africa (423 kg ha-1). Loss of nitrogen through leaching following heavy rainfall could be another reason for the negative $\mathrm{N}$ balance. Urea and di-ammonium phosphate were the only inorganic fertilisers available to the farmers. Hence, negative $\mathrm{K}$ balances were observed in all urban and peri-urban production systems. Irrigation water and organic amendments were the main sources of $K$ on vegetable farms. However, even then the partial balance for $\mathrm{K}$ remained negative in these production systems probably due to large exports of $\mathrm{K}$ with the edible parts of vegetables. Comparable negative $\mathrm{K}$ balances were reported by Wang et al. (2008), Diogo et al. (2010) and Abdulkadir et al. (2013) in urban farming systems. In contrast to our study, Khai et al. (2007), Wang et al. 
(2008), Diogo et al. (2010) and Abdulkadir et al. (2013) reported surpluses of $\mathrm{N}$ and P under different urban farming systems due to the intensive use of irrigation water, inorganic fertilisers and organic amendments. The negative nutrient balance in our study but positive nutrient balances in these four other studies under similar production systems are probably due to variations in farm characteristics, level of intensification and livelihood assets. For example, long farm distance, lack of landownership, shortage of irrigation water and less access to extension services and financial support (Table 2.3) influenced our respondents' input use and technology choice. Less intensified cropping system and high competition for the uses of agricultural waste could be another reason for limited application of manure and crop residues on soils (see below) and thereby results in negative nutrient balances in the study area. Therefore, site-specific analysis of nutrient balances is deemed crucial because farmers with a similar production orientation could have different input uses and soil fertility management strategies. Our nutrient balance study also highlighted the need to increase nutrient inputs in urban production systems in some developing countries.

\section{Agricultural-waste utilisation}

This study shows that soil fertility issues are one of the main challenges for urban and peri-urban smallholder farmers in Ethiopia. About $75 \%$ of the respondents observed nutrient limitation on their farmlands, and over $78 \%$ of the respondents even perceived retention of agricultural waste on farmlands as the most viable option to improve soil fertility. However, very small fractions of agricultural waste were allocated to soil amendment in field crop and mixed farming systems. Although we observed that few farmers retained agricultural waste on farmlands, the quantities applied per area is too small to provide significant benefits for soil fertility improvement (Table 2.5 and Fig. 2.3). Our results showed that ornamental-plant growers and vegetable producers utilised over $40 \%$ of manure and crop residues for soil amendment whereas field crop farmers and mixed farming allocated less than $10 \%$ of manure and crop residues to soil amendment. Interestingly, field crop farmers utilised over $75 \%$ of manure for fuel and $80 \%$ of crop residues for feed. The observed variations in allocation of agricultural waste could be due to differences in farm characteristics (Table 2.6) and production goals. Ornamental-plant and vegetable production demands a high nutrient input; hence, higher fractions of agricultural waste are allocated to soil fertility management. In agreement with our findings, Valbuena et al. (2015) observed strong competition for the use of crop residues for soil amendment even under low levels of cereal production systems in sub-Saharan and South Asian countries. In general, intensified production systems (e.g. ornamental and vegetable production systems) and farmers with better access to livelihood assets utilise agricultural waste mainly for soil amendment. For example, shortage of labour and insecure landownership impeded many field crop 
farmers from using agricultural waste for soil amendment (Table 2.6) because land acquisition is the main challenge, which prevents farmers from investing in their farmlands (Kassie et al., 2009). Field crop farmers had large farm size (Table 2.3) and the farms are located far away. As a result, these farmers allocated manure and crop residues mainly to household consumption because a large investment is required to transport agricultural waste. High cattle density in field crop production systems (Table 2.3) could be another reason to retain only a small fraction of crop residues on farmlands. Extension services and compost experience also influenced utilisation of agricultural waste for soil amendment, probably due to increasing farmers' awareness about the benefits of organic amendments. Similarly, Jaleta et al. (2014) described the significant influence of extension services on the retention of crop residues on farmland in Ethiopia.

The current use of agricultural waste observed in our study is consistent with Baudron et al. (2014) and Rimhanen and Kahiluoto (2014) who reported retention of < $10 \%$ of crop residues on croplands in rural parts of Ethiopia. Similarly, over $80 \%$ of crop residues were utilised for feed and less than $20 \%$ of crop residues retained on farmlands in sub-Saharan and South Asian counties (Valbuena et al., 2015). In our study, cattle density is higher compared to farmers in sub-Saharan and South Asia (Abdulkadir et al., 2012; Baudron et al., 2014; Valbuena et al., 2015); however, our respondents applied lower amounts of manure on their farmlands $\left(<1 \mathrm{t} \mathrm{ha}^{-1} \mathrm{yr}^{-1}\right)$. Low manure production, lack of experience and less efficient collection of manure are the causes for the minimum allocation of manure on farmlands (Tittonell et al., 2005). In addition to these factors, our results together with previous studies (Baudron et al., 2014; Rimhanen and Kahiluoto, 2014; Valbuena et al., 2015) indicate that high competition for agricultural waste is the major cause for the slow and low adoption of organic amendments in many developing countries. We found high competition of agricultural waste with other uses such as fuel and feed. The use of manure and crop residues for fuel could continue into the future because other energy sources (kerosene and electricity) are not affordable and/or accessible for many resource-poor farmers. High rates of deforestation in Ethiopia also limit access to fuel wood (Damte et al., 2012), which might further increase the use of manure and crop residues as an energy source. Haileselassie et al. (2006) and Mekonen and Kohlin (2009) also reported on the limited use of manure as a soil amendment due to its consumption for household fuel in rural Ethiopia. Interestingly, many urban dwellers in Ethiopia use cattle dung as fuel, probably due to high poverty in urban areas. Demand for animal dung as fuel creates market opportunities for many urban farmers to sell cattle dung to nearby markets. Income diversification through the sale of cattle dung in rural areas of Ethiopia has been reported (Amsalu et al., 2007). Maize and sorghum straw are mainly used for fuel, while small-sized residues are used for animal feed in the area. Consistent with this, several studies showed the use of crop residues for energy and animal feed in developed and developing countries (Scarlat et al., 2010; Baudron et al., 
2014; Jaleta et al., 2014). Crop residues, especially from teff (Eragrostis tef), are also used as building material in many parts of Ethiopia. As a result, the high demand for building material creates market opportunities for many field crop farmers to sell their residues. Hence, our results suggest that the existing competition in the uses of agricultural waste should be considered for sustainable soil fertility management. Furthermore, technology interventions are recommended that encourage households to use other sources of fuel such as fuel wood, so that agricultural waste could be used as a soil amendment. The possible solutions that could encourage farmers to use agricultural waste for soil amendment will be discussed in the next section.

\section{Demand for urban-waste compost}

Our study shows a high demand for urban waste compost among urban farmers. About $58 \%$ of the respondents were willing to accept urban waste as soil amendment. Many respondents were also willing to work at least for eight days per year in waste treatment plants. Consistent with this finding, 70\% of farmers in Yaoundé, Cameroon (Folefack, 2005) and over $80 \%$ of farmers in Ghana (Danso et al., 2006) were interested to contribute money for urban-waste compost. In our study, the respondents bid very small amounts of money for urban-waste compost compared with the previous studies (Folefack, 2005; Danso et al., 2006) who reported more than 1 US\$ for $50 \mathrm{~kg}$ compost. However, the current bids were almost twice as high as previous studies when labour is converted into a monetary value using the current market wage rate. Our result implies that researchers should consider labour in addition to money to estimate willingness-to-pay for compost demand in developing countries. It is important to note that resource-poor farmers expressed their compost demand via a willingness to contribute labour because labour is more readily available and cheaper than cash in many developing countries.

The present study confirmed that the demand for urban waste compost varied between different urban farming systems and farm characteristics. The highest demand for urban waste compost was observed from ornamental-plant growers and vegetable producers because these production systems require a high nutrient input and consequently need rapid economic returns. In contrast, field crop producers showed less interest in urban waste compost, probably due to high distance from urban areas, insecure landownership, land size and less access to extension services. The econometric output also showed that farmers with a higher educational status and better access to extension services were more willing to participate in urban waste compost because these variables are important to increase farmers' awareness about the benefits of compost (Danso et al., 2006). Education also helps farmers to utilise existing resources in a better way and to create new assets and opportunities (Messer and Townsley, 2003). Furthermore, large investments are required for field crop producers to transport urban waste compost because they have large land size and the farms are located a large 
distance from urban areas. The land tenure system also influences field crop farmers' willingness to participate in urban-waste compost because insecure landownership discourages farmers from investing in their farmlands (Kassie et al., 2009). In agreement with this, Folefack (2005) and Danso et al. (2006) also identified transport costs and insecure landownership as constraints for compost demand.

\section{Implications for intensification and urban waste management}

Integrated use of inorganic fertilisers with organic amendments may often not be possible in developing countries without increasing the quantity of agricultural waste retained in the fields. Utilisation of agricultural waste for soil amendment is limited in many developing countries due to low levels of crop production and high biomass demand for feed (Valbuena et al., 2015), maintaining a vicious circle of low inputs of organic resources and low outputs as crop residues produced. Intensification of crop and livestock production could be the best option to feed the livestock as well as utilise crop residues for soil amendment. For example, we observed that intensified vegetable production satisfied the demand for feed as well as for soil amendment. Intensification of vegetable production in the study area is the result of multiple cropping cycles (i.e. at least three cycles per year), irrigation, access to agricultural inputs and functional financial and market institutions. On the other hand, less intensified cropping systems increase the pressure on crop residues especially during the dry season when alternative feed resources are scarce. Similarly, Valbuena et al. (2015) found that high levels of crop production in India and Bangladesh provide sufficient amounts of crop residues for feed and soil even in areas where alternative feed resources are limited. Closing the yield gap is essential to increase the quantity of crop residues retained for soil amendment (Baudron et al., 2014). This could be achieved by increasing the quantity of nutrient applied, using improved crop varieties and controlling yield reducing factors such as weed, pests and diseases.

Livestock intensification could increase the amount of crop residues used for soil amendment because high levels of livestock production require energy-rich supplements such as high-value forage and agro-industrial by-products rather than crop residues (Baudron et al., 2014). Livestock intensification also increases the amount of manure produced and thereby large quantities of manure could be applied on crop fields resulting in positive nutrient balances (Abdulkadir et al., 2013; Vu et al., 2012). Intensification of livestock production results in surplus $\mathrm{N}, \mathrm{P}$ and $\mathrm{K}$ balances in agriculture and agriculture-aquaculture systems (fresh-rice and orchard system) in Asia and African countries (Abdulkadir et al., 2013; Vu et al., 2012). While intensified livestock production could lead to pollution of the environment and loss of plant nutrients if manure management is inappropriate, this potential problem could be resolved by using simple biogas production technology ( $\mathrm{Vu}$ et al., 2012) and by 
improving flooring and roofing of the stall. In our study area, we observed that farmers without cropland but with intensified livestock production have a problem of manure handling. Therefore, creating linkages between intensified livestock farmers and crop producers could increase the amount of manure applied on farmlands.

Farm characteristics and socioeconomic conditions impede agricultural intensification in developing countries (Baudron et al., 2014; Valbuena et al., 2015). We identified that insecure land ownership, shortage of land, limited access to agricultural inputs and to functional finance and market institutions and extension services are the major challenges for crop and livestock intensification in the area. Hence, it is essential to improve the existing policies, infrastructure, extension services, markets and financial institutions to encourage intensification of crop and livestock production so that the pressure on agricultural waste could be reduced in developing countries.

Urban waste composting is another viable option to increase soil fertility in urban farming systems where utilisation of agricultural waste for soil amendment is limited. A large amount of urban waste is produced every day; however, the majority of waste is dumped in landfills in both developed and developing countries (Regassa et al., 2011; Mengistu, 2013; Guerrero et al., 2013; Bernad - Beltrán et al., 2014). Large proportions of urban waste in the study area as well as in many countries are organic which could provide an opportunity to recycle urban waste in to compost (Xiao et al., 2007; Mengistu, 2013; Bernad-Beltrán et al., 2014). However, less than 5\% of urban waste is converted to compost in the study area (Mengistu, 2013), and even in some developed countries (e.g Beijing, China) (Xiao et al., 2007). We suggest small and decentralized community composting facilities because large and centralized composting plants require high operational, maintenance, and transportation costs. Small-scale composting plants create jobs for the urban poor and empower women. Urban waste composting involves a large number of different stakeholders. However, many urban waste composting facilities in the area and developing countries often face problems due to lack of organisation, infrastructure, involvement of stakeholders and financial resources (Guerrero et al., 2013).

\section{Conclusions}

The integrated use of mineral fertilisers and organic amendments is the most sustainable option to increase agricultural production and soil organic matter. However, very small fractions of agricultural waste are allocated for soil amendment. We suggest that competition for agricultural waste between fuel, feed and soil amendment is a major cause of nutrient deficits in the urban and peri-urban production systems. Agricultural waste is mainly used for feed, fuel and income source. Hence, current soil fertility management strategies should consider that competition for the allocation of agricultural 
waste. Furthermore, replacement of fuel and feed through sustainable means other than farm waste is crucial, as a consequence of which agricultural waste could be used as soil amendment. Urban-waste compost could also be an alternative soil amendment for urban and peri-urban agriculture. The re-use of biodegradable urban waste for soil amendment is an imperative in many developing countries. Hence, education and creation of awareness about urban-waste compost are required. The involvement and commitment of stakeholders are also essential because considerable investments are required to utilise urban waste for soil amendment. Finally, we suggest that both labour and cash should be considered when estimating willingness-to-pay for compost.

\section{Acknowledgements}

This research was funded by the AgTraIn (Agricultural Transformation by Innovation) Erasmus Mundus Joint Doctoral programme. The authors acknowledge Prof. Lijbert Brussaard, Dr. Sander Bruun and three anonymous reviewers for their valuable comments on earlier versions of the manuscript. Our special thanks go to Biruk Abdissa for his assistance during fieldwork. 


\section{CHAPTER 3}

\section{Vermicomposting as a technology for reducing nitrogen losses and greenhouse gas emissions from small-scale composting}

This chapter is published as:

Nigussie, A., Kuyper, T.W., Bruun, S., de Neergaard A. (2016). Vermicomposting as a technology for reducing nitrogen losses and greenhouse gas emissions from smallscale composting. Journal of Cleaner Production 139, 429-439. 


\title{
Vermicomposting as a technology for reducing nitrogen losses and greenhouse gas emissions from small-scale composting
}

\begin{abstract}
Thermophilic composting produces a significant amount of greenhouse gases. The objectives of this study were (i) to evaluate the effectiveness of vermicomposting to reduce nitrogen losses and greenhouse gases emissions compared to thermophilic composting, and (ii) to determine the effect of different variables (i.e. carbon : nitrogen ratio, earthworm density, moisture content and carbon quality) on greenhouse gases emissions and earthworm growth during vermicomposting. The results showed that vermicomposting significantly reduced nitrogen loss by $10-20 \%$ compared to thermophilic composting. Vermicomposting decreased nitrous oxide emissions by 25$36 \%$ and methane emissions by $22-26 \%$. A higher earthworm density increased carbon dioxide emissions by $3-14 \%$, but decreased methane emissions by 10-35\%. Earthworm density had a marginal effect on nitrous oxide emissions. Vermicomposting decreased nitrous oxide emissions by $40 \%$ with higher moisture and by $23 \%$ with lower moisture. Vermicomposting also decreased methane emissions by $32 \%$ and $16 \%$ with higher and lower moisture respectively. This study showed that the addition of labile carbon sources increased carbon dioxide and methane emissions and earthworm growth, but did not affect nitrous oxide emissions. In conclusion, vermicomposting is effective at reducing nitrogen losses and greenhouse gas emissions from composting. Therefore, vermicomposting could represent an option for reducing greenhouse gas emissions from composting, particularly in developing countries where the existing technical solutions are expensive and difficult to implement.
\end{abstract}

Keywords: thermophilic composting, vermicomposting, substrate quality, earthworms 


\section{Introduction}

Municipal solid waste management has become a matter of global concern due to rapid urban population growth and the high costs associated with waste management (Marshall and Farahbakhsh, 2013). Studies have shown that biodegradable materials constitute over half of municipal solid waste (Taeporamaysamai and Ratanatamskul, 2016), with their results indicating that bioconversion of municipal solid waste into soil amendments (compost) is a viable option for sustainable waste management. High compost demand by urban farmers (Nigussie et al., 2015) also emphasises the need for municipal waste composting.

Thermophilic composting and vermicomposting are effective techniques commonly used to convert biodegradable waste into soil amendments. Thermophilic composting is a composting process at high temperatures $\left(>45^{\circ} \mathrm{C}\right)$, but vermicomposting is a mesophilic $\left(<30{ }^{\circ} \mathrm{C}\right)$ process that involves earthworms and associated microorganisms in decomposing and stabilising organic materials (Lim et al., 2016). Major similarities and differences between thermophilic composting and vermicomposting are summarised by Lim et al. (2016).

Compost, particularly in many (sub-) tropical countries, contains low amounts of plant nutrients (especially nitrogen) and hence is unable to meet crop nutrient requirements. Nitrogen $(\mathrm{N})$ is lost during composting through ammonia $\left(\mathrm{NH}_{3}\right)$, nitrogen oxides $\left(\mathrm{NO}_{x}\right)$, nitrous oxide $\left(\mathrm{N}_{2} \mathrm{O}\right)$ or dinitrogen $\left(\mathrm{N}_{2}\right)$ (Awasthi et al., 2016; Chan et al., 2016). The total $\mathrm{N}$ loss may account for $40-70 \%$ of initial $\mathrm{N}$ (Vu et al., 2015). These $\mathrm{N}$ losses reduce the fertilising value of compost and contribute to environmental problems. Furthermore, significant greenhouse gas (GHG) emissions (methane and nitrous oxide) from thermophilic composting are widely reported (Lim et al., 2016). Anoxic hotspots in the compost piles produce methane $\left(\mathrm{CH}_{4}\right)$, while nitrification in aerobic microsites and denitrification in anaerobic microsites are responsible for $\mathrm{N}_{2} \mathrm{O}$ production (Chan et al., 2011).

Moisture, temperature, $\mathrm{pH}$, ammonium concentration and substrate $\mathrm{C}: \mathrm{N}$ ratio are the key factors that control $\mathrm{N}$ losses and GHG emissions from thermophilic composting (Chowdhury et al., 2014; Santos et al., 2016). Temperatures above $45{ }^{\circ} \mathrm{C}$ increase $\mathrm{NH}_{3}$ volatilisation and a high $\mathrm{pH}$ (about 9; $\mathrm{pKa}=9.25$ ) shifts the $\mathrm{NH}_{4}{ }^{+}=\mathrm{NH}_{3}$ equilibrium to ammonia (Chowdhury et al., 2014). High temperatures also inhibit the nitrification process and thereby increase ammonia volatilisation. About $36-70 \%$ of total $\mathrm{N}$ losses have been observed during the active stage of thermophilic composting (Chowdhury et al., 2014). High oxygen consumption during the active stage leads to anoxic microsites, which are centres of GHG production. Similarly, high activities of methanogens (Ermolaev et al., 2014) and subsequent $\mathrm{CH}_{4}$ emissions ( $\mathrm{Vu}$ et al., 2015) have been reported during the thermophilic stage. Controlling $\mathrm{pH}$ through the use of additives (Awasthi et al., 2016), lowering mineralisable $C$ and/or increasing the substrate $C: N$ 
ratio by the addition of a bulking agent (Santos et al., 2016; Wang et al., 2014) reduce N losses and GHG emissions. However, these practices are difficult to scale up to largescale systems, particularly in non-mechanised agricultural systems. Furthermore, it is a challenge to implement these practices under field conditions where there is shortage of labour. Vermicomposting, a mesophilic $\left(<30^{\circ} \mathrm{C}\right)$ composting technique, might therefore be a good alternative for reducing $\mathrm{N}$ losses and GHG emissions.

Earthworms improve air circulation in the compost pile through continuous turning of substrate, thereby maintaining aerobic conditions. They also affect $\mathrm{N}$ transformations such as mineralisation, volatilisation, nitrification and denitrification through their interaction with associated microbes (Velasco-Velasco et al., 2011; Wang et al., 2014). Hence, earthworms could influence $N$ losses and GHG emissions during composting. Little is known about $\mathrm{N}$ losses and GHG emissions during vermicomposting (Lim et al., 2016), and the literature is contradictory. For instance, Wang et al. (2014) found that earthworms reduce GHG emissions during vermicomposting. Other studies have shown that earthworms induce $\mathrm{N}_{2} \mathrm{O}$ emissions (Hobson et al., 2005) because their gut contains denitrifying bacteria. Hence, the effects of earthworms on $\mathrm{N}$ loss and GHG emissions require clarification. Moreover, previous studies have not considered variables such as mineral $\mathrm{N}$ concentration, $\mathrm{C}$ quality, moisture content and earthworm density, which could influence $\mathrm{N}$ loss and GHG emissions from vermicomposting. The mineral nitrogen and available $C$ contents influence the denitrification processes in the earthworm gut (Lubbers et al., 2013). It is therefore essential to understand the effect of earthworms on $\mathrm{N}_{2} \mathrm{O}$ emissions from materials with different substrate quality (i.e. C:N ratio, labile $\mathrm{C}$ sources such as glucose). Moisture is another factor that determines the magnitude of GHG emissions (Jiang et al., 2011), since higher moisture content increases anaerobic patches in the compost pile that result in greater GHG emissions. However, there are no data on the effect of earthworms on GHG emissions with varying moisture contents. Studies have shown that a higher earthworm density increases $N$ transformation (Ndegwa et al., 2000). Earthworm density could also influence the mixing of substrates - aeration - and subsequently influence GHG emissions. Hence, the objectives of the present study were: (i) to evaluate the effectiveness of vermicomposting in reducing $\mathrm{N}$ losses and GHG emissions compared with thermophilic composting, and (ii) to determine the effect of substrate C:N ratio, earthworm density, carbon quality and moisture on GHG emissions from vermicomposting. It was hypothesised that (i) vermicomposting decreases $\mathrm{N}$ losses and $\mathrm{N}_{2} \mathrm{O}$ and $\mathrm{CH}_{4}$ emissions compared to thermophilic composting, (ii) higher earthworm density reduces $\mathrm{CH}_{4}$ and $\mathrm{N}_{2} \mathrm{O}$ emissions from vermicomposting, and (iii) the addition of labile carbon (glucose) increases $\mathrm{CH}_{4}$ and $\mathrm{N}_{2} \mathrm{O}$ emissions from vermicomposting, with the effect of glucose being greater at higher moisture content of the compost. 


\section{Materials and Methods}

\section{Experimental set-up}

Three experiments were each carried out for 45 days each. The first experiment (Experiment I) was undertaken to quantify total $\mathrm{N}$ loss and GHG emissions from two different composting methods as affected by the substrate $\mathrm{C}: \mathrm{N}$ ratio. The composting experiment was carried out in small-scale reactors at the University of Copenhagen, Denmark using vegetable waste. Details of the reactors are described below and illustrated in Figure 3.1. Two composting methods, namely thermophilic composting and vermicomposting, and two $\mathrm{C}: \mathrm{N}$ ratios (24 and 30) were used (Table 3.1). The experimental design was a complete random design arranged in a $2 \times 2$ factorial arrangement, and the treatments were replicated three times. The reactors were rotated every week to reduce the effect of external variables on the composting processes. The two C:N ratios were chosen after a pilot study showed that C: $\mathrm{N}$ ratios between 24 and 30 were optimal for both composting methods with the substrates used. Only a small number of earthworms survived $(<43 \%)$ when the C:N ratio was below 24 , possibly due to the high moisture content in vegetable waste (87-91\%) creating anaerobic conditions in the reactors. Thermophilic conditions $\left(>45^{\circ} \mathrm{C}\right)$ could not be achieved when the substrate $\mathrm{C}: \mathrm{N}$ ratio was above 30 .

The second experiment (Experiment II) was undertaken to determine the effect of earthworm abundance on GHG emissions from vermicomposting. Four different substrates and two earthworm densities (i.e. $1 \mathrm{~kg}$ earthworm $\mathrm{m}^{-2}$ and $3 \mathrm{~kg}$ earthworm $\mathrm{m}^{-}$ $\left.{ }^{2}\right)$ were used. The results were analysed using a complete random design in a $4 \times 2$ factorial arrangement.

The third experiment (Experiment III) was conducted to test whether easily degradable $\mathrm{C}$ substrate (glucose) reduces $\mathrm{N}_{2} \mathrm{O}$ emissions from vermicomposting by immobilisation of mineral nitrogen and/or increases $\mathrm{CH}_{4}$ emissions, since labile $\mathrm{C}$ pools could be used by methanogenic microorganisms. Consequently, two levels of available $\mathrm{C}$ (i.e. with and without the addition of glucose) and two moisture levels (i.e. $75 \%$ and $85 \%$ ) in the presence or absence of earthworms were applied. The experimental design was a complete random design arranged as a $2 \times 2 \times 2$ three-way factorial experiment with three replicates. The details of these experiments are presented below. 


\section{Experiment I}

\section{Composting materials}

Vegetable waste, a representative household waste in many countries, was collected from a food-processing plant in Denmark. The vegetable waste consisted of a mixture of carrot, cabbage, lettuce and red beet. It contained $87-91 \%$ moisture, total carbon of $400-$ $410 \mathrm{~g} \mathrm{~kg}^{-1}$ dry matter, total nitrogen of $15-35 \mathrm{~g} \mathrm{~kg}^{-1}$ dry matter, $1.4-2.6 \mathrm{~g} \mathrm{NH}_{4}^{+} \mathrm{kg}^{-1}$ dry matter and 0.2-0.4 $\mathrm{g} \mathrm{NO}^{-} \mathrm{kg}^{-1}$ dry matter. The variation in nitrogen content between the different components was used to vary the $\mathrm{C}: \mathrm{N}$ ratio, with minimum changes in other properties such as moisture content. Dry barley straw was chopped to $<2 \mathrm{~cm}$ pieces and mixed thoroughly with the vegetable waste in two ratios, namely 5:1 and 10:1 (vegetable : straw), to produce the intended C:N ratios. The barley straw had $5 \%$ moisture content, total carbon content of $441 \mathrm{~g} \mathrm{~kg}^{-1}$ dry matter and total nitrogen content of $9 \mathrm{~g} \mathrm{~kg}^{-1}$ dry matter. The chemical properties of substrates used for the experiments are presented in Table 3.1.

Table 3.1. Selected chemical properties of the starting materials used for the composting experiment

\begin{tabular}{|c|c|c|c|c|c|c|c|}
\hline Treatment code & $\begin{array}{l}\text { Mixing ratio }{ }^{1} \\
\text { (vegetable: straw) }\end{array}$ & Total C & Total N & $\mathrm{C}: \mathrm{N}$ & $\mathrm{NH}_{4}{ }^{+}$ & $\mathrm{NO}_{3}^{-}$ & $\mathrm{pH}$ \\
\hline \multicolumn{8}{|l|}{ Experiment I } \\
\hline & & \multicolumn{3}{|c|}{------- $\mathrm{g} \mathrm{kg}^{-1} \mathrm{DM}----$} & \multicolumn{3}{|c|}{------- $\mathrm{mg} \mathrm{kg}^{-1} \mathrm{DM}$------- } \\
\hline Mix A & $5: 1$ & 443.8 & 14.5 & 30.6 & 6220.5 & 91.5 & 8.4 \\
\hline Mix B & $10: 1$ & 425.9 & 17.9 & 23.8 & 8160.5 & 119.7 & 8.2 \\
\hline Experiment II & \multicolumn{7}{|c|}{ (vegetable: cattle manure: straw) } \\
\hline Mix A & $5: 0: 1$ & 443.8 & 14.5 & 30.6 & 6220.5 & 91.5 & 8.4 \\
\hline Mix B & 10:0:1 & 425.9 & 17.9 & 23.8 & 8160.5 & 119.7 & 8.2 \\
\hline Mix C & 4:1:0.25 & 391.4 & 19.5 & 20.1 & 1038.8 & 269.0 & 7.2 \\
\hline Mix D & 3:1:0 & 382.1 & 26.6 & 14.2 & 1440.3 & 478.0 & 6.6 \\
\hline
\end{tabular}

${ }^{1}$ wet basis; $\mathrm{C}=$ carbon; $\mathrm{N}$ = nitrogen; $\mathrm{DM}=$ dry matter

\section{Thermophilic composting}

The thermophilic composts were prepared in 60-litre polyethylene compost reactors. The reactors were insulated with a 5-cm foam layer in order to minimise heat loss. Perforated plastic tubes $3 \mathrm{~cm}$ in diameter were positioned at 10, 15 and $20 \mathrm{~cm}$ height to ensure natural air ventilation in the reactor. Two plastic tubes $(3 \mathrm{~cm}$ in diameter) were also connected to the reactor headspace to circulate air in the reactor (Fig. 3.1a). Five kg (wet basis) substrate was then applied to the reactors and the moisture content was adjusted to $50-60 \%$ by spraying water. The mixtures were turned every two days in the first week and once a week until the end of the experiment. 


\section{Vermicomposting}

The same substrates were used for vermicomposting, but in 36-litre polyethylene containers ( $30 \mathrm{~cm}$ width $\times 40 \mathrm{~cm}$ length $\times 30 \mathrm{~cm}$ height) (Fig. 3.1b). Different-sized containers were used because the containers for the thermophilic composting also included the headspace (approximately $24 \mathrm{~L}$ ). The containers were otherwise filled to the same degree in both composting methods. A $10 \mathrm{~cm}$ diameter hole was also made in the lids of the containers to ensure air circulation in the vermicompost bin. A $3 \mathrm{~cm}$-wide Velcro® tape was glued to the top of the container to prevent the escape of earthworms.
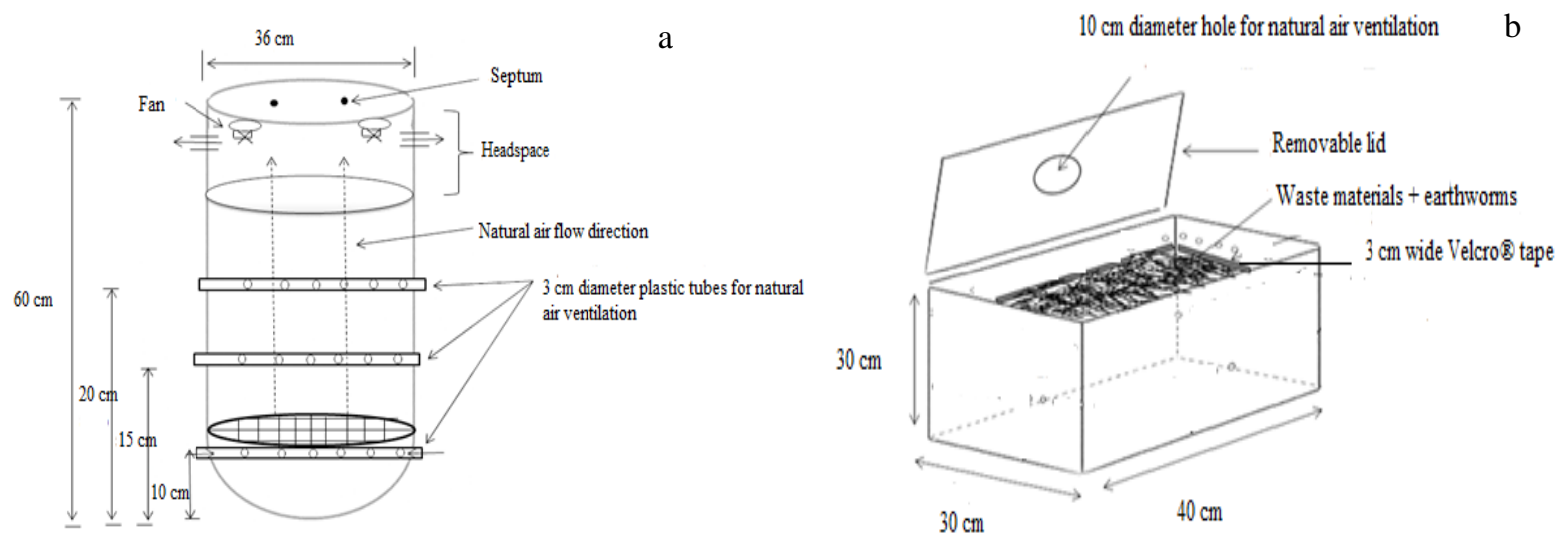

Figure 3.1. The reactor design: (a) thermophilic composting, (b) vermicomposting. The reactor for thermophilic composting was adopted from Vu et al. (2014).

Prior to earthworm addition, one $\mathrm{kg}$ (wet basis) straw pellets $(<1 \mathrm{~cm})$ were added for

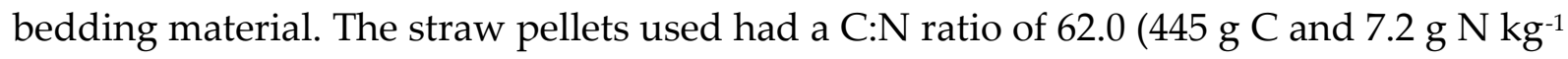
dry matter) and a $\mathrm{pH}$ value of 7.2. Pre-decomposed cattle manure ( $273 \mathrm{~g} \mathrm{C}$ and $21.2 \mathrm{~g} \mathrm{~N}$ $\mathrm{kg}^{-1}$ dry matter) was also mixed with the straw pellets to create habitats for the earthworms. The same amount of straw pellets and pre-decomposed cattle manure was added to the thermophilic composting reactors in order to provide the same substrate.

Adult Eisenia fetida was used for the experiment. The earthworms were kept on moist paper at $15^{\circ} \mathrm{C}$ for $24 \mathrm{~h}$ to empty their guts prior to being weighed and put in the vermicomposting bins. The earthworms were then added to each vermicomposting reactor at the stocking rate of $3 \mathrm{~kg}$ earthworm $\mathrm{m}^{-2}$ (i.e. equivalent to $360 \mathrm{~g}$ earthworms per container). A continuous-flow vermicomposting system was used because it is the most commonly used vermicomposting method in small-scale systems (Abbasi et al., 2015). This means that the bedding materials were put in first, then inoculated with earthworms, and finally covered continuously with $10-15 \mathrm{~cm}$ layers of waste. The first half (i.e. $2.5 \mathrm{~kg}$ of substrate) was added at the start of the experiment, and the other half added after two weeks. The moisture content in the vermicompost reactors was kept at $80-85 \%$ by occasional spraying of water. The temperatures in the thermophilic and 
vermicompost reactors were recorded every two hours using a temperature data logger (Tinytag View 2-TV-4020, United Kingdom).

\section{Experiment II}

Four different substrates were prepared from vegetable waste, pre-decomposed cattle manure (273 g C and $21.2 \mathrm{~g} \mathrm{~N} \mathrm{~kg}^{-1}$ dry matter) and barley straw (Table 3.1). The vermicomposting was prepared as described in Experiment I. In this study, however, adult Eisenia fetida were added at two stocking densities, namely $1 \mathrm{~kg} \mathrm{~m}^{-2}$ and $3 \mathrm{~kg} \mathrm{~m}^{-2}$, equivalent to $120 \mathrm{~g}$ and $360 \mathrm{~g}$ earthworms per container respectively.

\section{Experiment III}

A mixture of vegetable waste and pre-decomposed cattle manure was selected for this experiment. Glucose (i.e. labile C source) was added at the rate of 5\% (dry weight base). Two moisture contents ( $75 \%$ and $85 \%$ ) were used to determine the relationship between moisture and glucose on GHG emissions during vermicomposting. The earthworms were added at a stocking rate of $3 \mathrm{~kg} \mathrm{~m}^{-2}$. Treatments without the addition of glucose and earthworms were used as controls. The treatments without earthworms were mesophilic (i.e. the temperature was $<45^{\circ} \mathrm{C}$ ) because the mixtures were regularly turned manually. Hence, the treatments without earthworms represented small-scale household aerobic composting (Chan et al., 2011).

\section{Gas sampling}

The gas samples were collected every two days for the first week after the addition of substrates and then twice a week until the end of the experiments. All ventilation tubes on the thermophilic reactors (Fig. 3.1a) were air-tightened with rubber plugs at the time of gas sampling. The vermicompost reactors were placed in an airtight polyethylene container (40 cm width $\times 50 \mathrm{~cm}$ length $\times 40 \mathrm{~cm}$ height) during gas sampling. Two mini fans $(12 \mathrm{~V})$ were installed in all the reactors to ensure homogenous distribution of air in the headspace during sampling. Gas samples were taken using a $60 \mathrm{ml}$ air-tight syringe at five time points (at 0, 20, 40, 60 and 80 minutes) and injected into pre-evacuated $3 \mathrm{ml}$ screw-capped Exetainer ${ }^{\circledR}$ vials. The linearity assumption was checked once a month by collecting gas samples at 0, 20, 40, 60, 80 and 100 minutes. The gas samples were analysed using gas chromatography (Bruker 450-GC 2011, United Kingdom). The $\mathrm{CO}_{2}$ concentration was measured using a thermal conductivity detector (TCD), whereas $\mathrm{N}_{2} \mathrm{O}$ and $\mathrm{CH}_{4}$ were measured using an electron capture detector (ECD) and flame ionisation detector (FID) respectively. The emission rate in $\mathrm{mg} \mathrm{kg}^{-1}$ initial dry matter day-1 was calculated using equation 1 (Czepiel et al., 1996): 
Emission rate $=\left(\frac{\Delta \mathrm{C}}{\Delta \mathrm{t}}\right) *\left(\frac{\mathrm{V}}{\mathrm{A}}\right) *\left(\frac{\mathrm{M}}{\mathrm{Vs}}\right) *\left(\frac{\mathrm{P}}{\mathrm{Po}}\right) *\left(\frac{273}{\mathrm{~T}}\right) * 24 \mathrm{hr} *\left(\frac{\mathrm{A}}{\mathrm{W}}\right)$

where $\Delta \mathrm{C}$ is the change in concentration of gas (ppm) at time interval $\Delta \mathrm{t}$ (hour), $\mathrm{V}$ and $\mathrm{A}$ are the headspace volume (litre) and reactor surface area $\left(\mathrm{m}^{2}\right)$ respectively, $M$ is the molecular mass of the gas of interest (44, 16 and $44 \mathrm{~g}$ for $\mathrm{CO}_{2}, \mathrm{CH}_{4}$ and $\mathrm{N}_{2} \mathrm{O}$ respectively), Vs is the volume occupied by 1 mole of a gas at standard temperature and pressure (22.4 litre), $\mathrm{P}$ is the barometric pressure (bar), $\mathrm{P}_{\mathrm{o}}$ is the standard pressure (i.e. $1.013 \mathrm{bar}$ ), $\mathrm{T}$ is the temperature inside the chamber during the deployment time in Kelvin, and W is the initial dry mass of the composting material $(\mathrm{kg})$.

The cumulative emissions were calculated using the trapezoid formula (equation 2) (Ly et al., 2013):

$$
A_{t(a b)}=\frac{\left(t_{b}-t_{a}\right) \cdot\left(F_{t a}+F_{t b}\right)}{2}
$$

where $A_{t(a b)}$ is the cumulative emission between the measurement days (between $t_{a}$ and $\left.t_{b}\right), t_{a}$ and $t_{b}$ are the dates of the two measurements, and $F_{t a}$ and $F_{t b}$ are the gas fluxes at the two measurement dates.

Therefore, the total cumulative emission was calculated as the sum of cumulative emissions on each day using equation 3:

$$
\text { Total cumulative emission }=\sum \mathrm{A}_{\mathrm{t}(\mathrm{ab})}
$$

The global warming potential ( $\mathrm{CO}_{2}$-equivalents) of each treatment was then calculated by multiplying total cumulative $\mathrm{CO}_{2}, \mathrm{CH}_{4}$ and $\mathrm{N}_{2} \mathrm{O}$ emissions by 1,34 and 298 respectively (IPCC, 2013). Global warming potential was calculated for all three greenhouse gases and for the combination of $\mathrm{CH}_{4}$ and $\mathrm{N}_{2} \mathrm{O}$.

\section{Chemical analyses}

Compost samples were collected for the analyses of $\mathrm{pH}$, total carbon, total nitrogen, $\mathrm{NO}_{3}$ and $\mathrm{NH}_{4}{ }^{+}$. Half of the samples were oven-dried at $40{ }^{\circ} \mathrm{C}$ and milled to determine $\mathrm{pH}$, total carbon and total nitrogen, while the other half was stored in a freezer at $-18^{\circ} \mathrm{C}$ for $\mathrm{NH}_{4}{ }^{+}$and $\mathrm{NO}_{3}{ }^{-}$measurements. The $\mathrm{pH}$ was measured in water $(1: 10$ ratio, w/v). Total carbon and total nitrogen were determined using isotope ratio mass spectroscopy (IRMS). Compost samples were mixed with $1 \mathrm{M} \mathrm{KCl}$ in a 1:100 compost:solution ratio (w/v) and shaken for one hour. The extracts were then analysed for $\mathrm{NH}_{4}{ }^{+}$and $\mathrm{NO}_{3}{ }^{-}$using a flow injection analyser (FIA star TM 5000 analyser, Denmark).

The final and initial total $\mathrm{C}$ and total $\mathrm{N}$ contents were used to calculate the $\mathrm{C}$ and $\mathrm{N}$ mass balances as: 


$$
\text { Relative mass balance }=\frac{Q_{i} C_{i}-Q_{f} C_{f}}{Q_{i} C_{i}} X 100
$$

where $Q_{i}$ and $Q_{f}$ are total dry weight at the beginning and end of the experiments respectively, and $C_{i}$ and $C_{f}$ are carbon or nitrogen concentrations at the beginning and end of the experiments respectively.

\section{Statistical analyses}

The statistical analyses were carried out using the SAS version 9.3 statistical package. Analysis of variance (ANOVA) was used to test the significant sources of variation, and subsequent Tukey test was used to compare the treatment means if the factors' effect was significant at $\mathrm{P}<0.05$. Treatments in Experiments I and II were arranged in a complete random design and two-way ANOVA was performed accordingly. Three-way ANOVA was used in Experiment III. The assumptions of ANOVA were checked before data analysis.

\section{Results}

\section{Comparison of thermophilic compost and vermicompost (Experiment I)}

\section{GHG emissions}

Total cumulative $\mathrm{CO}_{2}$ varied by composting method $(\mathrm{P}<0.01), \mathrm{C}: \mathrm{N}$ ratio $(\mathrm{P}<0.001)$ and their interaction $(\mathrm{P}<0.001)$ (Fig. 3.2). Vermicomposting increased total cumulative $\mathrm{CO}_{2}$ emissions compared with thermophilic composting. The composting method and C:N ratio affected total cumulative $\mathrm{CH}_{4}$ emissions $(\mathrm{P}<0.05$ and $\mathrm{P}=0.04$ respectively). Vermicomposting decreased $\mathrm{CH}_{4}$ emissions by $22 \%$ from high $\mathrm{C}: \mathrm{N}$ and $26 \%$ from low $\mathrm{C}: \mathrm{N}$ compared with thermophilic composting. The higher C:N ratio (addition of straw) decreased $\mathrm{CH}_{4}$ emissions by $13-18 \%(\mathrm{P}=0.04)$. As with $\mathrm{CH}_{4}$ emissions, the composting method and $\mathrm{C}: \mathrm{N}$ substrate affected cumulative $\mathrm{N}_{2} \mathrm{O}$ emissions $(\mathrm{P}=0.05$ and $\mathrm{P}=0.001$ respectively). Vermicomposting decreased $\mathrm{N}_{2} \mathrm{O}$ emissions by $36 \%$ from low C:N substrate and by $25 \%$ from high C:N material.

The total GHG budget for both composting methods and $\mathrm{C}: \mathrm{N}$ ratio is presented in Figure 3.2. Total GHG emissions varied between composting method $(P<0.001)$ and substrate $\mathrm{C}: \mathrm{N}(\mathrm{P}<0.05)$ if $\mathrm{CO}_{2}$ emissions were excluded from the total GHG budget. Accordingly, vermicomposting decreased total GHG emissions by $20-30 \%$ relative to thermophilic composting (Fig. 3.2d). Vermicomposting had a higher total GHG budget than thermophilic composting $(\mathrm{P}<0.001)$ when $\mathrm{CO}_{2}$ was accounted for in the total GHG budget (Fig. 3.2e). The addition of straw reduced total GHG emissions $(\mathrm{P}<0.05)$ in both scenarios (including and/or excluding $\mathrm{CO}_{2}$ from the GHG budget). 

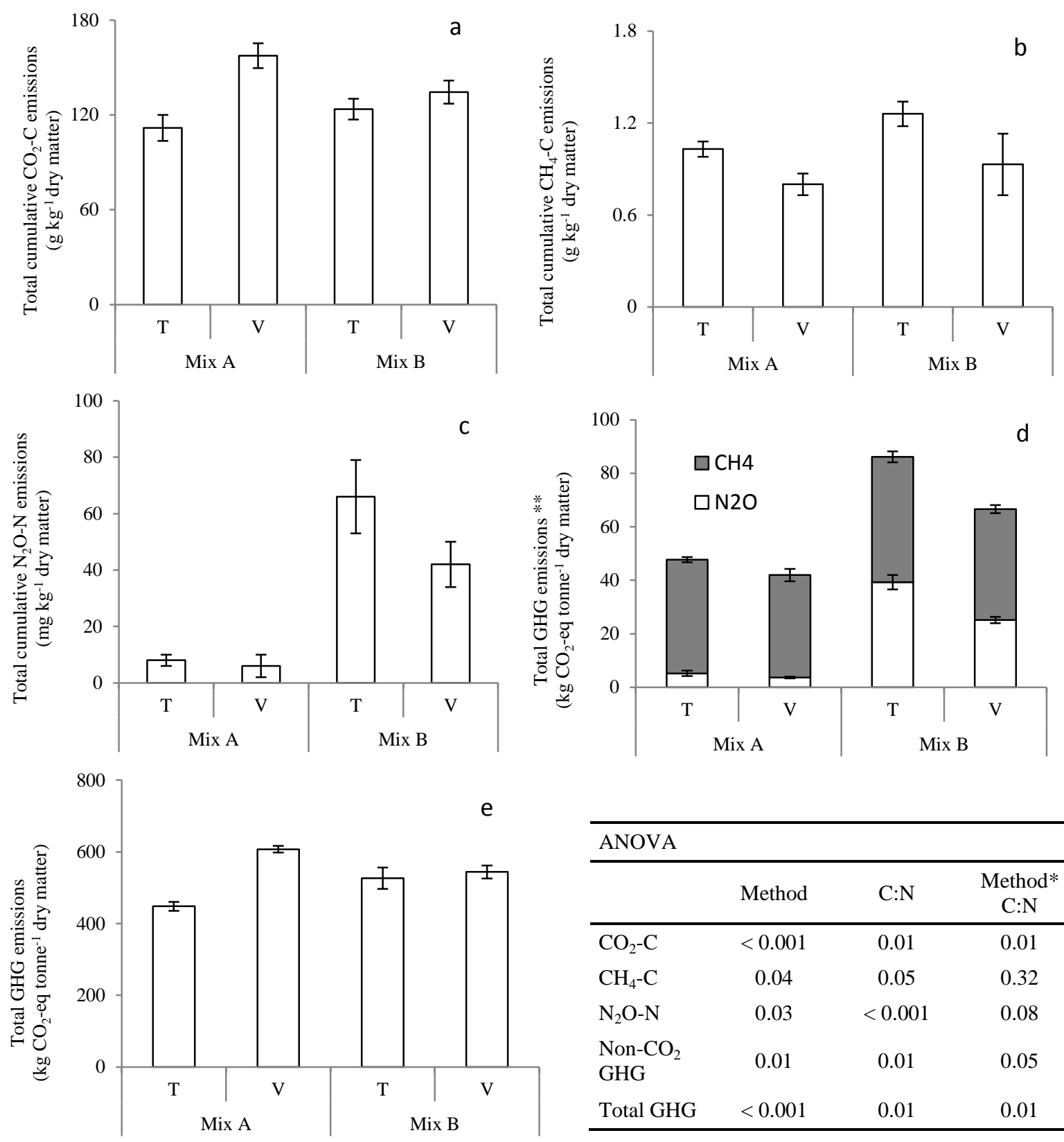

\begin{tabular}{lccc}
\hline ANOVA & & & \\
\hline & Method & $\mathrm{C}: \mathrm{N}$ & $\begin{array}{c}\text { Method* } \\
\text { C:N }\end{array}$ \\
\hline $\mathrm{CO}_{2}-\mathrm{C}$ & $<0.001$ & 0.01 & 0.01 \\
$\mathrm{CH}_{4}-\mathrm{C}$ & 0.04 & 0.05 & 0.32 \\
$\mathrm{~N}_{2} \mathrm{O}-\mathrm{N}$ & 0.03 & $<0.001$ & 0.08 \\
Non-CO & 0.01 & 0.01 & 0.05 \\
GHG & 0.01 & 0.01 & 0.01 \\
Total GHG & $<0.001$ & 01 & \\
\hline
\end{tabular}

Figure 3.2. Total cumulative GHG emissions after 45 days of composting: (a) $\mathrm{CO}_{2}-\mathrm{C}$, (b) $\mathrm{CH}_{4}-\mathrm{C}$, (c) $\mathrm{N}_{2} \mathrm{O}-\mathrm{N}$, (d) total non- $\mathrm{CO}_{2}$ GHG emissions, (e) total GHG emission including $\mathrm{CO}_{2} . \mathrm{T}=$ Thermophilic composting; $\mathrm{V}=$ vermicomposting; ${ }^{* *}$ indicates that $\mathrm{CO}_{2}$ emission is not included; bars indicate the standard error of the means $(n=3)$

\section{Nitrogen and carbon balance}

Total $\mathrm{N}$ loss varied between composting methods $(\mathrm{P}=0.02)$ and $\mathrm{C}: \mathrm{N}$ ratios $(\mathrm{P}=0.01)$. Vermicomposting reduced total $\mathrm{N}$ loss by $10 \%$ from the high C:N substrate and by $20 \%$ from the low $\mathrm{C}: \mathrm{N}$ substrate (Table 3.2). Total $\mathrm{C}$ varied between composting methods $(\mathrm{P}=$ 0.001) and substrate $\mathrm{C}: \mathrm{N}(\mathrm{P}=0.001)$ (Table 3.2). Vermicomposting increased total $\mathrm{C}$ loss irrespective of the substrate C:N (Table 3.2). C loss varied between $44 \%$ and $46 \%$ of initial 


\section{Chapter 3}

C content after vermicomposting and $40-43 \%$ of initial C content after thermophilic composting.

Table 3.2. Carbon and nitrogen mass balances after 45 days of thermophilic composting and vermicomposting (Mean \pm SEM; $\mathrm{n}=3$ )

\begin{tabular}{|c|c|c|c|c|c|c|c|}
\hline \multirow{3}{*}{ Treatments } & \multicolumn{4}{|l|}{ C balance } & \multicolumn{3}{|l|}{$\mathrm{N}$ balance } \\
\hline & $\begin{array}{c}\text { Total C } \\
\text { retained }\end{array}$ & $\begin{array}{c}\mathrm{C} \text { loss } \\
\left(\mathrm{CO}_{2}-\mathrm{C}\right)\end{array}$ & $\begin{array}{c}\text { C-loss } \\
\left(\mathrm{CH}_{4}-\mathrm{C}\right)\end{array}$ & $\begin{array}{c}\text { Carbon } \\
\text { unaccounted }\end{array}$ & $\begin{array}{l}\text { Total } \mathrm{N} \\
\text { retained }\end{array}$ & $\begin{array}{c}\mathrm{N} \text { loss } \\
\left(\mathrm{N}_{2} \mathrm{O}-\mathrm{N}\right)\end{array}$ & $\begin{array}{c}\mathrm{N} \text { losses as } \\
\left(\mathrm{NH}_{3}-\mathrm{N}_{2} \mathrm{~N}_{2}\right. \\
\left.\mathrm{NO}_{\mathrm{x}}\right)\end{array}$ \\
\hline & \multicolumn{4}{|c|}{ 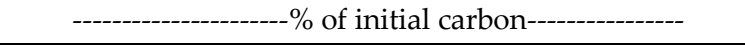 } & \multicolumn{3}{|c|}{------\% of initial nitrogen------ } \\
\hline T_mix A & $60.4 \pm 0.8$ & $25.0 \pm 1.2$ & $0.19 \pm 0.02$ & $14.4 \pm 0.7$ & $77.0 \pm 1.9$ & 0.09 & $22.8 \pm 2.2$ \\
\hline T_mix B & $57.0 \pm 1.2$ & $30.3 \pm 1.7$ & $0.22 \pm 0.01$ & $12.5 \pm 2.0$ & $69.6 \pm 0.7$ & 0.41 & $29.8 \pm 1.3$ \\
\hline V_mix A & $56.5 \pm 0.6$ & $33.6 \pm 0.5$ & $0.14 \pm 0.02$ & $9.7 \pm 1.4$ & $79.4 \pm 1.1$ & 0.04 & $21.3 \pm 0.9$ \\
\hline V_mix B & $54.5 \pm 1.0$ & $31.3 \pm 0.5$ & $0.20 \pm 0.01$ & $14.0 \pm 0.6$ & $76.3 \pm 1.9$ & 0.30 & $22.2 \pm 1.4$ \\
\hline \multicolumn{8}{|l|}{ ANOVA } \\
\hline Method & 0.01 & $<0.001$ & 0.03 & 0.24 & 0.02 & 0.03 & 0.02 \\
\hline Mix & 0.01 & 0.01 & 0.02 & 0.81 & 0.01 & $<0.001$ & 0.06 \\
\hline Method ${ }^{*} \operatorname{mix}$ & 0.30 & 0.01 & 0.28 & 0.10 & 0.14 & 0.10 & 0.24 \\
\hline
\end{tabular}

\section{Effect of earthworm density on GHG emissions (Experiment II)}

Analysis of variance showed that higher earthworm density increased $\mathrm{CO}_{2}$ emissions in all substrates $(\mathrm{P}=0.04)$. Higher earthworm density decreased $\mathrm{CH}_{4}$ emissions by $12-36 \%$ $(P=0.011)$ and had a marginal effect on $\mathrm{N}_{2} \mathrm{O}$ emissions $(\mathrm{P}=0.05)$. The addition of more straw reduced the earthworm density effect on $\mathrm{N}_{2} \mathrm{O}$ emissions (Fig. 3.3). Both $\mathrm{CH}_{4}$ and $\mathrm{N}_{2} \mathrm{O}$ emissions varied significantly between substrates $(\mathrm{P}<0.001)$. Vermicomposting of vegetable waste (i.e. mixtures $A$ and $B$ ) produced the highest amounts of $\mathrm{CO}_{2}$ and $\mathrm{CH}_{4}$ compared with the substrates also containing pre-decomposed cattle manure (i.e. mixtures $\mathrm{C}$ and D) (Fig. 3.3). The highest $\mathrm{N}_{2} \mathrm{O}$ emissions were found in substrates containing pre-decomposed manure compared with vegetable waste. Higher earthworm density did not affect the total GHG budget if $\mathrm{CO}_{2}$ was excluded from total GHG emissions (Fig. 3.3d). However, higher earthworm density marginally influenced total GHG emissions $(\mathrm{P}=0.08)$ when $\mathrm{CO}_{2}$ was included (Fig. 3.3e). 

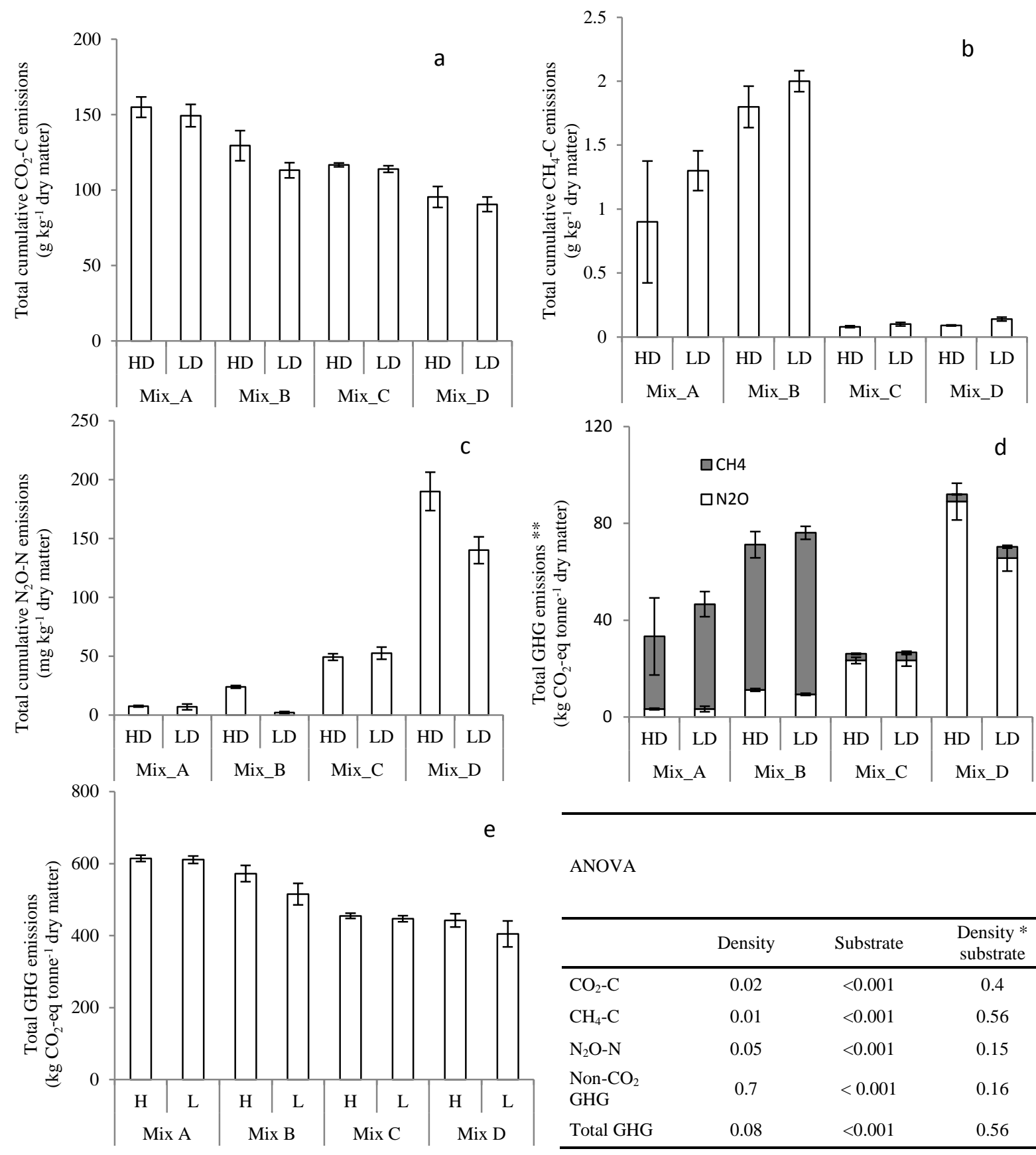

ANOVA

\begin{tabular}{lccc}
\hline & Density & Substrate & $\begin{array}{c}\text { Density * } \\
\text { substrate }\end{array}$ \\
\hline $\mathrm{CO}_{2}-\mathrm{C}$ & 0.02 & $<0.001$ & 0.4 \\
$\mathrm{CH}_{4}-\mathrm{C}$ & 0.01 & $<0.001$ & 0.56 \\
$\mathrm{~N}_{2} \mathrm{O}-\mathrm{N}$ & 0.05 & $<0.001$ & 0.15 \\
$\mathrm{Non-}-\mathrm{CO}_{2}$ & 0.7 & $<0.001$ & 0.16 \\
$\mathrm{GHG}$ & & $<0.001$ & 0.56 \\
Total GHG & 0.08 & &
\end{tabular}

Figure 3.3. Total cumulative GHG emissions from different earthworm densities and substrates: (a) $\mathrm{CO}_{2}-\mathrm{C}$ emissions, (b) $\mathrm{CH}_{4}-\mathrm{C}$ emissions, (c) $\mathrm{N}_{2} \mathrm{O}-\mathrm{N}$ emissions, (d) total non- $\mathrm{CO}_{2}$ GHG emissions, (e) total GHG emissions including $\mathrm{CO}_{2}$. $\mathrm{HD}=$ earthworm density at $3 \mathrm{~kg} \mathrm{~m}^{-2} ; \mathrm{LD}=$ earthworm density at 1 $\mathrm{kg} \mathrm{m}^{-2}$; Mix A = 5:1 (waste : straw ratio); Mix B = 10:1 (waste : straw ratio); $\mathrm{DM}=$ dry matter; $\mathrm{Mix} \mathrm{C}=$ 4:1:1/4 (waste : manure : straw ratio); Mix $\mathrm{D}=3: 1: 0$ (waste : manure $:$ straw mixture); ${ }^{* *}$ indicates that $\mathrm{CO}_{2}$ is not included; bars indicate the standard error of the means $(\mathrm{n}=3)$ 


\section{Effect of C quality and moisture on GHG emissions (Experiment III)}

The addition of glucose increased the total cumulative $\mathrm{CO}_{2}$ and $\mathrm{CH}_{4}$ emissions from vermicompost $\left(\mathrm{P}<0.001\right.$ and $\mathrm{P}<0.001$ respectively) (Fig. 3.4). The glucose effect on $\mathrm{N}_{2} \mathrm{O}$ emissions was non-significant $(\mathrm{P}=0.13)$. The higher moisture content increased total cumulative $\mathrm{CH}_{4}$ emissions $(\mathrm{P}<0.001)$ and $\mathrm{N}_{2} \mathrm{O}$ emissions $(\mathrm{P}=0.01)$. The effect of moisture on $\mathrm{CH}_{4}$ and $\mathrm{N}_{2} \mathrm{O}$, however, was only pronounced in the treatments without earthworms (Fig. 3.4). Earthworm treatments decreased $\mathrm{CH}_{4}$ emissions by $9-53 \%(\mathrm{P}<$ 0.001 ) and $\mathrm{N}_{2} \mathrm{O}$ emissions by $16-59 \%$ ( $\left.\mathrm{P}<0.001\right)$ compared with non-earthworm treatments. Earthworms decreased $\mathrm{N}_{2} \mathrm{O}$ emissions by $40 \%$ with higher moisture and by $23 \%$ with lower moisture. Earthworms also decreased $\mathrm{CH}_{4}$ emissions by $32 \%$ and $16 \%$ with higher and lower moisture respectively.

\section{Change in chemical properties}

The composting method and $\mathrm{C}: \mathrm{N}$ ratio affected $\mathrm{C}$ and $\mathrm{N}$ concentration in the end product $(\mathrm{P}<0.01$ and $\mathrm{P}<0.001$ respectively). The $\mathrm{C}$ concentration was higher in thermophilic composting than in vermicomposting (Table 3.3). Vermicomposting resulted in a higher total nitrogen concentration than thermophilic composting for all substrates. Total $\mathrm{N}$ concentration increased by $26-33 \%$ after vermicomposting, but only by $18-20 \%$ after thermophilic composting. The composting method did not affect $\mathrm{NH}_{4}{ }^{+}$ concentration $(\mathrm{P}=0.23)$, however $\mathrm{NH}_{4}{ }^{+}$concentration varied significantly between substrates $(\mathrm{P}<0.001)$ (Table 3.3). $\mathrm{NO}_{3}{ }^{-}$concentration varied between the composting methods $(\mathrm{P}=0.03)$ and $\mathrm{C}: \mathrm{N}$ ratio $(\mathrm{P}<0.001)$. Vermicomposting increased $\mathrm{NO}_{3}{ }^{-}$ concentration by $14 \%$ and $33 \%$ with the high and low C:N ratio respectively compared with thermophilic composting (Table 3.3). During Experiment III, vermicomposting also increased $\mathrm{NO}_{3}$ - concentration by $164-401 \%$ ( $\left.\mathrm{P}<0.0001\right)$ compared with non-earthworm treatments (Supplementary Fig. 3.1). Earthworm density, however, did not affect $\mathrm{NH}_{4}{ }^{+}$ and $\mathrm{NO}_{3}$ - concentrations.

\section{Earthworm biomass}

The earthworm biomass increased in all vermicomposting experiments (Fig. 3.5). The relative change in earthworm biomass was significantly affected by substrate $\mathrm{C}: \mathrm{N}$ ratio $(\mathrm{P}<0.001)$, but not by the initial earthworm density $(\mathrm{P}=0.14)$. Mixtures containing decomposed cattle manure (i.e. mixtures $\mathrm{C}$ and $\mathrm{D}$ ) increased the earthworm biomass by more than $80 \%$, while the mixtures of vegetable waste and straw (i.e. mixtures A and B) increased the earthworm biomass by just $40 \%$. Higher moisture content increased earthworm biomass by 50-57\% ( $\mathrm{P}<0.001)$ compared with the lower moisture content. The addition of glucose marginally increased the earthworm biomass (Fig. 3.5). 

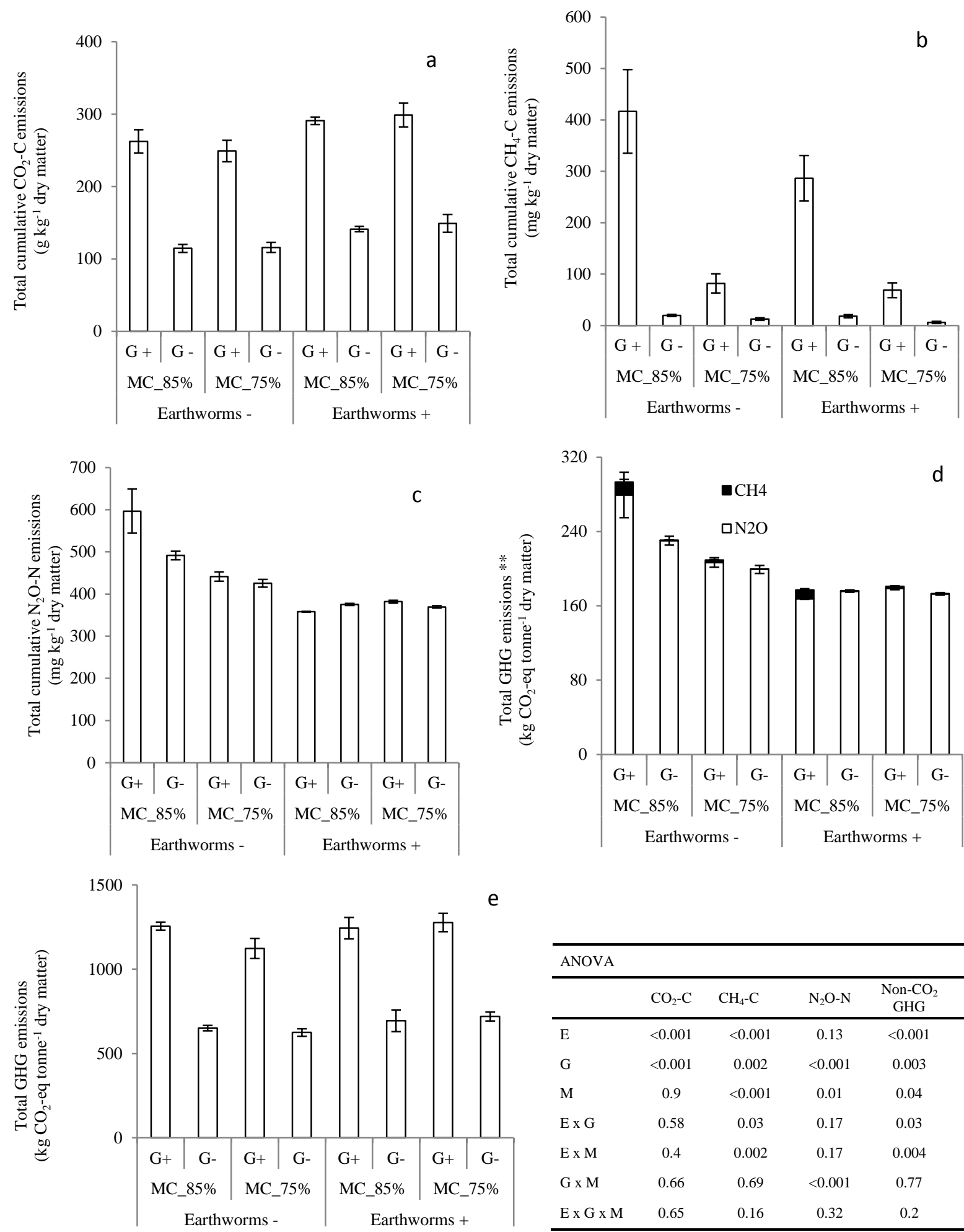

\begin{tabular}{lccccc}
\hline ANOVA & & & & & \\
\hline & $\mathrm{CO}_{2}-\mathrm{C}$ & $\mathrm{CH}_{4}-\mathrm{C}$ & $\mathrm{N}_{2} \mathrm{O}-\mathrm{N}$ & $\begin{array}{c}\mathrm{Non}^{-\mathrm{CO}_{2}} \\
\mathrm{GHG}\end{array}$ & $\begin{array}{c}\text { Total } \\
\mathrm{GHG}\end{array}$ \\
\hline $\mathrm{E}$ & $<0.001$ & $<0.001$ & 0.13 & $<0.001$ & $<0.001$ \\
$\mathrm{G}$ & $<0.001$ & 0.002 & $<0.001$ & 0.003 & $<0.001$ \\
$\mathrm{M}$ & 0.9 & $<0.001$ & 0.01 & 0.04 & 0.55 \\
Ex G & 0.58 & 0.03 & 0.17 & 0.03 & 0.98 \\
Ex M & 0.4 & 0.002 & 0.17 & 0.004 & 0.91 \\
G x M & 0.66 & 0.69 & $<0.001$ & 0.77 & 0.62 \\
Ex G x M & 0.65 & 0.16 & 0.32 & 0.2 & 0.88 \\
\hline & & & & &
\end{tabular}

Figure 3.4. Total cumulative GHG emissions from different qualities of substrate: (a) $\mathrm{CO}_{2}-\mathrm{C}$ emissions, (b) $\mathrm{CH}_{4}-\mathrm{C}$ emissions, (c) $\mathrm{N}_{2} \mathrm{O}-\mathrm{N}$ emissions, (d) total non- $\mathrm{CO}_{2}$ GHG emissions, (e) total GHG emissions including $\mathrm{CO}_{2}$. $\mathrm{G}^{+}=$glucose added; $\mathrm{G}-=$ glucose not added; $\mathrm{MC} \_85 \%=$ moisture content of $85 \%$; MC_75\% = moisture content of 75\%; Earthworms - = without earthworms; Earthworms $+=$ earthworms added; ${ }^{* *}$ indicates that $\mathrm{CO}_{2}$ is not included; bars indicate the standard error of the means $(\mathrm{n}=3)$ 


\section{Chapter 3}

Table 3.3. Chemical properties of the end products after 45 days of thermophilic composting and vermicomposting

\begin{tabular}{|c|c|c|c|c|c|c|}
\hline & Total C & Total N & $\mathrm{C}: \mathrm{N}$ & $\mathrm{NH}_{4}^{+}$ & $\mathrm{NO}_{3}^{-}$ & $\mathrm{pH}$ \\
\hline & \multicolumn{2}{|c|}{.......... $\mathrm{g} \mathrm{kg}^{-1} \mathrm{DM} \ldots \ldots \ldots . . .}$. & \multicolumn{4}{|c|}{............mg kg ${ }^{-1} \mathrm{DM} \ldots \ldots . . . . .}$. \\
\hline T_mix A & 412.3 & 17.3 & 23.8 & 558.7 & 327 & 8.0 \\
\hline T_Mix B & 383.8 & 21.1 & 18.2 & 1398.7 & 440 & 7.7 \\
\hline V_mix A & 399.2 & 18.3 & 21.9 & 884.5 & 374 & 7.6 \\
\hline V_mix B & 376.7 & 23.1 & 16.3 & 1450.9 & 583 & 6.8 \\
\hline \multicolumn{7}{|l|}{ ANOVA } \\
\hline Method & 0.01 & $<0.001$ & $<0.001$ & 0.03 & 0.23 & $<0.001$ \\
\hline Mixture & $<0.001$ & $<0.001$ & $<0.001$ & 0.002 & 0.001 & 0.004 \\
\hline Method*mixture & 0.39 & 0.07 & 0.90 & 0.22 & 0.38 & 0.06 \\
\hline
\end{tabular}

$\mathrm{T}$ = thermophilic composting; $\mathrm{V}=$ vermicomposting; $\operatorname{mix} \mathrm{A}=5: 1$ (waste : straw ratio); mix $\mathrm{B}=10: 1$ (waste : straw ratio); $\mathrm{N}$ = nitrogen; $\mathrm{C}=$ carbon; $\mathrm{DM}=$ dry matter
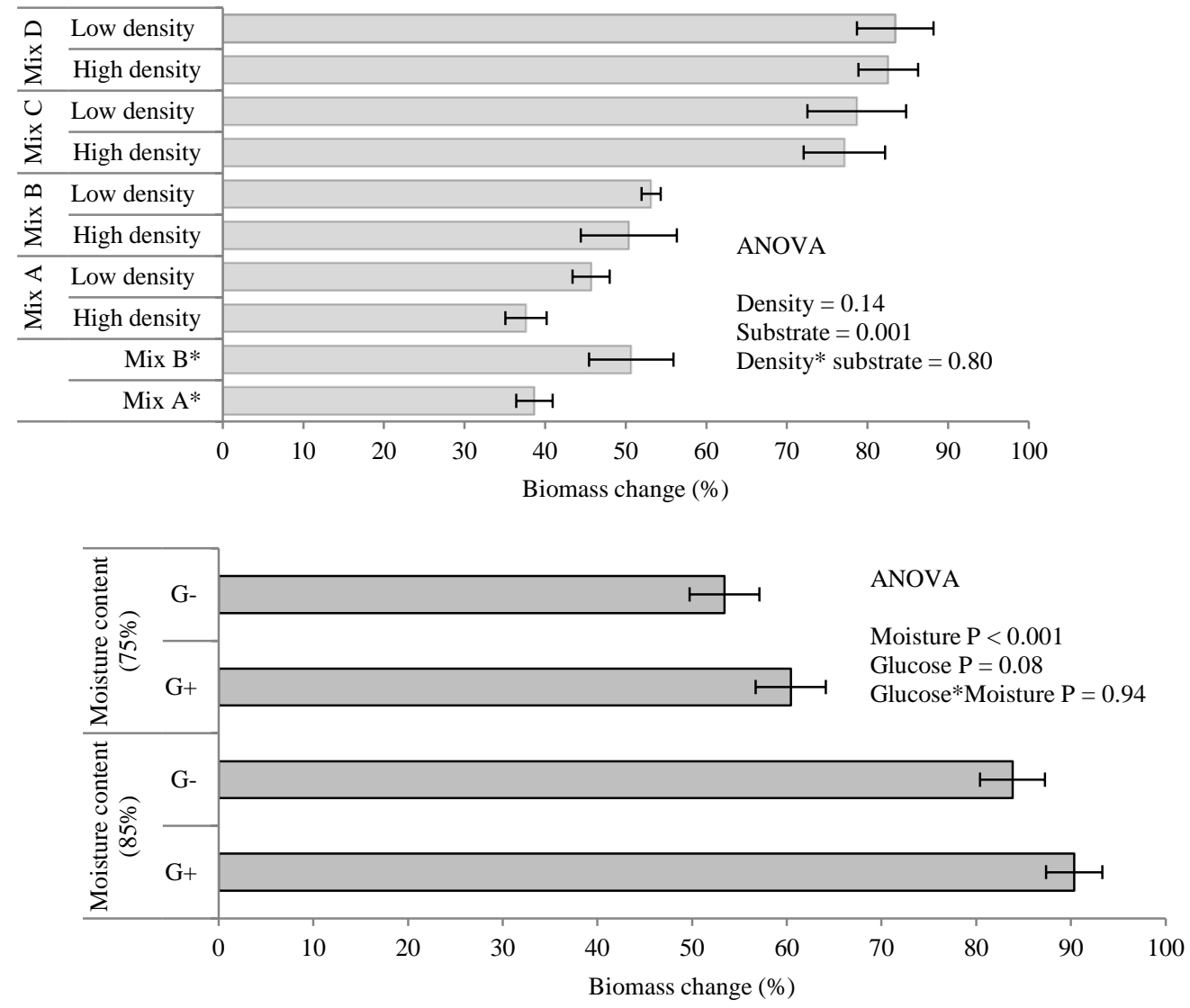

Figure 3.5. Change in earthworm biomass after 45 days of vermicomposting: high density $=3 \mathrm{~kg} \mathrm{~m}^{-2}$; low density = at $1 \mathrm{~kg} \mathrm{~m}^{-2}$; Mix A = 5:1 (waste : straw ratio); Mix B = 10:1 (waste : straw ratio); Mix C = 4:1:1/4 (waste : manure : straw ratio); mix $\mathrm{D}=3: 1: 0$ (waste : manure : straw mixture); $\mathrm{G}+=$ glucose added; G- = glucose not added; * indicates biomass change during experiment $\mathrm{I}$; bars indicate the standard error of the means $(n=3)$ 


\section{Discussion}

\section{Earthworms and GHG emissions from vermicomposting}

\section{Methane and nitrous oxide}

The hypothesis that vermicomposting decreases $\mathrm{CH}_{4}$ and $\mathrm{N}_{2} \mathrm{O}$ emissions irrespective of the substrate quality ( $\mathrm{C}: \mathrm{N}$ ratio and presence of a labile $\mathrm{C}$ pool) (Figs. 3.2 and 3.4) was confirmed. In agreement with these findings, earthworms have been found to decrease $\mathrm{CH}_{4}$ emissions by $>40 \%$ during vermicomposting of manure (Wang et al., 2014) and $\mathrm{N}_{2} \mathrm{O}$ emission by $>80 \%$ during vermifiltration of pig slurry (Luth et al., 2011). Vermifiltration is a wastewater treatment using epigeic earthworms, which is a different system from that used in the present study. Wang et al. (2014) also observed a 6-27\% decrease in $\mathrm{N}_{2} \mathrm{O}$ emission during vermicomposting of manure. The present study, however, is the first to evaluate the effectiveness of vermicomposting to reduce GHG emissions using a wide range of variables (C:N ratio, carbon quality, moisture and earthworm density). Continuous turning of the substrates by earthworms and subsequent higher air circulation explained the decrease in $\mathrm{CH}_{4}$ and $\mathrm{N}_{2} \mathrm{O}$ emissions after vermicomposting, which is also supported by the lower $\mathrm{CH}_{4}$ emissions with the higher earthworm density, as hypothesised. The higher temperature $\left(45-56{ }^{\circ} \mathrm{C}\right)$ in the thermophilic phase compared with vermicomposting $\left(<27^{\circ} \mathrm{C}\right.$ ) (Supplementary Fig. 3.2) may also contribute to the differences in $\mathrm{CH}_{4}$ emissions between the composting methods. High microbial activities during the active phase of composting increase temperature and oxygen consumption, and subsequently increase $\mathrm{CH}_{4}$ production (Chowdhury et al., 2014; $\mathrm{Vu}$ et al., 2015). Chowdhury et al. (2014) found a positive correlation between composting temperature and $\mathrm{CH}_{4}$ emissions. $\mathrm{N}_{2} \mathrm{O}$ emission occurs during both nitrification and denitrification processes, implying that excess aeration increases nitrification and consequently results in high $\mathrm{N}_{2} \mathrm{O}$ production (Jiang et al., 2011). Surplus air circulation could therefore explain the slight increase in $\mathrm{N}_{2} \mathrm{O}$ emission at higher earthworm density. The effect of earthworm density on $\mathrm{N}_{2} \mathrm{O}$ was less pronounced in straw-amended substrates, suggesting that initial nitrogen content, aeration and other composting parameters might influence the effect of earthworm abundance on $\mathrm{N}_{2} \mathrm{O}$ emissions.

Increasing the $\mathrm{C}: \mathrm{N}$ ratio (addition of straw) reduced $\mathrm{CH}_{4}$ and $\mathrm{N}_{2} \mathrm{O}$ emissions from both composting methods, as hypothesised (Figs. 3.2 and 3.3). The addition of straw or bulking agents improves porosity and regulates moisture in a compost pile and thereby reduces $\mathrm{CH}_{4}$ and $\mathrm{N}_{2} \mathrm{O}$ emissions (Santos et al., 2016; $\mathrm{Vu}$ et al., 2014). The addition of glucose also increased $\mathrm{CH}_{4}$ emissions as hypothesised. Higher $\mathrm{CH}_{4}$ emissions from the addition of glucose to substrates (Fig. 3.4) implies that labile $\mathrm{C}$ pools could easily be used by methanogenic microorganisms to produce $\mathrm{CH}_{4}$ (Garcia-Marco et al., 2014). The 
addition of labile $\mathrm{C}$ sources (glucose) also increased microbial oxygen demand and thereby caused anaerobic microsites for $\mathrm{CH}_{4}$ and $\mathrm{N}_{2} \mathrm{O}$ production. Higher $\mathrm{CH}_{4}$ emissions from vegetable waste than from pre-decomposed manure (Fig. 3.3) confirmed the hypothesis that a high proportion of easily decomposable materials increase $\mathrm{CH}_{4}$ production. The effect of glucose addition on $\mathrm{N}_{2} \mathrm{O}$ emissions, however, was inconsistent with this study's hypothesis. $\mathrm{N}_{2} \mathrm{O}$ emissions were mainly affected by $\mathrm{NO}_{3}$ - concentration. Higher $\mathrm{N}_{2} \mathrm{O}$ emissions from pre-decomposed manure than from vegetable mixtures (Fig. 3.3) could be explained by the higher concentration of $\mathrm{NO}_{3}^{-}$(Table 3.1). A high moisture content increases anaerobic patches in compost piles and thereby increases $\mathrm{CH}_{4}$ and $\mathrm{N}_{2} \mathrm{O}$ emissions. However, this study showed that earthworms reduced the moisture effect on $\mathrm{CH}_{4}$ and $\mathrm{N}_{2} \mathrm{O}$, as hypothesised (Fig. 3.4), because the earthworms mixed the substrates continuously and thereby counterbalanced the moisture effect. The results are consistent with the $34 \%$ decrease in $\mathrm{N}_{2} \mathrm{O}$ due to earthworms in the soil with higher moisture (i.e. 97\% water-filled pore space) (Chen et al., 2014).

\section{Carbon dioxide}

Total cumulative $\mathrm{CO}_{2}$ emissions were higher from vermicomposting than from thermophilic composting, as hypothesised. Experiment III also confirmed this hypothesis since vermicomposting increased total cumulative $\mathrm{CO}_{2}$ emissions by $11-26 \%$ relative to non-earthworm treatments. Higher total cumulative $\mathrm{CO}_{2}$ emissions indicate a higher biodegradation rate and stabilisation (Chan et al., 2011). The results from the present study therefore suggest that vermicomposting enhances decomposition of waste materials compared with thermophilic compost. Similarly, the $\mathrm{CO}_{2}$ flux after 45 days was between 0.15 and $0.5 \mathrm{~g} \mathrm{CO}_{2}-\mathrm{C} \mathrm{kg}^{-1}$ dry matter day ${ }^{-1}$ in vermicompost and $0.98-1.3 \mathrm{~g} \mathrm{CO}_{2-}$ $\mathrm{C} \mathrm{kg}^{-1}$ dry matter day ${ }^{-1}$ in thermophilic compost, implying that vermicompost was at a more advanced stage of decomposition than conventional compost. It is possible to argue that earthworm respiration could contribute to higher $\mathrm{CO}_{2}$ emissions from vermicomposting. However, this argument cannot explain the higher $\mathrm{CO}_{2}$ emissions in the earthworm treatments because the difference observed was greater than the earthworm respiration. The effect of earthworms on $\mathrm{CO}_{2}$ emissions was less clear in the low C:N and substrates with glucose (Figs. 3.2 and 3.4) because a higher proportion of easily decomposable materials (i.e. low C:N and glucose-added substrates) resulted in much higher decomposition (Chowdhury et al., 2014), which exceeded the earthworms' effect. The higher $\mathrm{CO}_{2}$ emissions at higher earthworm density implied that decomposition of vermicompost could be accelerated by increasing the earthworm population from the optimal earthworm density $\left(1.6 \mathrm{~kg}\right.$ earthworms $\left.\mathrm{m}^{-2}\right)$ recommended by Ndegwa et al. (2000). 


\section{Total GHG emissions}

This study used two different scenarios to assess the GHG budget from the two composting methods. The first scenario excluded $\mathrm{CO}_{2}$ emissions from the total GHG budget. Under this scenario, vermicomposting had a lower total GHG budget than thermophilic composting, as hypothesised. The lower GHG budget from vermicomposting was explained by the lower $\mathrm{N}_{2} \mathrm{O}$ and $\mathrm{CH}_{4}$ production (Figs. 3.2 and 3.4). The second scenario included $\mathrm{CO}_{2}$ emissions in the GHG budget, and under this scenario total GHG emissions were higher from vermicomposting than from thermophilic composting. This variation was expected because $\mathrm{CO}_{2}$ emissions were higher during vermicomposting, and $\mathrm{CO}_{2}$ contributed over $75 \%$ of the total GHG budget in all treatments. Similarly, Anderson et al. (2010) and Chan et al. (2011) reported an 80\% contribution of $\mathrm{CO}_{2}$ to total GHG emissions during household waste composting. Higher $\mathrm{CO}_{2}$ emissions indicate a greater stability of the remaining material (i.e. a higher decomposition). It is therefore important to exclude $\mathrm{CO}_{2}$ from the total GHG budget of composting experiments (Schott et al., 2016; $\mathrm{Vu}$ et al., 2015), including as biogenic $\mathrm{CO}_{2}$ from short-term pools, as plant litter is usually excluded from greenhouse gas balances (IPCC, 2013). Substrate quality determined the relative contribution of $\mathrm{N}_{2} \mathrm{O}$ and $\mathrm{CH}_{4}$ to the total GHG budget (Figs. 3.2, 3.3 and 3.4). The contribution of $\mathrm{CH}_{4}$ was higher than $\mathrm{N}_{2} \mathrm{O}$ in vegetable waste composting due to the high proportion of easily degradable $\mathrm{C}$, which favours $\mathrm{CH}_{4}$ production. The $\mathrm{N}_{2} \mathrm{O}$ contribution was higher from cattle manure, which was explained by the high mineral $\mathrm{N}$ concentration in cattle manure.

\section{Nitrogen and carbon balance}

Total $\mathrm{N}$ loss was lower after vermicomposting than thermophilic composting, as hypothesised. The $\mathrm{N}$ loss as $\mathrm{N}_{2} \mathrm{O}$ was small (less than $1 \%$ of the total $\mathrm{N}$ loss) (Table 3.3), therefore other gaseous losses such as $\mathrm{NH}_{3}, \mathrm{NO}_{x}$ and $\mathrm{N}_{2}$ explain the variation in $\mathrm{N}$ loss between the two composting methods. No $\mathrm{N}$ loss via leaching was observed during the experimental period. $\mathrm{NH}_{3}$ is the major $\mathrm{N}$ loss from composting (Jiang et al., 2011), and temperatures above $45{ }^{\circ} \mathrm{C}$ increase $\mathrm{NH}_{3}$ volatilisation (Chowdhury et al., 2014). Hence, higher temperatures $\left(45-56{ }^{\circ} \mathrm{C}\right)$ during the active phase (Supplementary Fig. 3.1) explain the higher $\mathrm{N}$ loss during thermophilic composting. The active phase was short (i.e. three days), typical of small-scale composting systems (Bustamante et al., 2013; Lieo et al., 2013), however this temperature is sufficient to produce a significant $\mathrm{NH}_{3}$ loss (Chowdhury et al., 2014; Vu et al., 2015). Total N loss was lower compared with previous studies on manure composting (Chowdhury et al., 2014; Vu et al., 2015) and this difference can be explained by the lower $\mathrm{N}$ concentration in the substrates (Table 3.1) relative to manure (25 - $38.6 \mathrm{~g} \mathrm{~kg}^{-1}$ dry matter) (Chowdhury et al., 2014; Vu et al., 2015). The $\mathrm{NO}_{3}^{-}$concentration increased during composting and was higher after 
vermicomposting, implying higher $\mathrm{N}$ mineralisation, nitrification and lower $\mathrm{NH}_{3}$ loss in the vermicompost than in conventional compost. Moreover, the more rapid decrease in $\mathrm{NH}_{4}{ }^{+}$concentration after thermophilic composting suggested high $\mathrm{NH}_{3}$ loss.

Vermicomposting increased total C loss compared with thermophilic composting, irrespective of substrate quality (Table 3.3). $\mathrm{CO}_{2}$ loss accounted for over $65 \%$ of $\mathrm{C}$ loss (Table 3.3), therefore higher $C$ loss after vermicomposting was explained by (i) earthworms decomposing C (Lubbers et al., 2013) (ii) earthworms mixing the substrate, thereby increasing the accessibility of the materials for decomposers, and (iii) earthworm casts increasing decomposition (Sierra et al., 2013). The unaccounted C was between 9$14 \%$, which is comparable with several studies (Chowdhury et al., 2014; Vu et al., 2015). The unaccounted $\mathrm{C}$ indicates $\mathrm{C}$ that was not measured between sampling dates $(\mathrm{Vu}$ et al., 2015) and/or C loss via volatile compounds (Chowdhury et al., 2014). The sampling frequency might be inadequate for capturing all $\mathrm{CO}_{2}$ emissions, particularly from vermicomposting where intensive decomposition occurs. The increase in earthworm biomass (Fig. 3.5) also explains some of the unaccounted carbon during vermicomposting.

\section{Implications for small-scale farmers}

Gaseous N losses and GHG emissions have been reported from thermophilic composting (Chowdhury et al., 2014), and these emissions reduce the agronomic value of compost and contribute to climate change and nuisance odour. The addition of bulking agents such as crop residues (Santos et al., 2016; Vu et al., 2015), the control of aeration rate (Chowdhury et al., 2014) and the control of pH (Awasthi et al., 2016) have been identified as means of reducing $\mathrm{N}$ losses and GHG emissions from composting. However, it is difficult to apply these practices in many developing countries, for instance because of the competing uses of crop residues, mainly for animal feed and fuel in smallholder farming systems (Nigussie et al., 2015), and the need for labour to turn compost piles, determining factors in the adoption of composting in developing countries (Nigussie et al., 2015). Technologies such as forced aeration are expensive and difficult to scale up to field conditions. It is therefore suggested that vermicomposting is a more practical and less expensive method than the existing solutions to reduce GHG emissions, enhance the fertilising value of compost and close the nutrient loop in smallholder farming systems. Temperatures above $45{ }^{\circ} \mathrm{C}$ are essential in order to remove pathogens from compost (Velasco-Velasco et al., 2011). However, literature shows the effectiveness of vermicomposting at eradicating pathogens (Edwards et al., 2011; Rodríguez-Canché et al., 2010). Pre-composting prior to vermicomposting could be the solution to remove pathogens and weed seeds from vermicomposting (Wang et al., 2014), however N loss and GHG emissions during pre-composting need further investigation because higher $\mathrm{N}$ 
losses and GHG emissions might occur during the pre-composting stage (VelascoVelasco et al., 2011).

The experiments in this study were designed to correspond to the activity of small-scale farmers in developing countries; therefore care should be taken when extrapolating the results to large-scale enterprises. For example, temperatures may reach values above $60^{\circ} \mathrm{C}$ (Tortosa et al., 2012) during large-scale thermophilic composting. Hence, N losses and GHG emissions could be greater in large-scale composting systems. The earthworm effect on GHG budget might be smaller in large-scale vermicomposting because a high input of fresh material might offset the effect of earthworms on aeration (Luth et al., 2011).

Studies have shown earthworm-induced $\mathrm{N}_{2} \mathrm{O}$ emissions from soils (Lubbers et al., 2013) because denitrifying bacteria in the earthworm gut contribute to measurable $\mathrm{N}_{2} \mathrm{O}$ fluxes. However, caution should be exercised when interpreting this fact because substrate quality, earthworm species and earthworm abundance used for vermicomposting are different from soil experiments. Vermicomposting uses nitrogenrich substrates, higher earthworm density $\left(>1 \mathrm{~kg} \mathrm{~m}^{-2}\right)$ and epigeic earthworms, consequently the earthworms' effect on aeration exceeds the earthworm gut effect (denitrification). In contrast, soil usually has $<3 \%$ organic carbon, low earthworm density $\left(<2.1 \mathrm{~g} \mathrm{~m}^{-2}\right)$ and anecic earthworms, consequently the earthworm gut effect on denitrification is greater.

\section{Conclusions}

This study showed that vermicomposting reduces total $\mathrm{N}$ loss, $\mathrm{CH}_{4}$ and $\mathrm{N}_{2} \mathrm{O}$ emissions compared with thermophilic composting methods, irrespective of the substrate quality (i.e. C:N ratio, moisture content and presence of a labile $\mathrm{C}$ pool). Higher earthworm abundance reduces $\mathrm{CH}_{4}$ emissions and accelerates the decomposition process. The addition of labile $\mathrm{C}$ sources increases $\mathrm{CO}_{2}$ and $\mathrm{CH}_{4}$ emissions during composting. Vermicomposting increases $\mathrm{CO}_{2}$ emissions, implying that vermicompost is a more advanced stage of decomposition than thermophilic compost. Numerous solutions have been identified for reducing $\mathrm{N}$ losses and non- $\mathrm{CO}_{2}$ GHG emissions from composting, however the existing technologies are harder to apply in developing countries because they are expensive and difficult to upscale to larger systems. Vermicomposting, on the other hand, is a low-cost method, making it feasible for many resource-poor farmers to produce high fertilising value compost. Further studies, however, are needed to understand the effect of earthworms on $\mathrm{N}$ losses and GHG emissions from composting using different parameters such as substrate quality, earthworm species and feeding frequency. 


\section{Acknowledgements}

This work has been conducted as part of a $\mathrm{PhD}$ thesis project supported by the Agricultural Transformation by Innovation (AgTraIn) Erasmus Mundus Joint Doctorate Programme, funded by the EACEA (Education, Audio-visual and Culture Executive Agency) of the European Commission. The authors would like to acknowledge the anonymous reviewers for their constructive comments on the earlier version of the manuscript. 


\section{Appendix}
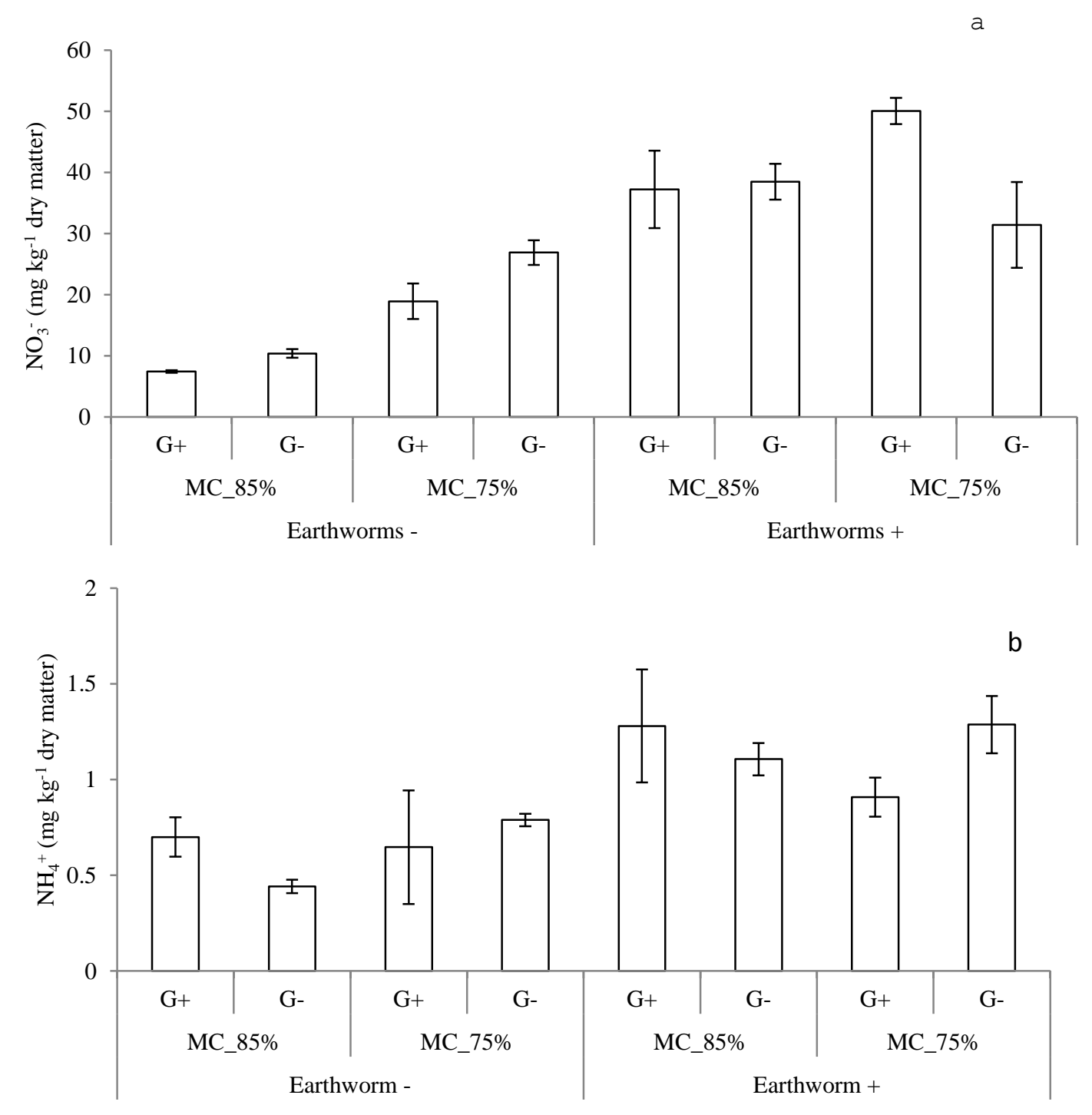

Supplementary Figure 3.1. Inorganic nitrogen concentration after 45 days of vermicomposting (Experiment III). (a) $\mathrm{NO}_{3}{ }^{-}$concentration, (b) $\mathrm{NH}_{4}{ }^{+}$concentration. G+ = glucose added; G- = glucose not added; MC_85\% = moisture content of $85 \%$; MC_75\% = moisture content of $75 \%$; Earthworms - = without earthworms; Earthworms $+=$ earthworms added; bars indicate the standard error of the means $(n=3)$ 

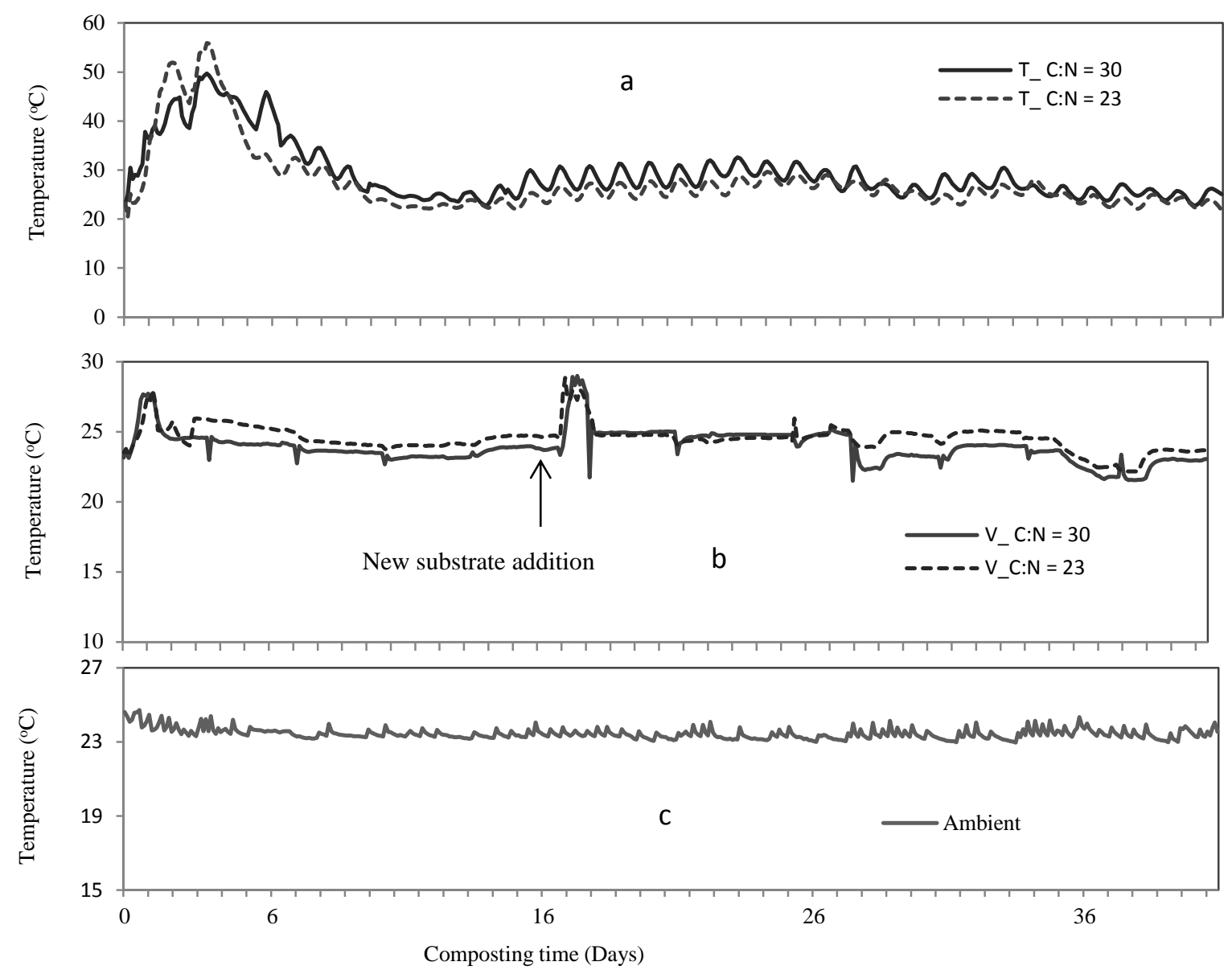

Supplementary Figure 3.2. Temperature evolution during composting (Experiment I). (a) thermophilic composting, (b) vermicomposting, and (c) ambient temperature (c). $\mathrm{T}=$ thermophilic composting; $\mathrm{V}=$ vermicomposting; arrow represents the addition of new substrate 


\section{CHAPTER 4}

\section{Delayed addition of nitrogen-rich substrates during composting of municipal waste: Effects on nitrogen loss, greenhouse gas emissions and compost stability}

This chapter is published at Chemosphere as:

Nigussie, A., Kuyper, T.W., Bruun, S., de Neergaard A. (2016). Delayed addition of nitrogen-rich substrates during composting of municipal waste: Effects on nitrogen loss, greenhouse gas emissions and compost stability. Chemosphere 166: 352-362 


\title{
Delayed addition of nitrogen-rich substrates during composting of municipal-waste: Effects on nitrogen loss, greenhouse gas emissions and compost stability
}

\begin{abstract}
Municipal waste is usually composted with an N-rich substrate, such as manure, to increase the $\mathrm{N}$ content of the product. This means that a significant amount of nitrogen can be lost during composting. The objectives of this study were (i) to investigate the effect of split addition of a nitrogen-rich substrate (poultry manure) on nitrogen losses and greenhouse gas emissions during composting and to link this effect to different bulking agents (coffee husks and sawdust), and (ii) to assess the effect of split addition of a nitrogen-rich substrate on compost stability and sanitisation. The results showed that split addition of the nitrogen-rich substrate reduced nitrogen losses by $9 \%$ when sawdust was used and $20 \%$ when coffee husks were used as the bulking agent. Depending on the bulking agent used, split addition increased cumulative $\mathrm{N}_{2} \mathrm{O}$ emissions by $400-600 \%$ compared to single addition. In contrast, single addition increased methane emissions by up to $50 \%$ compared to split addition of the substrate. Hence, the timing of the addition of the N-rich substrate had only a marginal effect on total non- $\mathrm{CO}_{2}$ greenhouse gas emissions. Split addition of the N-rich substrate resulted in compost that was just as stable and effective at completely eradicating weed seeds as single addition. These findings therefore show that split addition of a nitrogen-rich substrate could be an option for increasing the fertilising value of municipal waste compost without having a significant effect on total greenhouse gas emissions or compost stability.
\end{abstract}

Keywords: municipal wastes, poultry manure, bulking agent, split application 


\section{Introduction}

A large amount of municipal waste is generated globally due to rapid urban population growth (Scarlat et al., 2015). In many developing countries, over $80 \%$ of municipal waste ends up in landfills or incineration sites (Scarlat et al., 2015). Studies have shown that biodegradable materials constitute more than $50 \%$ of municipal waste in developing countries (Getahun et al., 2012a) and therefore composting has been suggested as a method to reduce the amount of municipal waste in landfill sites. More importantly, composting of municipal waste can be used to recycle nutrients from urban areas to agricultural land, thereby closing the rural-urban nutrient loop (Nigussie et al., 2015) and contributing to a circular economy.

Municipal-waste compost contains a high amount of organic matter, and incorporation in soil may therefore increase soil aggregate stability, reduce the draught force for soil tillage (Peltre et al., 2015), promote soil microbial activity and enhance soil chemical properties (Hargreaves et al., 2008). No adverse effects of the application of municipal waste compost on croplands have been reported (Poulsen et al., 2013).

However, municipal waste composts, particularly in many (sub)tropical countries, contain low levels of nitrogen $(\mathrm{N})$, commonly $<1 \%$ of dry matter (Getahun et al., 2012b). In addition, less than $10 \%$ of total $\mathrm{N}$ is mineralised from municipal waste compost in the first year after soil application (Zhang et al., 2006). This means that the compost will also contain relatively little mineralisable nitrogen, therefore relatively large amounts (40-50 $\mathrm{Mg} \mathrm{ha}^{-1}$ ) of compost have to be applied to satisfy plant requirements (Hargreaves et al., 2008). However, high input of municipal waste compost might result in losses of other nutrients and the accumulation of heavy metals in soils and plant tissues, thus impeding the ecological and environmental benefits of the compost. The optimisation of municipal waste composting should therefore place an emphasis on increasing the nitrogen concentration in the compost while reducing losses of other nutrients.

The composting of municipal waste and N-rich substrates such as poultry manure generally increases the $\mathrm{N}$ concentration in the compost (Lhadi et al., 2006; Rizzo et al., 2015). Poultry manure has a total $N$ content greater than $3 \%$ dry matter, but contains pathogens such as E. coli and Salmonella and weed seeds, implying that poultry manure should be treated (composted) prior to soil application. Composting of municipal waste with poultry manure is therefore a strategy for increasing the $\mathrm{N}$ concentration in compost and sanitising poultry manure.

Temperatures above $45{ }^{\circ} \mathrm{C}$ during composting, i.e. the thermophilic phase, are essential for compost sanitisation. High temperatures $\left(>45{ }^{\circ} \mathrm{C}\right)$ shift the $\mathrm{NH}_{4}{ }^{+}=\mathrm{NH}_{3}$ equilibrium towards ammonia (Pagans et al., 2006) and inhibit nitrification, both of which increase ammonia volatilisation. Poultry manure has a high NH4+ concentration, implying that composting of municipal waste with poultry manure may increase 
ammonia volatilisation, and thereby result in high $\mathrm{N}$ losses. High $\mathrm{N}$ loss has also been observed in experiments. For example Dias et al. (2010) and Rizzo et al. (2015) reported over $65 \% \mathrm{~N}$ loss during the thermophilic phase of poultry manure and crop residue composting. Minimising $\mathrm{N}$ losses is therefore essential for increasing the agronomic value of the final product and reducing environmental problems. Split addition of an Nrich substrate (i.e. poultry manure) has been suggested as a way of reducing $\mathrm{N}$ losses from composting (Bryndum, 2014; Dresbøll and Thorup-Kristensen, 2005). During split addition of an N-rich substrate, the first part is added at the beginning of composting in order to support the turnover of carbon (C). The remaining part is then added later (i.e. after the thermophilic phase) in order to increase the $\mathrm{N}$ concentration in the compost. It is hypothesised that split application of an $\mathrm{N}$-rich substrate reduces $\mathrm{N}$ losses via ammonia volatilisation.

C-rich materials (bulking agents), such as crop residues, are commonly added to compost mixtures to adjust the $\mathrm{C}: \mathrm{N}$ ratio so that immobilisation prevents losses and to adjust the moisture content and allow air movement through the compost pile (Yang et al., 2013). These C-rich materials influence the composting temperature (Santos et al., 2016) and $\mathrm{N}$ transformations such as mineralisation, immobilisation and volatilisation (Chowdhury et al., 2014). However, it is not known how the timing of the addition of an $\mathrm{N}$-rich substrate affects $\mathrm{N}$ losses under different C-rich materials.

In addition to high ammonia loss, composting produces a significant amount of greenhouse gases in the form of methane and nitrous oxide (Chowdhury et al., 2014). Inorganic N concentration (Nigussie et al., 2016a), C quality (Chowdhury et al., 2014) and temperature are among the key factors that influence greenhouse gas (GHG) emissions during composting. Methane $\left(\mathrm{CH}_{4}\right)$ is mainly produced in the thermophilic phase (Sánchez-Monedero et al., 2010) due to the presence of labile carbon compounds in conjunction with anoxic microsites. Nitrous oxide $\left(\mathrm{N}_{2} \mathrm{O}\right)$ is emitted after the thermophilic stage because nitrifying and denitrifying bacteria are mesophilic ( $\mathrm{Vu}$ et al., 2015). Hence, nitrification and denitrification, which are the major $\mathrm{N}_{2} \mathrm{O}$-producing processes, hardly occur during the thermophilic stage of composting. The timing of the addition of an $\mathrm{N}$ rich substrate might therefore influence GHG emissions from composting. For example, additions of an N-rich substrate after the thermophilic phase might increase $\mathrm{N}_{2} \mathrm{O}$ emissions by increasing the bioavailability of mineral $\mathrm{N}$ for nitrifying and denitrifying bacteria. On the other hand, the single addition of an N-rich substrate could trigger $\mathrm{CH}_{4}$ emissions due to the occurrence of anaerobic sites, high temperatures and bioavailable $\mathrm{C}$ and/or $\mathrm{N}$ for methanogenic bacteria. Studies also claim that high $\mathrm{NH}_{4}{ }^{+}$concentrations reduce methane oxidation due to the enzymatic similarity between methane and ammonium oxidation (Wei et al., 2016). However, no studies have been conducted to investigate the relationship between the timing of N-rich substrate addition and GHG emissions from composting. 
Compost should be free from pathogens and weed seeds, and must have a high level of stability prior to soil application. Compost is considered stable when the rate of organic matter decomposition is reduced to an insignificant level. Application of unstable compost leads to oxygen depletion in the root zone, and may impede plant growth owing to its content of phytotoxic compounds (Wichuk and McCartney, 2010). Split addition of an N-rich substrate might be less efficient at eradicating weed seeds and producing stable compost than single addition because the newly added substrate will have less time to decompose. However, no studies have been conducted to evaluate the effect of split addition on compost stability and sanitisation.

The objectives of the study were (i) to investigate the effectiveness of split addition of an $\mathrm{N}$-rich substrate on $\mathrm{N}$ losses and GHG emissions during composting using different bulking agents, and (ii) to assess the effect of split addition of an N-rich substrate on sanitisation and compost stability. It was hypothesised that (i) split application of an $\mathrm{N}$-rich substrate reduces total $\mathrm{N}$ loss, with effects varying between bulking agents, (ii) split application of $\mathrm{N}$-rich substrate decreases $\mathrm{CH}_{4}$ emissions, but increases $\mathrm{N}_{2} \mathrm{O}$ emissions from composting, and (iii) split application of an N-rich substrate is effective at eradicating weed seeds and is as efficient at producing stable compost as single addition.

\section{Materials and Methods}

\section{Experimental set-up}

A composting experiment was carried out at the University of Jimma, Ethiopia for $90 \mathrm{~d}$ in $1 \mathrm{~m} \times 1 \mathrm{~m} \times 1 \mathrm{~m}$ boxes made of wood (Juniperus procera). The study area is located at $7^{\circ} 41^{\prime} \mathrm{N}$ latitude, $36^{\circ} 50^{\prime} \mathrm{E}$ longitude and at an average altitude of $1780 \mathrm{~m}$ above sea level. The experiment was conducted in a greenhouse, and the room temperatures in the greenhouse ranged between $20^{\circ} \mathrm{C}$ and $33^{\circ} \mathrm{C}$ throughout the experimental period.

Biodegradable waste containing vegetables was collected from Jimma University's cafeteria. The vegetable mixture had $85 \%$ moisture, total carbon content of $410 \mathrm{~g} \mathrm{~kg}^{-1}$ dry matter and total nitrogen content of $15 \mathrm{~g} \mathrm{~kg}^{-1}$ dry matter. The vegetable wastes were mixed thoroughly with one of two bulking agents on a wet basis ratio of 3:1 (vegetable: bulking agent). The two bulking agents were coffee husks and sawdust both locally available C-rich materials. These materials are also used as bulking agents for composting in many coffee-growing countries (Dias et al., 2010). The coffee husks had a moisture content of $4.6 \%$, a total carbon content of $411 \mathrm{~g} \mathrm{~kg}^{-1}$ dry matter and a total nitrogen content of $12.2 \mathrm{~g} \mathrm{~kg}^{-1}$ dry matter. The sawdust had $5 \%$ moisture, $457 \mathrm{~g} \mathrm{~kg}^{-1} \mathrm{dry}$ matter total carbon and $10.6 \mathrm{~g} \mathrm{~kg}^{-1}$ dry matter total nitrogen. Fresh poultry manure was collected from Jimma University's experimental farm. The poultry manure had $6.4 \%$ moisture, total carbon content of $244 \mathrm{~g} \mathrm{~kg}^{-1}$ dry matter and total nitrogen content of $37.6 \mathrm{~g}$ 
$\mathrm{kg}^{-1}$ dry matter. The poultry manure was added to the vegetable waste and bulking agent mixture on a wet basis ratio of 3:3:1 (poultry manure : vegetable waste : bulking agent). The composting mixture containing coffee husk had a total carbon content of $390 \mathrm{~g} \mathrm{~kg}^{-1}$ dry matter and total nitrogen content of $27 \mathrm{~g} \mathrm{~kg}^{-1}$ dry matter; whereas the mixture containing sawdust had a total carbon content of $420 \mathrm{~g} \mathrm{~kg}^{-1}$ dry matter and a total nitrogen content of $22 \mathrm{~g} \mathrm{~kg}^{-1}$ dry matter.

The poultry manure was added to the composting mixtures in three different ways: (i) all poultry manure was applied at the beginning of composting, (ii) $80 \%$ of the poultry manure was applied at the beginning of composting and the remaining $20 \%$ added after the thermophilic phase, or (iii) $20 \%$ of the poultry manure was applied at the beginning of composting and the remaining $80 \%$ was added after the thermophilic phase. The experiment therefore had two factors: (i) two different bulking agents (i.e. coffee husks and sawdust), and (ii) three distributions of poultry manure application. The experimental design was a completely randomised design arranged as a $3 \times 2$ twoway factorial experiment with three replicates. Details of all treatments are presented in Table 4.1. The compost was turned every two weeks. The moisture content of the pile was adjusted to $60-65 \%$ by spraying water on top. The temperatures were recorded every $2 \mathrm{~h}$ using a temperature data logger (Tinytag View 2-TV-4020, United Kingdom). One data logger was placed in each box at the centre of the pile. In addition to this, the temperature was measured twice a day at different points in the pile. The temperature profile presented in Fig 4.1. is the mean value of the three replicates.

Table 4.1. Codes and detailed descriptions of all treatments

\begin{tabular}{|c|c|}
\hline Code & Descriptions of the treatments \\
\hline C-100 & All poultry manure was applied at the beginning of composting and the bulking agent was coffee husks. \\
\hline C-80/20 & $\begin{array}{l}80 \% \text { of the poultry manure was applied at the beginning of composting and the remaining } 20 \% \text { was } \\
\text { applied after the thermophilic phase. The bulking agent was coffee husks. }\end{array}$ \\
\hline C-20/80 & $\begin{array}{l}20 \% \text { of the poultry manure was applied at the beginning of composting and the remaining } 80 \% \text { was } \\
\text { applied after the thermophilic phase. The bulking agent was coffee husks. }\end{array}$ \\
\hline S-100 & All poultry manure was applied at the beginning of composting and the bulking agent was sawdust. \\
\hline S-80/20 & $\begin{array}{l}80 \% \text { of the poultry manure was applied at the beginning of composting and the remaining } 20 \% \text { was } \\
\text { applied after the thermophilic phase. The bulking agent was sawdust. }\end{array}$ \\
\hline S-20/80 & $\begin{array}{l}20 \% \text { of the poultry manure was applied at the beginning of composting and the remaining } 80 \% \text { was } \\
\text { applied after the thermophilic phase. The bulking agent was sawdust. }\end{array}$ \\
\hline
\end{tabular}




\section{Chemical analyses}

Compost samples were collected at the beginning and end of the experiment for analysis of total carbon, total nitrogen, $\mathrm{NO}_{3}{ }^{-}$and $\mathrm{NH}_{4}{ }^{+}$. The sampling was carried out from five different locations after turning the pile thoroughly. The pile was turned manually to ensure representative sampling. The five samples were then mixed to make a composite sample. Half of the samples were dried $\left(40{ }^{\circ} \mathrm{C}\right)$ and sent to the University of Copenhagen, Denmark, for analysis of total carbon and total nitrogen. Total carbon and total nitrogen were determined using an elemental analyser coupled to an isotope ratio mass spectrometer (PYRO Cube from Elementar, Germany coupled to an Isoprime100 IRMS, UK). The remaining samples were stored at $-18{ }^{\circ} \mathrm{C}$ for $\mathrm{NH}_{4}{ }^{+}$and $\mathrm{NO}_{3}{ }^{-}$ measurements. The $\mathrm{NH}_{4}{ }^{+}$and $\mathrm{NO}_{3}$ - concentrations were measured as described by Bryndum (2014). Briefly, compost samples were mixed with $1 \mathrm{M} \mathrm{KCl}$ in a 1:100 compost : solution ratio $(\mathrm{w} / \mathrm{v})$ and shaken for $1 \mathrm{~h}$. The extracts were then analysed for $\mathrm{NH}_{4}{ }^{+}$and $\mathrm{NO}_{3}{ }^{-}$concentrations using a flow injection analyser (FIA star TM 5000 analyser, Denmark). Water-extractable $\mathrm{C}$ was determined using ultra-pure water, as described by Straathof and Comans (2015). Briefly, fresh compost was mixed with ultra-pure milli-Q water at a 1:10 ratio $(\mathrm{w} / \mathrm{v})$, shaken for $1 \mathrm{~h}$ on the horizontal shaker and filtered through $0.45 \mu \mathrm{m}$ (Whatman TM). Due to the heterogeneity of the compost samples, each sample was replicated four times and the replicates were finally pooled together after the extracts had been filtered through $0.45 \mu \mathrm{m}$. A sub-sample $(5 \mathrm{ml})$ was then taken and analysed for DOC quantity using San ${ }^{++}$channel SFA (SKALAR, The Netherlands). The final and initial total $\mathrm{N}$ concentrations were used to calculate the $\mathrm{N}$ loss during composting as:

$$
\text { Fractional nitrogen loss }=\left(\frac{Q_{i} C_{i}-Q_{f} C_{f}}{Q_{i}}\right) \times 100
$$

where $Q_{i}$ and $Q_{f}$ are total dry mass $(\mathrm{kg})$ of the vegetable waste-bulking material-manure mixture that was added during the experiment and remained at the end of the experiment respectively, and $C_{i}$ and $C_{f}$ are nitrogen concentrations that were added during the experiment and remained at the end of the experiment respectively.

\section{Gas sampling}

The static-chamber method was used to collect gas samples (Chan et al., 2011). For gas sampling, a $20 \mathrm{~L}$ polyethylene gas chamber equipped with a rubber stopper was inserted $2 \mathrm{~cm}$ into the composting materials. The rim of the chamber was then covered in the composting material and water applied around it to provide a good air seal. Two mini fans $(12 \mathrm{~V})$ were installed in the polyethylene chamber to ensure homogeneous distribution of air in the headspace. Gas samples were collected by syringe every $2 \mathrm{~d}$ for the first week after the addition of substrates, and then once a week until the end of the 
experiment. Gas samples were collected at three time points $(0,20,40 \mathrm{~min})$ and injected into $3 \mathrm{ml}$ screw-capped evacuated Exetainer ${ }^{\circledR}$ vials. Gas samples were also collected at 0 , $20,40,60,80$ and 100 min every month in order to check the linearity assumption. The gas samples were analysed at the University of Copenhagen using gas chromatography (Bruker 450- GC 2011, United Kingdom). The emissions rate in $\mathrm{mg} \mathrm{kg}^{-1}$ initial dry matter was calculated as:

Emission rate $=\left(\frac{\Delta \mathrm{C}}{\Delta \mathrm{t}}\right) *\left(\frac{\mathrm{V}}{\mathrm{W}}\right) *\left(\frac{\mathrm{M}}{\mathrm{Vs}}\right) *\left(\frac{\mathrm{P}}{\mathrm{Po}}\right) *\left(\frac{273}{\mathrm{~T}}\right) *\left(\frac{\mathrm{A} 1}{\mathrm{~A} 2}\right)$

where $\Delta \mathrm{C}$ is the change in concentration of gas (ppm) during time interval $\Delta \mathrm{t}$ in $\mathrm{d}, \mathrm{V}$ is the headspace volume $(\mathrm{L}), \mathrm{M}$ is the molecular mass of the gas of interest $(44,16$ and $44 \mathrm{~g}$ for $\mathrm{CO}_{2}, \mathrm{CH}_{4}$ and $\mathrm{N}_{2} \mathrm{O}$, respectively), $\mathrm{Vs}$ is the volume occupied by $1 \mathrm{M}$ of a gas at standard temperature and pressure $(22.4 \mathrm{~L}), \mathrm{P}$ is the atmospheric pressure (bar), Po is the standard pressure (1.013 bar), $\mathrm{T}$ is the temperature inside the chamber during the deployment time in Kelvin, A1 and A2 are the area $\left(\mathrm{m}^{2}\right)$ of the composting container and chamber respectively, and $\mathrm{W}$ is the initial dry mass of the composting material $(\mathrm{kg})$.

The cumulative emissions were calculated using the trapezoid formula (equation 3) (Ly et al., 2013):

$$
A_{t(a b)}=\frac{\left(t_{b}-t_{a}\right) \cdot\left(F_{t a}+F_{t b}\right)}{2}
$$

where $A_{t(a b)}$ is the cumulative emission between the measurement days (between ta and $\left.t_{b}\right), t_{a}$ and $t_{b}$ are the dates of the two measurements, and $F_{t a}$ and $F_{t b}$ are the gas fluxes at the two measurement dates.

Therefore, the total cumulative emission was calculated as the sum of cumulative emissions on each day using equation 4:

Total cumulative emission $=\sum \mathrm{A}_{\mathrm{t}(\mathrm{ab})}$

The global warming potential ( $\mathrm{CO}_{2}$-equivalents) of each treatment was calculated by multiplying total cumulative $\mathrm{CH}_{4}$ and $\mathrm{N}_{2} \mathrm{O}$ emissions by 34 and 298 respectively (IPCC, 2013). The $\mathrm{CO}_{2}$ emission from composting is considered a biogenic gas (Vu et al., 2015) and hence is not included in the global warming potential of the process (Yang et al., 2013).

\section{Seed germination}

Seeds of four weed species, namely Parthenium hysterophorus, Digitaria abyssinica, Lantana camara and Solanum marginatum, were used. These weeds are common in many parts of the tropics and subtropics. Small nylon-mesh bags $(4 \mathrm{~cm} \times 4 \mathrm{~cm})$ were prepared and 20 seeds of each species placed in separate bags. The nylon bags were then put deep in the 
compost piles. At the end of the experiment, the nylon bags were retrieved and the seeds tested for germination. For germination tests, the seeds were placed in $90 \mathrm{~mm}$ Petri dishes with moistened filter paper. The Petri dishes were sealed using paraffin film to reduce moisture loss and then placed in an incubator at $25{ }^{\circ} \mathrm{C}$. Germination was periodically recorded for three weeks, after which time $5 \mathrm{ml}$ of $0.2 \% \mathrm{KNO}_{3}$ was added to promote further germination. The seeds were kept in an incubator for a further two weeks.

\section{Phytotoxicity assay}

The germination test was conducted in three replicates to assess the phytotoxicity of the composts. Twenty-five barley (Hordeum vulgare) seeds were placed in $90 \mathrm{~mm}$ Petri dishes, moistened with $5 \mathrm{ml}$ of the compost extracts and incubated at $20^{\circ} \mathrm{C}$ for $3 \mathrm{~d}$. The extract was prepared from fresh compost using ultra-pure milli-Q water at a 1:10 ratio $(\mathrm{w} / \mathrm{v})$, shaken for $1 \mathrm{~h}$ on the horizontal shaker and filtered through $0.45 \mu \mathrm{m}$ (Whatman TM). Similarly, a control was prepared from ultra-pure milli-Q water. The germination test was then calculated as:

$$
\text { Relative seed germination }(\%)=\left[\frac{(\text { No. of seeds germinated in compost extract })}{(\text { No. of seeds germinated in control })}\right] \times 100
$$

\section{Design of the incubation experiment}

The incubation experiment was undertaken to determine compost stability and $\mathrm{N}$ mineralisation after soil application of the composts. Soils were collected from the plough layer of agricultural fields (Tasstrup, Denmark) which for over 30 years had only received mineral fertilisers. The soil samples were air-dried and sieved to $\leq 2 \mathrm{~mm}$. The soil was a sandy clay loam (clay $15 \%$, silt $18 \%$, sand $65 \%$ ) with a C content of $1.15 \%$, total $\mathrm{N}$ content of $0.13 \%$ and a $\mathrm{pH}\left(\mathrm{CaCl}_{2}\right)$ value of 5.6. Fifty grams of soil were added to 100 $\mathrm{ml}$ polyethylene cups, wetted to $60 \%$ water-holding capacity (WHC) and pre-incubated for two weeks. After that time, the composts - produced with different timings of substrate addition (Table 4.1) - were applied to the incubated soils at a rate of $5 \%$ (dry weight basis) and mixed thoroughly. The treatments were replicated three times. The soil and compost mixtures were packed to $1.2 \mathrm{~g} \mathrm{~cm}^{-3}$ and the moisture content was adjusted to $60 \%$ WHC using milli-Q water. Soil without compost was packed to the same density and moisture content, and then used as a control. The experiment was conducted in the dark at a temperature of $15^{\circ} \mathrm{C}$. The weight of the cups was checked every week, and the water loss was adjusted by adding milli-Q water.

During gas sampling, the cups were placed in an airtight $0.9 \mathrm{~L}$ Kilner jar equipped with a rubber stopper and $5 \mathrm{ml}$ gas samples were collected after 0,60 and $120 \mathrm{~min}$ using an air-tight syringe and injected into $3 \mathrm{ml}$ screw-capped Exetainer ${ }^{\circledR}$ vials. The samples 
were analysed for $\mathrm{CO}_{2}$ concentration using gas chromatography (Bruker 450-GC 2011, United Kingdom). The gas samples were collected every $2 \mathrm{~d}$ for the first week and then once a week until the end of the experiment. The $\mathrm{CO}_{2}$ emissions were calculated from the increase in $\mathrm{CO}_{2}$ concentration inside the Kilner jars, assuming a linear increase in $\mathrm{CO}_{2}$ concentration during sampling. The linearity assumption was checked once a month by collecting gas samples at $0,20,40,60,80$ and $100 \mathrm{~min}$.

Two destructive soil samples were collected at 21 and $60 \mathrm{~d}$ from the sub-set of each treatment. The $\mathrm{NH}_{4}{ }^{+}$and $\mathrm{NO}_{3}$ concentrations were extracted using $1 \mathrm{M} \mathrm{KCl}$ solution. Briefly, $20 \mathrm{~g}$ of sample (dry matter basis) was mixed with $80 \mathrm{ml}$ of $1 \mathrm{M} \mathrm{KCl}$, shaken for $1 \mathrm{~h}$, filtered and stored at $-18{ }^{\circ} \mathrm{C}$. The $\mathrm{NH}_{4}{ }^{+}$and $\mathrm{NO}_{3}{ }^{-}$concentrations were analysed from the extract using flow injection analysis (FIA star TM 5000 analyser, Denmark).

\section{Statistical analyses}

All treatments (i.e. both the composting and incubation experiments) were arranged in a completely randomised design, and two-way analysis of variance (ANOVA) was performed. Tukey tests were used to compare the treatment means if the factors' effect was significant at $\mathrm{P}<0.05$. All statistical analyses were carried out using SAS version 9.2 statistical package.

\section{Results}

\section{Temperature profile}

The temperature throughout the composting period is shown in Figure 4.1. The thermophilic phase was reached within one week for all treatments and lasted for more than three weeks. The peak temperatures were between 55 and $63{ }^{\circ} \mathrm{C}$ and between 52 and $55{ }^{\circ} \mathrm{C}$ respectively when coffee husks and sawdust were used as the bulking agent. The timing of the addition of the N-rich substrate did not affect the temperature in the first active phase of the composting, but split addition resulted in a second temperature peak, which lasted for less than two weeks. 

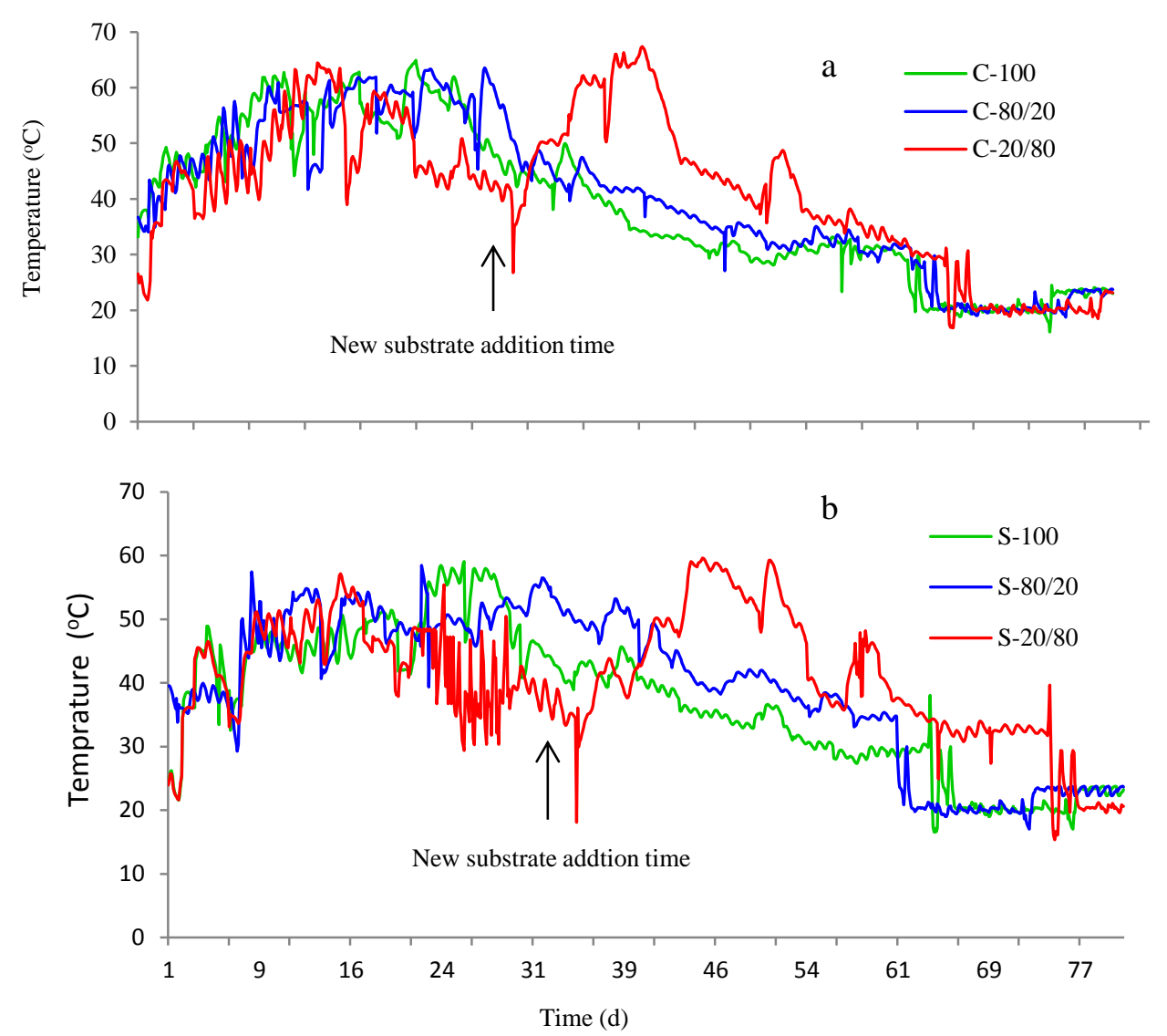

Figure 4.1. Temperature profiles during the composting of household waste and poultry manure. (a) Substrates with coffee husks, and (b) substrates with sawdust; $\mathrm{C}=$ coffee husks, $\mathrm{S}=$ sawdust; $\mathrm{C}-100$ and/or S-100 = all poultry manure was applied at the beginning of composting; C-80/20 and/or S-80/20 $=80 \%$ of the poultry manure was applied at the beginning of composting and the remaining $20 \%$ was added after the thermophilic phase; C-20/80 and/or S-20/80 $=20 \%$ of the poultry manure was applied at the beginning of composting and the remaining $80 \%$ was added after the thermophilic phase; arrows indicate the time of the second substrate addition.

\section{Nitrogen loss and mineralisation during composting}

Total $\mathrm{N}$ loss varied depending on the timing of the addition of the $\mathrm{N}$-rich substrate $(\mathrm{P}=$ $0.003)$ and on the bulking agent $(\mathrm{P}<0.001)$, whereas the interaction was marginally significant $(\mathrm{P}=0.06$; Table 4.2). The highest $\mathrm{N}$ losses were observed when all of the $\mathrm{N}$ rich substrate was added at the beginning of composting, irrespective of the bulking agent. Split addition of the $\mathrm{N}$-rich substrate reduced total $\mathrm{N}$ loss by up to $20 \%$ with coffee husks containing substrates, and by up to $9 \%$ with sawdust containing substrates (Fig. 4.2). The $\mathrm{NO}_{3}{ }^{-}$concentration after $90 \mathrm{~d}$ of composting period was affected by the timing of the $\mathrm{N}$-rich substrate addition $(\mathrm{P}=0.01)$ and bulking agent $(\mathrm{P}<0.001)$ (Table 4.3). When $20 \%$ of $\mathrm{N}$-rich substrate was applied at first application (i.e. the 20/80 treatments), the $\mathrm{NO}_{3}{ }^{-}$concentration increased by $60 \%$ and $123 \%$ with coffee husk and sawdust-containing substrates respectively. Timing of the N-rich substrate addition had a marginal effect on the $\mathrm{NH}_{4}{ }^{+}$concentration of the final product $(\mathrm{P}=0.06)$, but the $\mathrm{NH}_{4}{ }^{+}$concentration differed 


\section{Chapter 4}

between bulking agents $(\mathrm{P}<0.001)$ and there was a significant interaction between bulking agent and the timing of the addition of the $\mathrm{N}$-rich substrate $(\mathrm{P}=0.03)$.

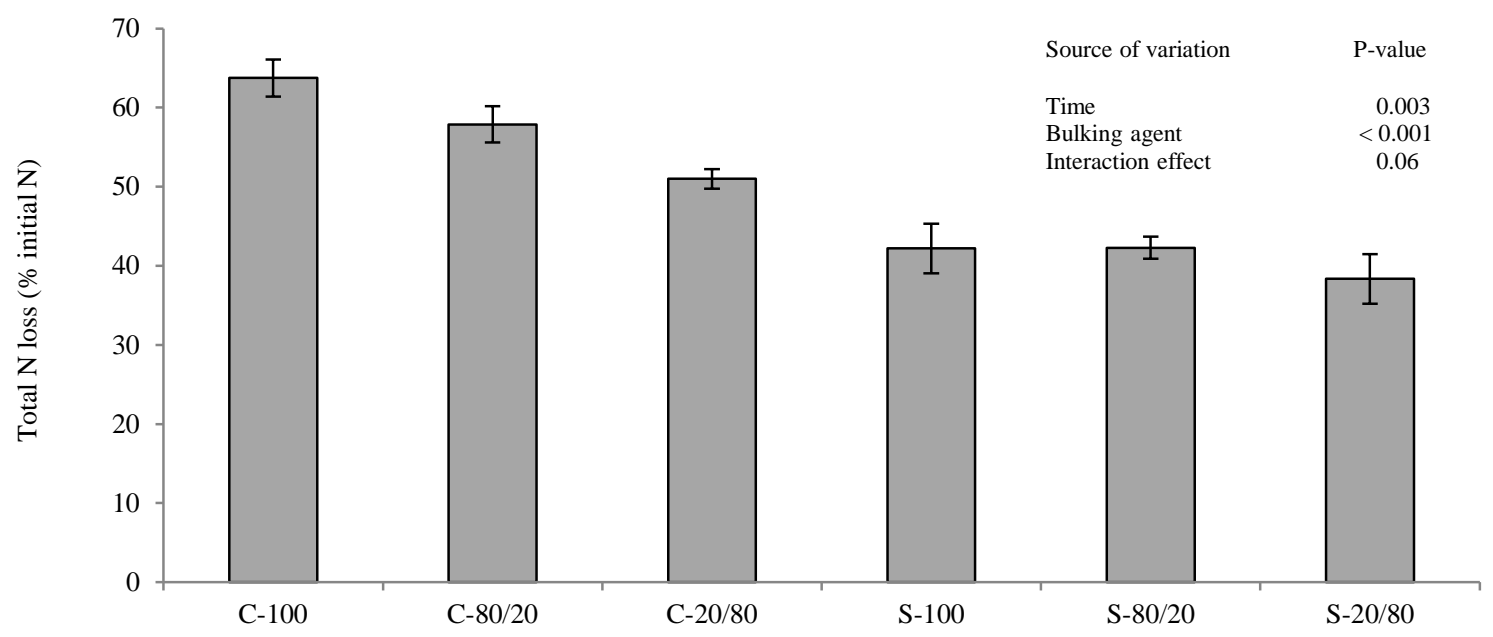

Figure 4.2. Total nitrogen loss after $90 \mathrm{~d}$ of composting period. $\mathrm{C}=$ coffee husks, $\mathrm{S}=$ sawdust; $\mathrm{C}-100$ and/or S-100 = all poultry manure was applied at the beginning of composting; C-80/20 and/or S-80/20 $=80 \%$ of poultry manure was applied at the beginning of composting and the remaining $20 \%$ was added after the thermophilic phase; C-20/80 and/or S-20/80 $=20 \%$ of the poultry manure was applied at the beginning of composting and the remaining $80 \%$ was added after the thermophilic phase.

Table 4.2. Carbon and nitrogen mass balances after $90 \mathrm{~d}$ of composting period (mean \pm standard error of the mean; $\mathrm{n}=3$ )

$\begin{array}{cccccccc}\text { Treatment } & \text { Total carbon } & \text { Carbon } & \text { Carbon } & \text { Carbon } & \text { Total } \mathrm{N} & \mathrm{N} \text { loss } & \mathrm{N} \text { loss } \\ & \text { loss } & \text { loss } & \text { loss } & \text { unaccounted } & \text { retained } & \left(\mathrm{N}_{2} \mathrm{O}-\mathrm{N}\right) & \left(\mathrm{NH}_{3}, \mathrm{~N}_{2}, \mathrm{NO}_{x}\right) \\ & & \left(\mathrm{CO}_{2}-\mathrm{C}\right) & \left(\mathrm{CH}_{4}-\mathrm{C}\right) & \text { for } & & & \end{array}$

\begin{tabular}{lccccccc}
\hline C_100 & $65.5 \pm 0.6$ & $48.9 \pm 1.6$ & $0.08 \pm 0.03$ & $16.6 \pm 2.0$ & $36.3 \pm 2.4$ & $0.02 \pm 0.01$ & $63.7 \pm 2.4$ \\
C_80/20 & $59.2 \pm 3.0$ & $36.1 \pm 5.9$ & $0.10 \pm 0.03$ & $23.0 \pm 4.8$ & $42.1 \pm 2.2$ & $0.13 \pm 0.04$ & $57.8 \pm 2.2$ \\
C_20/80 & $57.3 \pm 3.3$ & $31.0 \pm 4.2$ & $0.07 \pm 0.01$ & $26.2 \pm 1.0$ & $50.4 \pm 1.2$ & $0.18 \pm 0.03$ & $49.4 \pm 1.2$ \\
S_100 & $54.3 \pm 2.3$ & $33.8 \pm 4.7$ & $0.14 \pm 0.02$ & $20.3 \pm 3.9$ & $57.8 \pm 3.2$ & $0.32 \pm 0.07$ & $41.9 \pm 3.1$ \\
S_80/20 & $54.7 \pm 3.1$ & $29.6 \pm 1.0$ & $0.20 \pm 0.01$ & $24.7 \pm 3.7$ & $52.2 \pm 1.4$ & $0.34 \pm 0.03$ & $47.5 \pm 1.4$ \\
S_20/80 & $52.9 \pm 2.7$ & $31.5 \pm 1.0$ & $0.05 \pm 0.02$ & $21.4 \pm 2.2$ & $61.6 \pm 3.1$ & $0.40 \pm 0.03$ & $38.0 \pm 3.1$ \\
\hline ANOVA & & & & & & & 0.03 \\
\hline T & 0.23 & 0.01 & $<0.001$ & 0.54 & 0.003 & 0.04 & 0.003 \\
B & 0.01 & 0.01 & 0.01 & 0.68 & $<0.001$ & $<0.001$ & $<0.001$ \\
T*B & 0.38 & 0.01 & 0.01 & 0.62 & 0.06 & 0.55 & 0.06 \\
\hline
\end{tabular}

$\mathrm{C}=$ coffee husks, $\mathrm{S}=$ sawdust; $\mathrm{C}-100$ and/or S-100 = all poultry manure was applied at the beginning of composting; C$80 / 20$ and/or S- $80 / 20=80 \%$ of the poultry manure was applied at the beginning of composting and the remaining $20 \%$ was added after the thermophilic phase; C-20/80 and/or S-20/80 $=20 \%$ of the poultry manure was applied at the beginning of composting and the remaining $80 \%$ was added after the thermophilic phase; $\mathrm{T}=$ timing of $\mathrm{N}$-rich substrate addition; $\mathrm{B}=$ bulking agent; $\mathrm{T}^{*} \mathrm{~B}=$ treatments interaction effect. 
Table 4.3. Chemical properties of the composts after $90 \mathrm{~d}$ of composting period (mean \pm standard error of the mean; $n=3$ )

\begin{tabular}{|c|c|c|c|c|c|c|}
\hline Treatment & Total carbon & Total nitrogen & $\mathrm{NO}_{3-}$ & $\mathrm{NH}_{4}{ }^{+}$ & $\mathrm{Cw}$ & Germination \\
\hline & & & kg-1 dry & 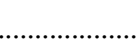 & ...... & (\% control) \\
\hline C_100 & $323.4 \pm 5.3$ & $23.0 \pm 0.14$ & $0.6 \pm 0.06$ & $0.7 \pm 0.02$ & $10.52 \pm 0.40$ & 98 \\
\hline C_80/20 & $319.2 \pm 4.6$ & $26.4 \pm 0.15$ & $0.8+0.03$ & $0.6 \pm 0.03$ & $11.06+0.56$ & 99 \\
\hline C_20/80 & $349.5+23.2$ & $29.7 \pm 0.10$ & $1.2+0.04$ & $1.1 \pm 0.01$ & $12.74+2.77$ & 93 \\
\hline S_100 & $337.9 \pm 15.8$ & $21.9 \pm 0.13$ & $0.1 \pm 0.02$ & $0.08 \pm 0.01$ & $6.99 \pm 0.17$ & 96 \\
\hline S_80/20 & $351.4 \pm 24.0$ & $23.1 \pm 0.06$ & $0.1 \pm 0.01$ & $0.08 \pm 0.01$ & $7.18 \pm 1.24$ & 93 \\
\hline S_20/80 & $363.3 \pm 18.7$ & $24.8 \pm 0.13$ & $0.6 \pm 0.07$ & $0.1 \pm 0.01$ & $7.87 \pm 1.12$ & 99 \\
\hline \multicolumn{7}{|l|}{ ANOVA } \\
\hline $\mathrm{T}$ & 0.23 & 0.01 & 0.01 & 0.06 & 0.54 & 0.28 \\
\hline B & 0.75 & 0.01 & $<0.001$ & $<0.001$ & 0.01 & 0.94 \\
\hline $\mathrm{T}^{*} \mathrm{~B}$ & 0.67 & 0.10 & 0.35 & 0.03 & 0.90 & 0.89 \\
\hline
\end{tabular}

$\mathrm{T}=$ timing of $\mathrm{N}$-rich substrate addition; $\mathrm{B}=$ bulking agent; $\mathrm{T}^{*} \mathrm{~B}=$ interaction between timing of N-rich substrate addition and bulking agent; $\mathrm{C}=$ coffee husks, $\mathrm{S}=$ sawdust; $\mathrm{C}-100$ and/or S-100 = all poultry manure was applied at the beginning of composting; C- $80 / 20$ and/or S- $80 / 20=80 \%$ of the poultry manure was applied at the beginning of composting and the remaining $20 \%$ was added after the thermophilic phase; C-20/80 and/or S-20/80 $=20 \%$ of the poultry manure was applied at the beginning of composting and the remaining $80 \%$ was added after the thermophilic phase; $\mathrm{Cw}=$ water extractable organic $\mathrm{C} ; \mathrm{T}=$ timing of $\mathrm{N}$-rich substrate addition; $\mathrm{B}=$ bulking agent; $\mathrm{T}^{*} \mathrm{~B}=$ treatments interaction effect.

\section{Greenhouse gas emissions}

The effect of split addition of the N-rich substrate on cumulative GHG emissions is presented in Figure 4.3. Analysis of variance showed that cumulative $\mathrm{CO}_{2}$ emissions were significantly affected by the timing of the $\mathrm{N}$-rich substrate addition $(\mathrm{P}=0.01)$ and bulking agent $(\mathrm{P}=0.02)$, and that there was a significant interaction between the two factors $(\mathrm{P}=0.004)$. Application of all the $\mathrm{N}$-rich substrate at the beginning resulted in higher cumulative $\mathrm{CO}_{2}$ emissions compared with split application, and this effect was more pronounced with the substrates containing coffee husks (Fig. 4.3a). Split addition of $\mathrm{N}$-rich substrates affected total cumulative $\mathrm{CH}_{4}$ emissions $(\mathrm{P}=0.05)$ and there was a significant interaction between the timing of the addition of the N-rich substrate and the bulking agent $(\mathrm{P}=0.05)$. Regardless of the bulking agent used, the highest $\mathrm{CH}_{4}$ emissions were observed when $80 \%$ of the $\mathrm{N}$-rich substrate was added at the beginning of composting (i.e. 80/20 treatments) (Fig. 4.3b). The timing of N-rich substrate addition and bulking agents affected cumulative $\mathrm{N}_{2} \mathrm{O}$ emissions $(\mathrm{P}=0.03$ and $\mathrm{P}<0.001$ respectively). The $20 / 80$ treatments increased cumulative $\mathrm{N}_{2} \mathrm{O}$ emissions by $600 \%$ with coffee husks as the bulking agent, and by $25 \%$ with sawdust as the bulking agent (Fig. $4.3 \mathrm{c}$ ) compared to single addition. The total GHG budget (i.e. non- $\mathrm{CO}_{2} \mathrm{GHG}$ (Fig. 4.3d) varied between the bulking agents $(\mathrm{P}=0.001)$, but the timing of substrate addition had a marginal effect $(\mathrm{P}=$ 0.06). Total greenhouse gas emissions were higher with coffee husks than with sawdust. When $\mathrm{CO}_{2}$ was accounted for in the total GHG budget, the total GHG emissions varied 
between the timing of substrate addition $(\mathrm{P}=0.01)$ and the treatment interactions $(\mathrm{P}=$ $0.05)$, but the effect of bulking agent was non-significant $(\mathrm{P}=0.16)$ (Fig 4.3e). In this scenario, early addition of N-rich substrate increased the total GHG budget compared with delayed addition.
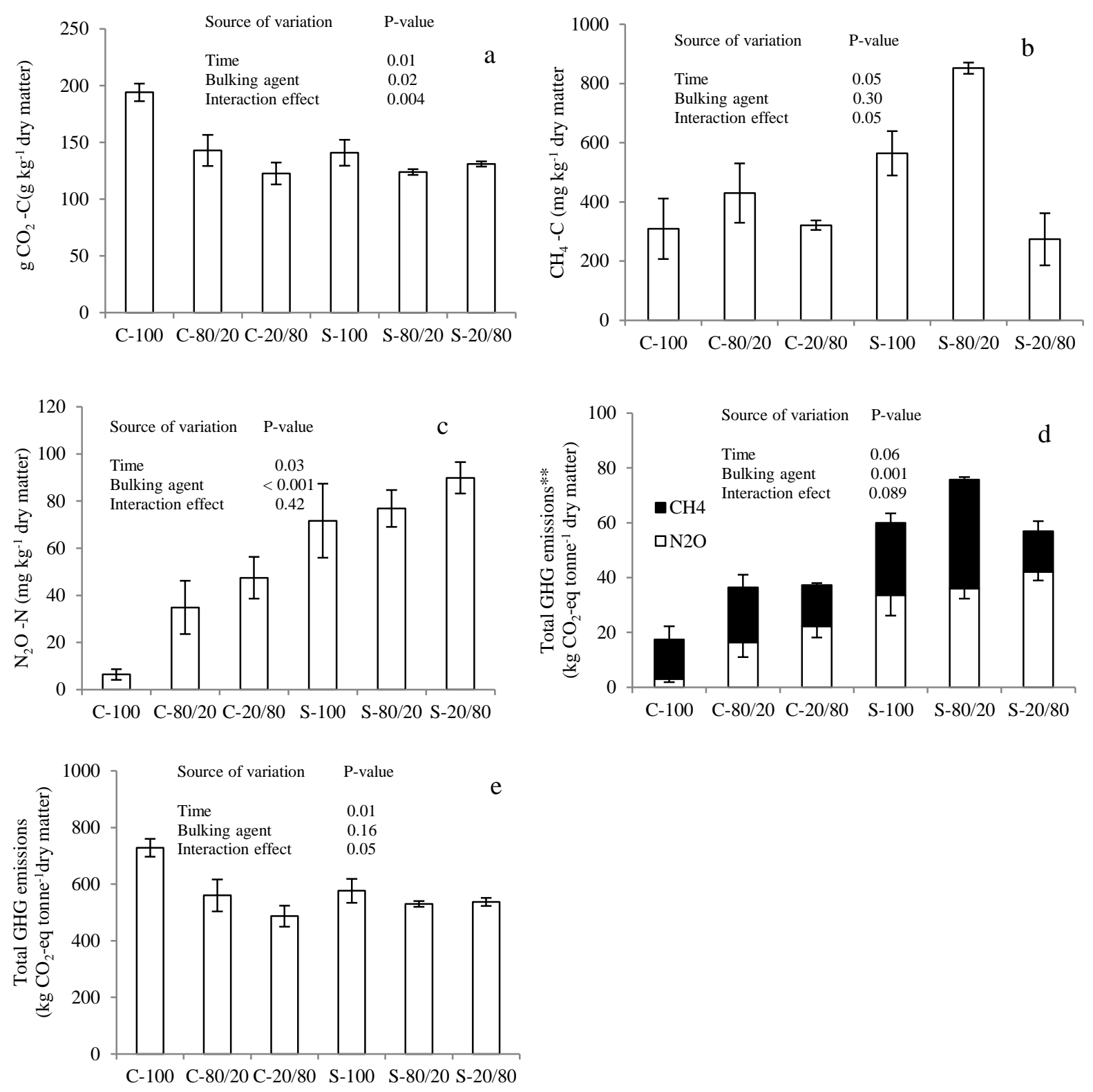

Figure 4.3. Total cumulative GHG emissions after $90 \mathrm{~d}$ of composting period. (a) $\mathrm{CO}_{2}-\mathrm{C}$, (b) $\mathrm{CH}_{4}-\mathrm{C}$, (c) $\mathrm{N}_{2} \mathrm{O}-\mathrm{N}$ (d) total GHG emissions excluding $\mathrm{CO}_{2}$, (e) total GHG emissions including $\mathrm{CO}_{2} ; \mathrm{C}=$ coffee husks, $\mathrm{S}=$ sawdust; $\mathrm{C}-100$ and/or S-100 = all poultry manure was applied at the beginning of composting; C- $80 / 20$ and/or S- $80 / 20=80 \%$ of the poultry manure was applied at the beginning of composting and the remaining $20 \%$ was added after the thermophilic phase; C-20/80 and/or S-20/80 = $20 \%$ of the poultry manure was applied at the beginning of composting and the remaining $80 \%$ was added after the thermophilic phase; ${ }^{* *}$ indicates non- $\mathrm{CO}_{2} \mathrm{GHG}$ emissions. 


\section{$\mathrm{C}$ and $\mathrm{N}$ mineralisation after soil application}

$\mathrm{CO}_{2}$ evolution from the composts after soil application is presented in Figure 4.4. The timing of $\mathrm{N}$-rich substrate addition and bulking agent affected $\mathrm{C}$ mineralisation $(\mathrm{P}=0.03$ and $\mathrm{P}=0.002$ respectively). Postponing the addition of $\mathrm{N}$-rich substrate increased $\mathrm{CO}_{2}$ emissions after soil application, irrespective of the bulking agent used, indicating lower compost maturity. The $\mathrm{NO}_{3}{ }^{-}$concentration differed between soils incubated with compost produced with a different timing of N-rich substrate addition $(\mathrm{P}=005)$ and bulking agent $(P<0.001)$, and there was also a significant interaction $(P=0.02)$ (Supplementary Fig. 4.1). After $60 \mathrm{~d}$ of incubation, late addition of the N-rich substrate increased the $\mathrm{NO}_{3}$ - concentration by $20 \%$ and $74 \%$ with coffee husks and sawdust respectively compared to single addition. The $\mathrm{NH}_{4}{ }^{+}$concentration, however, was not affected by the treatments.

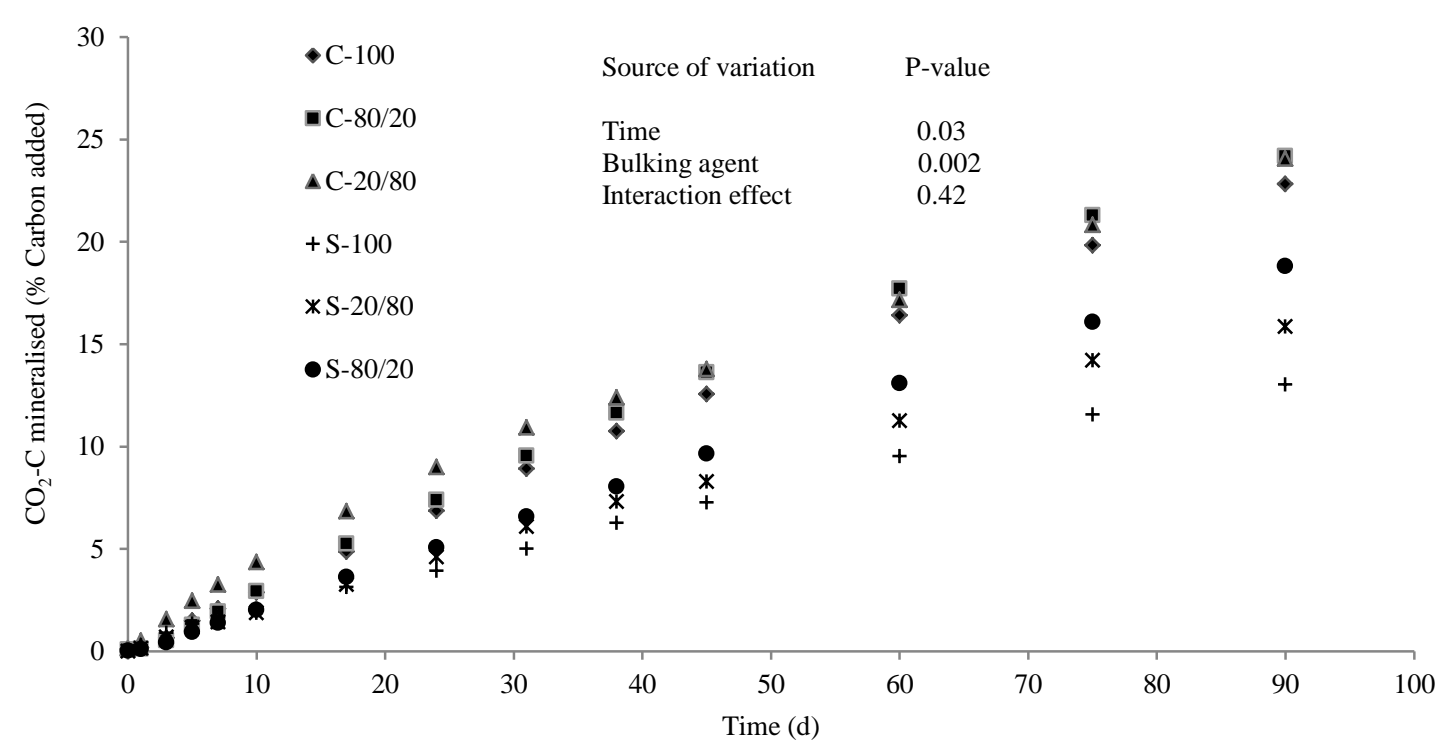

Figure 4.4. Cumulative $\mathrm{CO}_{2}-\mathrm{C}$ emissions from soil during a $90 \mathrm{~d}$ of incubation period. $\mathrm{C}=$ coffee husks, $\mathrm{S}=$ sawdust; C-100 and/or S-100 = all poultry manure was applied at the beginning of composting; C$80 / 20$ and/or S- $80 / 20=80 \%$ of the poultry manure was applied at the beginning of composting and the remaining $20 \%$ was added after the thermophilic phase; C-20/80 and/or S-20/80 $=20 \%$ of the poultry manure was applied at the beginning of composting and the remaining $80 \%$ was added after the thermophilic phase.

\section{Weed seed germination}

The seeds of Parthenium hysterophorus and Digitaria abyssinica had decomposed completely after $60 \mathrm{~d}$ of composting. Some Lantana camara and Solanum marginatum seeds were recovered, even after $90 \mathrm{~d}$ of composting, however the seeds did not germinate. Thus all of the treatments prevented weed emergence after $90 \mathrm{~d}$ of composting. The phytotoxicity assay (Table 4.3 ) showed that the timing of N-rich substrate addition and bulking agent did not affect the germination of Hordeum vulgare seeds. 


\section{Discussion}

\section{Relative nitrogen loss}

Postponing the addition of the N-rich substrate reduced total $\mathrm{N}$ loss irrespective of the bulking agent, as hypothesised. The total $\mathrm{N}$ loss observed in this study ranged from $40 \%$ to $60 \%$ of the initial $\mathrm{N}$ content, and was comparable with earlier studies (Bernal et al., 2009; Steiner et al., 2010), but higher than other studies (Yang et al., 2013). The high N losses in this study could be explained by the high temperatures, the long duration of the thermophilic phase (Fig. 4.1), the high $\mathrm{NH}_{4}{ }^{+}$concentration and $\mathrm{C}$ loss (Table 4.2 and 4.3) and the relatively open design of the composting containers. The $\mathrm{N}$ loss as $\mathrm{N}_{2} \mathrm{O}$ was less than $1 \%$ for all treatments (Table 4.2), and $\mathrm{N}$ loss via leaching was minimised by controlling the moisture content throughout the experimental period. The majority of $\mathrm{N}$ losses could therefore be explained by ammonia emissions and $\mathrm{N}_{2}$ losses (Table 4.2). It is well known that temperatures above $45^{\circ} \mathrm{C}$ increase ammonia volatilisation dramatically (Pagans et al., 2006). In this experiment, the thermophilic phase $\left(>45^{\circ} \mathrm{C}\right)$ lasted for more than three weeks (Fig. 4.1) and the $\mathrm{NH}_{4}{ }^{+}$concentration was $>1000 \mathrm{mg} \mathrm{kg}^{-1}$ dry matter for all treatments, implying the presence of optimal conditions for ammonia volatilisation. The high initial concentration of $\mathrm{NH}_{4}{ }^{+}$when all the $\mathrm{N}$-rich substrate was added at the beginning was therefore more prone to $\mathrm{NH}_{3}$ volatilisation than the split treatments. Split addition of N-rich substrate resulted in a second temperature peak, but this temperature lasted for less than two weeks. Consequently, when the addition of the N-rich substrate was postponed, the majority of $\mathrm{N}$ added was exposed to a lesser extent to conditions that are conducive to volatilisation. In agreement with these findings, Bryndum (2014) reported a 33\% reduction in $\mathrm{N}$ loss due to the delayed addition of $\mathrm{N}$-rich substrates (i.e. poultry manure) from composting of sugarcane bagasse and filter cake. Dresbøll and Thorup-Kristensen (2005), however, did not observe a significant effect of split addition of clover on $\mathrm{N}$ loss from composting of wheat straw and clover. These contradictory results are probably due to the differences in $\mathrm{NH}_{4}{ }^{+}$concentration, temperature and materials used for composting. For instance, there are higher levels of ammonium and easily mineralisable nitrogen compounds in poultry manure than in clover, which contains mainly organic nitrogen. The $\mathrm{NH}_{4}{ }^{+}$concentration was $<400 \mathrm{mg} \mathrm{kg}^{-1}$ dry matter during the earlier study (Dresbøll and Thorup-Kristensen, 2005). Hence, the effect of split application is less in clover because nitrogen has to be mineralised before it can volatilise. Furthermore, the thermophilic phase only lasted for two weeks in the previous study (Dresbøll and Thorup-Kristensen, 2005), which could have resulted in less ammonia volatilisation compared to the present experiment. The effect of delayed addition of $\mathrm{N}$ rich substrate on $\mathrm{N}$ loss was not as great as expected and/or reported by Bryndum (2014). This variation is explained by the second thermophilic phase, which was observed in the present study, but not by Bryndum (2014). The second thermophilic phase might result 
in high $\mathrm{N}$ losses, but these high temperatures are crucial for compost sanitisation. It is hypothesised that splitting the N-rich substrate more than twice might further reduce total $\mathrm{N}$ loss, and this hypothesis should be investigated.

The effect of split addition on $\mathrm{N}$ loss varied between both bulking materials $(\mathrm{P}<$ 0.001). These variations could be explained by the higher temperatures $\left(55-63{ }^{\circ} \mathrm{C}\right)$ when coffee husks rather than sawdust were used (52-55 $\left.{ }^{\circ} \mathrm{C}\right)$ (Fig. 4.1), which subsequently led to higher ammonia volatilisation. High $\mathrm{N}$ immobilisation could be another explanation for the minimum effect of split addition with the substrates containing sawdust because the higher $\mathrm{C}: \mathrm{N}$ ratio of this mixture may have efficiently immobilised ammonium. The total $\mathrm{N}$ loss was correlated with organic matter and/or $\mathrm{C}$ loss during the composting process $\left(\mathrm{r}^{2}=0.78 ; \mathrm{P}<0.001\right)$. The higher $\mathrm{C}$ loss with coffee husk substrate compared to sawdust substrate (Table 4.2) could therefore be an explanation for the observed differences in total $\mathrm{N}$ losses between the two bulking materials. In agreement with these findings, Dias et al. (2009) observed N loss with substrate containing coffee husks that was three times higher than with sawdust. To the authors' knowledge, this is the first study that has investigated the interactions between the timing of N-rich substrate addition and bulking agent on $\mathrm{N}$ loss. Further studies are needed to investigate the effectiveness of split substrate addition under different composting conditions, such as substrate quality, moisture content, aeration and other variables. Split addition of N-rich substrates also increased mineral $\mathrm{N}$ content in the final product after soil application, as hypothesised. Immobilisation and ammonia loss explained the observed variations between the treatments in mineral $\mathrm{N}$ concentrations. The mineral $\mathrm{N}$ concentrations in the soil after 21 and $60 \mathrm{~d}$ of incubation agreed with the inorganic $\mathrm{N}$ concentration of the composts (Table 4.3).

\section{Greenhouse gas emissions}

The hypothesis that split addition of an N-rich substrate increases $\mathrm{N}_{2} \mathrm{O}$ emissions was confirmed. Both nitrifying and denitrifying bacteria are mesophilic, and high temperatures effectively reduce $\mathrm{N}_{2} \mathrm{O}$ production ( $\mathrm{Vu}$ et al., 2015). In the present experiments, over $95 \%$ of $\mathrm{N}_{2} \mathrm{O}$ emissions were observed after the thermophilic phase for all treatments. Postponing the addition of N-rich substrate increases the accessibility of inorganic $\mathrm{N}\left(\mathrm{NH}_{4}{ }^{+}\right.$and $\left.\mathrm{NO}_{3}{ }^{-}\right)$for nitrifying and denitrifying bacteria and consequently increases $\mathrm{N}_{2} \mathrm{O}$ production. The cumulative $\mathrm{N}_{2} \mathrm{O}$ emissions were higher than those in previous reports on composting (Chowdhury et al., 2014; $\mathrm{Vu}$ et al., 2015). High $\mathrm{NH}_{4}{ }^{+}$and $\mathrm{NO}_{3}{ }^{-}$concentrations in poultry manure may explain the high $\mathrm{N}_{2} \mathrm{O}$ emissions in this experiment.

Early additions of N-rich substrate (i.e. 100/0 and 80/20 treatments) increased the cumulative $\mathrm{CH}_{4}$ emissions from composting, as hypothesised, and the effect was more pronounced with the substrates containing sawdust. The high $\mathrm{CH}_{4}$ production during 
early additions of the N-rich substrate could be explained by (i) the high load of materials which results in more anaerobic pockets in the pile, (ii) the presence of high temperatures in conjunction with high available $\mathrm{C}$ and $\mathrm{N}$ for the methanogens which increases $\mathrm{CH}_{4}$ production, and (iii) low methane oxidation due to the similarity between enzymes involved in methane and ammonium oxidation (Wei et al., 2016). Methanotrophs can switch substrates from $\mathrm{CH}_{4}$ to $\mathrm{NH}_{4}{ }^{+}$and result in low $\mathrm{CH}_{4}$ oxidation. Regardless of the bulking agent used, cumulative $\mathrm{CH}_{4}$ emissions were lower during single addition of the $\mathrm{N}$-rich substrate than when $80 \%$ of the $\mathrm{N}$-rich substrate was added at the beginning of composting (Fig. 4.3). This observation is attributed to the high $\mathrm{NH}_{4}{ }^{+}$ concentration and ammonia volatilisation during single addition of the $\mathrm{N}$-rich substrate because methanogenic activity decreases as ammonia volatilisation and $\mathrm{NH}_{4}{ }^{+}$ concentration increase (Hao et al., 2005). The present findings are in agreement with the results of previous studies reporting on the response of $\mathrm{CH}_{4}$ production from soil to different nitrogen fertilisers (Wei et al., 2016). To the authors' knowledge, this is the first report on the relationship between split addition of an N-rich substrate and GHG emissions during composting. Further investigations are needed to reveal the mechanisms of how the timing of substrate addition influences the GHG budget. For both greenhouse gases $\left(\mathrm{N}_{2} \mathrm{O}\right.$ and $\left.\mathrm{CH}_{4}\right)$, the cumulative emissions were higher with the substrates containing sawdust than those containing coffee husks. The likely explanation is that the bulkier nature of coffee husks allows more air movement through the compost pile than sawdust does. We used two different scenarios to assess the GHG budget from the treatments. The first scenario excludes $\mathrm{CO}_{2}$ from the total GHG budget because higher $\mathrm{CO}_{2}$ evolution indicates a greater degree of stabilisation of the compost. Moreover, the less stable composts produce more $\mathrm{CO}_{2}$ during soil application (Fig 4.4); hence, the total $\mathrm{CO}_{2}$ emissions would eventually converge to the same value for all composts (Supplementary Fig. 4.2). Under this scenario, the total GHG budget was not affected by the timing of N-rich substrate addition. Early addition of N-rich substrate, however, increased the total GHG budget when $\mathrm{CO}_{2}$ was included in the GHG budget. The obvious explanation is that early addition produce higher $\mathrm{CO}_{2}$ than delay addition (Fig 4.3a), and $\mathrm{CO}_{2}$ contributed over $85 \%$ of the total GHG budget in all treatments.

\section{$\mathrm{CO}_{2}$ evolution and compost stability}

The hypothesis that split application of an N-rich substrate increases $\mathrm{C}$ mineralisation after soil application was confirmed. The $\mathrm{CO}_{2}$ evolution from the composts after soil application correlated with the cumulative $\mathrm{CO}_{2}$ emissions during composting (Fig. 4.3a) and $\mathrm{C}$ loss (Table 4.2). Higher total $\mathrm{C}$ loss and $\mathrm{CO}_{2}$ emissions during composting (Fig. 4.3 and Table 4.2) and the subsequent low $\mathrm{CO}_{2}$ emissions after soil application (Fig. 4.4) indicated that composts produced by early additions were at a more advanced stage of decomposition compared to split addition. An obvious explanation for this is that the 
newly added N-rich substrate had less time to decompose. The $\mathrm{CO}_{2}$ emissions after soil application were higher with substrates containing coffee husks, implying that the amount of the easily degradable compound was higher in coffee husks than in sawdust. The $C$ loss observed in this experiment (Table 4.2) was comparable with previous studies on composting (Dias et al., 2010). The unaccounted for $C$ ranged between $16 \%$ and $26 \%$ (Table 4.2) and indicated $\mathrm{C}$ that was not measured between sampling dates (Vu et al., 2015) and/or C loss via volatile compounds (Chowdhury et al., 2014). The sampling frequency might be too infrequent, so that not all the $\mathrm{CO}_{2}$ emissions were captured, particularly from split addition of the substrate when intensive decomposition occurs in the later stages of composting. The unaccounted for $C$ reported in this experiment is, however, comparable with Chowdhury et al. (2014) and Sommer and Dahl, (1999) who reported unaccounted for $\mathrm{C}$ of between $17 \%$ and $36 \%$.

Postponing the addition of N-rich substrates killed seeds of four different and unrelated weed species, as hypothesised. Temperatures above $50{ }^{\circ} \mathrm{C}$ for a minimum of three days are sufficient to destroy most weed seeds and pathogens (Ryckeboer et al., 2003). The temperatures in all treatments (Fig. 4.1) and even the second thermophilic phase during split addition therefore probably destroyed the weed seeds. The temperature profile suggests that a small amount of $\mathrm{N}$ could be enough to generate the thermophilic phase and kill weed seeds and potentially also human pathogens from composting.

The hypothesis that split application of N-rich substrate produces stable compost was confirmed. Combinations of different indices were used to test compost stability since it is difficult to test stability using a single index (Wichuk and McCartney, 2010). Temperature during the composting process is a simple method for evaluating compost stability. Compost temperatures are affected by aeration, pile size, moisture content, degree of insulation and other parameters. Compost temperatures alone therefore provide misleading evidence about compost stability. $\mathrm{CO}_{2}$ evolution is a more reliable indicator of compost stability (Aslam and Vander-Gheynst, 2008). Less than 30\% mineralisable-C in $70 \mathrm{~d}$ is used as an indication of a stable compost (Bernal et al., 2009), confirming that all of the treatments produced stable compost (Fig. 4.4). Water-dissolved organic carbon $(\mathrm{Cw})<17 \mathrm{~g} \mathrm{~kg}^{-1}$ dry matter (Bernal et al., 2009) and a Cw:total nitrogen ratio $<0.7$ (Santos et al., 2016) are indicators of compost maturity, indicating that all of the treatments produced mature compost (Table 4.3). The decrease in $\mathrm{NH}_{4}{ }^{+}$concentration after composting, $\mathrm{C}: \mathrm{N}$ ratios $<15: 1$ (Table 4.3) and eradication of weed seeds could also be indicators of compost stability and/or maturity. An $\mathrm{NH}_{4}{ }^{+}: \mathrm{NO}_{3}{ }^{-}$ratio below 0.16 is often used to indicate compost maturity (Bernal et al., 2009), but none of the treatments did satisfy this criterion due to the high concentration of $\mathrm{NH}_{4}{ }^{+}$in the poultry manure. The $\mathrm{NH}_{4}{ }^{+} \mathrm{NO}_{3}{ }^{-}$ratio was, however, in the acceptable range (i.e. 0.5 - 3.0) (Bernal et al., 2009). The relative seed germination was $>90 \%$ (Table 4.3 ), confirming that the composts were mature. 


\section{Implications}

Nitrogen loss during composting reduces the agronomic value of compost and contributes to greenhouse gas emissions and unpleasant odours. Different strategies have been identified for reducing $\mathrm{N}$ losses from composting, but existing technologies such as controlling the $\mathrm{pH}$ (Pagans et al., 2006), controlling the aeration rate (Chowdhury et al., 2014) and the use of absorbents (i.e. active carbon, biochar and zeolite) (Kahn et al., 2016; Steiner et al., 2010) are expensive and difficult to scale up to field-scale conditions. The addition of crop residues to adjust the $\mathrm{C}: \mathrm{N}$ ratio is another effective method for reducing $\mathrm{N}$ losses (Dias et al., 2010), but there are competing uses of crop residues for animal feed and fuel in smallholding farming systems in developing countries (Nigussie et al., 2015). It is therefore suggested that split addition of N-rich substrate is a less expensive method than the existing solutions for reducing $\mathrm{N}$ losses from composting, which also produces compost with a high fertilising value. Many smallholder farmers prepare compost by continuously adding organic materials to a compost pile, implying that the present experiment corresponds to the activity of smallholder farmers in developing countries. In practice, however, it is not only nitrogen-rich substrates that are added continuously to a compost pile, but different qualities of materials as well. Further studies, therefore, are needed to determine the effect of split application of different quality substrates on the composting process.

\section{Conclusions}

Irrespective of the bulking agent used, split addition of the nitrogen-rich substrate reduced nitrogen loss without having a significant effect on total greenhouse gas emissions, compost stability and sanitisation. Split addition of the N-rich substrate increased $\mathrm{N}$ mineralisation after soil application, implying an increase in the fertilising value of the end product. This study demonstrated that the timing of substrate addition affected $\mathrm{CH}_{4}$ and $\mathrm{N}_{2} \mathrm{O}$ emissions, but not the total GHG budget. Split addition of N-rich substrates did not affect the temperature profile during the thermophilic phase and was effective at eradicating a wide range of weed seeds. This study provides essential information with regard to the timing of substrate addition to produce compost with a high fertilising value and avoid emissions of greenhouse gases. However, further studies are needed to scale up this technique to field conditions. Experiments in the presence of plants are also recommended in order to test the effect of split addition of an N-rich substrate on the agronomic value of the compost. 


\section{Acknowledgements}

This work has been conducted as part of a $\mathrm{PhD}$ thesis project supported by the Agricultural Transformation by Innovation (AgTraIn) Erasmus Mundus Joint Doctorate Programme, funded by the EACEA (Education, Audio-visual and Culture Executive Agency) of the European Commission. The authors would like to acknowledge the anonymous reviewers for their constructive comments on the earlier version of the manuscript. 


\section{Appendix}
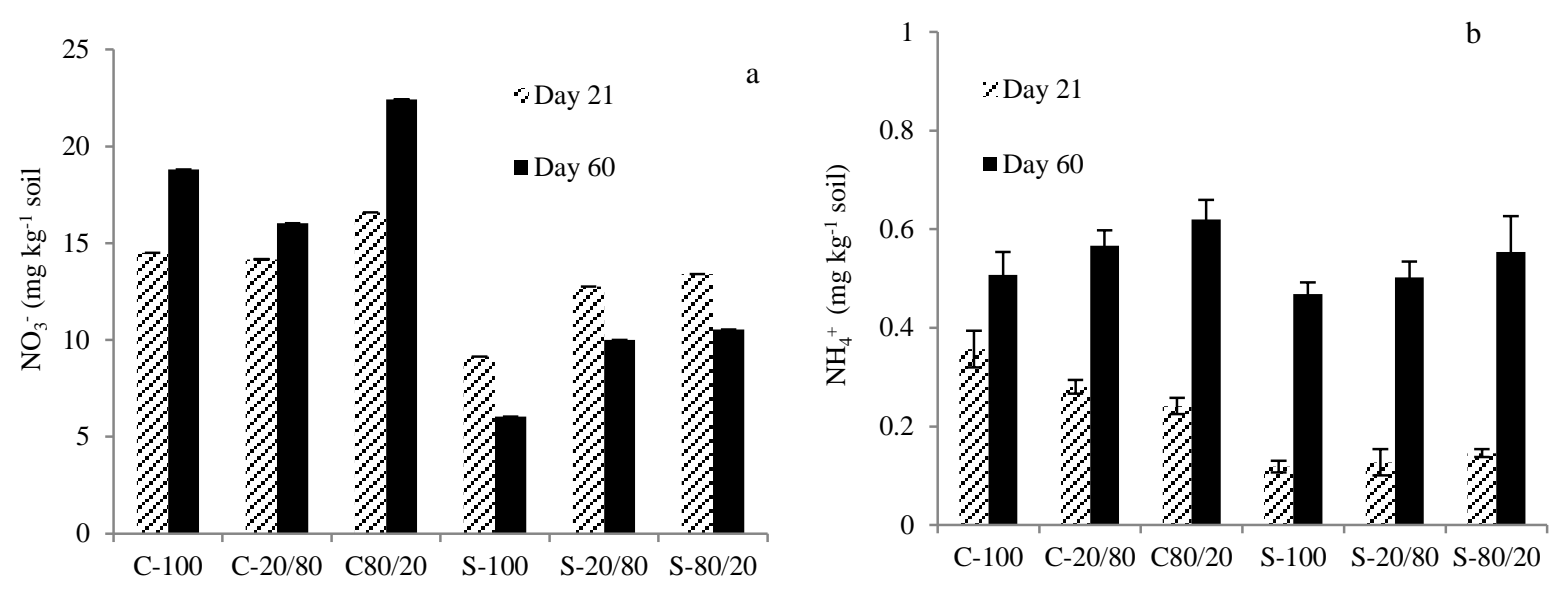

Supplementary Figure 4.1. Inorganic $\mathrm{N}$ content during incubation experiment. (a) $\mathrm{NO}_{3}$-concentration; (b) $\mathrm{NH}_{4}{ }^{+}$concentration; $\mathrm{C}=$ coffee husk, $\mathrm{S}=$ sawdust; $\mathrm{C}-100$ and/or S-100 = all poultry manure was applied at the beginning of composting; C- $80 / 20$ and/or S-80/20 $=80 \%$ of the poultry manure was applied at the beginning of composting and the remaining $20 \%$ was added after the thermophilic phase; C-20/80 and/or S-20/80 $=20 \%$ of the poultry manure was applied at the beginning of composting and the remaining $80 \%$ as added after the thermophilic phase.

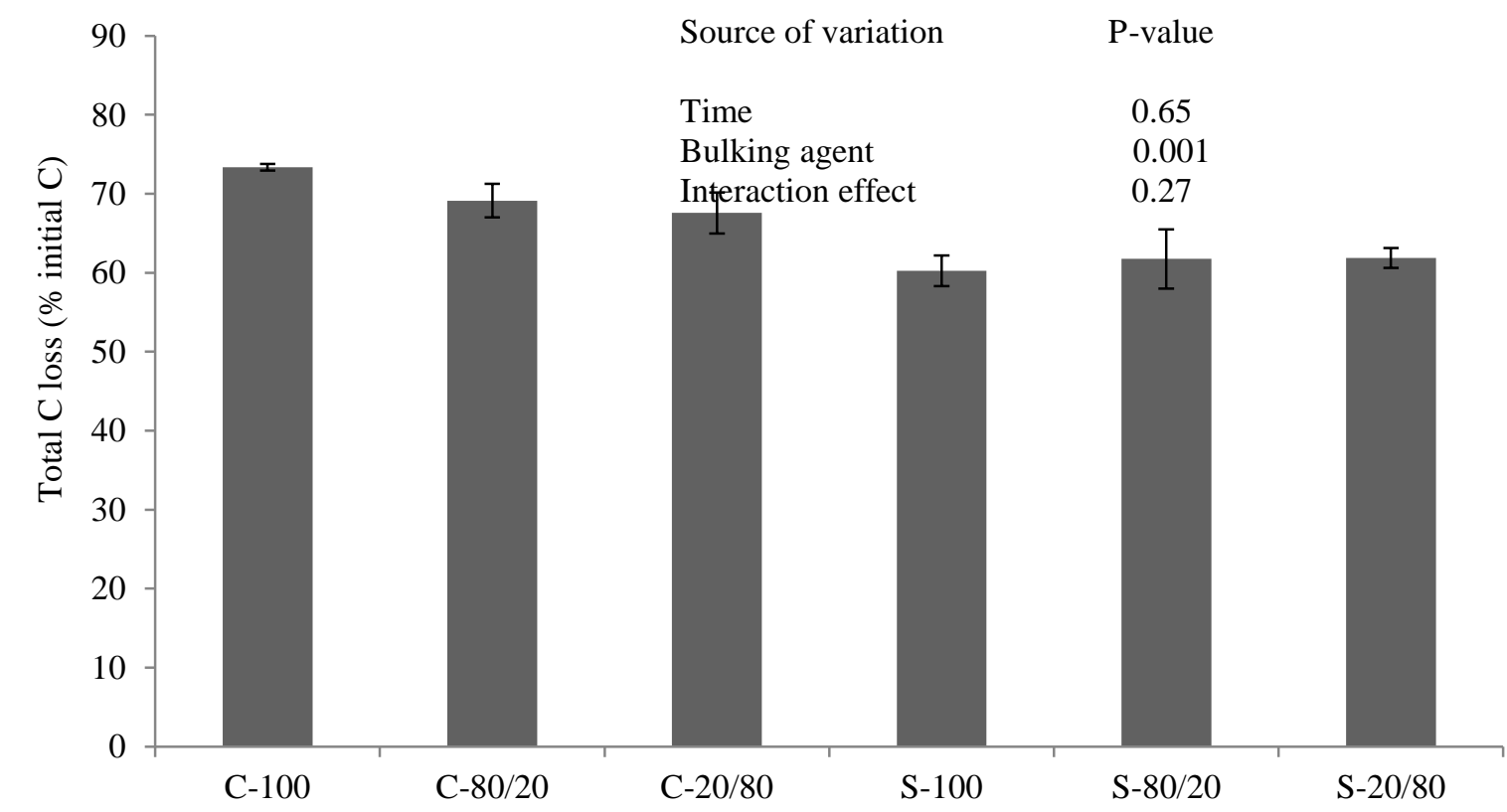

Supplementary Figure 4.2. The total $\mathrm{C}$ loss after the composting and soil incubation phases. $\mathrm{C}=$ coffee husk, $\mathrm{S}=$ sawdust; $\mathrm{C}-100$ and/or $\mathrm{S}-100=$ all poultry manure was applied at the beginning of composting; C-80/20 and/or S- $80 / 20=80 \%$ of the poultry manure was applied at the beginning of composting and the remaining $20 \%$ was added after the thermophilic phase; C-20/80 and/or S-20/80 = $20 \%$ of the poultry manure was applied at the beginning of composting and the remaining $80 \%$ as added after the thermophilic phase. 


\section{CHAPTER 5}

\section{Earthworms change the quantity and composition of dissolved organic carbon and reduce greenhouse gas emissions during composting}

Submitted to Waste Management as:

Nigussie, A., Bruun, S., de Neergaard, A., Kuyper, TW. Earthworms change the quantity and composition of dissolved organic carbon and reduce greenhouse gas emissions during composting 


\title{
Earthworms change the quantity and composition of dissolved organic carbon and reduce greenhouse gas emissions during composting
}

\begin{abstract}
Vermicomposting has been suggested as an alternative composting method that is efficient at stabilising biodegradable waste and reducing greenhouse gas emissions during composting. The amount of substrate added per earthworm biomass (i.e. feeding ratio) influences the growth and activity of earthworms and aeration. However, the effect of earthworms and feeding ratio on the stabilisation process is not known. Dissolved organic carbon (DOC) has recently been proposed as an indicator of compost stability. The objective of this study was therefore to assess the earthworms' effect on DOC content (quantity) and composition (quality), and on greenhouse gas emissions; and link this effect to feeding ratio and substrate quality. The results showed that earthworms reduced total DOC content and $\mathrm{NH}_{4}{ }^{+}$: $\mathrm{NO}_{3}{ }^{-}$ratio, indicating larger stability of earthworm compost. The concentrations of humic acid and fulvic acid were also reduced by earthworms, whereas there was no significant effect on hydrophobic neutrals and hydrophilics. The humic acid fraction was depleted more quickly than the other compounds, indicating that humic acids are degraded during composting. The optimum feeding ratio decreased DOC content, humic acid and fulvic acid, but increased cumulative $\mathrm{CO}_{2}$ production compared with the high ratio. The lowest cumulative $\mathrm{N}_{2} \mathrm{O}$ emissions were observed at the optimum feeding ratio; there was no significant difference between the high feeding ratio and non-earthworm treatments. These results suggest that measurement of DOC components provides greater insight into the stabilisation process. Moreover, feeding ratio should be considered as an essential parameter when assessing the effect of earthworms on organic-waste stabilisation and greenhouse gas emissions.
\end{abstract}

Keywords: vermicomposting, nitrous oxide, feeding ratio, dissolved organic carbon, stabilisation 


\section{Introduction}

Thermophilic composting and vermicomposting are two composting techniques commonly used to convert biodegradable waste into compost. Thermophilic composting is a microbially-mediated, high-temperature $\left(>45^{\circ} \mathrm{C}\right)$ process, while vermicomposting is a mesophilic $\left(<30^{\circ} \mathrm{C}\right)$ process that involves earthworms and associated microorganisms in the decomposition and stabilisation of organic materials (Munroe, 2007). The temperature during vermicomposting should remain within the range of $15-30{ }^{\circ} \mathrm{C}$, as temperatures above $35{ }^{\circ} \mathrm{C}$ kill earthworms (Munroe, 2007). The temperatures are kept low in vermicomposting by gradual addition of the substrate (Nigussie et al., 2016) and/or pre-composting the material prior to vermicomposting (Lazcano et al., 2008).

Considerable decomposition while retaining higher nutrient concentrations was observed during vermicomposting compared with thermophilic composting (Nigussie et al., 2016a; Lazcano et al., 2008). In contrast, high $\mathrm{N}$ losses occur during thermophilic composting because high temperatures $\left(>45^{\circ} \mathrm{C}\right)$ increase ammonia volatilisation (Pagans et al., 2006). Temperatures above $45^{\circ} \mathrm{C}$ are however considered essential for eradicating seeds and pathogens from compost (Ryckeboer et al., 2003). Vermicomposting has also been shown to be effective at eradicating weeds and pathogens (Edwards et al., 2011), but the mechanisms of how earthworms kill weed seeds and pathogens is not known and the reports are contradictory. Hence the combination of thermophilic composting and vermicomposting has most often been proposed to produce compost of high agronomic value that is at the same time pathogen-free (Lazcano et al., 2008). The first phase - thermophilic composting - occurs only for a short period of time, mainly to eradicate pathogens and eliminate toxic compounds, and the subsequent vermicomposting (i.e. the second phase) is carried out to accelerate the stabilisation process and improve the agronomic value of compost (Lazcano et al., 2008).

It is important that compost should be sufficiently stable prior to soil application because unstable compost reduces plant growth. Unstable compost leads to oxygen depletion in the root zone and osmotic stress and contains phytotoxic compounds (Wichuk and McCartney, 2010). Compost is considered stable when the organic matter decomposition rate is reduced to a low level with no heat development. A number of indices are used to determine compost stability (Bernal et al., 2009; Khan et al., 2014). Evolution of $\mathrm{CO}_{2}$ is the most commonly used indicator (Bernal et al., 2009; Nigussie et al., $2016 \mathrm{~b})$, but this index is influenced by a number of factors such as substrate quality. Lack of heat development is another simple method for evaluating compost stability (BoulterBitzer et al., 2006), however it is also affected by aeration, pile size, moisture content, degree of insulation and other parameters. Therefore the use of one index to determine compost stability is potentially misleading. Indices such as a C: $\mathrm{N}$ ratio $<12$ and a $\mathrm{NH}_{4}{ }^{+}-$ $\mathrm{N}: \mathrm{NO}_{3}-\mathrm{N}$ ratio $<0.16$ are also recommended as a threshold level for indicating compost maturity (Khan et al., 2014), however, theses indices also depend on substrate quality. 
Numerous researchers have therefore suggested the combined use of multiple indices as indicator for compost stability (Bernal et al., 2009; Khan et al., 2014).

Dissolved organic carbon (DOC) has recently been proposed as an indicator of compost stability (Bernal et al., 2009; Santos et al., 2016). A maximum threshold DOC value of $4 \mathrm{~g} \mathrm{~kg}^{-1}$ dry matter is used as an indicator of stable compost (Zmora-Nahum et al., 2005; Kahn et al., 2014). Not only the quantity but also the quality (i.e. chemical composition) of DOC can be used to assess compost stability. A batch fractionation procedure (Van Zomeren and Comans, 2007) is currently used to separate DOC into four fractions, viz., humic acid (HA), fulvic acid (FA), hydrophobic neutral (HON), all considered as hydrophobic compounds, and hydrophilic (Hi) compounds (Straathof and Comans, 2015). A recent study has shown that the proportions of these four fractions vary between composts, irrespective of DOC concentration (Straathof and Comans, 2015). Hi compounds declined during composting likely because they were used as a substrate for microorganisms, and the hydrophobic compounds (HA, FA and HON) fractionally increased in stable compost.

It is plausible that earthworms influence the DOC quantity and quality (composition) of compost because they ingest the substrates and thereby condition the microbial communities that influence the decomposition process. Previous studies have found higher stabilisation of compost as a result of vermicomposting compared to thermophilic composting using indices such as $\mathrm{CO}_{2}$ evolution (Nigussie et al., 2016; Ngo et al., 2013) and biochemical analysis (Lazcano et al., 2008). However, little is known about the effect of earthworms on DOC quantity and quality during vermicomposting.

Feeding ratio is defined as the amount of substrate added per weight of earthworm (Ndegwa et al., 2000) and high feeding ratio decreases the conversion rate of fresh materials into vermicompost. Previous studies have shown that very high food supply reduces the biomass and reproduction of earthworms (Luth et al., 2011). Furthermore, Ndegwa et al. (2000) found that low feeding ratio increases the mineralisation of nutrients (particularly nitrogen) compared with high feeding ratio. High feeding ratio increases temperature and impedes air circulation in the pile (Luth et al., 2011), both of which affect GHG emissions. For instance, if food supply is too high (supra-optimal feeding ratio) per unit earthworm biomass, the temperature in the pile increases; high temperatures and anoxic patches not only result in increased earthworm mortality, but in greater GHG emissions as well. Feeding ratio is therefore an essential parameter that should be considered when assessing the effect of earthworms on stabilisation and greenhouse gas emissions. Recent reports have used substrate quality (Nigussie et al., 2016; Wang et al., 2015) and earthworm density (Nigussie et al., 2016) to evaluate the effect of earthworms on decomposition and GHG emissions. In addition, feed type affects the conversion rate of fresh materials into vermicompost (Edwards and Bohlen, 1996). However, the effect of feeding ratio on stabilisation processes and GHG emissions during vermicomposting is not known. The objectives of the present study 
were therefore (i) to evaluate the effect of earthworms on DOC quantity and composition of the compost, linking this effect to the initial substrate quality and feeding ratio, and (ii) to assess the effect of feeding ratio on GHG emissions from vermicomposting. We hypothesised that (i) earthworms reduce the DOC content of compost compared to nonearthworm composting, with the effect of earthworms being greater at the optimal feeding ratio; (ii) earthworms reduce DOC content more in substrates that underwent the shortest pre-composting period, (iii) earthworms reduce the fractional contribution of $\mathrm{Hi}$ and hence increase the fractional contribution made by HA, FA and HON compared to non-earthworm composting, (iv) high feeding ratio increases GHG emissions from vermicomposting compared to the optimal feeding ratio, and (v) high feeding ratio reduces compost stability, as assessed by $\mathrm{CO}_{2}$ fluxes, compared to the optimal feeding ratio.

\section{Materials and Methods}

\section{Experimental setup}

Pre-decomposed garden waste was obtained from Unifarm, part of Wageningen University and Research, and placed in plastic boxes $(30 \mathrm{~cm}$ width X $40 \mathrm{~cm}$ length X 25 $\mathrm{cm}$ height). Three substrates with different composition that have undergone different degrees of decomposition were used as composting materials. The first substrate (substrate_1) had been through the composting process for three months and the second substrate (substrate_2) had been through the composting process for nearly $1 \frac{1 / 2}{2}$ months. The third substrate (substrate_3) was prepared from substrate_1, substrate_2 and cattle manure at a ratio of 1:1:1. The cattle manure was added in the third substrate to increase nitrogen availability in the mixture, whereas pre-decomposed materials were used in this experiment to avoid the development of high temperatures in the vermicompost bins. Hence there was no temperature effect in our experiment unlike the previous composting experiments (Nigussie et al., 2016; Straathof and Comans, 2015).

Mixtures of adult individuals of two epigeic earthworm species, namely Eisenia fetida and Dendrobaena veneta (approximate 2:1 ratio), were obtained from two earthworm breeding companies, 'De Polderworm' and Star Foods, in The Netherlands. The earthworms were added at a stocking density of $3 \mathrm{~kg}$ earthworms $\mathrm{m}^{-2}$. The substrates were added to the vermicomposting bin in two doses: (i) $1.5 \mathrm{~kg}$ substrate kg earthworms${ }^{1}$ (recommended by Aira and Domínguez, 2008) - hereafter referred to as optimal ratio (OR) - and (ii) $3 \mathrm{~kg}$ substrate $\mathrm{kg}$ earthworms ${ }^{-1}$ - hereafter referred to as the high ratio (HR). Treatments without earthworms were used as controls. The experiment had two factors arranged in a $3 \times 3$ (earthworm treatments (OR, HR and control) $X$ substrate quality) complete randomised design with three replicates. The experiment was conducted for 60 days, and the moisture content in each container was adjusted to 70$75 \%$ by spraying of water on top. 


\section{DOC and its fractionation}

DOC was extracted using ultra-pure water, as described by Straathof and Comans (2015). Briefly, fresh compost was mixed with ultra-pure milli-Q water at a 1:10 ratio (w/v), shaken for one hour on a horizontal shaker and filtered through a $0.45 \mu \mathrm{m}$ filter (Whatman TM). Due to the heterogeneity of the compost samples, each sample was replicated four times and the replicates were finally pooled together after the extracts had been filtered. A sub-sample $(5 \mathrm{ml})$ was then taken and analysed for DOC concentration using San ${ }^{++}$channel SFA (SKALAR, The Netherlands). The remaining samples were used for DOC fractionation.

The batch fractionation procedure (Van Zomeren and Comans, 2007) was used to separate the DOC fractions. Briefly, $40 \mathrm{ml}$ of the DOC sample was added in a $50 \mathrm{ml}$ centrifuge tube, acidified to $\mathrm{pH} 1.0$ with $6 \mathrm{M} \mathrm{HCl}$ and allowed to stand overnight. This step allowed the humic acid (HA) fraction to precipitate and form pellets. The acidified solution was then centrifuged (20 min, $3500 \mathrm{~g}$ ) to separate the HA (i.e. the pellets) from the supernatant containing FA, HON and $\mathrm{Hi}(\mathrm{FaHyHON})$. About $25 \mathrm{ml}$ of $0.1 \mathrm{M} \mathrm{KOH}$ ( $\mathrm{pH}$ 12.0) was added to the pellets and shaken for $20 \mathrm{~min}$ to re-suspend the HA fraction. The supernatant was transferred to another $50 \mathrm{ml}$ centrifuge tube. About $15 \mathrm{ml}$ of the supernatant was added to a 3 gm DAX-8 resin (Sigma-Aldrich), shaken for one hour and filtered through $0.45 \mu \mathrm{m}$ (Whatman TM). This step separated the hydrophilic compounds (Hi) from the supernatant. Finally, $15 \mathrm{ml} 0.1 \mathrm{M} \mathrm{KOH}$ was added to the DAX8 resin, shaken for one hour, and filtered through $0.45 \mu \mathrm{m}$ (Whatman TM) to separate the fulvic acid (FA) fractions. This step was repeated three or more times until the concentration in the samples was equal to the blank samples. The neutral (HoN) fractions were estimated from the DOC that was not dissolved under alkaline conditions. The concentrations of each fraction were measured using San ${ }^{++}$channel SFA (SKALAR, The Netherlands).

\section{Gas sampling}

The static chamber method was used to collect gas samples (Chan et al., 2010) every two days for the first week and then once a week until the end of the experiment, after 60 days. Gas samples were collected three times after closing the chamber $(0,20$ and 40 minutes). Gas samples were also collected after 0, 20, 40, 60, 80 and 100 minutes every month in order to check the linearity assumption. The gas samples were measured using INNOVA 1412 photoacoustic field gas monitor (LumaSense Technologies, Ballerup, Denmark). The emissions rate in $\mathrm{mg} \mathrm{kg}^{-1}$ initial dry matter day-1 was calculated as: 


$$
\text { Emission rate }=\left(\frac{\Delta \mathrm{C}}{\Delta \mathrm{t}}\right) *\left(\frac{\mathrm{V}}{\mathrm{W}}\right) *\left(\frac{\mathrm{M}}{\mathrm{Vs}}\right) *\left(\frac{\mathrm{P}}{\mathrm{Po}}\right) *\left(\frac{273}{\mathrm{~T}}\right)
$$

where $\Delta \mathrm{C}$ is the change in concentration of gas (ppm) during time interval $\Delta \mathrm{t}$ in days, $\mathrm{V}$ is the headspace volume (litres), $\mathrm{M}$ is the molecular mass of the gas of interest (44,16 and $44 \mathrm{~g}$ for $\mathrm{CO}_{2}, \mathrm{CH}_{4}$ and $\mathrm{N}_{2} \mathrm{O}$ respectively), $\mathrm{Vs}$ is the volume occupied by 1 mole of a gas at standard temperature and pressure (22.4 litre), $\mathrm{P}$ is the atmospheric pressure (bar), Po is the standard pressure (1.013 bar), $\mathrm{T}$ is the temperature inside the chamber during the deployment time in Kelvin, and $\mathrm{W}$ is the initial dry mass of the composting material $(\mathrm{kg})$.

The cumulative emissions were calculated using the trapezoid integration rule (Ly et al., 2013).

\section{Chemical analyses}

Compost samples were collected at the end of the experiment for the analyses of $\mathrm{pH}$, $\mathrm{NO}_{3}{ }^{-}$and $\mathrm{NH}_{4}{ }^{+}$. The samples were stored at $4{ }^{\circ} \mathrm{C}$ prior to laboratory analysis. $\mathrm{pH}$ was measured from a compost : water ratio of $1: 10(\mathrm{w} / \mathrm{v})$, whereas $\mathrm{NO}_{3}-$ and $\mathrm{NH}_{4}{ }^{+}$ concentrations were determined using $1 \mathrm{M} \mathrm{KCl}$. The compost samples were mixed with 1 $\mathrm{M} \mathrm{KCl}$ at a ratio of 1:100 compost:solution (w/v) and shaken for one hour. The extracts were then analysed for $\mathrm{NH}_{4}{ }^{+}$and $\mathrm{NO}_{3}{ }^{-}$concentrations using segmented flow analysis (SFA) (SKALAR analytical, Netherlands).

\section{Statistical analyses}

A two-way analysis of variance (ANOVA) was performed to test for significant effects of earthworm treatments, substrate quality and their interactions. A separate ANOVA was performed - excluding the control treatment - to test for significant effects of two feeding ratios on the vermicomposting process. The data were checked for the assumptions of ANOVA prior to data analysis. Levene and Shapiro-Wilk's tests were used to test for homogeneity of variance and normality respectively. Data on the change in earthworm biomass did not fit with ANOVA assumptions and hence the data were log-transformed. Tukey test was used to compare the means if the factors' effect was found significant at $P$ $<0.05$. Linear regression was performed between the $\mathrm{CO}_{2}$ emissions in the last week as an independent variable and DOC quantity and DOC composition as a dependent variable. All statistical analyses were undertaken using SAS version 9.2. 


\section{Results}

\section{DOC quantity and composition}

The effects of earthworms on DOC concentration are presented in Figure 5.1. There was a significant effect of earthworm treatment $(\mathrm{P}<0.001)$ and substrate quality $(\mathrm{P}<0.001)$ on DOC concentration as well as a significant interaction between them $(P=0.001)$. The presence of earthworms reduced DOC concentration by $7-28 \%$, depending on substrate quality and feeding ratio. The DOC concentration per total $\mathrm{C}$ mineralised was calculated, and earthworms decreased the total DOC concentration by $38-60 \%$ compared with the non-earthworm treatments. The effect of earthworms on DOC was observed more in substrate_3. DOC contents were lower than $4 \mathrm{~g} \mathrm{~kg}^{-1}$ dry matter with substrate one, around $4 \mathrm{~g} \mathrm{~kg}^{-1}$ dry matter with substrate_2 and higher than the critical limit value of $4 \mathrm{~g}$ $\mathrm{kg}^{-1}$ dry matter for substrate_3, indicating decreasing stability of the final product. The optimal feeding ratio significantly $(P<0.01)$ decreased DOC concentration compared with the higher ratio.

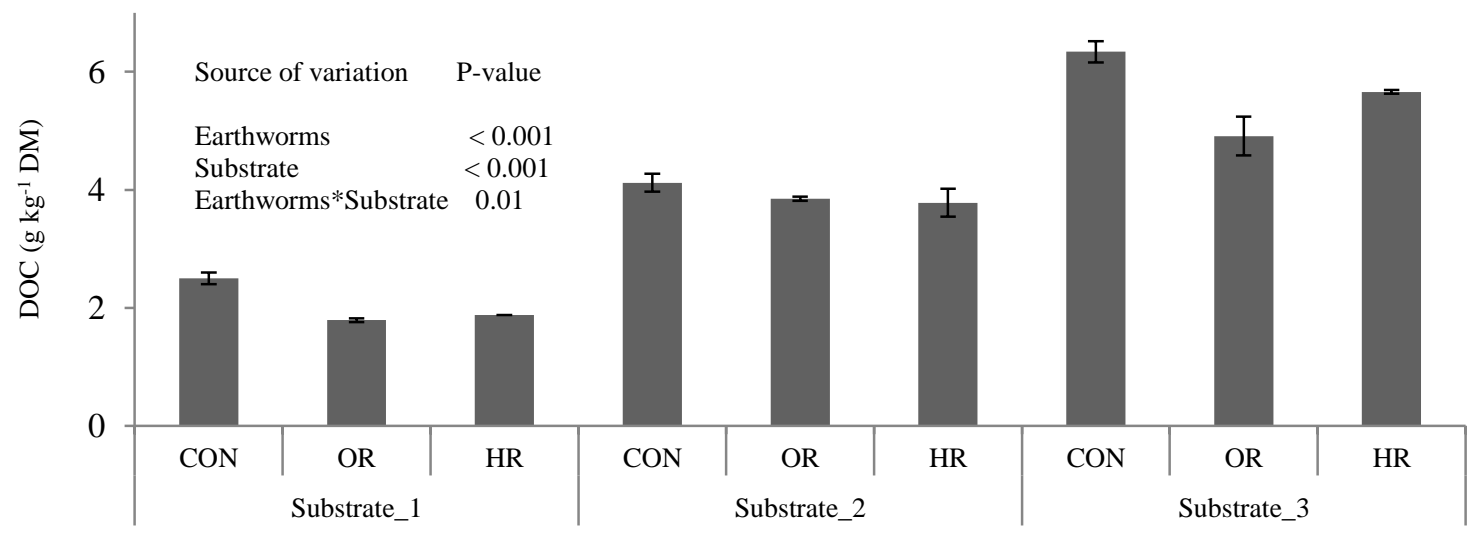

Figure 5.1. Total DOC concentration of the composts after 60 days of composting (mean \pm standard error of the mean; $\mathrm{n}=3$ ). $\mathrm{CON}=$ without earthworms, $\mathrm{OR}=$ optimal substrate-to-earthworm ratio, $\mathrm{HR}$ = higher substrate-to-earthworm, $\mathrm{DM}=$ dry matter

The percentage of DOC retrieved throughout the fractionation procedure was $85-98 \%$, which was comparable with the previous study on compost (Straathof and Comans, 2015). Concentrations of hydrophilic and hydrophobic (HA, FA, HON) fractions of DOC also varied between treatments and there was a significant earthworm * substrate interaction (Table 5.1). FA was the dominant proportion of DOC ( $>45 \%$ ) while HON contributed the lowest proportion $(<14 \%)$, irrespective of the treatments. Analysis of variance showed that the concentrations of HA, FA, HON and Hi were affected by substrate quality $(\mathrm{P}=0.001, \mathrm{P}=0.001, \mathrm{P}<0.001$ and $\mathrm{P}<0.001$ respectively), but the presence of earthworms only had a significant effect on HA and FA $(\mathrm{P}=0.001$ and $\mathrm{P}=$ 0.001 respectively). Substrates that underwent the longest pre-composting period (i.e. 
substrate_1) had the lowest concentrations of HA, FA, HON and Hi. The relative proportions of each fraction to total DOC are presented in Supplementary Figure 5.1. The presence of earthworms decreased the relative proportion of HA to total DOC $(P=0.02)$, but the relative proportions of FA, HON and $\mathrm{Hi}$ were not significantly affected by the earthworms. Similarly, feeding ratio did not affect the proportion of each fraction to total DOC. Linear regression between the last week of $\mathrm{CO}_{2}$ evolution and the concentration of DOC and its different fractions (Fig. 5.2) showed a positive and significant relationship for all components ( $\mathrm{P}<0.001$ in all cases). The stability of the various compounds, as judged from the slope for the various compounds, was different. With a $50 \%$ reduction of the final $\mathrm{CO}_{2}$ flux, HA was most reduced (to 40\%), followed by DOC, FA and Hy (51$53 \%$ ), while $\mathrm{HON}$ was most stable (reduced to $59 \%$ ).

Table 5.1. Absolute concentration (mean \pm SEM) of the different DOC fractions after $60 \mathrm{~d}$ of composting

\begin{tabular}{|c|c|c|c|c|c|}
\hline \multirow[t]{2}{*}{ Substrate } & & \multicolumn{4}{|c|}{ DOC fractions ( $\left.\mathrm{g} \mathrm{Kg}^{-1} \mathrm{DM}\right)$} \\
\hline & & HA & FA & $\mathrm{HON}$ & $\mathrm{Hi}$ \\
\hline \multirow[t]{3}{*}{ Substrate_1 } & $\mathrm{CON}$ & $0.34+0.07$ & $1.13 \pm 0.10$ & $0.37 \pm 0.03$ & $0.38 \pm 0.03$ \\
\hline & OR & $0.20 \pm 0.10$ & $0.90 \pm 0.10$ & $0.23 \pm 0.12$ & $0.32 \pm 0.01$ \\
\hline & HR & $0.22+0.02$ & $0.94 \pm 0.17$ & $0.22 \pm 0.18$ & $0.31 \pm 0.01$ \\
\hline \multirow[t]{3}{*}{ Substrate_2 } & $\mathrm{CON}$ & $0.61 \pm 0.06$ & $2.02 \pm 0.09$ & $0.41 \pm 0.04$ & $0.80 \pm 0.07$ \\
\hline & OR & $0.53+0.09$ & $1.75 \pm 0.01$ & $0.56 \pm 0.04$ & $0.67 \pm 0.03$ \\
\hline & HR & $0.52+0.11$ & $1.61 \pm 0.01$ & $0.60 \pm 0.12$ & $0.78 \pm 0.04$ \\
\hline \multirow[t]{3}{*}{ Substrate_3 } & $\mathrm{CON}$ & $1.15 \pm 0.07$ & $2.97 \pm 0.23$ & $0.62 \pm 0.01$ & $0.99+0.10$ \\
\hline & OR & $0.57 \pm 0.10$ & $2.79 \pm 0.27$ & $0.52 \pm 0.06$ & $0.95 \pm 0.08$ \\
\hline & HR & $0.82 \pm 0.06$ & $2.76 \pm 0.11$ & $0.62 \pm 0.05$ & $1.06 \pm 0.04$ \\
\hline \multicolumn{6}{|l|}{ ANOVA } \\
\hline Earthworm (E) & & $<0.001$ & $<0.001$ & 0.42 & 0.49 \\
\hline Substrate (S) & & $<0.001$ & $<0.001$ & $<0.001$ & $<0.001$ \\
\hline Earthworm * Substrate & & 0.007 & 0.18 & 0.01 & 0.03 \\
\hline
\end{tabular}



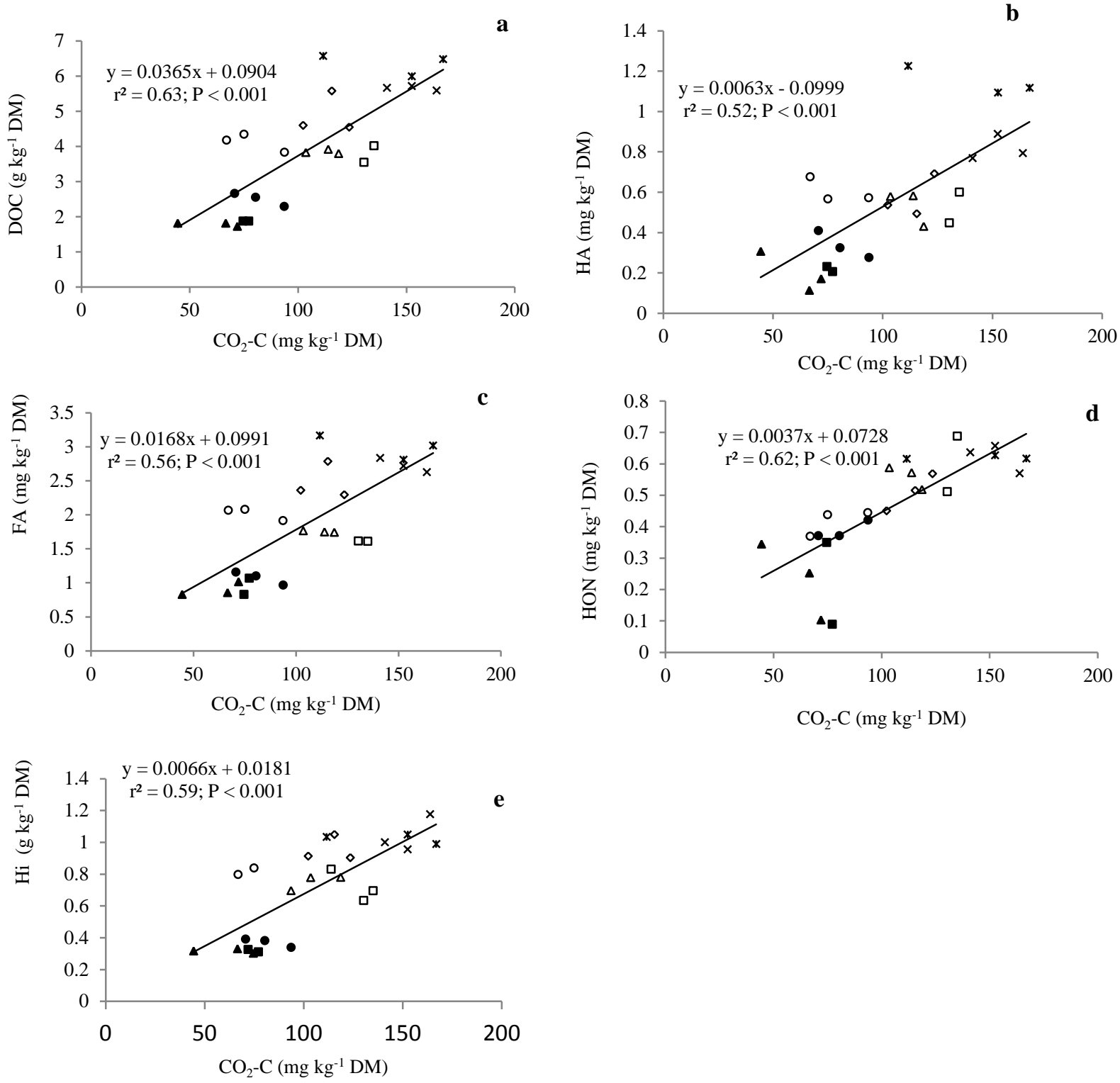

Figure 5.2. Linear regression between $\mathrm{CO}_{2}-\mathrm{C}$ emissions at the end of experiment and different dissolved organic carbon pools at the end of experiment: (a) total DOC, (B) humic acid, (c) fulvic acid, (d) hydrophobic neutral, (e) hydrophilic compounds. DM = dry matter. $\bullet, \mathbf{\Lambda}, \mathbf{\square}$ represent CON, OR and HR of substrate_1 respectively, $\circ, \Delta, \square$ represent CON, OR and HR of substrate_2, $\diamond, x, *$ represent CON, OR and HR of substrate_3 respectively.

\section{GHG emissions}

The earthworm treatments and substrate quality influenced GHG emissions during composting (Fig. 5.3). Total cumulative $\mathrm{CO}_{2}$ emissions differed between the earthworm treatments $(\mathrm{P}<0.001)$ and substrate quality $(\mathrm{P}<0.001)$. There was also an interaction between the two factors $(\mathrm{P}<0.001)$. The presence of earthworms increased $\mathrm{CO}_{2}$ production mainly from substrate_2 and substrate_3. Similarly, the optimal feeding ratio increased $\mathrm{CO}_{2}$ emissions from vermicomposting compared with the higher ratio $(\mathrm{P}<$ 
0.001). $\mathrm{N}_{2} \mathrm{O}$ emissions were affected by the earthworm treatments $(P=0.001)$ and substrate quality $(\mathrm{P}<0.001)$. The high feeding ratio increased cumulative $\mathrm{N}_{2} \mathrm{O}$ emissions compared with the optimal ratio $(\mathrm{P}<0.001)$, but no difference was observed between high feeding ratio and composting without worms. $\mathrm{CH}_{4}$ production was very small in all treatments, and its contribution to the GHG budget was negligible and there was no significant effect of the treatments. When $\mathrm{CO}_{2}$ was excluded from the total GHG emissions, the optimum feeding ratio decreased total GHG emissions compared to the high feeding ratio and non-earthworm treatment. However, both earthworm treatments had a higher total GHG budget than non-earthworm treatments $(\mathrm{P}<0.001)$ when $\mathrm{CO}_{2}$ was accounted for in the total GHG budget. Similarly, the optimum feeding ratio had higher total GHG emissions than the high feeding ratio $(\mathrm{P}<0.001)$ when $\mathrm{CO}_{2}$ was accounted for in the total GHG budget.
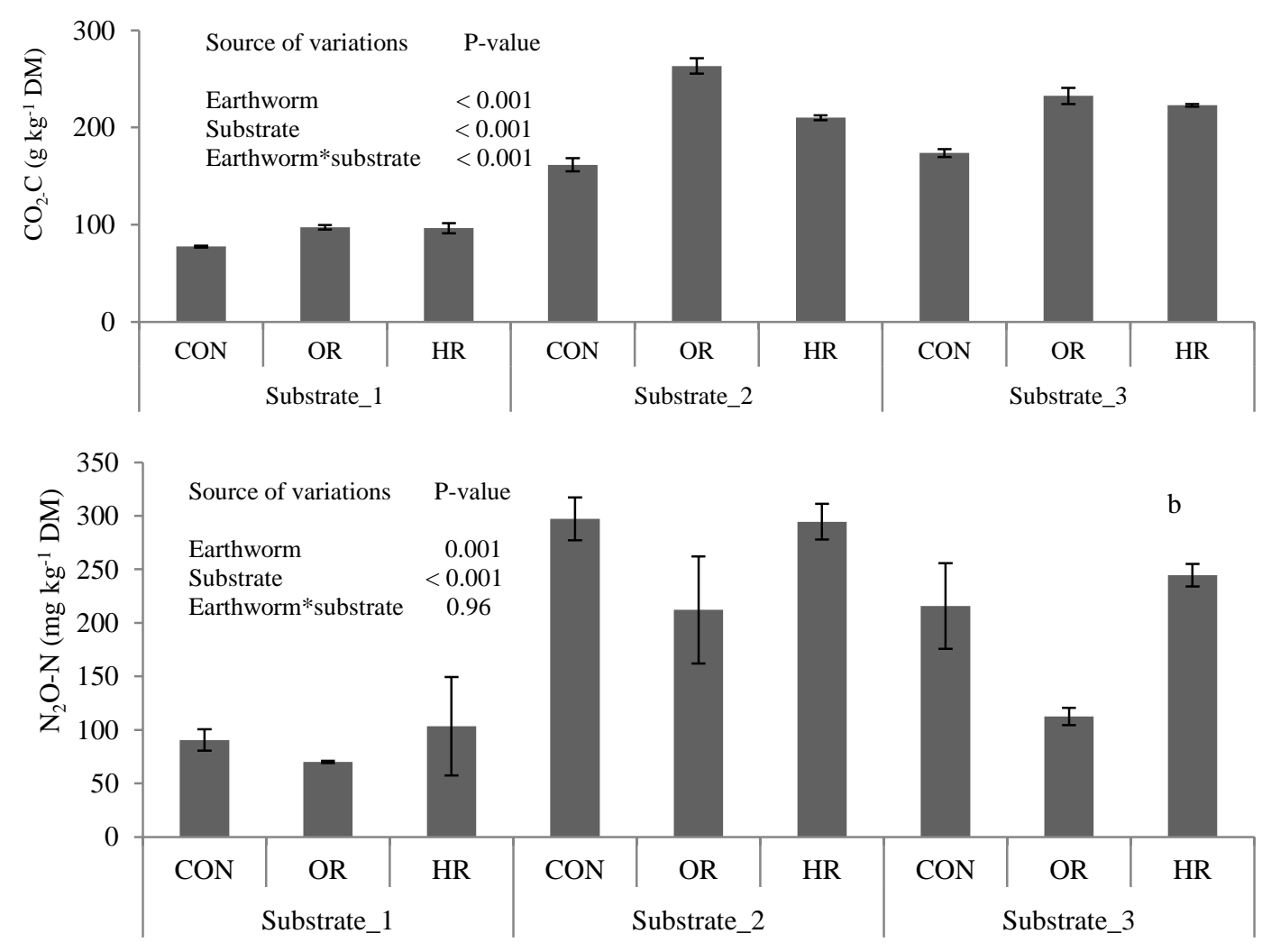

Figure 5.3. Total cumulative GHG emissions after 60 days of composting: (a) $\mathrm{CO}_{2}$ emissions, (b) $\mathrm{N}_{2} \mathrm{O}$ emissions. $\mathrm{CON}=$ without earthworms, $\mathrm{OR}=$ optimal earthworm-to-substrate ratio, $\mathrm{HR}=$ higher earthworm-to-substrate ratio

\section{Chemical properties}

The $\mathrm{NO}_{3}$ - concentration differed between the earthworm treatments $(\mathrm{P}<0.001)$, substrate quality $(\mathrm{P}<0.001)$ and there was also interaction $(\mathrm{P}=0.02)$ (Fig 5.4). The presence of earthworms increased $\mathrm{NO}_{3}$ - concentration by up to $400 \%$ compared with the nonearthworm treatments. $\mathrm{NH}_{4}{ }^{+}$concentration was not, however, affected by the earthworm 
treatments $(\mathrm{P}=0.49)$, substrate quality $(\mathrm{P}=0.51)$ and there was no interaction effect $(\mathrm{P}=$ 0.71). The $\mathrm{NH}_{4}{ }^{+}: \mathrm{NO}_{3}$ ratio varied between the earthworm treatments $(\mathrm{P}<0.001)$, substrate quality $(P=0.02)$ and there was also interaction $(P=0.03)$. The earthworm treatments reduced the $\mathrm{NH}_{4}^{+}: \mathrm{NO}_{3}^{-}$ratio by up to $50-80 \%$. The $\mathrm{pH}$ was affected by the earthworm treatments $(\mathrm{P}<0.001)$ and substrate $(\mathrm{P}=0.01)$. The presence of earthworms reduced $\mathrm{pH}$ compared with non-earthworm treatments, irrespective of the substrate quality. The optimal feeding ratio resulted in lower $\mathrm{pH}$ compared to the high feeding ratio $(\mathrm{P}<0.01)$.
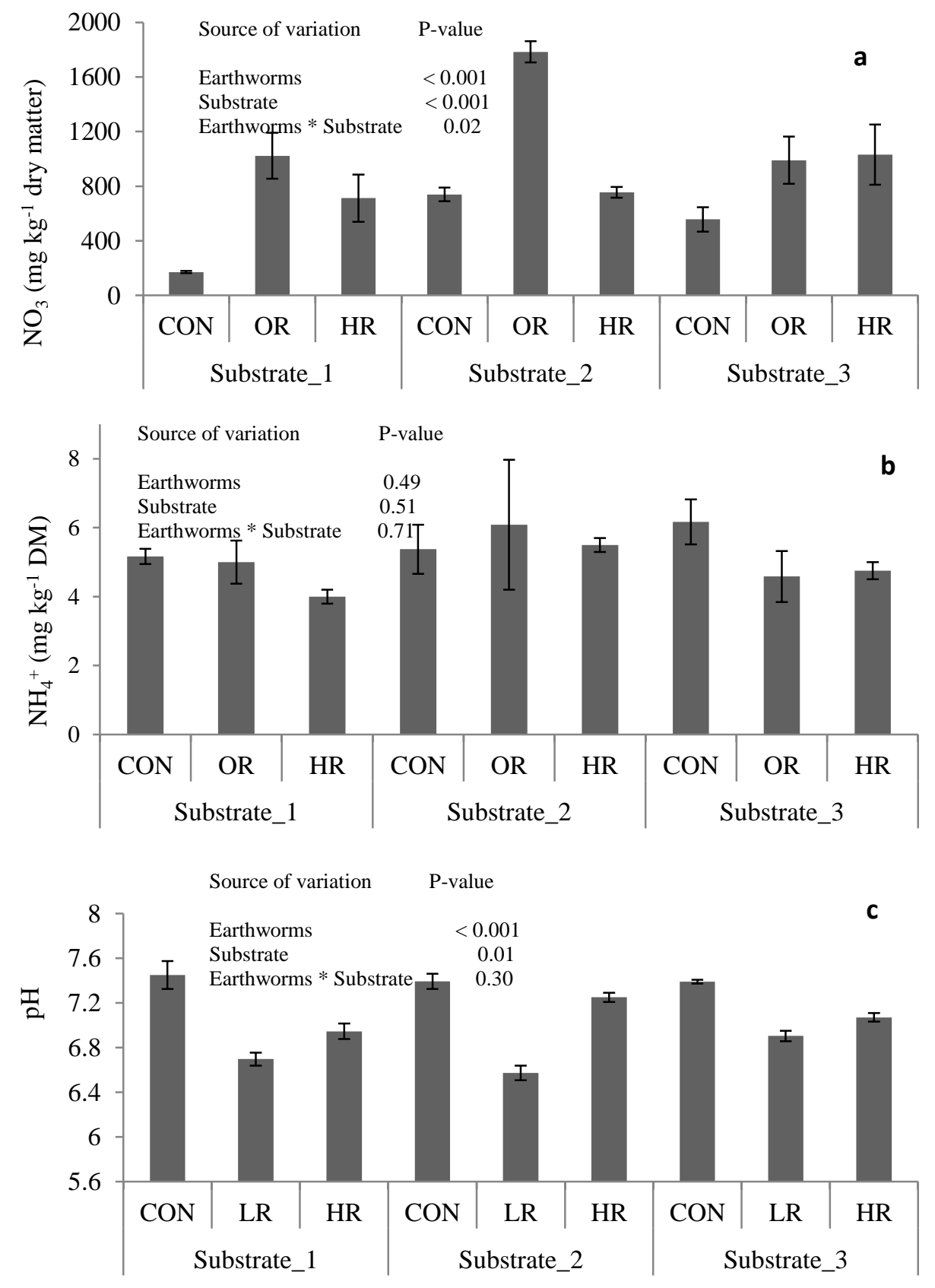

Figure 5.4. Chemical properties of the composts after 60 days of composting (mean \pm standard error of the mean; $\mathrm{n}$ = 3). (a) $\mathrm{NO}_{3}^{-}$(b) $\mathrm{NH}_{4}{ }^{+}(\mathrm{c}) \mathrm{pH}$. $\mathrm{CON}$ = without earthworms, OR = optimal substrate-toearthworm ratio, $\mathrm{HR}=$ high substrate-to-earthworm ratio 


\section{Earthworm biomass}

The change in earthworm biomass was significantly affected by substrate quality $(\mathrm{P}=$ $0.01)$, but not by feeding ratio $(\mathrm{P}=0.03)$ or the interaction $(\mathrm{P}=0.24)$. The substrate that pre-decomposed for nearly $1 \frac{1}{2}$ months resulted in the highest increase in earthworm biomass (Fig. 5.5).

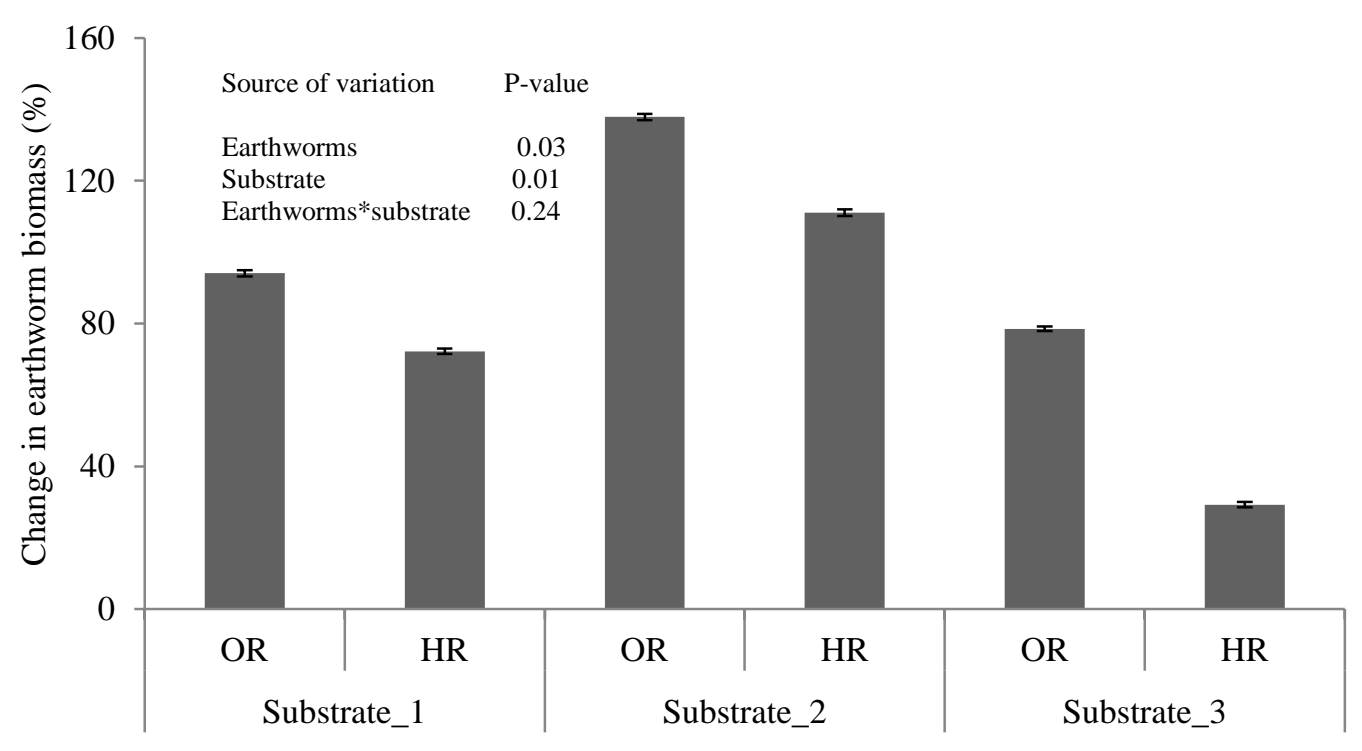

Figure 5.5. Change in earthworm biomass after 60 days of vermicomposting. $L R=$ optimal substrateto-earthworm ratio, $\mathrm{HR}=$ high substrate-to-earthworm ratio

\section{Discussion}

\section{DOC quantity and composition}

The hypothesis that earthworms decreased the concentration of DOC compared with the non-earthworm treatment was confirmed. The result was consistent with the increase in $\mathrm{C}$ mineralisation caused by the earthworms (Figs. 5.2a and 5.3a). In agreement with our findings, Hanc and Dreslova (2016) and Lazcano et al. (2008) found a lower DOC content after vermicomposting than after thermophilic composting. A new vermicomposting parameter (i.e. feeding ratio) was considered in the present study, and demonstrated to have a significant effect on the DOC concentration (Fig. 5.1). The optimum feeding ratio was found to decrease the DOC concentration by 5-14\% compared with the high feeding ratio. The effect of feeding ratio on DOC was largest in the substrate that had undergone a shorter pre-composting period (substrate_3). DOC contains easily degradable compounds and its concentration declines consistently with composting time (ZmoraNahum et al., 2005). Similarly, it was found that composts that had undergone a longer pre-composting period had a lower DOC content. The significant correlation between DOC concentration and $\mathrm{CO}_{2}$ emissions from the last week of composting $\left(\mathrm{r}^{2}=0.63 ; \mathrm{P}=\right.$ 
0.001) (Fig. 5.2a) confirmed that existence of active decomposition process in the substrates containing a high DOC content. The DOC concentration of compost influences microbial activities and C mineralisation after soil application (Straathof et al., 2014) and hence it is used as an indicator of compost stability (Zmora-Nahum et al., 2005). Composts with a low DOC content (less than $4 \mathrm{~g} \mathrm{~kg}^{-1}$ dry matter) are considered more stable (Bernal et al., 2009), implying that the earthworms, especially at optimum feeding ratios, stabilise compost more quickly than non-earthworm treatments. The possible explanation for the higher stabilisation caused by earthworms is that they enhance the decomposition process through their interaction with microorganisms. Substrate_3 was not fully stable because it had high total DOC content (5-6 $\mathrm{g} \mathrm{kg}^{-1}$ dry matter), and it is mainly due to the presence of manure that went through a pre-decomposition period for few days. The DOC concentration observed in this study was comparable with the earlier composting studies (Zmora-Nahum et al., 2005; Hanc and Dreslova, 2016), which reported a DOC concentration in the range 3-6 $\mathrm{g} \mathrm{kg}^{-1}$ dry matter. However, Straathof and Comans (2015) reported a low DOC content $\left(<0.5-1.0 \mathrm{~g} \mathrm{~kg}^{-1}\right.$ dry matter) in some compost, although their municipal-waste compost also contained high amounts of DOC $\left(5-7 \mathrm{~g} \mathrm{~kg}^{-1}\right.$ dry matter). However, their values cannot be directly compared with our results, as in their composts organic materials were mixed with soil prior to composting. After correcting for non-organic (mineral) soil components, their compost contained between 2-3 $\mathrm{g} \mathrm{kg}^{-1}$ dry organic matter (compost with woody material or forest leaf litter) and up to $19 \mathrm{~g} \mathrm{~kg}^{-1}$ dry matter (for municipal organic waste). Current literature often reports the DOC concentration per dry matter without considering the mineral fractions of compost materials (i.e. soils). Hence, we recommend that DOC be expressed per weight of organic materials after discounting mineral content in order to assess compost stability. In our study, however, only organic materials were used and hence the DOC values could be used directly to indicate compost stability.

The concentrations of different DOC compositions (FA, HA, HON and Hi) was affected by the earthworm treatments, substrate quality and their interaction (Table 5.1). The presence of earthworms decreased concentrations of FA and HA, whereas the concentrations of all four components of DOC were lower in vermicompost than in compost in the absence of worms. The low concentration of the DOC fractions in the earthworm treatments coincided with the decrease in the total DOC concentration (Fig. 5.1). Therefore, the relative proportion of each fraction to total DOC (Supplementary Fig. 5.1) could provide more reliable information on the earthworms' effect on DOC composition and the turnover of the fractions during composting.

Straathof and Comans (2015) reported the DOC composition of composts produced from different input materials and processing conditions and noted significant variation in the relative contribution of $\mathrm{HA}, \mathrm{FA}, \mathrm{HON}$ and $\mathrm{Hi}$ in the various composts. Our study showed only small effects of treatments and substrate on the fractional contribution to total DOC. One major explanation for the discrepancy is that these 
authors used a larger range of input material (from wood and forest leaf litter to municipal waste) and there were also large differences between composting practices (temperature, time).

We hypothesised, in agreement with Straathof and Comans (2015) that during the composting process, $\mathrm{Hi}$ compounds are depleted more quickly than the three hydrophobic compounds because the hydrophilic fraction consists of low-molecularweight sugars and amino acids, which are readily available $C$ sources for microorganisms. Straathof and Comans (2015) reported a lower Hi proportion, but higher proportions of $\mathrm{HA}, \mathrm{FA}$ and $\mathrm{HON}$ in composts that had undergone a longer composting period and high temperature $\left(>70{ }^{\circ} \mathrm{C}\right)$ compared with composts produced at a lower temperature with a composting period of $<28$ days (i.e. unstable compost). They suggested that the fractional contribution of Hi to DOC may be a better indicator for the contribution of compost on microbial activity. However, our data contradict this hypothesis. In fact, the fractional contribution of HA declined with increasing stability; and a ranking of the compounds with increasing stability was $\mathrm{HA}>\mathrm{DOC} \approx \mathrm{FA} \approx \mathrm{Hi}>$ HON. We suggest two hypotheses to explain why HA turned out to be the least stable component. First, decline of HA (and FA to a smaller extent) is likely indicative for ligninolysis, whereas decline of $\mathrm{Hi}$ is indicative for cellulolysis. While it has for a long time been taken for granted that degradation of lignin proceeds at a slower rate than degradation of cellulose, recent data have actually indicated a faster decomposition of lignin than cellulose (Klotzbücher et al., 2011). Second, changes in the various pools are driven both by depletion of the compound during decomposition but also by novel production during degradation and / or changes in solubility of compounds. Van Zomeren and Comans (2007) put their study in the framework of a novel perspective on humic substances as supramolecular associations of compounds with relatively small mass, and observed that at declining HA concentrations the chances increased that part of the HA fraction actually showed up in the FA fraction. Further research is needed to evaluate both potential mechanisms. Considering that the concentrations of HA and FA, but not those of $\mathrm{HON}$ and $\mathrm{Hi}$, were lower in the vermicompost than in the non-worm compost, independent of the total amounts of DOC, we hypothesise a role of earthworms and their associated microbes in the breakdown of aromatic polymers like lignin. Earthworms also secrete mucus, and these compounds may be rich in carbohydrates and proteins (Pan et al., 2010) that may also preferentially end up in the Hi fraction. Next to the fractional contribution of individual compounds, the ratio of hydrophilic to hydrophobic substances ( $\mathrm{HA}+\mathrm{FA}+\mathrm{HON})$ may provide indications of compost stability. Our compost showed ratios between 0.20 and 0.30 , while the study of Straathof and Coomans (2015) indicated ratios of 0.66-0.79 for unstable composts.

To our knowledge, however, no studies have been conducted to assess the effect of earthworms on DOC composition. Further studies are therefore recommended to advance understanding of the effect of earthworms on the DOC pools using different 
parameters such as substrate quality (i.e. fresh organic material), earthworm species and earthworm density.

\section{Greenhouse gas emissions}

As hypothesised, earthworms increased $\mathrm{CO}_{2}$ emissions compared with non-earthworm treatments, and the results were comparable with earlier studies (Chan et al., 2010; Nigussie et al., 2016). Similarly, the $\mathrm{CO}_{2}$ emissions from vermicomposting were higher at optimum feeding ratio than at the high ratio, as hypothesised. Higher cumulative $\mathrm{CO}_{2}$ emissions indicated a greater stability of compost and confirmed that the earthworms resulted in compost which was at a more advanced stage of stabilisation. The $\mathrm{CO}_{2}$ results were in agreement with the observation on DOC quantity (Fig. 5.1).

The hypothesis that the high feeding ratio increases $\mathrm{N}_{2} \mathrm{O}$ emissions from vermicomposting was confirmed. As compared to the non-earthworm treatment, earthworms decreased $\mathrm{N}_{2} \mathrm{O}$ emissions by $23-48 \%$ at the optimum feeding ratio. At the higher ratio, however, earthworms had no significant effect on $\mathrm{N}_{2} \mathrm{O}$ emissions compared with the non-earthworm treatments. The low $\mathrm{N}_{2} \mathrm{O}$ production in the earthworm treatments could be explained by: (i) continuous turning of substrates by earthworms which subsequently increases aeration (Chan et al., 2010; Nigussie et al., 2016) and (ii) high substrate stability after it has passed through the earthworms' gut (Luth et al., 2011). Hence, the low DOC concentration as evidence for compost stability (Fig. 5.1) could explain the low $\mathrm{N}_{2} \mathrm{O}$ emissions in the earthworm treatments. At the higher feeding ratio, however, the presence of anaerobic patches and the lower degree of stabilisation (Fig. 5.1) reduced the mitigation effect of earthworms on $\mathrm{N}_{2} \mathrm{O}$ emissions.

Reports on the effect of earthworms on $\mathrm{N}_{2} \mathrm{O}$ emissions are contradictory. For instance, Hobson et al. (2005) and Lubbers et al. (2012) reported earthworm-induced $\mathrm{N}_{2} \mathrm{O}$ emissions. In contrast, Chan et al. (2011), Nigussie et al. (2016) and Wang et al. (2015) found that earthworms decreased $\mathrm{N}_{2} \mathrm{O}$ emissions during composting. The contrasting results can be explained by differences in earthworm species (i.e. difference in their feeding and burrowing behaviours) (Lubbers et al., 2013), substrate quality (i.e. carbon quality and nitrogen content) (Luth et al., 2011; Nigussie et al., 2016), temperature (Nigussie et al., 2016) and the scale of the experiment (Chan et al., 2010). In our study the decreasing effect of earthworms on $\mathrm{N}_{2} \mathrm{O}$ emissions occurred at optimum feeding ratio, while at a high feeding ratio earthworms did not decrease $\mathrm{N}_{2} \mathrm{O}$ emission, implying that feeding ratio is an important parameter for consideration when assessing the earthworms' effect on GHG emissions during composting. Denitrification in the earthworm gut was the main process contributing to $\mathrm{N}_{2} \mathrm{O}$ emissions in the case of anecic earthworms (Lubbers et al., 2013). Composting materials mostly contain high levels of nitrogen, hence the contribution of denitrification occurring in the earthworm gut to total $\mathrm{N}_{2} \mathrm{O}$ emissions was smaller than the contribution from denitrification in the environment 
around the worms. Furthermore, the feeding and burrowing behaviours of earthworms mostly used in soil experiments (i.e. anecic earthworms) are different from compost worms.

Two scenarios were used to assess the effect of earthworm treatments on total GHG emissions. The first scenario excluded $\mathrm{CO}_{2}$ because higher $\mathrm{CO}_{2}$ emissions indicate a greater stability of the material. Including $\mathrm{CO}_{2}$ in the $\mathrm{GHG}$ balance would therefore privilege composts that are not stabilised over the course for the experiment, and therefore provide a biased assessment how earthworms affect the GHG balance (Chowdhury et al., 2014). Under this scenario, the effect of earthworm treatments on the total GHG emissions was similar to their effect on $\mathrm{N}_{2} \mathrm{O}$ emissions since the contribution of $\mathrm{CH}_{4}$ was negligible. However, when $\mathrm{CO}_{2}$ was included in the total GHG budget, the earthworm treatments increased total GHG emissions compared with the nonearthworm treatments. This variation was explained by the high $\mathrm{CO}_{2}$ emissions in the earthworm treatments (Fig. 5.3a), and the large contribution of $\mathrm{CO}_{2}$ to the total GHG budget in all treatments $(>80 \%)$. These results are comparable with previous studies on composting (Anderson et al., 2010; Nigussie et al., 2016).

\section{Properties of compost}

Irrespective of substrate quality, the presence of earthworms and optimum feeding ratio decreased $\mathrm{pH}$, but increased the $\mathrm{NO}_{3}{ }^{-}$concentration. The high $\mathrm{NO}_{3}$ - concentration in the earthworm treatments and optimum feeding ratio was explained by the mineralisation of $\mathrm{N}$ from the organic materials and /or reduced $\mathrm{N}_{2}$ losses through denitrification (Fig. 5.3b). The $\mathrm{NH}_{4}{ }^{+}$concentration decreases during decomposition due to ammonia volatilisation and nitrification processes, while the $\mathrm{NO}_{3}$ - concentration increases towards the end of the composting period. Hence, the $\mathrm{NH}_{4}{ }^{+}: \mathrm{NO}_{3}{ }^{-}$ratio has been used to assess the maturity of compost (Bernal et al., 2009), and the threshold value of $<0.16$ is an indicator of mature compost, implying that all the composts were mature. Still the earthworm treatments produced more mature compost than the non-earthworm treatments. We used the total DOC content and $\mathrm{NH}_{4}{ }^{+}: \mathrm{NO}_{3}{ }^{-}$ratio to estimate compost stability, and both indices yield the same result except for substrate_3. The presence of manure increased the $\mathrm{NO}_{3}{ }^{-}$concentration in substrate_3, subsequently reduced the $\mathrm{NH}_{4}{ }^{+}$ : $\mathrm{NO}_{3}{ }^{-}$ratio, suggesting that $\mathrm{NH}_{4}{ }^{+}: \mathrm{NO}_{3}{ }^{-}$ratio depends on the substrate quality and hence it may not be a reliable index compared with DOC. The decrease in $\mathrm{pH}$ values in the earthworm treatments at optimum feeding ratio could be due high nitrification in these treatments (Fig. 5.4a) and the production of organic acids as a result of greater decomposition (Fig 5.1 and 5.3a) (Lazcano et al., 2008).

The data presented here confirmed a significant effect of feeding ratio on the stabilisation of organic material (Fig. 5.1), GHG emissions (Fig. 5.3) and properties of the end product (Fig. 5.4), however (applied) researchers on vermicomposting have paid 
little attention to feeding ratio. Feeding ratio influences earthworm growth (Fig. 5.5: Luth et al., 2011), aeration and temperature, subsequently affecting decomposition, mineralisation, nutrient losses and GHG emissions. Hence, it is suggested that this ratio be considered an equally important parameter when evaluating the effectiveness of earthworms in the stabilisation of organic materials to parameters such as earthworm species, substrate quality etc.

\section{Conclusions}

Earthworms accelerated the stabilisation of organic materials compared with the nonearthworm treatments, as confirmed by $\mathrm{CO}_{2}$ production, DOC concentration, DOC composition and $\mathrm{NH}_{4}{ }^{+}: \mathrm{NO}_{3}{ }^{-}$ratio. Earthworms decreased the total DOC concentration, but they did not affect the relative composition of hydrophilic, fulvic acid and hydrophobic neutral fractions. The relative contribution by humic acid decreased in the earthworm treatments, implying that the humic acid fraction was less recalcitrant as commonly assumed, and was likely used as a substrate by microorganisms. The hydrophilic-to-hydrophobic ratio was consistent between the different stable composts, despite differences between input materials and processing conditions, and this ratio could be used as an additional criterion to assess compost stability. This ratio is much higher for unstable composts, implying that it can be used as an indicator of compost stability. Fractionation of DOC is therefore important for understanding the stabilisation of organic waste. A higher (supra-optimal) feeding ratio reduced the stabilisation process and increased $\mathrm{N}_{2} \mathrm{O}$ emissions compared with the optimum feeding ratio. Hence feeding ratio should be considered as an important parameter when assessing the earthworms' effect on the stabilisation of organic materials and GHG emissions during composting.

\section{Acknowledgements}

This study was conducted as part of a PhD thesis project supported by the Agricultural Transformation by Innovation (AgTraIn) Erasmus Mundus Joint Doctorate Programme, funded by the EACEA (Education, Audio-visual and Culture Executive Agency) of the European Commission. The authors would like to thank Mr Jaap Nelemans for laboratory assistance, Mr. Lou Derks from De Polderworm for providing the earthworms and technical advice, and prof. Rob Comans for helpful discussion on DOC fractionation and the interpretation of the various fractions. 


\section{Appendix}

substrate_1 (CON)

口 HA_\%

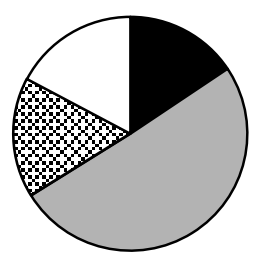

$\square$ FA_\%

⿴囗十ON_\%

$\square$ HI_\%

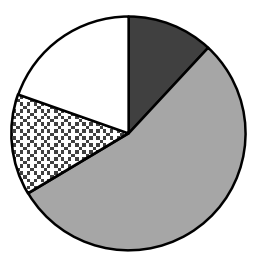

substrate_1 (HR)
substrate_1(OR)
口HA_\%

$\square$ FA_\%

图HON_\%

$\square$ HI_\%

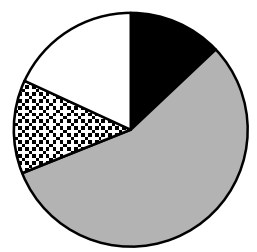

口HA_\%

口FA_\%

⿴囗十) HON_\%

$\square$ HI_\% substrate_2 (CON)

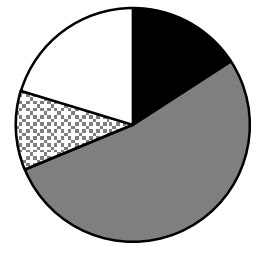

substrate_2(OR)

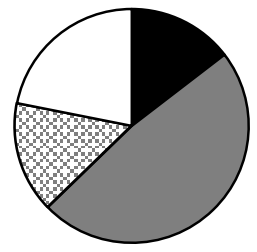

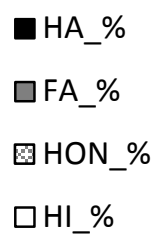

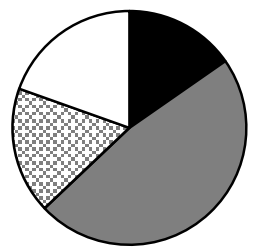

口HA_\%

$\square \mathrm{FA} \%$

๑HON_\%

$\square$ HI_\% substrate_3 (CON)

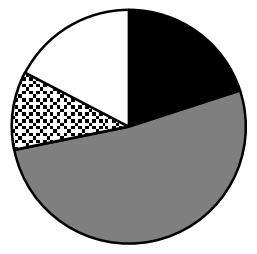

substrate_3 (OR)

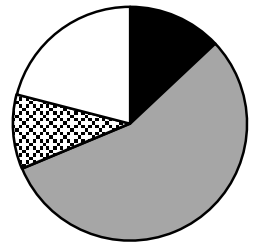

DHA_\%

$\square$ FA_\%

国HON_\%

$\square$ HI_\%
substrate_2(HR)

Supplementary Figure 5.1. Relative composition of dissolved organic carbon (DOC) from different treatments after 60 days of composting. $\mathrm{CON}=$ without earthworms, $\mathrm{LR}=$ with earthworms and lower substrate input, $\mathrm{HR}=$ with earthworms and higher substrate input, $\mathrm{HA}=$ humic acid, FA = fulvic acid, $\mathrm{HON}=$ hydrophobic neutral, $\mathrm{Hi}=$ hydrophilic compounds. 
Chapter 5 


\section{CHAPTER 6}

General discussion 


\section{Introduction}

Many smallholder farming systems in developing countries are characterised by low agricultural inputs, such as improved seed varieties, mineral fertilisers and organic amendments (i.e. crop residues, manure, compost). Numerous efforts have been made to improve soil fertility and crop yield using mineral fertilisers and/or organic amendments (Mann and Warner, 2015). Organic amendments maintain or increase soil organic matter contents and thereby contribute to enhanced fertiliser use efficiency. Despite the benefits of organic amendments, many smallholder farmers do not retain crop residues or manure on their farmlands and as a result, a large quantity of nutrients and carbon (C) is exported from agricultural lands to markets/cities. The use of other sources, such as urban-waste compost, has been therefore proposed to close nutrient and C cycles (Danso et al., 2006; Mary et al., 2010).

Many efforts have recently been made to prepare compost from urban-waste. In developed countries urban-waste compost has been applied to farmlands to improve soil properties (Peltre et al., 2015) and crop yield (Getahun et al., 2012b) without any negative effect on the surrounding soil or water bodies (Poulsen et al., 2013). However, no attention is paid to urban-waste compost in developing countries, despite a large amount of organic waste being produced in cities, and this has become a matter of global concern. A lack of institutional involvement is the main driver behind the limited use of urban-waste compost as a soil amendment. Urban-waste composting requires farmers' participation and hence studies are needed with regard to their attitudes to urban-waste compost in order to optimise its economic benefits. In addition to this, urban-waste composts usually have low content of nutrients especially nitrogen (Hargreaves et al., 2008), therefore studies are required on how to produce nutrient-rich compost at the lowest cost. N-rich composts are produced by composting urban waste with $\mathrm{N}$-rich substrates such as manure, however this process results in high $\mathrm{N}$ losses and greenhouse gas emissions (Chapters 3 and 4) and subsequently reduces the agronomic value of compost and contributes to climate change. As described in Chapter 1, the main aims of this thesis were therefore (i) to contribute to and strengthen knowledge about the challenges and opportunities of utilising urban-waste compost as a soil amendment, particularly in smallholder farming systems, and (ii) to develop low-cost technologies that improve the fertilising values of urban-waste compost while reducing losses to the environment and alleviating climate change through the reduction of GHG emissions.

The findings of this thesis come from socioeconomic studies and composting experiments conducted both in laboratory reactors and under field conditions. In this chapter, I summarise and contextualise the key findings of the thesis with respect to the hypotheses stated in Chapter 1. I start by recalling the hypotheses in order to evaluate whether they were confirmed. I then discuss whether urban-waste composting can be used as a soil amendment in developing countries. Thirdly, I examine low-cost 
technologies that could be used to reduce $\mathrm{N}$ losses and GHG emissions from composting before finally concluding my results and offering suggestions for further studies.

\section{The findings}

Despite the benefits of organic amendments on soil properties and crop yield, only a small number of farmers retain agricultural waste on their farmlands. In Ethiopia, for example, less than $30 \%$ of farmers retain crop residues and/or applied manure on their farmlands (Nigussie et al., 2015), and in the latter case farmers usually apply organic amendments at low rates $\left(<1 \mathrm{t} \mathrm{ha}^{-1}\right)$ (Baudron et al., 2014). The second chapter of my thesis was therefore designed to answer the question: Why do farmers retain no or insufficient agricultural waste on their farmlands? Low crop production, a limited number of animals, insufficient collection of manure and limited availability of labour have been identified as major causes behind the limited use of agricultural waste (Tittonell et al., 2005, Kassie et al., 2009; Baudron et al., 2014). I added a further dimension to this issue and hypothesised that competition for agricultural waste (as animal feed, building material, fuel and soil amendments) is a major explanatory factor behind the limited use of soil amendments and soil fertility enhancement. This hypothesis was confirmed by my results (Chapter 2). I interviewed 220 farmers in Addis Ababa, Ethiopia and observed that crop residues were mainly used for feed and fuel and that manure was used for fuel (Fig 6.1). Manure is a source of fuel even for urban dwellers, probably due to high poverty in urban areas. This high poverty-driven demand creates market opportunities and entices farmers to sell their agricultural waste to nearby cities, further exacerbating carbon and nutrient fluxes from the countryside to cities. I also hypothesised that the allocation of agricultural waste varies between different farmer groups. Farmers with market-oriented production systems allocate their agricultural waste mainly for soil amendments compared with resource-poor subsistence farmers. Socioeconomic variables such as land ownership, shortage of land and access to extension services also influence farmers' decisions to retain agricultural waste on their farmlands.

The use of other sources (e.g. urban waste) has been suggested as an alternative soil amendment, particularly for urban and peri-urban farmers (Danso et al., 2006). Extensive literature is available on the effect of urban-waste compost on soil properties (Peltre et al., 2015) and crop yield (Hargreaves et al. 2008). Despite the beneficial effects of urban-waste compost, $<5 \%$ of urban waste is converted into compost (Mengistu, 2013). I expanded the second chapter to address the question: Is there a demand from (perurban farmers for urban-waste compost? I hypothesised that there is indeed a demand for urban-waste compost, but that this demand varies between different farmer groups. I observed that about $60 \%$ farmers were willing to pay or contribute labour for urbanwaste composting. Farmers with market-oriented production systems showed a higher demand than resource-poor subsistence farmers. Education, distance between the 
farmland and the city, land tenure status, experience with compost and access to extension services explained the variation in compost demand and willingness to pay for or contribute to the acquisition of compost.

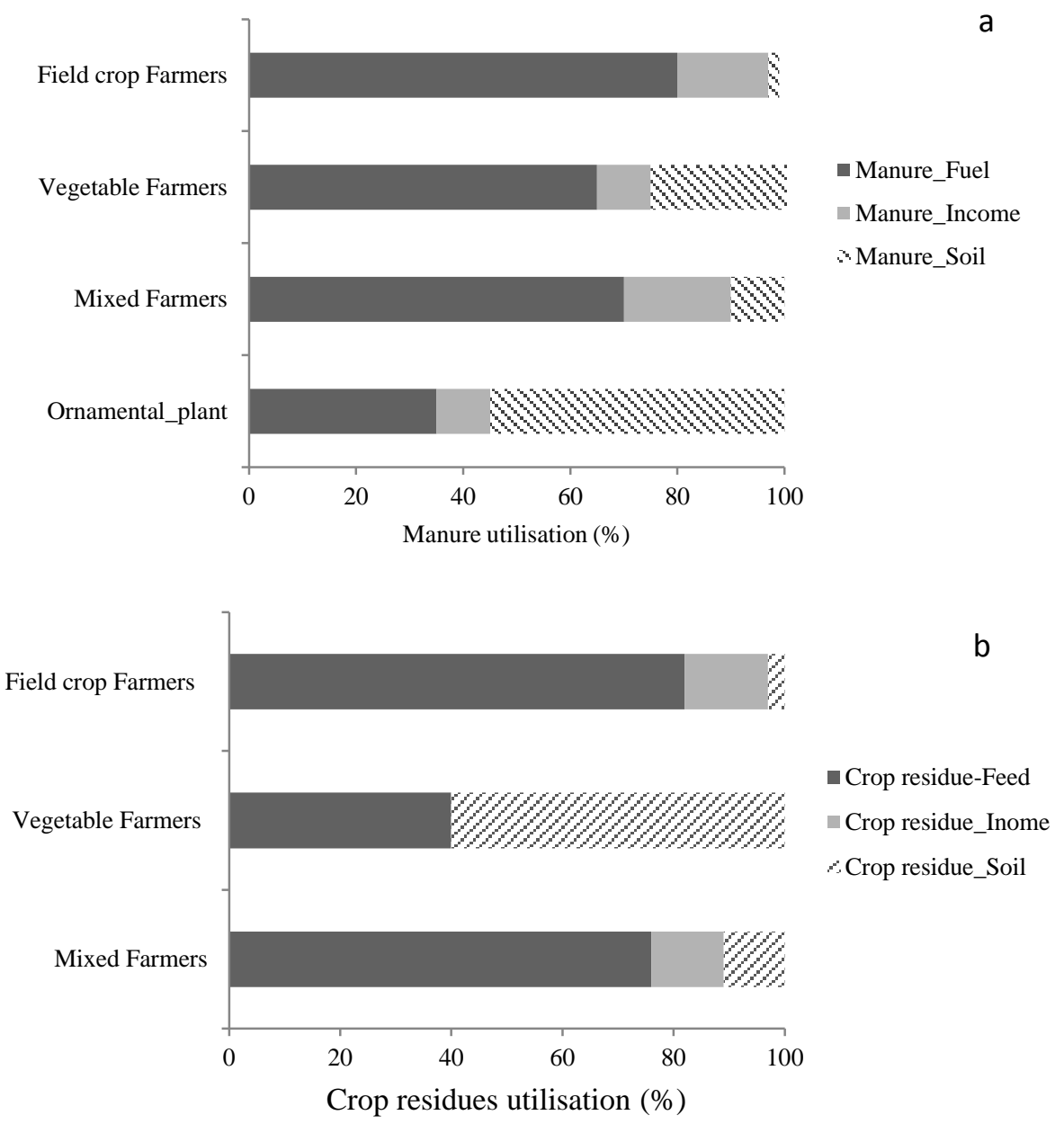

Figure 6.1: Current use of manure (a) and crop residues (b) across different urban and peri-urban farmer groups

Even though urban-waste compost was suggested as an alternative soil amendment in Chapter 2, high $\mathrm{N}$ losses, especially through volatilisation of $\mathrm{NH}_{3}$, and greenhouse gas (GHG) emissions by $\mathrm{N}_{2} \mathrm{O}$ and $\mathrm{CH}_{4}$ still represent a challenge during the composting of N-rich urban waste materials (Anderson, 2010). Different strategies have been suggested to reduce N losses and GHG emissions (Steiner et al., 2010; Chowdhury et al., 2014; Kahn et al., 2016), but these are expensive and difficult to scale up to field conditions. Chapters 3,4 and 5 were therefore initiated to develop technologies that could easily fit with existing farming systems.

Earthworm composting (vermicomposting) is a mesophilic $\left(<30^{\circ} \mathrm{C}\right)$ process (see Box 6.1). It is known that lower temperatures during composting reduce $\mathrm{N}$ losses via ammonia volatilisation. Earthworms improve air circulation (which prevents the temperature increase) in the compost pile through continuous turning of the substrate 
(Luth et al., 2011). Increased aeration prevents anoxia and reduces GHG emissions. In chapter 3, I reported that vermicomposting, compared to thermophilic composting, reduces $\mathrm{NH}_{3}$ losses and GHG emissions. I demonstrated that vermicomposting decreased total $\mathrm{N}$ losses by $20 \%$ compared with thermophilic composting. The highest reduction of $\mathrm{N}$ losses by earthworms was observed with substrates at lower $\mathrm{C}: \mathrm{N}$ ratios. Existing reports on the effect of earthworms on GHG emissions are contradictory. Hence, I used different quality substrates (as assessed by $\mathrm{C}: \mathrm{N}$ ratio and the presence of a labile $\mathrm{C}$ pool) and manipulated several variables (moisture content, earthworm density and feeding ratio) to clarify understanding of the effect of earthworms on GHG emissions during composting.

\section{BOX 6.1. Composting methods}

Thermophilic composting and vermicomposting are commonly used composting techniques. There are two phases in thermophilic composting: the first is the thermophilic (active) stage, in which rapid decomposition takes place and temperatures rise above $45^{\circ} \mathrm{C}$ and the second is known as the maturation or curing stage, in which the temperature decreases to ambient value and more stable organic compounds are degraded at a lower rate. Vermicomposting is a mesophilic $\left(<30{ }^{\circ} \mathrm{C}\right)$ process that involves earthworms and associated microorganisms in decomposing and stabilising organic materials. The temperature during vermicomposting should remain within a range of $15-30^{\circ} \mathrm{C}$ as temperatures above $35^{\circ} \mathrm{C}$ kill earthworms.

The mesophilic phase of composting can be achieved by continuously turning the pile (without using earthworms), but this method requires labour and excessive aeration could result in $\mathrm{NH}_{3}$ emissions. In my thesis, one experiment compared vermicomposting with thermophilic composting, while the other two compared mesophilic composting in the presence and absence of earthworms. In all these experiments, I demonstrated that earthworms play an important role in mitigating $\mathrm{N}$ losses and GHG emissions during composting.

Earthworms decreased $\mathrm{CH}_{4}$ emissions from composting, and this observation was consistently found in all the experiments. Similarly, earthworms decreased $\mathrm{N}_{2} \mathrm{O}$ during vermicomposting compared to thermophilic composting, but I observed that the earthworm effect varied between substrate quality and earthworm density and feeding ratio (Chapter 3 and Chapter 5). A higher earthworm abundance (Chapter 3) and feeding ratio (Chapter 5) increased $\mathrm{N}_{2} \mathrm{O}$ emissions during vermicomposting. A comparison between Chapter 3, Chapter 5 and our unpublished data (Motta et al., unpublished) also suggested that different species of epigeic earthworms used for vermicomposting could result in different GHG emissions. Earthworms increased $\mathrm{CO}_{2}$ emissions, and this observation was consistent in all experiments (Chapter 3 and Chapter 5). Earthworms 
increased $\mathrm{CO}_{2}$ emissions by up to $14 \%$. While higher $\mathrm{CO}_{2}$ evolution might suggest a greater contribution to GHG emissions, it should be noted that in the end all composts are likely to be of a similar stability as more $\mathrm{CO}_{2}$ might escape after the compost is applied to the field. Therefore higher $\mathrm{CO}_{2}$ evolution indicates a greater degree of stabilisation of the compost and hence it should not be considered as GHG (Vu et al., 2014). I therefore calculated total GHG emissions from the different treatments (Chapters 3) considering only $\mathrm{N}_{2} \mathrm{O}$ and $\mathrm{CH}_{4}$ emissions. Accordingly, I confirmed that the use of earthworms (vermicomposting) reduced GHG emissions compared with non-earthworm treatments (thermophilic composting).

While vermicomposting is effective at reducing $\mathrm{N}$ losses and GHG emissions from composting, high $\mathrm{N}$ losses, however, occur during composting of nitrogen-rich materials. Studies show low levels of $\mathrm{N}$ in urban-waste compost, particularly in (sub-)tropical countries (Getahun et al., 2012b), that negatively impact on compost quality from a soil fertility perspective. Composting of (N-poor) urban waste together with $\mathrm{N}$-rich materials such as manure is commonly used to increase the $\mathrm{N}$ content of the final compost (Lhadi et al., 2006; Rizzo et al., 2015). This practice could result in significant $\mathrm{N}$ losses $\left(\mathrm{NH}_{3}\right.$ volatilisation) due to the combination of high temperatures $\left(>45^{\circ} \mathrm{C}\right)$ during the thermophilic phase and high $\mathrm{NH}_{4}{ }^{+}$concentration in the N-rich substrate. Chapter 4 was therefore initiated to test the hypothesis that the addition of N-rich substrate after the thermophilic phase reduces $\mathrm{N}$ losses. I also tested the hypothesis that the timing of $\mathrm{N}$ rich substrate addition influences $\mathrm{N}_{2} \mathrm{O}$ and $\mathrm{CH}_{4}$ emissions. I noted that delayed addition reduced $\mathrm{N}$ losses up to $20 \%$. In addition to this, I demonstrated that delayed addition increased $\mathrm{N}_{2} \mathrm{O}$ emissions by $400-600 \%$, but decreased $\mathrm{CH}_{4}$ emissions by $50 \%$. The mechanisms of how delayed addition influences GHG emissions have not been investigated in my thesis, hence further studies are required to identify these mechanisms.

In my thesis (Chapter 3), I found that earthworms increased $\mathrm{CO}_{2}$ emissions, indicating that vermicomposting increase the stabilisation process compared with traditional composting method. Hence I proposed Chapter 5 to determine the effect of earthworms on the dissolved organic carbon (DOC) quantity and its various fractions which are recently proposed indices of compost stability. A consequence of higher compost stability is a lowering of the contents of DOC and its various fractions, an issue more extensively studied in Chapter 5. I expanded this chapter to address the effect of feeding ratio (i.e., the ratio of earthworms to substrate added) on the GHG emissions and compost stability. I demonstrated that optimum feeding ratio reduced GHG emissions and accelerated the stabilisation of organic materials compared with higher feeding ratio. 


\section{Challenges and opportunities of using organic amendments in developing countries}

As shown in Chapter 2, competition between fuel and feed is a major explanatory factor in explaining the insufficient application of agricultural waste on croplands. Furthermore Baudron et al. (2014), Rimhanen and Kahiluoto (2014) and Valbuena et al. (2015) found that $<20 \%$ of crop residues are retained on croplands in sub-Saharan and South Asian counties because the majority of crop residues are used for feed and fuel. Similarly, small amounts of manure (usually $<1 \mathrm{t} \mathrm{ha}^{-1} \mathrm{yr}^{-1}$ ) are applied on farmlands (Chapter 2), even in farming systems where cattle density is high (Baudron et al., 2014) because manure is the main source of fuel. How to fulfil the demand for both animal feed and household fuel on the one hand and soil on the other still presents a challenge. The use of other energy sources such as kerosene, electricity and fuel wood could be an option for reducing existing pressure on manure and crop residues. However, theses energy sources are not affordable and/or accessible. High deforestation results in limited access to fuelwood (Haileselassie et al., 2006; Mekonnen and Köhlin, 2009; Damte et al., 2012), hence efforts should be made to increase accessibility to alternative energy sources so that manure and crop residues can be used mainly as a soil amendment. However, this is not a simple solution that can be achieved in the short term because it is expensive for many (sub)tropical countries.

Intensification of crop and livestock production is another option for feeding livestock as well as utilising crop residues as a soil amendment. Baudron et al. (2014) and Valbuena et al. (2015) suggest that closing the yield gap provides sufficient amounts of crop residue for feed and soil amendments. Livestock intensification also increases the amount of manure produced, meaning that larger quantities of manure can be applied on croplands (Abdulkadir et al., 2012; Vu et al., 2012). Intensification of crop and/or livestock production requires higher inputs such as the application of fertilisers, the use of improved crop varieties and the control of yield-reducing factors such as weeds, pests and diseases.

Despite the fact that many countries having been promoting intensified agricultural management practices for the past three decades, many farmers still apply fertilisers (far) below the recommended rate due to their high price (Kassie et al., 2009; Chapter 2), without complementary inputs (organic amendments). Due to soil fertility problems and further yield-reducing factors, the yield gap reaches about $40 \%$ (Getnet et al., 2016; Mann and Warner, 2015). Therefore the current limited use of fertiliser could still result in negative returns for many farmers, thereby resulting in stagnation of further intensification (Valbuena et al., 2015). In developing countries such as Ethiopia, farmers also have a farm size of less than one ha and agricultural products are mainly used for household consumption. Hence, little or no surplus production is available to purchase inputs. Thus, farmers are caught in a vicious circle of low agricultural 
production (a large yield gap) and low income, even though several attempts have been made to address these problems (Tittonell and Giller, 2013). It is well recognised that farmers and possibly even governments will be unable to afford an increase in the application rate of fertilisers. It is therefore essential to improve current policies, infrastructure, markets and financial institutions to enable intensification of crop and livestock production so that the competition for agricultural waste can be reduced.

Throughout my thesis efforts to re-use urban waste as a soil amendment have been explored because the current utilisation of manure and crop residues results in the export of nutrients and $C$ from farmlands to cities. Hence urban-waste composting is a crucial strategy for closing the rural-urban nutrient loop and sequestering $\mathrm{C}$ in soils. In addition to this, urban-waste composting is important for solid waste management because a large amount of biodegradable waste is produced, and waste management has become or is likely to become a major concern in developing countries in the near future since there is barely any waste management and urban populations are rapidly increasing (Marshall and Farahbakhsh, 2013; Danso et al., 2008). The current waste management strategy (i.e. landfill) pollutes the surrounding soil and groundwater and produces potent greenhouse gases such as methane $\left(\mathrm{CH}_{4}\right)$ (Regassa et al., 2011, Mengistu, 2013, Bernard-Beltrán et al., 2014).

As shown in Chapter 2, many (peri-)urban farmers were willing to apply urbanwaste compost on their farmlands, which is comparable with a previous study in Ghana (Danso et al., 2008). Urban waste as an alternative source of organic amendments therefore seems to present an important opportunity for improving crop production. However few studies have been conducted on urban-waste compost demand and farmers' attitudes in different countries, hence it has been difficult to compare my results with other studies conducted in different socioeconomic settings. In my thesis I found that the demand for urban-waste compost varied between different farmer groups (Chapter 2). Income, education and access to extension services explained the variation in compost demand. Farmers with better access to finance, education and extension services were able to understand the benefits of compost and were more interested in applying urban-waste compost on their farmlands than poor subsistence farmers. Low nutrient content (Getahun et al., 2012b; Hargreaves et al. 2008), contamination with heavy metals and sanitation were and remain major concerns around urban-waste compost, and these issues determined farmers' interest in the use of urban-waste compost. A small number of studies are available on the nutrient content and qualities of compost produced from urban waste, particularly in Africa (Getahun et al., 2012b). Even though the risks of heavy metals are not included in my thesis, they present one of the main concerns about urban-waste compost because contaminants (e.g. old batteries, plastics and metal scraps) are commonly found in urban waste. Despite high concern about heavy metal contamination, recent studies show that urban-waste compost can be applied without contamination of heavy metals as long as the relevant guidelines are 
followed (Lekfeldt et al., 2015). In many developing countries, however, national compost guidelines and standards to control compost quality do not exist. Source separation systems - sorting of different materials at their point of generation - are another option to reduce contamination and improve the efficiency of waste recycling. However, this system does not exist in many developing countries and hence municipalities should encourage and provide incentives to communities to sort different materials at their point of generation.

I noted that current policies such as the land tenure system are one of the main drivers preventing farmers from using urban-waste compost and intensifying their production systems. In Ethiopia, land is owned by the government and the transfer of land through long-term leases or sales and/or the use of land as collateral is legally prohibited. Moreover, rapid population growth and the expansion of cities put pressure on agricultural land, especially in urban and peri-urban farming systems. These circumstances cause insecure landownership and hence discourage farmers from investing in their farmlands (Chapter 2; Kassie et al., 2009). It is therefore essential to improve the existing policies, infrastructure and financial institutions to enable farmers to use urban-waste compost and other organic amendments (i.e. agricultural waste).

Decentralised and community-based composting enterprises are suggested to ensure the use of urban-waste compost as a soil amendment because large and centralised composting plants incur high operational, maintenance and transportation costs (Danso et al., 2008). Recently, a small number of small-scale composting enterprises have been set up, thereby creating jobs for young people and poor urban dwellers. The market linkage between compost producers and farmers, however, is still inadequate. Consequently, most enterprises are not profitable. Thus approaches that link up farmers with compost producers, with the assumption of long-term business relationships, should be identified. Furthermore, the government should subsidise the making and use of urban-waste compost. The involvement of governmental and private sectors is therefore crucial, and these institutions should work closely with compost producers, farmers and research institutes to (i) improve compost quality, (ii) ensure market linkages and (iii) provide financial and technical support for compost producers and farmers.

Currently, waste energy projects are being implemented in Sub-Saharan African countries with the aim of producing energy from municipal waste and using the byproducts as liquid fertiliser and/or compost (Hamad et al., 2014). Although these projects are not included in my thesis, the implementation of these projects is important for the execution of urban-waste composting because they improve the efficiency of waste collection and reduce the amount of waste dumped in landfill and/or waterbodies. The agronomic value of waste energy by-products is, however, very low in nutrient content, hence studies are needed to improve the agricultural importance of composts and/or fertilisers produced from these by-products. 


\section{Low-cost techniques to reduce $\mathrm{N}$ losses and mitigate GHG emissions during composting}

In Chapter 2 I indicated the need for urban-waste composting. However, challenges remain around how to produce nutrient-rich compost (Danso et al., 2008), reduce $\mathrm{N}$ losses (when starting with N-rich waste) and mitigate GHG emissions during urbanwaste composting (Nigussie et al., 2016) at low costs. Chapter 2 is helpful for understanding the socio-economic perspective of my project and provides the foundation for the next chapters of my thesis. In Chapters 3, 4 and 5 I discussed low-cost technologies that reduce nutrient (mainly N) losses and GHG emissions during urbanwaste composting.

\section{Vermicomposting}

Nitrogen losses during composting reduce the agronomic value of compost and contribute to greenhouse gas emissions. I found $\mathrm{N}$ losses of between $30 \%$ and $60 \%$ of the initial $\mathrm{N}$ content (Chapters 3 and 5), and such losses are comparable with earlier studies (Bernal et al., 2009; Steiner et al., 2010; Chowbury et al., 2014). The high variation in N losses was explained by the differences in the $\mathrm{N}$ content of the composting materials and the temperatures in the composting pile. Temperature influenced $\mathrm{N}$ losses from composting because ammonia emissions occur at high temperatures $\left(>45^{\circ} \mathrm{C}\right.$ ) (Pagans et al., 2006). Chapter 3 was therefore initiated to test the effectiveness of earthworm composting (i.e. vermicomposting) at reducing $\mathrm{N}$ losses and GHG emissions because it is a mesophilic process and earthworms influence $\mathrm{N}$ cycling. I demonstrated that vermicomposting reduced $\mathrm{N}$ losses and non- $\mathrm{CO}_{2} \mathrm{GHG}$ emissions $\left(\mathrm{N}_{2} \mathrm{O}\right.$ and $\left.\mathrm{CH}_{4}\right)$. Higher $\mathrm{N}$ losses in thermophilic composting were observed with substrates with a high nitrogen content, and the effectiveness of earthworms at reducing $\mathrm{N}$ losses was more pronounced with these substrates. Ammonia volatilisation explained the differences in $\mathrm{N}$ losses between the two composting methods (i.e. thermophilic composting and vermicomposting).

Different mechanisms explained the decrease in $\mathrm{N}$ losses during vermicomposting. The first obvious mechanism was the temperature effect. Ammonia volatilisation accounts for about 70\% of total N losses (Szanto et al., 2007; Chowdhury et al., 2014) and occurs at higher temperatures. In contrast, vermicomposting is a mesophilic process, hence high $\mathrm{NH}_{3}$ volatilisation was not expected. A second mechanism could be the lowering of $\mathrm{pH}$ in vermicomposting experiments (Chapters 3 and 4) compared with conventional composting because $\mathrm{NH}_{3}$ emission occurred more at a higher $\mathrm{pH}$. In agreement with my results, Wang et al. (2014) and Velasco-Velasco et al., (2011) reported low ammonia emissions during vermicomposting. Optimising the nitrogen contents of the composting materials (i.e. adjusting the $\mathrm{C}: \mathrm{N}$ ratio to between 25:1 and 30:1) has been recommended to minimise $N$ losses (Chowdhury et al., 2014). 
Addition of straw reduced $\mathrm{N}$ losses by $24 \%$ (Chapter 3), which is consistent with previous studies (Velasco-Velasco et al., 2011; Chowdhury et al., 2014). In Chapter 2, however, I demonstrated competing uses of crop residues (straw) for animal feed in smallholder farming systems. Hence, vermicomposting is a more practical and less expensive method to reduce $\mathrm{N}$ losses during composting compared to using crop residues. Chapter 5 and Chowdhury et al. (2014) showed that bulking materials (other than crop residues such as sawdust) could be used to reduce $\mathrm{N}$ losses from composting. However, these materials are expensive and not available in large quantities, particularly in countries such as Ethiopia. Techniques to control pH (Pagans et al., 2006) and the use of absorbents (i.e. active carbon, biochar and zeolite) (Steiner et al., 2010; Kahn et al., 2016) will also result in reduced $\mathrm{N}$ losses, but they are expensive and difficult to scale up to field conditions.

Vermicomposting decreased $\mathrm{N}_{2} \mathrm{O}$ emissions compared with thermophilic composting, but the effect of the earthworms' was affected by substrate quality (nitrogen content), earthworm abundance and feeding ratio (Chapters 3 and 4 ). In these chapters, I used different parameters to explain the effect of earthworms on $\mathrm{N}_{2} \mathrm{O}$ emissions because the existing literature is contradictory and requires clarification. In agreement with my findings, Chan et al. (2010) and Wang et al. (2014) found that earthworms reduce $\mathrm{N}_{2} \mathrm{O}$ emissions from composting. The obvious mechanisms for lower $\mathrm{N}_{2} \mathrm{O}$ emissions during vermicomposting are: (i) continuous turning of substrates by earthworms, which increases air circulation and entry of oxygen (Chapter 3; Chan et al., 2010) and (ii) earthworms accelerate the stabilisation of organic materials (i.e. low content of labile $\mathrm{C}$ for denitrifying bacteria during vermicomposting) (Chapter 4). In contrast to my findings, our unpublished data (De Mota et al., unpublished) show that continuous turning of piles by hand leads to lower $\mathrm{N}_{2} \mathrm{O}$ losses than with earthworms. Similarly, Lubbers et al. (2013) reported that earthworms induce $\mathrm{N}_{2} \mathrm{O}$ emissions from soils. Earthworm-induced $\mathrm{N}_{2} \mathrm{O}$ emissions are explained by high mineralisation and denitrification in the earthworm gut (Hobson et al., 2005). Substrate quality (mainly nitrogen and carbon content) is the key variable that should be considered when assessing the effect of earthworms on $\mathrm{N}_{2} \mathrm{O}$ emissions. Lubbers et al. (2013) found higher earthworm-induced $\mathrm{N}_{2} \mathrm{O}$ emissions from soils where $\mathrm{N}$ content and carbon content are lower (total nitrogen content of $<1.3 \mathrm{~g} \mathrm{~kg}^{-1}$ and carbon content of $<30 \mathrm{~g} \mathrm{~kg}^{-1}$ soil) compared with vermicomposting experiments (total nitrogen content of $14 \mathrm{~g} \mathrm{~kg}^{-1}$ and carbon content of $400-500 \mathrm{~g} \mathrm{~kg}^{-1}$ dry matter) (Chapter 3). Similarly, in our unpublished data (De Mota et al., unpublished), materials were used that underwent a longer precomposting period. It appears that the earthworm gut contributes a small amount to $\mathrm{N}_{2} \mathrm{O}$ emissions compared with the denitrification process taking place in the composting materials. Furthermore, the species used in my experiments (Eisenia fetida in Chapter 3 and a mixture of Eisenia fetida and Dendrobaena veneta in Chapter 5) were different from the earthworms used in soil experiments (Lumbricus rubellus) and/or species used by De 
Mota et al. (unpublished) (Dendrobaena veneta) (see Box 6.2). This difference could be another explanation for the observed variation because earthworms with different feeding strategies vary in terms of decomposition rates of substrate with which they are feeding (Lubbers et al., 2013). My results and earlier studies indicate that the earthworms' effect on $\mathrm{N}_{2} \mathrm{O}$ emissions are diverse and depend on the environment in which they live. The effects of earthworms on GHG emissions could be altered simply by manipulating variables such as substrate quality, earthworm density and feeding ratio. Hence it is essential to identify when and where earthworms are important for reducing $\mathrm{N}_{2} \mathrm{O}$ emissions.

In Chapters 3 and 5, I also noted that vermicomposting decreased $\mathrm{CH}_{4}$ emissions compared with conventional composting. In agreement with my findings, Luth et al. (2011) and Wang et al. (2014) reported a 40-65\% decrease in $\mathrm{CH}_{4}$ emissions during vermicomposting. The obvious mechanisms are: (i) earthworms increase air circulation by continuously turning the substrates, (ii) earthworms maintain substantially lower temperatures that result in reduced $\mathrm{CH}_{4}$ production compared to thermophilic composting because activities of methanogenic bacteria increase with temperature (Ermolaev et al., 2014) and (iii) high oxygen demand (and limited exchange with the surroundings) during the thermophilic phase creates anaerobic patches where most $\mathrm{CH}_{4}$ is produced ( $\mathrm{Vu}$ et al., 2014). In soils, however, both increases (Kammann et al., 2009) and decreases (Kernecker et al., 2015; Kim et al. 2011) of $\mathrm{CH}_{4}$ emissions in the presence of earthworms have been observed, but the underlying mechanisms are not known. The positive effect could be explained by earthworm casts possibly stimulating methanogenic activity (Depkat-Jakob et al., 2012) because casts constitute an anaerobic substrate due to the limited diffusion of oxygen into the casts. During vermicomposting, the substrates are rich in easily degradable materials, hence earthworm-induced $\mathrm{CH}_{4}$ emissions are unlikely to occur. Moreover, the earthworm species in the vermicomposting experiments and soil experiments were different. Hence, the results of vermicomposting experiments cannot be extrapolated to agricultural soils. In their meta-analysis, Lubbers et al., (2013) excluded $\mathrm{CH}_{4}$ while estimating the earthworm effect on GHG budget from agroecosystems. However, my thesis and other studies on soil (Kammann et al., 2009) indicate the need for further study into the role of earthworms on $\mathrm{CH}_{4}$ emissions from agricultural practices. 


\section{BOX 6.2. Types of earthworms}

Ecologists divide earthworms into three functional groups on the basis of their feeding and burrowing behaviour, namely: (i) epigeic species that live within the few centimetres of the soil-litter interface, feed on undecomposed litter and do not make burrows, (ii) endogeic species that feed on soil and associated organic matter and live in non-permanent branching burrows below the soil surface, and (iii) anecic species that feed on the surface litter and pull it into the soil in permanent burrows.

Earthworms used for vermicomposting are epigeic species, but not all epigeic species are composting worms. There are an estimated 1,800 species of earthworm worldwide, but only a few of these are used for vermicomposting. The species currently commonly used in tropical and sub-tropical countries are Eisenia fetida, Dendrobaena veneta and Eudrilus eugeniae. All of these worms are prolific feeders and can eat up to half of their weight per day. Even though theses worms are used for vermicomposting, they vary in terms of substrate affinity, tolerance to external environments (temperature, $\mathrm{pH}, \mathrm{EC}$ ), biomass and rate of production. Eisenia fetida, for example, can feed on a wide range of organic waste and survive in temperatures of between $10{ }^{\circ} \mathrm{C}$ to $35{ }^{\circ} \mathrm{C}$. In contrast, Dendrobaena veneta is sensitive to high temperatures and its production is low in substrates such as manure.

The decomposition and mineralisation processes differ between earthworm species (Postma-Blaauw et al., 2006). As a result, the earthworms' effect on N cycling and GHG emissions vary between earthworm species. For instance, Lubbers et al. (2013) indicated that earthworm species influence GHG emissions from soils differently.

In all the experiments, despite variations in substrate quality ( $\mathrm{C}: \mathrm{N}$ ratio), earthworm abundance and feeding ratio, $\mathrm{CO}_{2}$ emissions were higher from vermicomposting than from thermophilic composting (Chapters 3 and 4). Similarly, Chan et al. (2010) found higher $\mathrm{CO}_{2}$ production from vermicomposting than from conventional composting. Higher $\mathrm{CO}_{2}$ evolution, which appears to suggest a greater contribution to GHG emissions by earthworms, in fact indicates a greater degree of stabilisation of the compost (Bernal et al., 2009; Wichuk and McCartney, 2010). Such results therefore imply that vermicompost has a greater degree of stability than conventional compost. Similarly in Chapter 5, I confirmed the higher degree of stabilisation during vermicomposting using additional parameters such as dissolved organic carbon (DOC) concentration, the composition of DOC in different fractions and $\mathrm{NH}_{4}{ }^{+}: \mathrm{NO}_{3}^{-}$ratio (Chapter 5). We however noted that compost stability indices such as total DOC content and $\mathrm{NH}_{4}{ }^{+}: \mathrm{NO}_{3}{ }^{-}$ratio 
could yield different results. The $\mathrm{NH}_{4}{ }^{+}: \mathrm{NO}_{3}{ }^{-}$ratio depends on the substrate quality while the DOC concentration is often reported without correcting for non-organic (mineral) components of composting material. Indices such as a $\mathrm{C}: \mathrm{N}$ ratio and temperature are also recommended as indicators of compost maturity (Khan et al., 2014), however, theses indices also depend on substrate quality. The combined use of multiple indices is therefore suggested to assess compost stability. Future studies are also needed to develop a more reliable compost maturity indicator.

Since $\mathrm{CO}_{2}$ evolution indicates a greater degree of stabilisation of compost, only $\mathrm{N}_{2} \mathrm{O}$ and $\mathrm{CH}_{4}$ emissions were used in Chapter 3 to estimate the GHG budget of the two composting methods (vermicomposting and thermophilic composting). The rationale for excluding $\mathrm{CO}_{2}$ emissions from the total GHG budget was that the less stable composts produce more $\mathrm{CO}_{2}$ during soil application (Ngo et al., 2013; Sierra et al., 2013), hence the total $\mathrm{CO}_{2}$ emissions would eventually converge to the same value for all composts. When $\mathrm{CO}_{2}$ was excluded, vermicomposting reduced total GHG emissions by $26-37 \%$ (Chapter 3). The relative contribution of $\mathrm{N}_{2} \mathrm{O}$ and $\mathrm{CH}_{4}$ emissions to total GHG budget depended on substrate quality. $\mathrm{CH}_{4}$ emissions dominated the GHG budget when the substrates contained a high amount of easily degradable $C$ (i.e. vegetable waste), while $\mathrm{N}_{2} \mathrm{O}$ emissions dominated with substrates containing high $\mathrm{NO}_{3}{ }^{-}$(i.e. manure).

Even though vermicomposting produces a high-quality compost (Lazcano et al., 2008; Chapter 3; Chapter 5), vermicomposting is not common practice in many developing countries. Promotion of vermicomposting technology is still needed, particularly in developing countries such as Ethiopia. Active participation of institutions is a key to integrating earthworms into the existing waste management strategy and closing rural-urban nutrient loops. Further technical and socioeconomic research is needed to optimise the vermicomposting process. For instance, local earthworm species should be tested to identify whether they could be used for vermicomposting. Composting worms such as Eisenia fetida, Dendrobaena veneta and Eudrilus eugeniae should be introduced. Pathogens such as E. coli and Salmonella are commonly found in urban waste, hence temperatures above $50{ }^{\circ} \mathrm{C}$ for a minimum of three days are required to destroy these pathogens (Ryckeboer et al., 2003). Sanitation could therefore be the main concern with vermicomposting of urban waste, but some studies indicate the effectiveness of vermicomposting at eradicating pathogens (Rodríguez-Canché et al., 2010; Edwards et al., 2011). However, more studies are still required to understand the mechanisms of how earthworms eradicate pathogens from the compost pile. Precomposting prior to vermicomposting could be another solution to eradicating pathogens from vermicompost (Wang et al., 2014), however significant $\mathrm{N}$ losses could occur during pre-composting. More research is therefore needed to optimise vermicomposting technology so that the balance between $\mathrm{N}$ losses and sanitation is maintained. In my thesis, I used kitchen waste that was not contaminated with heavy metals. In practice, urban waste contains heavy metals, hence further studies are 
required to determine the effect of vermicomposting on the bioavailability of heavy metals during urban-waste composting.

\section{Delayed addition of N-rich substrate}

Composting of nitrogen-poor materials such as urban waste with manure is commonly used to increase the $\mathrm{N}$ concentration of compost (Lhadi et al., 2006; Rizzo et al., 2015). During this composting practice, however, we observed about $60 \% \mathrm{~N}$ losses (Nigussie et al., 2016b), which is comparable with the losses reported in earlier studies (Bernal et al., 2009; Steiner et al., 2010). The high $\mathrm{N}$ losses were caused by the coexistence of a thermophilic phase $\left(>45{ }^{\circ} \mathrm{C}\right)$ with high $\mathrm{NH}_{4}{ }^{+}$concentrations in the manure, which generated optimal conditions for ammonia volatilisation. In Chapter 5, I demonstrated that the addition of $\mathrm{N}$-rich substrate (i.e. poultry manure) after the thermophilic phase reduced $\mathrm{N}$ losses by 20\%. My results are in agreement with Bryndum (2014) who reported a $33 \%$ reduction in $\mathrm{N}$ losses due to delayed addition. When $\mathrm{N}$-rich substrate was applied after the thermophilic phase, most added $\mathrm{N}$ was exposed to low temperatures $\left(<30{ }^{\circ} \mathrm{C}\right)$, which were less conducive to ammonia volatilisation. The majority of $\mathrm{N}$ was prone to $\mathrm{NH}_{3}$ volatilisation when all the $\mathrm{N}$-rich substrate was added at the beginning. Dresbøll and Thorup-Kristensen (2005) did not observe a significant effect of delayed addition of $\mathrm{N}$-rich substrate (i.e. clover) on $\mathrm{N}$ losses. The differences in $\mathrm{NH}_{4}{ }^{+}$ concentration between these materials (i.e. manure vs. clover) may explain the differential effect. Poultry manure contains high levels of $\mathrm{NH}_{4}{ }^{+}$, but clover contains mainly organic N. As a result, the effect of delayed addition is smaller because nitrogen has to be mineralised before it can volatilise. Moreover, the thermophilic phase lasted for more than three weeks in my study, but Dresbøll and Thorup-Kristensen (2005) observed a thermophilic phase that lasted for two weeks. As a result this and the larger fraction of organic $\mathrm{N}, \mathrm{NH}_{3}$ volatilisation was higher in my study than in their experiment.

High temperatures reduce $\mathrm{N}_{2} \mathrm{O}$ emissions because nitrifying and denitrifying bacteria are mesophilic (Vu et al., 2015). Consequently, high $\mathrm{N}_{2} \mathrm{O}$ production occurs after the thermophilic phase (Hao et al., 2004). Addition of N-rich substrate after the thermophilic phase therefore increased the accessibility of inorganic $\mathrm{N}\left(\mathrm{NH}_{4}^{+}\right.$and $\left.\mathrm{NO}_{3}{ }^{-}\right)$ for nitrifying and denitrifying bacteria, subsequently increasing $\mathrm{N}_{2} \mathrm{O}$ production. At the same time, delayed addition decreased $\mathrm{CH}_{4}$ emissions as a result of (i) the absence of high temperatures in conjunction with reduced available $\mathrm{C}$ and $\mathrm{N}$ for the methanogens and (ii) higher methane oxidation due to the similarity between enzymes involved in methane and ammonium oxidation (Wei et al., 2016).

The main concern with delayed addition of N-rich substrate is whether the product is stable and free from pathogens and weed seeds because substrate added later has less time to decompose. In addition to sanitation concerns, compost stability is crucial because the application of unstable compost can impede crop growth (Wichuk 
and McCartney, 2010). In my thesis, I demonstrate that delayed addition resulted in compost that was as stable and effective at completely eradicating weed seeds as traditional composting. Furthermore, the germination test confirmed that the composts produced by delayed addition were as mature as by the traditional composting method. My results indicated that farmers could reduce $\mathrm{N}$ losses and produce high-agronomicvalue compost simply by manipulating the timing of the addition of $\mathrm{N}$-rich substrate. I manipulated the timing of the addition of N-rich substrate but in practice, however, different qualities of materials are added at different times during composting. Further studies are therefore needed to determine the effect of timing of addition of different quality materials on the composting process

In Chapter 2, I showed that manure is used mainly for fuel in smallholder farming systems; hence it is plausible to challenge the applicability of delayed addition in smallholder farming systems. In Chapter 5, I deliberately used poultry manure because it has no or little competitive uses in Ethiopia. Furthermore, the management of poultry manure presents a challenge for many poultry production systems. The use of this $\mathrm{N}$-rich substrate together with urban waste could therefore be one strategy for increasing the agronomic value of urban-waste compost. A link between poultry producers (or livestock producers) and urban-waste compost producers should be established in order to utilise the manure for urban-waste composting.

\section{Future research directions}

Efforts have been made throughout this thesis to illustrate possibilities for closing urbanrural nutrient cycles through urban-waste composting. However research is still needed (1) to understand the socio-economic perspective of urban-waste composting and (2) to improve the nutrient content of urban-waste compost using low-cost technologies. Furthermore, I encountered limitations when conducting the experiments that are listed in this thesis. For instance, simple econometric models and a small group of farmers were used to estimate the current uses of agricultural waste and compost demand. Therefore, it is recommended that in the future a greater diversity of farming systems and a wider variety of econometrics approaches be used when assessing the pressure on agricultural waste and examining the demand for urban-waste compost.

My composting experiments were conducted in small-scale reactors and the experiments (particularly vermicomposting) were conducted for less than 60 days. Care should therefore be taken when extrapolating the results to large-scale composting systems. Most of my experiments do not explain the mechanisms involved in how different treatments cause $\mathrm{N}$ losses and GHG emissions. In addition to this, some important parameters such as $\mathrm{NH}_{3}$ were not measured directly due to methodological challenges. I showed that earthworms reduce GHG emissions from composting; however exactly how this happened was not studied in any detail with regard to microbial 
ecology and physiology. Furthermore, how delayed addition influences $\mathrm{N}_{2} \mathrm{O}$ and $\mathrm{CH}_{4}$ emissions needs further clarification. For instance, I observed the second thermophilic period during delayed addition, but the advantage and/ or disadvantage of this phase need further investigation.

Based on the results of my thesis, I recommend the following technical and socioeconomic research areas:

1. How crop residues and animal manure can fulfil the future demand for both fuel/feed and soil amendment in smallholder farmers still presents a challenge and needs prompt solutions

2. Not all compost worms are the same, hence the effect of different earthworm species on N losses, GHG emissions and composting process should be studied

3. The link between compost stability, dissolved organic carbon (DOC) and DOC composition needs to be better established. Furthermore, the earthworms' effect on DOC composition should be studied (i.e. earthworm abundance, earthworm species and substrate quality)

4. The effect of the timing of N-rich substrate addition on GHG emissions is a new concept and future studies are recommended to understand the mechanisms.

5. Studies that address the socioeconomic and cultural issues of urban-waste compost are needed, such as (i) a cost-benefit analysis of vermicomposting since continuous addition of substrate for earthworms might be labour intensive, (ii) how institutions should be organised to encourage their participation in urban-waste composting.

6. Upscaling of vermicomposting and delayed addition of $\mathrm{N}$-rich substrate is needed

\section{Conclusions}

The competition for agricultural waste between fuel, animal feed and soil amendments is a major reason behind the limited use of organic amendments to soils in smallholder farming systems. Hence technologies that fulfil the demands for feed, fuel and soil amendments are required. One single technology would not provide the solution; instead combinations of different technologies are needed. One option could be to use urban-waste compost as an alternative soil amendment, particularly in (peri-)urban farming systems. However, this technology would not be achieved without the involvement of different institutions because considerable investment is required before urban-waste could be utilised as a soil amendment. Many socioeconomic drivers (i.e. access to extension services and land tenure systems) influence the adoption of urbanwaste compost. It is therefore essential to improve existing policies, infrastructures and financial institutions to enable farmers to use urban-waste compost.

Urban-waste compost has a low nutrient content, and high $\mathrm{N}$ losses and GHG emissions occur during the composting of N-rich materials. Efforts should be made to 
increase the agronomic value of urban-waste compost and reduce GHG emissions using low-cost technologies. Vermicomposting is one strategy for reducing $\mathrm{N}$ losses and GHG emissions from small-scale composting. The effects of vermicomposting, however, depend on substrate quality (i.e. nitrogen content) and other factors (moisture, earthworm species and earthworm density). Hence, optimum management practices should be established to achieve the desired objectives of vermicomposting. Delayed addition of nitrogen-rich substrate is another option to reduce $\mathrm{N}$ losses from urban-waste composting without having a significant effect on total greenhouse gas emissions or compost stability. Although vermicomposting and delayed additions of nutrient-rich substrate are effective in producing high-quality compost, the promotion of these technologies and the creation of conducive conditions for their use by smallholder farmers still present major challenges that require the input of natural and social scientists, policy makers and farmers. 


\section{References}

Abbasi SA, Nayeem-Shah M, Abbasi T (2015). Vermicomposting of phytomass: limitations of the past approaches and the emerging directions. Journal of Cleaner Production. 47, 70-75.

Abdulkadir A, Dossa LH, Lompo DJP, Abdu N, van Keulen H (2012). Characterization of urban and peri-urban agroecosystems in three West African cities. International Journal of Agricultural Sustainability. 10 (4), 289-314.

Abdulkadir A, Leffelaar PA, Agbenin JO, Giller KE (2013). Nutrient flows and balances in urban and peri-urban agroecosystems of Kano, Nigeria. Nutrient Cycling in Agroecosystems. 95(2), 231-254.

Aira M, Domínguez J (2008). Optimizing vermicomposting of animal wastes: effects of manure application on C loss and microbial stabilisation. Journal of Environmental Management. 88, 1525 1529.

Amsalu A, Stroosnijder L, de Graaff J (2007). Long-term dynamics in land resource use and the driving forces in the Beressa watershed, highlands of Ethiopia. Journal of Environmental Management. 83, $448-459$.

Andersen JK, Boldrin A, Samuelsson J, Christensen TH, Scheutz C (2010). Quantification of greenhouse gas emissions from windrow composting of garden waste. Journal of Environmental Quality. 39(2), 713-24.

Aslam, DN, Vander-Gheynst JS (2008). Predicting phytotoxicity of compost-amended soil from compost stability measurements. Environmental Enginering and Science. 25, 72-81.

Awasthi MK, Wang Q, Huang H, Ren X, Lahori AH, Mahar A, Ali A, Shen F, Li R, Zhang Z (2016). Influence of zeolite and lime as additives on greenhouse gas emissions and maturity evolution during sewage sludge composting. Bioresource Technology. 216, 172-181.

Baudron F, Jaleta M, Okitoi O, Tegegn A (2014). Conservation agriculture in African mixed croplivestock systems: Conservation agriculture in African mixed crop-livestock systems: Expanding the niche. Agriculture, Ecosystem and Environment 187:171-182.

Bernad-Beltrán D, Simó A, Bovea MD (2014). Attitude towards the incorporation of the selective collection of biowaste in a municipal solid waste management system. A case study. Waste Management. 34, 2434-2444.

Bernal MP, Alburquerque JA, Moral R (2009). Composting of animal manures and chemical criteria for compost maturity assessment. A review. Bioresource Technology. 100, 5444- 5453.

Boulter-Bitzer JI, Trevors JT, Boland GJ (2006). A polyphasic approach for assessing maturity and stability in compost intended for suppression of plant pathogens. Applied Soil Ecology. 34, 65-81.

Bryndum S (2014). Biotransformation of organic waste into high quality fertilizer: Potentials and limitations for compost process optimization and nutrient recycling. PhD dissertation, Copenhagen University, Denmark, Pp 101.

Bustamante MA, Restrepo AP, Alburquerque JA, Pérez-Murcia MD, Paredes C, Moral R, Bernal MP (2013). Recycling of anaerobic digestates by composting: effect of the bulking agent used. Journal of Cleaner Production. 47, 61-69.

Chan YC, Sinha RK, Wang W (2011). Emission of greenhouse gases from home aerobic composting, anaerobic digestion and vermicomposting of household wastes in Brisbane, Australia. Waste Management and Research. 29, 540-548.

Chan MT, Selvam A, Wong JWC (2016). Reducing nitrogen loss and salinity during 'struvite' food waste composting by zeolite amendment. Bioresource Technology. 200, 838-844. 
Chen C, Whalen JK, Guo X (2014). Earthworms reduce soil nitrous oxide emissions during drying and rewetting cycles. Soil Biology and Biochemistry. 68, $117-124$.

Chowdhury MA, de Neergaard A, Jensen LS (2014). Potential of aeration flow rate and bio-char addition to reduce greenhouse gas and ammonia emissions during manure composting. Chemosphere. 97, 16-25.

Condon PM, Mullinix K, Fallick A, Harcourt M (2010). Agriculture on the edge: Strategies to abate urban encroachment onto agricultural lands by promoting viable human-scale agriculture as an integral element of urbanization, in: Pearson, C.J., Pilgrim, S., Pretty J., (Eds.), Urban agriculture: Diverse activities and benefits for city society. International Journal Agricultural Sustainability. 8 (162), 104-115.

Cook KL, Ritchey EL, Loughrin JH, Haley M, Sistani KR, Bolster CH (2015). Effect of turning frequency and season on composting materials from swine high-rise facilities. Waste Management. 39, 86-95.

Czepiel P, Douglas E, Harriss R, Crill P (1996). Measurements of $\mathrm{N}_{2} \mathrm{O}$ from composted organic wastes. Environmental Science Technology. 30, 2519-2525.

Danso G, Drechsel P, Fialor S, Giordano M (2006). Estimating the demand for municipal waste compost via farmers' willingness to-pay in Ghana. Waste Management. 26(12),1400-1409.

Damte A, Koch SF, Mekonnen A (2012). Coping with Fuel wood Scarcity Household Responses in Rural Ethiopia: Environment for Development: Discussion Paper Series 12-01.

De Bon H (2001). Urban and peri urban horticulture in Africa and Asia: Characterization of the systems and issues of sustainability. Annotated Bibliography on Urban Agriculture. Wageningen, The Netherlands.

De Mota ACS, Nigussie A., Kuyper TW. Delayed addition of N-rich substrate affects greenhouse gas emissions during composting. (unpublished)

Depkat-Jakob PS, Hunger S, Schulz K, Brown GG, Tsai SM, Drake HL (2012). Emission of methane by Eudrilus eugeniae and other earthworms from Brazil. Applied Environmental Microbiology. 78, 3014-3019.

Dercon S, Christiaensen L (2011). Consumption Risk, Technology Adoption, and Poverty Traps: Evidence from Ethiopia. Journal of Development Economics 96:159-173.

Dias BO, Silva CA, Higashikawa FS, Roig A, Sánchez-Monedero MA (2010). Use of biochar as bulking agent for the composting of poultry manure: Effect on organic matter degradation and humification. Bioresource Technology. 101, 1239-1246.

Diogo RVC, Buerkert A, Schlecht E (2010). Horizontal nutrient fluxes and food safety in urban and peri-urban vegetable and millet cultivation of Niamey, Niger. Nutrient cycle in Agroecosystems. 87,81-102.

Dossa LH, Abdulkadir A, Amadou H, Sangare S, Schlecht E (2011). Exploring the diversity of urban and peri-urban agricultural systems in Sudano-Sahelian West Africa: An attempt towards a regional typology. Landscape and urban planning. 102, 197-206.

Drechsel P, Keraita B, Amoah P, Abaidoo RC, Raschid-Sally L, Bahri A (2008). Reducing health risks from wastewater use in urban and peri-urban sub- Saharan Africa: applying the 2006 WHO guidelines. Water Science Technology. 57, 1461-1466.

Dresbøll DB. Thorup-Kristensen K (2005). Delayed nutrient application affects mineralisation rate during composting of plant residues. Bioresource Technology. 96(10), 1093-101. 
Edwards CA (2011). Human pathogen reduction during vermicomposting. In: Edwards, C.A., Arancon, N.Q., Sherman, R. (Eds.), Vermiculture Technology: Earthworms, Organic Wastes and Environmental Management. CRC Press, Boca Raton, pp. 249-261.

Eklind Y, Sundberg C, Smars S, Steger K, Sundh I, Kirchmann H, Joensson H (2007). Carbon turnover and ammonia emissions during composting of biowaste at different temperatures. Journal of Environmental Quality 36, 1512-1520.

Ermolaev E, Sundberg C, Pell M, Jönsson H (2014). Greenhouse gas emissions from home composting in practice. Bioresource Technology. 151, 174-182.

Folefack A ( 2005). The Use of Compost from Household Waste in Agriculture: Economic and Environmental Analysis in Cameroon, in: Doppler W., Bauer S. (Eds.), Farming \& Rural Systems Economics. Germany.

García-Gil JC, Ceppi S, Velasca M, Polo A, Senesi N (2004). Long-term effects of amendment with municipal solid waste compost on the elemental and acid functional group composition and pH-buffer capacity of soil humic acid. Geoderma 121, 135-142.

García-Marco S, Ravell SR, Chadwi D, Vallejo A, Gregory AS, Cárdena LM (2014). Ranking factors affecting emissions of GHG from incubated agricultural soils. European Journal of Soil Science. 65, 573-583.

Getahun T, Mengistie E, Haddis A, Wasie F, Alemayehu E, Dadi D, Van Gerven T, Van der Bruggen B (2012a). Municipal solid waste generation in growing urban areas in Africa: current practices and relation to socioeconomic factors in Jimma, Ethiopia. Environmental Monitoring and Assessment. 184(10), 6337-45.

Getahun T, Nigussie A, Entele T, Van Gerven T, Van der Bruggen B (2012b). Effect of turning frequencies on composting biodegradable municipal solid waste quality. Resource, Conservation E Recycling. 65, 79-84.

Getnet M., Van Ittersum M., Hengsdijk H., Descheemaeker K (2016). Yield gaps and resource use across farming zones in the central Rift Valley of Ethiopia. Experimental Agriculture. 52 (4), 493 517.

Gittleman M (2009). Urban expansion in Addis Ababa: Effects of the decline of urban agriculture on livelihood and food security. Tufts University. Presented at the United Nations 17th Commission on Sustainable Development.

Guerrero LA, Maas G, Hogland W (2013). Solid waste management challenges for cities in developing countries. Waste Management. 33, 220-232.

Gujarati DN (1995). Basic Econometrics, 3rd Edition. McGraw-Hill, Inc. USA.

Haileselassie A, Priess JA, Veldkamp E, Lesschen JP (2006). Smallholders' soil fertility management in the central highlands of Ethiopia: Implications for nutrient stocks, balances and sustainability of agroecosystems. Nutrient Cycling in Agroecosystems. 75 (3), 135-146.

Hanc A, Dreslova M (2016). Effect of composting and vermicomposting on properties of particle size fractions. Bioresource Technology. 217, 186-189.

Hamad TA, Agll AA, Hamad YM, Sheffield JW (2014). Solid waste as renewable source of energy: current and future possibility in Libya. Case Studies in Thermal Engineering. 4, 144-152.

Hao X, Chang C, Larney FJ (2004). Carbon, Nitrogen Balances and Greenhouse Gas Emission during Cattle Feedlot Manure Composting. Journal of Environmental Quality. 33, 37-44.

Hao X, Larney FJ, Chang C, Travis GR, Nichol CK, Bre E (2005). The Effect of Phosphogypsum on Greenhouse Gas Emissions during Cattle Manure Composting. Journal of Environmental Quality. $34,774-781$. 
Hargreaves JC, Adl MS, Warman PR (2008). A review of the use of composted municipal solid waste in agriculture. Agriculture, Ecosystems \& Environment. 123, 1-14.

Hobson AM, Frederickson J, Dise NB (2005). CH4 and N2O from mechanically turned windrow and vermicomposting systems following in-vessel pre-treatment. Waste Management. 25, 345-352.

Hou X, Wang X, Li R, Jia Z, Liang L, Wang J, Nie J, Chen X, Wang Z (2011). Effects of different manure application rates on soil properties, nutrient use, and crop yield during dryland maize farming. Soil Research. 50(6), 507-514.

IPCC (2013). The Physical Science Basis. Contribution of Working Group I to the Fourth Assessment Report of the Intergovernmental Panel on Climate Change [Solomon, S., D. Qin, M. Manning, Z. Chen, M. Marquis, K.B. Averyt, M. Tignor and H.L. Miller (eds.)]. Cambridge University Press, Cambridge, United Kingdom and New York, NY, USA, 996 pp.

Israel GD (1992). Determining Sample Size. University of Florida, USA.

Jaleta M, Kassie M, Erenstein O (2014). Determinants of maize stover utilization as feed, fuel and soil amendment in mixed crop livestock systems, Ethiopia. Agricultural Systems. 134, 17-23.

Jiang T, Schuchardt F, Li G, Guo R, Zhao Y (2011). Effect of C/N ratio, aeration rate and moisture content on ammonia and greenhouse gas emission during the composting. Journal of Environmental Science. 23(10), 1754-60.

Kammann C, Hepp S, Lenhart K, Müller C (2009). Stimulation of methane consumption by endogenous CH4 production in aerobic grassland soil. Soil Biology and Biochemistry. 41, 622-629.

Kassie M, Zikhali P, Manjur K, Edwards S (2009). Adoption of Organic Farming Techniques: Evidence from a Semi-Arid Region of Ethiopia. Environment for Development Discussion Paper Series 09-01.

Kasozi A, von Blottnitz H (2010). Solid Waste Management in Nairobi: A Situation Analysis, Technical Document accompanying the Integrated Solid Waste Management Plan, Nairobi, Kenya Pp 59.

Kernecker M, Whalen JK, Bradley RL (2015). Endogeic earthworms lower net methane production in saturated riparian soils. Biology and fertility of soil. 51, 271-275.

Khai NM, Ha PQ, Öborn I (2007). Nutrient flows in small-scale peri-urban vegetable farming systems in Southeast Asia: A case study in Hanoi. Agriculture, Ecosystems and Environment. 122, 192-202.

Khan N, Clark I, Sánchez-Monedero MA, Shea S, Meier S, Qi F, Kookana RS, Bolan N (2016). Physical and chemical properties of biochars co-composted with biowastes and incubated with a chicken litter compost. Chemosphere. 142, 14-23.

Kim TG, Moon KE, Lee EH, Choi SA, Cho KS (2011). Assessing effects of earthworm cast on methanotrophic community in a soil biocover by concurrent use of microarray and quantitative real-time PCR. Applied Soil Ecology. 50, 52-55.

Klotzbücher T, Kaiser K, Guggenberger G, Gatzek C, Kalbitz K (2011). A new conceptual model for the fate of lignin in decomposing plant litter. Ecology. 92(5), 1052-1062.

Lazcano C, Gómez-Brandón M, Domínguez J (2008). Comparison of the effectiveness of composting and vermicomposting for the biological stabilization of cattle manure. Chemosphere. 72, 10131019.

Lekfeldt JDS (2015). Urban waste effects on soil quality- results from the CRUCIAL field trial. PhD dissertation. University of Copenhagen, Denmark. Pp 105-132.

Lhadi EK, Tazi H, Aylaj M, Genevini PL, Adani F (2006). Organic matter evolution during cocomposting of the organic fraction of municipal waste and poultry manure. Bioresource Technology. 97, 2117-2123. 
Lim SL, Lee LH, Wu TY (2016). Sustainability of using composting and vermicomposting technologies for organic solid waste biotransformation: recent overview, greenhouse gases emissions and economic analysis. Journal of Cleaner Production. 111, 262-278.

Lleó T, Albacete E, Barrena R, Font X, Artola A, Sánchez A (2013). Home and vermicomposting as sustainable options for biowaste management. Journal of Cleaner Production. 47, 70-75.

Lubbers IM, van Groenigen KJ, Fonte SJ, Six J, Brussaard L, van Groenigen JW (2013). Greenhouse gas emissions from soils increased by earthworms. Nature Climate Change 3. 187-194.

Luth RP, Germain P, Lecomte M, Landrain B, Li Y, Cluzeau D (2011). Earthworm effects on gaseous emissions during vermifiltration of pig fresh slurry. Bioresource Technology. 102, 3679-3686.

Ly P, Jensen LS, Bruun TB, de Neergaard A (2013). Methane $\left(\mathrm{CH}_{4}\right)$ and nitrous oxide $\left(\mathrm{N}_{2} \mathrm{O}\right)$ emissions from the system of rice intensification (SRI) under a rain-fed lowland rice ecosystem in Cambodia. Nutrient Cycling in Agroecosystems. 97, 13-27.

Mann M., Warner J (2015). Ethiopian wheat yield and yield gap estimation: A small area integrated data approach. Addis Ababa, Ethiopia: International Food Policy Research Institute (IFPRI. http://ebrary.ifpri.org/cdm/ref/collection/p15738coll2/id/129170

Marshall R, Farahbakhsh K (2013). Systems approaches to integrated solid waste management in developing countries. Waste Management. 33(4), 988-1003.

Mary N, Dannie R, Nancy K, Kuria G, Stephen K, Sammy C, Will F (2010). Recycling of nutrients from organic wastes in Kenya's Capital City. African urban harvest, in: Gorden, P., Nancy, K., Diana, L., (Eds.), African urban harvest. pp 193-212.

Mekonnen A, Köhlin G (2009). Biomass fuel consumption and dung use as manure- evidence from rural households in the Amhara region of Ethiopia. Working papers in Economics: No 394. University of Gothenburg, Sweden.

Mengistu T (2013). Urban Agriculture: Challenges and opportunities in Addis Ababa City. MSc Dissertation. Ethiopian civil service University, Ethiopia.

Messer N, Townsley P (2003). Local institutions and livelihoods: Guidelines for analysis. Rural development division. FAO Rome, Italy.

Munroe G (2007). Manual of On-Farm Vermicomposting and Vermiculture, Organic Agriculture Centre of Canada Pp 56.

Ndegwa PM, Thompson SA, Das KC (2000). Effects of stocking density and feeding rate on vermicomposting of biosolids. Bioresource Technology. 71, 5-12.

Negassa W, Gebrekidan H, Friesen DK (2005). Integrated Use of Farmyard Manure and NP fertilizers for Maize on Farmers' Fields. Journal of Agriculture and Rural Development in the Tropics and Subtropics 106 (2), 131-141.

Ngo PT, Rumpel C, Ngo QA, Alexis M, Vargas GV, Gil M, Dang DK, Jouquet P (2013). Biological and chemical reactivity and phosphorus forms of buffalo manure compost, vermicompost and their mixture with biochar. Bioresource Technology. 148, 401-407.

Nigussie A, Kuyper T, de Neergaard A (2015). Agricultural waste utilisation strategies and demand for urban waste compost: Evidence from smallholder farmers in Ethiopia. Waste Management. 44, 82-93. [Chapter 2]

Nigussie A, Kuyper TW, Bruun S, de Neergaard A (2016a). Vermicomposting as a technology for reducing nitrogen losses and greenhouse gas emissions from small-scale composting. Journal of Cleaner Production. 136, 429-439. [Chapter 3] 
Nigussie A, Kuyper TW, Bruun S, de Neergaard A (2016b). Delayed addition of nitrogen-rich substrates during composting of municipal waste: Effects on nitrogen loss, greenhouse gas emissions and compost stability. Chemosphere. In press [Chapter 4]

Pagans E, Barrena R, Font X, Sánchez A (2006). Ammonia emissions from the composting of different organic wastes, Dependency on process temperature. Chemosphere. 62, 1534-1542.

Pan X, Song W, Zhang D (2010). Earthworms (Eisenia foetida, Savigny) mucus as complexing ligand for imidacloprid. Biology and Fertility of Soils. 46, 845-850.

Pasquini MW, Weinberger K, Assogba-Komlan F, Kouame C, Akpologan F, Djidji H (2010). Characterizing urban and peri-urban production systems for African indigenous vegetables in four cities in Benin and Côte d'Ivoire. Paper presented at International Symposium on urban and peri-urban horticulture in the century of cities. 5-9 December, 2010, Dakar, Senegal.

Peltre C, Nyord T, Bruun S, Jensen LS, Magid J (2015). Repeated soil application of organic waste amendments reduces draught force and fuel consumption for soil tillage. Agriculture, Ecosystems E Environment. 211, 94-101.

Poulsen PHB, Magid J, Luxhøi J, de Neergaard A (2013). Effects of fertilization with urban and agricultural organic wastes in a field trial - Waste imprint on soil microbial activity. Soil Biology and Biochemistry. 57, 794-802.

Regassa N, Sundaraa RD, Seboka BB (2011). Challenges and opportunities in municipal solid waste management: 710 The case of Addis Ababa city, central Ethiopia. Journal of Human Ecology. 33(3), 179-190.

Rimhanen K, Kahiluoto H (2014). Management of harvested C in smallholder mixed farming in Ethiopia. Agricultural Systems. 130, 13-22.

Rizzo PF, Torre VD, Riera NI, Crespo D, Barrena R, Sa'nchez A (2015). Co-composting of poultry manure with other agricultural wastes: process performance and compost horticultural use. Journal of Material Cycles and Waste Management. 17, 42-50.

Rodríguez-Canché LG, Cardoso VL, Maldonado-Montiel T, Martínez SM (2010). Pathogen reduction in septic tank sludge through vermicomposting using Eisenia fetida. Bioresource Technology. 101, 3548-3553.

Ryckeboer J, Mergaert J, Vaes K, Klammer S, de Clercq D, Coosemans J, Insam H, Swings J (2003). A survey of bacteria and fungi occurring during composting and self-heating processes. Annal Microbiology. 53, 349-410.

Santos A, Bustamante MA, Tortosa G, Moral R, Bernal MP (2016). Gaseous emissions and process development during composting of pig slurry: the influence of the proportion of cotton gin waste. Journal of Cleaner Production. 112, 81-90.

Scarlat N, Martinov M, Dallemand JF (2010). Assessment of the availability of agricultural crop residues in the European Union: Potential and limitations for bioenergy use. Waste Management 30, 1889-1897.

Schott ABS, Wenzel H, Jansen JC (2016). Identification of decisive factors for greenhouse gas emissions in comparative life cycle assessments of food waste management - an analytical review. Journal of Cleaner Production. 119, 13-24.

Shen Y, Ren L, Li G, Chen T, Guo R (2011). Influence of aeration on $\mathrm{CH}_{4}, \mathrm{~N}_{2} \mathrm{O}$ and $\mathrm{NH}_{3}$ emissions during aerobic composting of a chicken manure and high $\mathrm{C} / \mathrm{N}$ waste mixture. Waste Management. 31, 33-38. 
Sierra J, Desfontaines L, Faverial J, Loranger-Merciris G, Boval M (2013). Composting and vermicomposting of cattle manure and green wastes under tropical conditions: carbon and nutrient balances and end-product quality. Soil Research. 51, 142-151.

Sommer SG, Dahl P (1999). Nutrient and carbon balance during the composting of deep litter. Journal of Agricultural Engineering Research. 74, 145-153.

Steiner C, Das KC, Melear N, Lakly D (2010). Reducing Nitrogen Loss during Poultry Litter Composting Using Biochar. Journal of Environmental Quality, doi:10.2134/jeq2009.0337

Straathof AL, Chincarini R, Comans RNJ, Hoffland E (2014). Dynamics of soil dissolved organic carbon pools reveal both hydrophobic and hydrophilic compounds sustain microbial respiration. Soil Biology and Biochemistry. 79, 109-116.

Straathof AL, Comans RNJ (2015). Input materials and processing conditions control compost dissolved organic carbon quality. Bioresource Technology. 179:619-23.

Szanto GL, Hamelers HVM, Rulkens WH, Veeken AHM (2007). $\mathrm{NH}_{3}, \mathrm{~N}_{2} \mathrm{O}$ and $\mathrm{CH}_{4}$ emissions during passively aerated composting of straw-rich pig manure. Bioresource Technology. 98(14), 26592670.

Sánchez-Monedero MA, Serramiá N, Civantos CG, Fernández-Hernández A, Roig A (2010). Greenhouse gas emissions during composting of two-phase olive mill wastes with different agroindustrial by-products. Chemosphere. 81, 18-25.

Taeporamaysamai O, Ratanatamskul C (2016). Co-composting of various organic substrates from municipal solid waste using an on-site prototype vermicomposting reactor. International Biodeterioration and Biodegradation. 113, 357 - 366.

Tekalign M, Abiye A, Srivastava KL, Asgelil D. (1993). Improved management of Vertisols for sustainable crop - livestock production in the Ethiopian highlands: Technical Committee of the Joint Vertisol Project, Synthesis report 1986-92. Ethiopia.

Tewodros FD, Sjaastad E, Worku T (2007). Livelihood dependence on urban agriculture in Addis Ababa, Ethiopia. M.Sc. Dissertation. Norwegian University of Life Sciences.

Tittonell P, Vanlauwe B, Leffelaar PA, Rowe EC, Giller KE (2005). Exploring diversity in soil fertility management of smallholder farms in western Kenya: I. Heterogeneity at region and farm scale. Agriculture, Ecosystems \& Environment. 110 (3-4): 149-165.

Tittonell P, Muriuki A, Shepherd KD, Mugendi D, Kaizzi KC, Okeyo J, Verchot L, Coe R, Vanlauwe B (2010). The diversity in rural livelihoods and their influence on soil fertility in agricultural systems of East Africa- A typology of smallholder farms. Agricultural Systems. 103, 83-97.

Tittonell P, Giller KE (2013). When yield gaps are poverty traps: The paradigm of ecological intensification in African smallholder agriculture. Field Crops Research. 143, 76-90.

Tortosa G, Alburquerque AJ, Ait-Baddi G, Cegarra J (2012). The production of commercial organic amendments and fertilisers by composting of two-phase olive mill waste ("alperujo"). Journal of Cleaner Production. 26, 48-55.

United Nation (2014). World Urbanization Prospects. The 2014 revision. Pp 32.

Valbuena D, Tui SH, Erenstein O, Teufel N, Duncan A, Abdoulaye T, Swain B, Mekonen K, Germaine I, Gérard B (2015). Identifying determinants, pressures and trade-offs of crop residue use in mixed smallholder farms in Sub-Saharan Africa and South Asia. Agricultural Systems. 134, 107118.

Van Reewijk LP (1992). Procedures for Soil Analysis (3rd Ed.). International Soil Reference Center (ISRIC), Wageningen, The Netherlands. 
Van Zomeren A, Comans RNJ (2007). Measurement of humic and fulvic acid concentrations and dissolution properties by a rapid batch procedure. Environmental Science and Technology. 41, 6755-6761.

Veenhuizen R, Danso G (2007). Profitability and sustainability of urban and peri-urban agriculture. Agricultural management, marketing and finance occasional paper 19. FAO. Rome, Italy.

Velasco-Velasco J, Parkinson R, Kuri V (2011). Ammonia emissions during vermicomposting of sheep manure. Bioresource Technology. 102, 10959-10964.

Vu DQ, Tran TM, Nguyen PD, Vu CC, Vu TK, Jensen LS (2012). Effect of biogas technology on nutrient flows for small scale and medium scale pig farms in vietnam. Nutrient cycling in Agroecosystem. 94, 1-13.

Vu QD, de Neergaard A, Tran TD, Hoang HTT, Vu VHK, Jensen LS (2015). Greenhouse gas emissions from passive composting of manure and digestate with crop residues and biochar on smallscale livestock farms in Vietnam. Environmental Technology. 36 (23), 2925-2934.

Wang J, Hu Z, Xu X, Jiang X, Zheng B, Liu X, Pan X, Kardol P (2014). Emissions of ammonia and greenhouse gases during combined pre-composting and vermicomposting of duck manure. Waste Management. 34, 1546-1552.

Wei M, Qiu Q, Qian Y, Cheng L, Guo A (2016). Methane oxidation and response of Methylobacter / Methylosarcina methanotrophs in flooded rice soil amended with urea. Applied Soil Ecology. 101, 174-184.

Wichuk K, McCartney D (2010). Compost stability and maturity evaluation - a literature review. Canadian Journal of Civil Engineering. 37, 1505-1523.

Xiao Y, Bai X, Ouyang Z, Zheng H, Xing F (2007). The composition, trend and impact of urban solid waste in Beijing. Environmental Monitoring and Assessment 135 (1-3), 21-30.

Yang F, Li GX, Yang QY, Luo WH (2013). Effect of bulking agents on maturity and gaseous emissions during kitchen waste composting. Chemosphere. 93, 1393-1399.

Zhang M, Heaney D, Henriquez B, Solberg E, Bittner E (2006). A four year study on influence of biosolids/MSW compost application in less productive soils in Alberta: nutrient dynamics. Compost Science and Utilisation. 14, 68-80. 


\section{Summary}

Organic amendments (i.e., crop residues, manure and compost) maintain or increase soil organic matter contents and thereby contribute to enhanced fertiliser use efficiency. Despite the benefits of organic amendments, many smallholder farmers do not retain crop residues and manure on their farmlands. Hence, large amounts of nutrients and carbon are exported from agricultural lands to nearby markets and/or urban areas. At the same time, a large amount of biodegradable waste is produced in cities, and its management has become a major concern in developing countries - where waste management is hardly existing.

My thesis is motivated by the lack of scientific evidence on (i) the socio-economic perspectives of urban-waste composting, (ii) low-cost technologies that improve the agronomic value of urban-waste compost, while reducing losses to the environment and mitigating climate change by reducing greenhouse gas (GHG) emissions. To address these issues, I conducted both socio-economic studies and composting experiments both in laboratory reactors and under field conditions.

In Chapter 1, I provide an overview of previous studies conducted on the use of organic materials (both agricultural and urban waste) for soil amendment, and I list my hypotheses. In Chapter 2, I determined the current use of agricultural waste (i.e., crop residues and manure) under different urban and peri-urban farming systems. This chapter addresses the question Why do farmers retain no or insufficient agricultural waste on their farmlands? I interviewed 220 farmers in Addis Ababa, Ethiopia using standardised semi-structured questionnaires, and found that $85 \%$ of the crop residues were used for animal feed, and $80 \%$ of manure was used for fuel. Less than $10 \%$ of manure and/or crop residues are retained in the soil, indicating that the current use of agricultural residues result in an export of a large amount of nutrients and $C$ from the croplands. Manure is a source of fuel even for urban dwellers. While this demand creates market opportunities and entices farmers to sell their manure (in the form of dung cake) to the nearby cities, it exacerbates carbon and nutrient fluxes from the country side to cities. I noted that farmers with market-oriented production systems allocate their agricultural waste mainly for soil amendment compared to resource-poor subsistence farmers. In addition to this, socio-economic variables such as land ownership, shortage of land and access to extension services influence the farmers' decision to retain agricultural waste on their farmlands. I further expanded Chapter 2 to address the question: If urban waste is composted, is there a demand from (peri-urban) farmers? I assessed the demand for urbanwaste compost (operationalised as farmers willingness to pay and / or to contribute labour for urban-waste compost), and found that $60 \%$ of the farmers were willing to pay and / or to contribute labour for urban-waste composting. Education, distance of the farmland from the city, land tenure status, experience with compost, and access to extension services explained the variation in willingness to pay for or contribute to the 
acquisition of compost. My findings in Chapter 2 indicate that competition for agricultural waste between fuel, feed and soil causes nutrient mining and organic matter losses from agricultural land; hence, urban-waste compost is an alternative option to close this loop. But urban-waste composting cannot be achieved without the involvement of different institutions and needs improvement of the existing policies, infrastructure and financial institutions.

Even though urban-waste compost has been suggested for soil amendment, a large amount of $\mathrm{N}$ losses and GHG emissions occur during composting of N-rich urban waste, which consequently reduce the fertilising value of urban-waste compost and contribute to climate change. The high temperatures during composting are the main drivers for $\mathrm{N}$ losses. Chapter 3 is therefore initiated to evaluate the effectiveness of earthworm composting (vermicomposting) - a mesophilic $\left(<30{ }^{\circ} \mathrm{C}\right)$ composting technique - to reduce $\mathrm{N}$ losses and GHG emissions. I demonstrated that vermicomposting decreased total $\mathrm{N}$ losses by $20 \%$ compared with thermophilic composting. The existing reports on the effect of earthworms on GHG emissions are contradictory. Hence, Chapters 3 used substrates of different quality (as assessed by C:N ratio and the presence of a labile $C$ pool) and manipulated several variables (moisture content and earthworm density) to clarify our understanding on the effect of earthworms on GHG emissions during composting. I noted that earthworms decreased $\mathrm{N}_{2} \mathrm{O}$ emissions during composting, but the earthworms effect varied between substrate quality, earthworm density and feeding ratio. Higher earthworm density increased $\mathrm{N}_{2} \mathrm{O}$ emissions during vermicomposting. My findings suggested that different species of epigeic earthworms could result in different $\mathrm{N}_{2} \mathrm{O}$ emissions. Earthworms decreased $\mathrm{CH}_{4}$ emissions from composting, and this observation was consistently found in all experiments. Earthworms increased $\mathrm{CO}_{2}$ emissions, and this observation was also consistent in all experiments. Higher $\mathrm{CO}_{2}$ evolution indicates a greater degree of stabilisation of the compost, and it should be noted that in the end all composts are likely of similar stability as more $\mathrm{CO}_{2}$ might escape after application of the thermophilic compost to the field. Hence, I decided to exclude $\mathrm{CO}_{2}$ emissions from the total GHG budget. When $\mathrm{CO}_{2}$ emission is excluded from GHG emissions, vermicomposting reduces GHG emissions compared with non-earthworm treatments (thermophilic composting). However, total GHG emissions are higher from vermicomposting than from thermophilic composting when $\mathrm{CO}_{2}$ is included in the balance.

Low levels of $\mathrm{N}$ in urban-waste compost, particularly in (sub-)tropical countries has been observed, which negatively impacts the agronomic value of compost from a soil fertility perspective. Composting of (N-poor) urban waste together with $\mathrm{N}$-rich materials such as manure is commonly used to increase the $\mathrm{N}$ content of the final compost. This practice, however, results in a significant $\mathrm{NH}_{3}$ volatilisation due to the combination of high temperatures during the thermophilic phase and high $\mathrm{NH}_{4}^{+}$concentration in the Nrich substrate. Chapter 4 addresses the question: Does the addition of N-rich substrate after 
the thermophilic phase reduce $N$ losses? I conducted a 90 days composting experiment using N-poor urban waste materials and poultry manure as N-rich substrate. Delayed addition reduced nitrogen losses by $9-20 \%$ compared with traditional composting method. Furthermore, I tested whether delayed addition influences $\mathrm{N}_{2} \mathrm{O}$ and $\mathrm{CH}_{4}$ emissions, and noted that delayed addition increased $\mathrm{N}_{2} \mathrm{O}$ emissions by $400-600 \%$, but decreased $\mathrm{CH}_{4}$ emissions by $50 \%$. In all, delayed addition had only a marginal effect $(\mathrm{P}=0.06)$ on total non- $\mathrm{CO}_{2} \mathrm{GHG}$ emissions. I also confirmed that delayed addition resulted in compost that was as stable and effective at completely eradicating weed seeds as single addition. Hence, I conclude that delayed addition is one option for increasing the fertilising value of urban-waste compost without having a significant effect on total greenhouse gas emissions or compost stability.

Because higher $\mathrm{CO}_{2}$ emissions indicates a higher degree of stabilisation, I initiated Chapter 5 to link the observed effect of earthworms on $\mathrm{CO}_{2}$ emissions with additional and potentially more reliable indices of compost stability such as dissolved organic carbon (DOC) quantity and its composition (humic acid, fulvic acid, hydrophobic neutral, and hydrophilic compounds) - which was a recently proposed indicator of compost stability. Earthworms showed a lowering of the contents of DOC and its various fractions compared with non-earthworm treatments, which is a consequence of higher compost stability. I noted that humic acid fraction was depleted more quickly than the other hydrophobic compounds, confirming that it is degraded during composting. I expanded of Chapter 5 to address the effect of feeding ratio - the ratio of earthworms to the amount of substrate added - on compost stability. The optimum feeding ratio decreased DOC quantity and its composition compared with higher ratio, which confirms higher stability under optimum feeding. My findings indicate that earthworms accelerate the stabilisation of organic materials, and measurement of DOC components provides greater insight about compost stability. Moreover, feeding ratio should be considered when assessing the effect of earthworms on stabilisation of biodegradable waste. In the general discussion (Chapter 6), I synthesised my findings and emphasised on the challenges to increase soil fertility and sustain crop production in developing countries, and the opportunities to utilise urban-waste as soil amendment. Recommendations for future research directions were also included in this chapter. Finally, I suggested that biodegradable urban waste should be considered as alternative source for soil amendment. Technologies such as vermicomposting and delayed addition of N-rich substrate are recommended to reduce $\mathrm{N}$ losses and mitigate GHG emissions. 


\section{Sammenfatning}

Organiske jordforbedringsmidler (f.eks. afgrøderester, husdyrgødning og kompost) opretholder eller øger jordens indhold af organisk stof og medvirker hermed til at en øget udnyttelseseffektivitet af gødning. På trods af fordelene ved de organiske jordforbedringsmidler fastholder mange husmænd ikke afgrøderester og husdyrgødning på deres marker. Dermed bliver store mængder af næring og kulstof eksporteret fra landbrugsområder til nærliggende markeder og/eller byområder. Samtidig bliver der produceret store mænger biologisk nedbrydeligt affald i byerne og håndteringen af dette affald er blevet et betydeligt problem in udviklingslande - hvor affaldshåndtering er så godt som ikke-eksisterende.

Min afhandling er motiveret af fraværet af videnskabelig evidens vedrørende (i) de socio-økonomiske perspektiver af kompostering af byaffald, (ii) billige teknologier der forbedrer den agronomiske værdi af byaffaldskompost samtidig med at de kan reducere tabet til miljøet og afbøde klimaforandring gennem en reduktion af udledning af drivhusgasser (GHG). For at adressere disse spørgsmål udførte jeg både socioøkonomiske studier og komposteringsforsøg - både i laboratorieskala og under markforhold.

I Kapitel 1 giver jeg et overblik over tidligere studier af brugen af organiske restprodukter (både fra landbruget og i form af byaffald) som jordforbedringsmiddel og jeg oplister mine hypoteser. I Kapitel 2 undersøger jeg den nuværende anvendelse af landbrugsaffald (afgrøderester og husdyrgødning) i forskellige landbrugssystemer i byer og bynære områder. Dette kapitel adresserer spørgsmålet Hvorfor sker det kun i utilstrækkelig grad eller slet ikke, at bønder fastholder landbrugsaffald på deres jord? Jeg interviewede 220 bønder i Addis Ababa, Etiopien vha. standardiserede, semistrukturerede spørgeskemaer og fandt, at $85 \%$ af afgrøderesterne blev anvendt til dyrefoder og at $80 \%$ af husdyrgødningen blev anvendt til brændsel. Mindre end $10 \%$ af husdyrgødningen og/eller afgrøderesterne blev fasthold i jorden hvilket indikerer at den nuværenden anvendelse af landbrugsrestprodukter resulterer i en eksport af store mængder af næringsstoffer og kulstof fra de dyrkede arealer. Husdyrgødning er en kilde til brændsel selv for byboere. Mens denne efterspørgsel medfører handelsmuligheder og ansporer bønder til at sælge deres husdyrgødning (i form af møgkager) til de nærliggende byer, forstærker denne efterspørgsel også transporten af kulstof of næringsstoffer fra landet til byerne. Jeg noterede mig, at landbrugere med markedsorienterede produktionssystemer primært allokerer deres langbrugsaffald til jordtilsætning i sammenligning med ressourcesvage subsistenslandbrugere. Derudover påvirker socioøkonomiske faktorer såsom ejerskab til jord, knaphed på jord og adgang til rådgivningstjenester langbrugernes beslutning om at fastholde langbrugsaffald på deres 
jord. I kapitel 2 adresserede jeg endvidere spørgsmålet: Hvis byaffald bliver komposteret, er der så en efterspørgsel fra (bynære) landbrugere? Jeg vurderede efterspørgslen efter byaffaldskompost (operationaliseret som landbrugernes villighed til at betale og/eller til at bidrage med arbejdskraft i bytte for byaffaldskompost) og fandt at $60 \%$ af landbrugerne var villige til at betale og/eller bidrage med arbejdskraft til kompostering af byaffald. Uddannelse, afstand fra markerne til byen, ejendomsretten til jorden, erfaring med kompost og adgang til rådgivning forklarede variationen $\mathrm{i}$ villigheden til at betale for eller bidrage til erhvervelsen kompost. Mine fund i kapitel 2 indikerer at konkurrence om landbrugsaffald mellem brændsel, foder og jorden medfører udpining og tab af organisk stof i landbrugsjorderne; deraf følger det, at byaffaldskompost udgør et alternativ mulighed for at lukke denne løkke. Men kompostering af byaffald kan ikke opnås uden involvering af forskellige institutioner og afhænger af forbedringer af eksisterende politikker, infrastruktur og finansielle institutioner.

Selvom kompost lavet af byaffald er blevet foreslået som jordforbedringsmiddel sker der et stort tab af $\mathrm{N}$ og emission af drivhusgasser under komposteringen af $\mathrm{N}$-rigt byaffald hvilket igen fører til en reduktion i gødningsværdien af byaffaldskomposten og medvirker til klimaforandringer. De høje temperaturer under kompostering en den primære drivkraft bag N-tabet. Derfor undersøger jeg i Kapitel 3 potentialet af kompostering vha. regnorme (ormekompostering) - en mesofil $\left(<30^{\circ} \mathrm{C}\right.$ ) komposteringsteknik - til at reducere kvælstoftab og emissioner af drivhusgasser. Jeg demonstrerede at ormekompostering nedsatte det totale kvælstoftab med 20\% sammenlignet med termofil kompostering. De eksisterende studier af effekten af regnorme på drivhusgasudledninger er modstridende. For at øge vores forståelse af effekten af regnorme på udledningerne af drivhusgasser anvendte jeg derfor i Kapitel 3 substrater af forskellig kvalitet (bedømt ud fra C:N ratio og tilstedeværelsen af en letnedbrydelig C pulje) og manipulerede forskellige variable (vandindhold og tætheden af regnorme). Jeg observerede at regnormene sænkede $\mathrm{N}_{2} \mathrm{O}$-udledningerne under kompostering, men effekten af regnorme varierede afhængig af substratkvalitet, tæthed af regnorme og forholdet mellem regnorme og foder (fodringsforholdet). En øgning i regnormstætheden medførte en øgning i $\mathrm{N}_{2} \mathrm{O}$-emmisionerne under ormekompostering. Mine resultater antyder, at forskellige arter af epigæiske regnorme kan medføre forskellige niveauer af $\mathrm{N}_{2} \mathrm{O}$-emmission. Regnorme førte til et fald i CH4-udledningen fra kompostering og denne observation var konsistent på tværs af alle udførte forsøg. Regnorme øgede $\mathrm{CO}_{2}$-emmisionerne og denne observation var også konsistent på tværs af alle udførte forsøg. En højere $\mathrm{CO}_{2}$-udledning indikerer en højere grad af stabilisering af komposten, og det bør noteres, at det må forventes at alle kompost-typer i sidste ende sandsynligvis har en lignende stabilitet idet mere $\mathrm{CO}_{2}$ kan tænkes at blive frigivet efter udbringning af den termofile kompost på marken. Derfor besluttede jeg mig for at udelade $\mathrm{CO}_{2}$ fra det samlede drivhusgasbudget. Når $\mathrm{CO}_{2}$-udledningerne udelades fra 
drivhusgasudledningerne, medfører ormekompostering en reduktion den totale udledning af drivhusgasser $\mathrm{i}$ sammenligning med den termofile kompostering. Imidlertid er den totale udledning af drivhusgasser højere fra ormekompostering end fra termofil kompostering når $\mathrm{CO} 2$ inkluderes i regnestykket.

Lave kvælstofniveauer i byaffaldskompost, som især er blevet observeret (subtropiske lande, påvirker den agronomiske værdi af komposten i negativ retning. Kompostering af (N-fattigt) byaffald sammen med N-rige materialer såsom husdyrgødning er en ofte anvendt teknik til at øge N-indholdet i den færdige kompost. Denne praksis medfører dog også en betragtelig NH3-fordampning på grund af kombinationen af de høje temperaturer i den termofile fase og høje NH4+koncentrationer $\mathrm{i}$ det N-rige substrat. Kapitel 4 adresserer spørgsmålet: Fører en forsinkelse i tilsætningen af det $\mathrm{N}$-rige substrat til efter den termofile fase til en reduktion i kvælstoftabene? Jeg udførte et 90 dage langt komposteringsforsøg med N-fattige byaffaldsprodukter og N-rigt kyllingemøg. En forsinket tilsætning af kyllingemøget reducerede kvælstoftabene med 9-20\% sammenlignet med den traditionelle komposteringsmetode. Endvidere testede jeg hvorvidt forsinket tilsætning påvirkede udledningerne af $\mathrm{N}_{2} \mathrm{O}$ og $\mathrm{CH}_{4}$, og noterede at forsinket tilsætning øgede $\mathrm{N} 2 \mathrm{O}-$ udledningerne med 400-600\%, men sænkede CH4-udledningerne med 50\%. Alt $\mathrm{i}$ alt havde forsinket tilsætning kun en marginal effekt $(P=0,06)$ på udledningerne af drivhusgasser fraregnet $\mathrm{CO}$ 2. Jeg bekræftede, at forsinket tilsætning var lige så effektiv til at udrydde ukrudtsfrø og resulterede i en kompost der var lige så stabil og effektiv som den traditionelle metode med en enkelt tilsætning. Jeg konkluderer derfor at forsinket tilsætning giver mulighed for at øge gødningsværdien af byaffaldskompost uden at have en signifikant effekt på de totale udledninger af drivhusgasser eller stabiliteten af komposten.

Idet en højere CO2-udledning indikerer en højere grad af stabilisering påbegyndte jeg kapitel 5 for at linke de observerede effekter af regnorme på CO2-udleningerne til supplerende og potentielt mere pålidelige tal for kompoststabilitet såsom mængden af opløst organisk kulstof (DOC), og dettes sammensætning (humussyre, fulvussyre, hydrofobe neutrale og hydrofile stoffer), som for nylig er blevet foreslået som indikator for kompoststabilitet. Jeg noterede mig, at humussyrefraktionen blev udtømt hurtigere end de øvrige hydrofobe stoffer, hvilket bekræfter at den nedbrydes under kompostering. Jeg gik videre i kapitel 5 for at adressere effekten af fodringsforholdet på stabiliteten af kompost. Det optimale forhold sænkede mængden af DOC og medførte en ændring i sammensætningen af DOC i sammenligning med et højere forhold. Mine resultater indikerer at regnorme accelerer stabiliseringen af de organiske materialer og at målinger af DOC-komponenter giver større indsigt vedrørende kompoststabilitet. Endvidere bør fodringsforholdet tages med i betragtning, når man undersøger effekten af regnorme på stabilisering af biologisk nedbrydeligt materiale. 
I den generelle diskussion (kapitel 6) syntetiserede jeg mine resultater og fremhævede de udfordringer der er i forbindelse med at øge jordfrugtbarhed og opretbolde afgrødeproduktion i udviklingslande og de muligheder der eksisterer for at anvende byaffald som et jordforbedringsmiddel. Anbefalinger til fremtidig forskning blev også inkluderet i dette kapitel. Endelig foreslog jeg, at biologisk nedbrydeligt byaffald burde blive anset for at være et alternativ som jordforbedringsmiddel. Teknologier såsom ormekompostering og forsinket tilsætning af N-rige substrater anbefales for at reducere N-tab og afbøde drivhusgasudledninger. 


\section{Acknowledgments}

I started this long journey somewhat more than four years ago. During this period, I acquired new skills and knowledge on how to do science in multicultural and multidisciplinary settings. This journey has now come to an end. Hence I would like to acknowledge people and institutions who helped me to write this new chapter of my life with a colorful ink.

First of all, I am greatly indebted to my promoters Prof. Andreas de Neergaard (Copenhagen University) and Prof. Thomas Kuyper (Wageningen University) and my co-promoter Dr. Sander Bruun (Copenhagen University). Dear all, I thank you very much for believing in me and allowing me to be your student. You helped me to focus on mechanistic studies and scientific writing, and rebuilt me to an independent person who enjoys scientific challenges. I really appreciate what we discussed as a scientist and colleague. I am fortunate to have a supervisory team who understand and tolerate the PhD's academic difficulties, personal life and cultural shocks. I also thank you for challenging me with my own experimentations and results. I learned a lot from them. Your constructive comments on this thesis as well as on my personal character are indispensable, and lifted me to a better position as a scientist. Your doors were always open, and made me feel welcome. "Veel dank" Prof. Thom. "Mange tak" Prof. Andreas and Dr. Sander.

In addition to my supervisory team, many people and institutions contributed towards the success of this journey. I would like to thank the EACEA (Education, Audiovisual and Culture Executive Agency) of the European Commission - the Agricultural Transformation by Innovation (AgTrain) Erasmus Mundus Joint Doctorate Programme for funding the project. My special thanks also go to Prof. Lijbert Brussaard for accepting me for this position and for his kind support, guidance and invaluable comments on my proposal. I would also thank prof. Rob Comans for helpful discussion on DOC fractionation and the interpretation of the various fractions. I am grateful to Mr. Lou Derks from De Polderworm for his interest in my project, technical advice and providing the earthworms for free.

My gratitude goes to Mr. Morten Læssøe Stephensen (Copenhagen University), Jaap Nelemans (Wageningen University) and Tamas Salanki (Wageningen University) for their technical supports during the laboratory work. The kindhearted help of Biruk Yadessa, Gebremedhin Ambaw and Mikiyas Ahmed during the field work is highly appreciated. The project would not bear fruit without your support. I would like to acknowledge Lisbeth Axelsen (Copenhagen University) and Marnella van der Tol (Wageningen University) for your support in all administrative issues, particularly during the visa process. Your smile always made me feel home. 
Syed and Niharika, I cannot thank you enough for being the best friends while I was at Copenhagen. You always motivated me to move forward. I enjoyed the time we spent together during holidays, birthdays, at Roskilde (Denmark). Syed, I also thank you for being my paranymph without even knowing what it was. আभনাকে অনেক ধন্যবাদ. The AgTraIn was a great opportunity for me to meet other $\mathrm{PhD}$ candidates from different disciplines and broaden my expertise. I therefore would like to acknowledge all the AgTraIn family (the passionate, intelligent and industrious $\mathrm{PhD}$ candidates and graduates) for your constructive discussions and inspiration. I learned a lot from you guys. Ali, Zeinu, Awol and Nesredhin - my Ethiopian fellows at Copenhagen University - thank you very much for your encouragement and critical comments on my work. I would also thank you for taking care of my family in my absence. My colleagues from Copenhagen University, I appreciate your endless support. I cultivate a lot of knowledge from our weekly presentations. I also enjoyed the brainstorming discussions that we had about science and life in general. "Mange tak" guys.

I could manage to meet few people in Wageningen University even though I stayed only for one year and spent most of my time in the laboratory and/or office. Rima, Yong, Janna, Joana, Giulia, Ingrid, Ros and my other colleagues at Wageningen University, I am extremely grateful for the chat that we had at different occasions. Rima, I also thank you for being my paranymph without any hesitation. Ana de Mota, thank you very much for your interest to do your M.Sc project with me. I really enjoyed and learned a lot from the work we did together. Muito obrigado. I am greatly indebted to my friend Habtamu and his wife Selam for their kind thoughts and warm invitation to their home whenever I missed injera. I feel home away from home because of you, guys. I owe you one.

Goytom, Afita, Alula, Abi, Zerhiun and Jose - my fellow Ethiopian students at Wageningen - I thank you very much for accompanying me to the library (Forum) and staying there until 23:00hrs every weekday. Your helped me to finish my PhD before my contract ends. I will really miss you guys. Of course, I already miss the security announcement "attention (Alula, Goytom) you're kindly requested to leave the building immediately". I always remember the humors, cooks (the chicken) and drinks. Even though it is still difficult for me to believe that he is gone, I thank my friend Endalkachew Kissi for encouraged me to apply for the AgTraIn program before four years ago. I will always remember the crazy things we did together. Too young to die my dear! May God rest your soul in peace!

The last but not the least, my gratitude goes to my family for their tolerance during my absences, endless love and emotional support. I would like to thank my wife - Birtukan Seid Muhe - for her patience and taking care of me during many difficult times. Your tolerances prove that your love for me is unreserved. Firdos (mama) - my little one - thank you very much for not crying when I was away from home. Daddy is 
home now and no more Skype. Gashye - my dad - I wish that you could see that your little one receives a $\mathrm{PhD}$ degree. You were always with me when life took me to an unexpected path. You were the one who re-engineer my life and guided me through the new journey. You taught me what a father should do for his children. Gashye, your guiding hand on my shoulder will remain with me forever. May God rest your soul in peace! Tete - my mom - I am glad because you witnessed the accomplishment of my PhD. Teteye, I thank you very much for your prayers and to be with Gashye to have redesigned my life and guided me through the new paths. I wish you Methuselah's age.

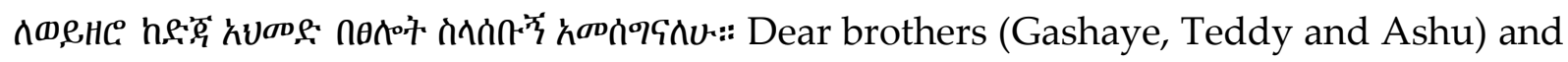
sisters (Temebet, Mesye, Temodsh and Yemi), I thank you very much for your prayers and support throughout this journey. I love you so much. Nephews, Aunties, Uncles, Cousins and families, I appreciate your unreserved love. h.

Abebe 


\begin{abstract}
About the author
Abebe Nigussie Nigatu was born on the $6^{\text {th }}$ of April 1982 in Addis Ababa, Ethiopia. He completed his high-school education in 2000, and joined Haromaya University

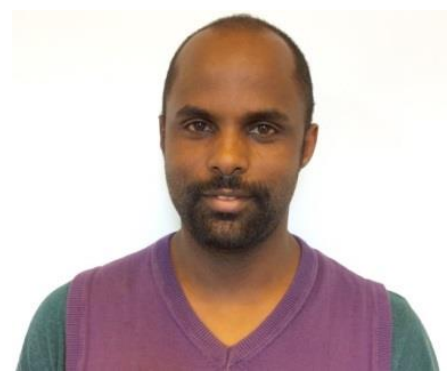
(Ethiopia), then Alemaya University, to pursue his education in agricultural sciences. He received his Bachelor degree in Plant Sciences in July 2004. While doing a project for his B.Sc degree on "the pedological characteristics of soils along different land types", he had a keen interest in soil biogeochemistry and fertility. Soon after his graduation, he decided to continue his postgraduate study and received M.Sc degree in soil science from the same university in July 2006. His M.Sc thesis was on "the contribution of indigenous tree species for soil fertility". After his graduation he worked at Ethiopian Institute of Agricultural Research (EIAR), Mizan-tepi University (Ethiopia) and Jimma University (Ethiopia).

In 2012, he was awarded an Erasmus mundus Joint Doctorate Programme Agricultural Transformation by Innovation (AgTraIn) and started his PhD study at Wageningen and Copenhagen Universities. He was based at Copenhagen University in the first three years, and moved to Wageningen in 2015 to finalise his thesis.
\end{abstract}




\section{List of publications}

Nigussie, A., Kuyper, TW., Bruun, S., de Neergaard A. (2017). Delayed addition of nitrogenrich substrates during composting of municipal waste: Effects on nitrogen loss, greenhouse gas emissions and compost stability. Chemosphere 166: $352-362$.

Nigussie, A., Kuyper, TW., Bruun, S., de Neergaard A. (2016). Vermicomposting as a technology for reducing nitrogen losses and greenhouse gas emissions from small-scale composting. Journal of Cleaner Production. 139, 429-439.

Zwetsloot, MJ., Lehmann, J., Bauerle, T., Vanek, S., Hestrin, R., Nigussie, A. (2016). Phosphorus availability from bone char in a P-fixing soil influenced by root-mycorrhizaebiochar interactions. Plant and Soil, 408:95-105.

Nigussie, A., Kuyper, T.W., de Neergaard, A. (2015). Agricultural waste utilisation strategies and demand for urban-waste compost: Evidence from smallholder farmers in Ethiopia. Waste Management. 44, 82 - 93.

Getahun, T., Nigussie, A., Entele, T., Van Gerven, T., Van der Bruggen, B., (2012). Effect of turning frequencies on composting of biodegradable municipal soil waste quality. Resources, Conservation and Recycling, 65, 79-84.

\section{Submitted articles}

Nigussie, A., Bruun, S., de Neergaard, A., Kuyper, TW. Earthworms change the quantity and composition of dissolved organic carbon and reduce greenhouse gas emissions during composting. Submitted to Waste Management

Bryndum, S., Muschler, R., Nigussie, A., Magid, J., de Neergaard, A. Nitrogenfertilizing value of compost from sugarcane bagasse and filter cake - Effects of turning frequency, time of poultry manure addition and placement in soil. Submitted to Waste Management 
With the training and education activities listed below the PhD candidate has complied with the requirements set by the C.T. de Wit Graduate School for Production Ecology and Resource Conservation (PE\&RC) which comprises of a minimum total of 32 ECTS ( $=22$ weeks of activities)

\section{Review of literature (6 ECTS)}

- Recycling of urban waste for local vegetable production

\section{Writing of project proposal (4.5 ECTS)}

- Recycling of urban waste for local vegetable production

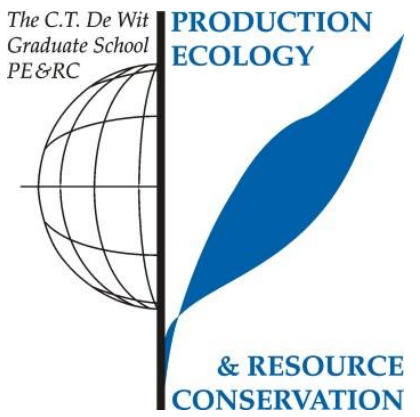

\section{Post-graduate courses (18 ECTS)}

Plant nutrients cycling in terrestrial ecosystems; Copenhagen University (2013)

sotope methods for nutrient carbon dynamics; Copenhagen University (2013)

Joint field course on qualitative analysis; Copenhagen University (2013)

\section{Invited review of (unpublished) journal manuscript (1 ECTS)}

Global Research Journal of Agricultural and Biological Sciences: mushroom consumption habits of Wacha Kebele inhabitants, southwestern Ethiopia (2012)

\section{Competence strengthening / skills courses (9.5 ECTS)}

Academic writing; Copenhagen University (2012)

Presentation techniques; Copenhagen University (2014)

Applied research communication and dissemination for agricultural development; Copenhagen University (2014)

Project management; Copenhagen University (2015)

Responsible conduct research; Copenhagen University (2016)

PE\&RC Annual meetings, seminars and the PE\&RC weekend (1.2 ECTS)

PE\&RC Mid-term weekend (2015)

PE\&RC Day: one's waste...another's treasures? (2015)

\section{Discussion groups / local seminars / other scientific meetings (6.5 ECTS)}

Soil and waste group scientific meetings; Copenhagen University (2012-2015)

Agricultural transformation by innovation scientific meetings (2015-2016)

\section{International symposia, workshops and conferences (6 ECTS)}

- Tropentag: bridging the gap between increasing knowledge and decreasing resources; Prague, Czech Republic (2014)

The $16^{\text {th }}$ RAMIRAN conference: rural - urban symbiosis; Hamburg, Germany (2015)

- $\quad$ The $30^{\text {st }}$ international conference on solid waste management; Philadelphia, USA (2015)

\section{Lecturing / supervision of practicals / tutorials (3 ECTS)}

Tropical crop production (2014)

Tropical crop production (2015)

Sustainable land management (2015)

Sustainable agricultural development pathways (2015)

\section{Supervision of a MSc student (3 ECTS)}

Delayed addition N-rich substrate affects GHG emissions during composting; Wageningen University Waste marketing in Malawi; Copenhagen University 


\section{Funding}

This study was financially supported by the Agricultural Transformation by Innovation (AgTraIn) Erasmus Mundus Joint Doctorate Programme, funded by the EACEA (Education, Audio-visual and Culture Executive Agency) of the European Commission. 